\title{
Chemoselective Oxidation of $p$-Methoxybenzyl ethers by an Electronically Tuned Nitroxyl Radical Catalyst
}

Shohei Hamada, ${ }^{* \dagger}$ Koichi Sugimoto, ${ }^{\dagger}$ Elghareeb E. Elboray, ${ }^{\dagger \dagger}{ }^{\dagger}$ Takeo Kawabata, ${ }^{\S}$ and Takumi Furuta $^{\dagger}$

†Department of Pharmaceutical Chemistry, Kyoto Pharmaceutical University, Yamashina-ku, Kyoto 607-8414, Japan

Department of Chemistry, Faculty of Science, South Valley University, Qena, Egypt

${ }^{\S}$ Institute for Chemical Research, Kyoto University, Uji, Kyoto 611-0011, Japan

E-mail: hamada@mb.kyoto-phu.ac.jp

\section{Supporting Information}

Content:

General

Oxidative deprotection of the benzyl groups by 1 /PIFA system

Mechanistic studies for the oxidation of benzylic ethers

General procedure for oxidative deprotection of benzylic groups by nitroxyl radicals (Table 1)

General procedures for oxidative deprotection of PMB groups by 1/PIFA (Scheme 2)

Deprotection of PMB-protected benzyl alcohol (2h) without addition of water

General procedure for direct synthesis of ketones and aldehydes from

PMB-protected alcohols by 1/PIFA (Scheme 3)

Synthesis of the substates 


\section{General}

NMR spectra were obtained with a Bruker Ascend 500 spectrometer $(500 \mathrm{MHz})$, or a Bruker UltraShield 300 spectrometer $(300 \mathrm{MHz})$, with chemical shift being given in ppm units ( ${ }^{1} \mathrm{H} \mathrm{NMR}$ in $\mathrm{CDCl}_{3}: \mathrm{CHCl}_{3}$ as an internal

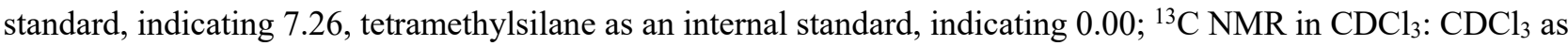
internal standards, indicating 77.1). Spin-spin coupling constants were given in $\mathrm{Hz}$ units. IR spectra were recorded with a JASCO FT-IR4600 Spectrometer. HRMS were recorded with a JEOL GCmate II (for EI), or a Shimadzu LSMS-IT-TOF (for ESI). Silica gel column chromatography was carried out by using Silica gel $60 \mathrm{~N}$ (spherical, neutral, 63 210 $\mu \mathrm{m}$, Kanto Chemical Co., Inc.). Medium pressure liquid chromatography (MPLC) was performed using YAMAZEN W-Prep 2XY equipped with Chromatorex (Fuji Silysia Chemical Ltd.). TLC analysis and preparative TLC were performed on commercial glass plates coated with a $0.25 \mathrm{~mm}$ and a $0.5 \mathrm{~mm}$ layers, respectively, of Merck Kiesel-gel $60 \mathrm{~F}_{254}$. All chemicals and reagents were commercially purchased and used without further purification. All reactions that required heating were conducted on hot plates with the appropriately sized heating blocks, and the temperature of the heating blocks was monitored by heating probe.

\section{Oxidative deprotection of benzyl groups by 1/PIFA system}

Scheme S1. Oxidative deprotection of Bn groups by 1/PIFA.

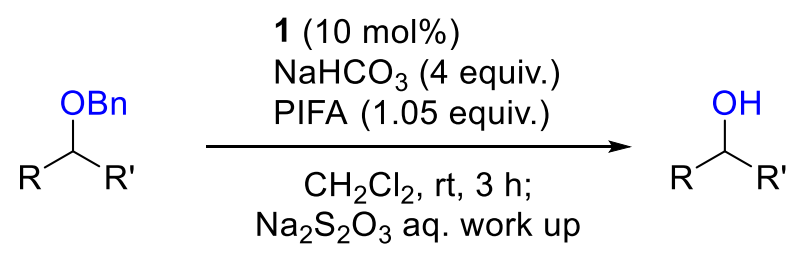

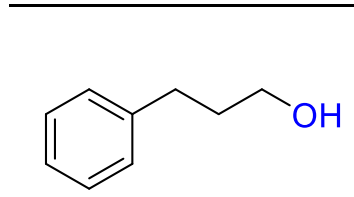

3a, $94 \%$

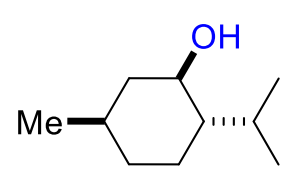

$3 \mathbf{e}, 68 \%$<smiles>CC(C)(C)C(O)c1ccccc1</smiles>

$3 \mathbf{j}, 60 \%^{b}$

${ }^{a}$ Yields were determined by ${ }^{1} \mathrm{H}$ NMR analysis of the crude reaction residue using 1,3,5-trimethoxybenzene as the internal standard. ${ }^{b} 2$ equiv. of $\mathrm{H}_{2} \mathrm{O}$ was added.

To a mixture of benzyl ether $(0.100 \mathrm{mmol}), 1(10 \mu \mathrm{mol})$, and $\mathrm{NaHCO}_{3}(33.6 \mathrm{mg}, 0.400 \mathrm{mmol})$ in $\mathrm{DCM}(2.0 \mathrm{~mL})$ was added PIFA (45.2 mg, $0.105 \mathrm{mmol}$ ). The resulting mixture was stirred at room temperature for $3 \mathrm{~h}$. The reaction was quenched with saturated aq. $\mathrm{Na}_{2} \mathrm{~S}_{2} \mathrm{O}_{3}$ and extracted with $\mathrm{CHCl}_{3}$. The organic layer was separated, dried over $\mathrm{Na}_{2} \mathrm{SO}_{4}$, filtered, and concentrated in vacuo to give the crude product. The yield of $\mathbf{3 a},{ }^{1} \mathbf{3 e},{ }^{2}$ and $\mathbf{3} \mathbf{j}^{3}$ were determined by ${ }^{1} \mathrm{H}$ NMR of the crude mixture with 1,3,5-trimethoxybenzene as an internal standard. 


\section{Mechanistic studies for the oxidation of benzylic ethers}

We investigated the mechanistic aspects of the oxidation of the benzylic ethers. The kinetic isotope effect of the oxidative deprotection of benzyl ether 5 using the 1/PIFA system was examined under pseudo-first-order conditions $\left(k_{\mathrm{H}} / k_{\mathrm{D}}=3.6\right.$, Figure S1). Subsequently, the Hammett plot of the oxidative debenzylation of para- or metasubstituted benzylic ethers by 1 was generated (Figure S2). A linear relationship was observed between $\log \left(k_{\mathrm{X}} / k_{\mathrm{H}}\right)$ and the $\sigma$ constants of the substituents, with a reaction constant of $\rho=-2.7$. This large negative reaction constant indicates that the benzylic position is positively charged in the transition state during the oxidation of the benzylic ethers. Accordingly, the oxidation of benzylic ethers and alcohols by the 1/PIFA system can be expected to proceed via a rate-determining hydride transfer from the $\alpha$-hydrogen to the oxygen.

Figure S1. Kinetic isotope effect with benzylic ether $\mathbf{5}$ in the presence of catalyst $\mathbf{1}$

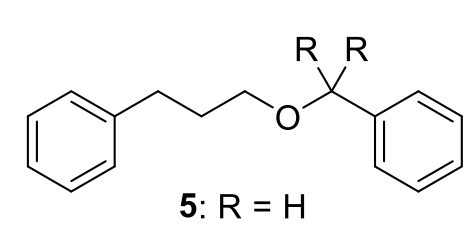

5-D: $R=D$

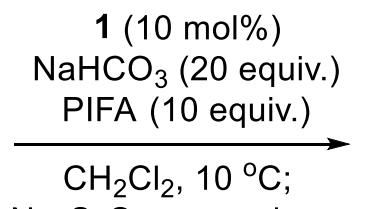

$\mathrm{Na}_{2} \mathrm{~S}_{2} \mathrm{O}_{3}$ aq. work up

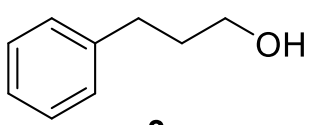

3a

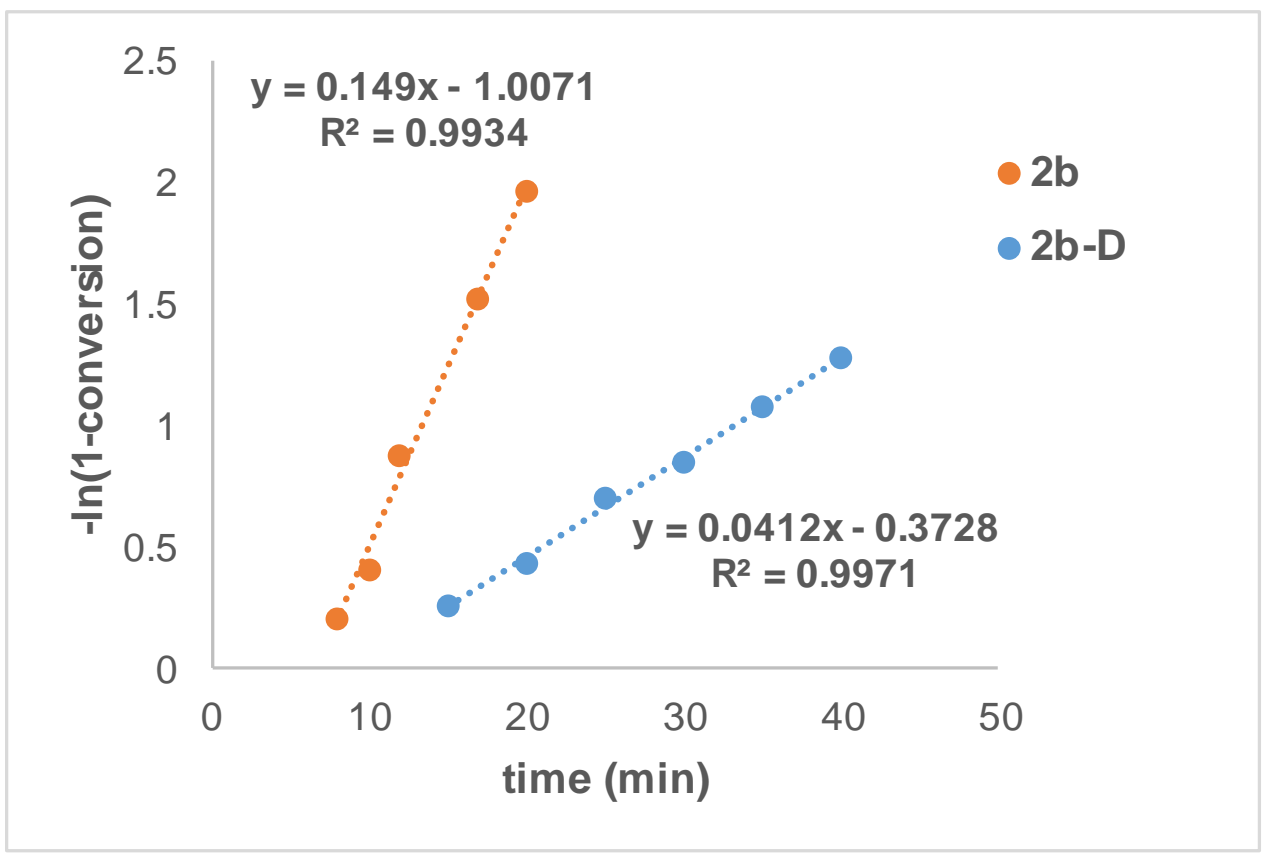

Procedure for evaluation of the kinetic isotope effect with benzylic ether 5 in the presence of catalyst 1

To 5 sets of the mixtures of $\mathbf{5}(11.3 \mathrm{mg}, 50.0 \mu \mathrm{mol}), \mathbf{1}(1.2 \mathrm{mg}, 5.2 \mu \mathrm{mol})$ and $\mathrm{NaHCO}_{3}(84.0 \mathrm{mg}, 1.00 \mathrm{mmol})$ in DCM $(1.0 \mathrm{~mL})$ were added PIFA $(215 \mathrm{mg}, 0.500 \mathrm{mmol})$ at $10{ }^{\circ} \mathrm{C}$. The resulting mixtures were stirred at $10{ }^{\circ} \mathrm{C}$ and quenched with saturated aq. $\mathrm{Na}_{2} \mathrm{~S}_{2} \mathrm{O}_{3}$ at $8,10,12,17$ and $20 \mathrm{~min}$ after starting the reaction. Then the mixture was extracted with $\mathrm{CHCl}_{3}$ and the organic layer was dried over $\mathrm{Na}_{2} \mathrm{SO}_{4}$, filtered and concentrated in vacuo to give the crude product. The yields of $\mathbf{3} \mathbf{a}^{1}$ were determined by ${ }^{1} \mathrm{H}$ NMR of the residue with 1,3,5-trimethoxybenzene as the internal standard. The kinetic study with deuterio-5b (5b-D, $>99 \%$ deuterated) was performed under the same 
conditions as described above with 15, 20, 25, 30, 35, and 40 min reaction periods. From these kinetic studies, the rate constants for $\mathbf{5 b}\left(1.5 \times 10^{-1} \mathrm{~min}^{-1}\right)$ and $\mathbf{5 b}$-D $\left(4.1 \times 10^{-2} \mathrm{~min}^{-1} ; k_{\mathrm{H}} / k_{\mathrm{D}}=3.6\right)$ were obtained.

Scheme S2. Competitive oxidation of benzyl ether 5 and $p$ - or $m$-substituted benzyl ethers.

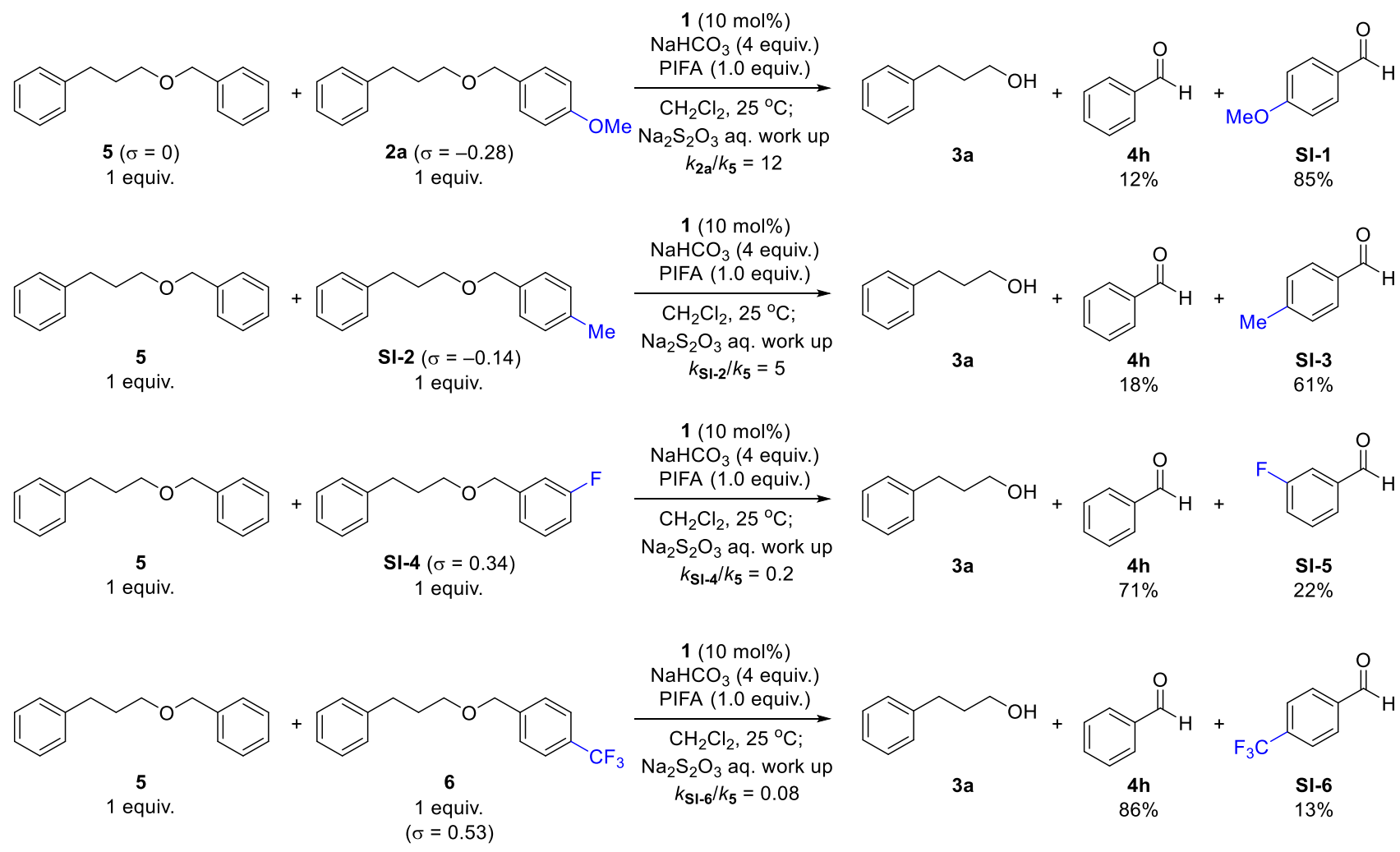

Figure S2. Hammett plot for the oxidative deprotection of benzylic ethers using the 1/PIFA system

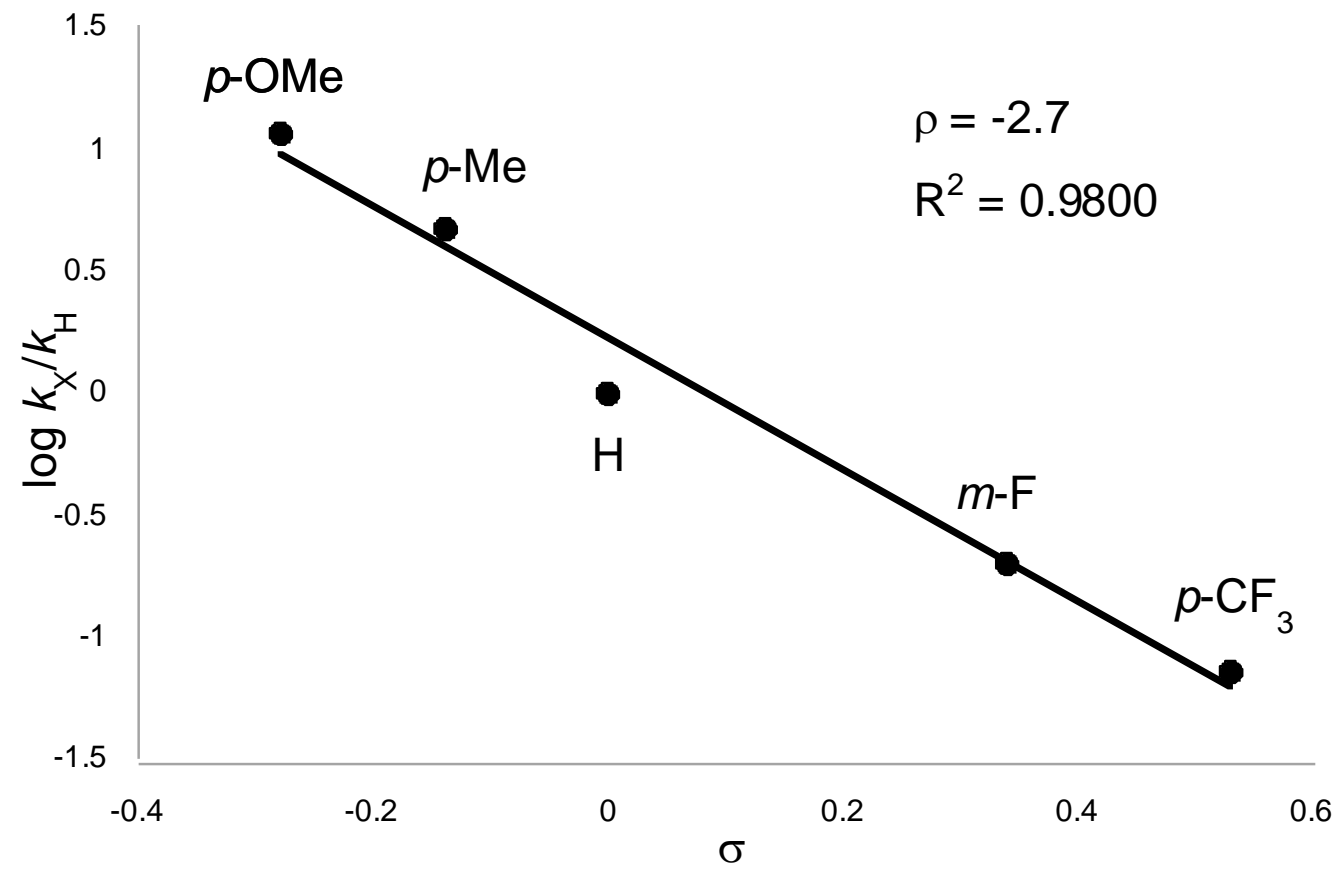




\section{Procedure for Hammett plot for the oxidative deprotection of benzylic ethers using the 1/PIFA system}

Relative rates of $p$-OMe (2a), $p$-Me (SI-2), $m-\mathrm{F}(\mathbf{S I}-\mathbf{4})$, and $p-\mathrm{CF}_{3}(\mathbf{6})$ substituted benzyl ethers toward benzyl ether 5 without substituents were evaluated by the competitive oxidation described in Scheme S2.

To an equimolar mixture of $\mathbf{5}(24.4 \mathrm{mg}, 0.100 \mathrm{mmol})$ and $\mathbf{2 a}, \mathbf{S I - 2}, \mathbf{S I - 4}$, or $\mathbf{6}(0.100 \mathrm{mmol}), \mathbf{1}(2.3 \mathrm{mg}, 10 \mu \mathrm{mol})$ and $\mathrm{NaHCO}_{3}(33.6 \mathrm{mg}, 0.400 \mathrm{mmol})$ in DCM $(2.0 \mathrm{~mL})$ were added PIFA $(43.0 \mathrm{mg}, 0.100 \mathrm{mmol})$. The resulting mixture was stirred at $25^{\circ} \mathrm{C}$ for $3 \mathrm{~h}$. The reaction was quenched with saturated aq. $\mathrm{Na}_{2} \mathrm{~S}_{2} \mathrm{O}_{3}$ and extracted with $\mathrm{CHCl}_{3}$. The organic layer was dried over $\mathrm{Na}_{2} \mathrm{SO}_{4}$, filtered and concentrated in vacuo to give the crude product. The yields of the aldehydes and selectivity were determined by ${ }^{1} \mathrm{H}$ NMR with 1,3,5-trimethoxybenzene as an internal standard.

The structures of the aldehydes, $4 \mathbf{h},{ }^{4}$ SI-1, ${ }^{4}$ SI-3,,${ }^{5}$ SI-5, ${ }^{6}$ and SI-6 ${ }^{7}$ were confirmed by the ${ }^{1} \mathrm{H}$ NMR data reported in the references.

\section{General procedure for oxidative deprotection of benzylic groups by nitroxyl radicals (Table 1)}

To a mixture of the benzylic ether $(0.100 \mathrm{mmol})$, catalyst $(10 \mu \mathrm{mol})$, and $\mathrm{NaHCO}_{3}(33.6 \mathrm{mg}, 0.400 \mathrm{mmol})$ in DCM $(2.0 \mathrm{~mL})$ was added PIFA $(45.2 \mathrm{mg}, 0.105 \mathrm{mmol})$. The resulting mixture was stirred at room temperature for $3 \mathrm{~h}$. The reaction was quenched with saturated aq. $\mathrm{Na}_{2} \mathrm{~S}_{2} \mathrm{O}_{3}$ and extracted with $\mathrm{CHCl}_{3}$. The organic layer was dried over $\mathrm{Na}_{2} \mathrm{SO}_{4}$, filtered and concentrated in vacuo to give the crude product. The yield of $\mathbf{3 a}$ were determined by ${ }^{1} \mathrm{H}$ NMR of the crude mixture with 1,3,5-trimethoxybenzene as an internal standard.

\section{General procedures for oxidative deprotection of PMB groups by 1/PIFA (Scheme 2)}

\section{Method I}

To a mixture of PMB ether 2 (1 equiv.), 1 (10 mol\%), and $\mathrm{NaHCO}_{3}$ (4 equiv.) in DCM (0.05 M) was added PIFA (1.05 equiv.). The resulting mixture was stirred at room temperature for $2 \mathrm{~h}$. The reaction was quenched with saturated aq. $\mathrm{Na}_{2} \mathrm{~S}_{2} \mathrm{O}_{3}$ and extracted with AcOEt. The organic layer was dried over $\mathrm{Na}_{2} \mathrm{SO}_{4}$, filtered and concentrated in vacuo to give a residue. The residue was purified by MPLC to give the alcohol $\mathbf{3}$.

\section{Method II}

To a mixture of $\mathrm{PMB}$ ether 2 (1 equiv.), 1 (10 mol\%), $\mathrm{NaHCO}_{3}$ (4 equiv.), and $\mathrm{H}_{2} \mathrm{O}$ (2 equiv.) in DCM (0.05 M) was added PIFA (1.05 equiv.). The resulting mixture was stirred at room temperature for $2 \mathrm{~h}$. The reaction was quenched with saturated aq. $\mathrm{Na}_{2} \mathrm{~S}_{2} \mathrm{O}_{3}$ and extracted with AcOEt. The organic layer was dried over $\mathrm{Na}_{2} \mathrm{SO}_{4}$, filtered and concentrated in vacuo to give a residue. The residue was purified by MPLC to give the alcohol 3. 
3-Phenylpropan-1-ol (3a, using 1g of substrate 2a)<smiles>OCCCc1ccccc1</smiles>

3a

To a mixture of $\mathbf{2 a}(1.00 \mathrm{~g}, 3.90 \mathrm{mmol}), \mathbf{1}(89.8 \mathrm{mg}, 0.390 \mathrm{mmol})$, and $\mathrm{NaHCO}_{3}(1.31 \mathrm{~g}, 15.6 \mathrm{mmol})$ in DCM (78 $\mathrm{mL}$ ) was added PIFA (1.76 g, $4.10 \mathrm{mmol})$. The resulting mixture was stirred at room temperature for $2 \mathrm{~h}$. The reaction was quenched with saturated aq. $\mathrm{Na}_{2} \mathrm{~S}_{2} \mathrm{O}_{3}$ and extracted with AcOEt. The organic layer was dried over $\mathrm{Na}_{2} \mathrm{SO}_{4}$, filtered and concentrated in vacuo to give a residue. The residue was purified by MPLC ( $n$-hexane/AcOEt $=1 / 0$ to $4 / 1)$ to give $\mathbf{3 a}(507 \mathrm{mg}, 95 \%)$ as colorless oil.

NMR spectra of the obtained product were consistent with the reported one. ${ }^{1}$

${ }^{1} \mathrm{H}$ NMR (500 MHz, $\left.\mathrm{CDCl}_{3}\right) \delta 7.31-7.26(\mathrm{~m}, 2 \mathrm{H}), 7.22-7.17(\mathrm{~m}, 3 \mathrm{H}), 3.67$ (t, $\left.J=6.4 \mathrm{~Hz}, 2 \mathrm{H}\right), 2.74-2.68(\mathrm{~m}, 2 \mathrm{H})$, 1.94-1.86 (m, 2H), 1.40 (broad s, 1H). ${ }^{13} \mathrm{C}$ NMR (125 MHz, $\left.\mathrm{CDCl}_{3}\right) \delta 141.8,128.44,128.42,125.9,62.3,34.2$, 32.1.

\section{1-Octanol (3b)}<smiles>CC1CCCO1</smiles>

3b

The titled compound was synthesized according to the general procedure (Method I) using $\mathbf{2 b}(250 \mathrm{mg}, 1.00 \mathrm{mmol})$ as a substrate. The obtained crude material was purified by MPLC ( $n$-hexane/AcOEt $=1 / 0$ to $7 / 3)$ to give $\mathbf{3 b}(117$ $\mathrm{mg}, 90 \%$ ) as colorless oil.

NMR spectra of the obtained product were consistent with the reported one. ${ }^{8}$

${ }^{1} \mathrm{H}$ NMR (500 MHz, $\left.\mathrm{CDCl}_{3}\right) \delta 3.63(\mathrm{t}, J=6.7 \mathrm{~Hz}, 2 \mathrm{H}$ ), 1.78 (broad s, $1 \mathrm{H}$ ), 1.56 (quintet, $J=6.9 \mathrm{~Hz}, 2 \mathrm{H}$ ), $1.39-$ $1.22(\mathrm{~m}, 10 \mathrm{H}), 0.88(\mathrm{t}, J=6.9 \mathrm{~Hz}, 3 \mathrm{H}) .{ }^{13} \mathrm{C} \mathrm{NMR}\left(125 \mathrm{MHz}, \mathrm{CDCl}_{3}\right) \delta 63.0,32.8,31.9,29.4,29.3,25.8,22.7,14.1$.

4-Phenyl-2-butanol (3c)<smiles>CC(O)CCc1ccccc1</smiles>

3c

The titled compound was synthesized according to the general procedure (Method I) using $2 \mathbf{c}(270 \mathrm{mg}, 1.00 \mathrm{mmol}$ ) as a substrate. The obtained crude material was purified by MPLC ( $n$-hexane/AcOEt $=1 / 0$ to $4 / 1)$ to give $3 \mathbf{c}(144$ mg, 96\%) as colorless oil.

NMR spectra of the obtained product were consistent with the reported one. ${ }^{9}$

${ }^{1} \mathrm{H}$ NMR (500 MHz, $\left.\mathrm{CDCl}_{3}\right) \delta$ 7.30-7.26 (m, 2H), 7.22-7.16 (m, 3H), 3.87-3.79 (m, 1H), 2.76 (ddd, $J=13.9,9.4$, $6.2 \mathrm{~Hz}, 1 \mathrm{H}), 2.67$ (ddd, $J=13.7,9.2,7.0 \mathrm{~Hz}, 1 \mathrm{H}), 1.84-1.70(\mathrm{~m}, 2 \mathrm{H}), 1.42(\operatorname{broad~s}, 1 \mathrm{H}), 1.23(\mathrm{~d}, J=6.2 \mathrm{~Hz}, 3 \mathrm{H})$. ${ }^{13} \mathrm{C}$ NMR (125 MHz, $\left.\mathrm{CDCl}_{3}\right) \delta 142.1,128.4,125.9,67.6,40.9,32.2,23.7$. 
2-Methyl-4-phenylbutan-2-ol (3d)<smiles>CC(C)(O)CCc1ccccc1</smiles>

The titled compound was synthesized according to the general procedure (Method II) using $2 \mathbf{d}$ (284 mg, 1.00 $\mathrm{mmol}$ ) as a substrate. The obtained crude material was purified by MPLC ( $n$-hexane/AcOEt $=1 / 0$ to $6 / 4$ ) to give $\mathbf{3 d}$ (164 mg, >99\%) as colorless oil.

NMR spectra of the obtained product were consistent with the reported one. ${ }^{2}$

${ }^{1} \mathrm{H}$ NMR (500 MHz, $\mathrm{CDCl}_{3}$ ) $\delta$ 7.31-7.26 (m, 2H), 7.22-7.16 (m, 3H), 2.73-2.68 (m, 2H), 1.83-1.77 (m, 2H), 1.59 (broad s, 1H), $1.29(\mathrm{~s}, 6 \mathrm{H}) .{ }^{13} \mathrm{C} \mathrm{NMR}\left(75 \mathrm{MHz}, \mathrm{CDCl}_{3}\right) \delta 142.6,128.4,128.3,125.8,70.9,45.8,30.8,29.4$.

l-Menthol (3e)

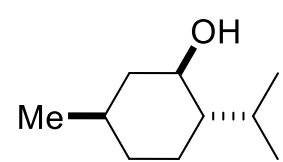

3e

The titled compound was synthesized according to the general procedure (Method I) using $2 \mathbf{e}(276 \mathrm{mg}, 1.00 \mathrm{mmol}$ ) as a substrate. The obtained crude material was purified by MPLC ( $n$-hexane/AcOEt $=1 / 0$ to $4 / 1)$ to give $3 \mathbf{e}(137$ $\mathrm{mg}, 88 \%$ ) as a colorless solid.

NMR spectra of the obtained product were consistent with the reported one. ${ }^{2}$

${ }^{1} \mathrm{H}$ NMR (500 MHz, $\mathrm{CDCl}_{3}$ ) $\delta 3.45-3.38(\mathrm{~m}, 1 \mathrm{H}), 2.21-2.12(\mathrm{~m}, 1 \mathrm{H}), 2.00-1.94(\mathrm{~m}, 1 \mathrm{H}), 1.70-1.57(\mathrm{~m}, 2 \mathrm{H}), 1.48$ 1.37 (m, 1H), 1.29 (broad s, 1H), 1.11 (ddt, $J=12.9,10.1,3.1 \mathrm{~Hz}, 1 \mathrm{H}), 1.02-0.90$ (m, 8H), 0.86 (td, $J=12.3,3.3$ $\mathrm{Hz}, 1 \mathrm{H}), 0.81(\mathrm{~d}, J=7.0 \mathrm{~Hz}, 3 \mathrm{H}) .{ }^{13} \mathrm{C} \mathrm{NMR}\left(125 \mathrm{MHz}, \mathrm{CDCl}_{3}\right) \delta 71.6,50.2,45.1,34.6,31.7,25.9,23.2,22.2$, $21.0,16.1$.

trans-2-Phenylcyclohexan-1-ol (3f)<smiles>OC1CCCCC1c1ccccc1</smiles>

$3 \mathbf{f}$

The titled compound was synthesized according to the general procedure (Method I) using $2 \mathbf{f}$ (296 $\mathrm{mg}, 1.00 \mathrm{mmol}$ ) as a substrate. The obtained crude material was purified by MPLC ( $n$-hexane/AcOEt $=1 / 0$ to $9 / 1)$ to give $\mathbf{3 f}$ ( 169 $\mathrm{mg}, 96 \%)$ as a colorless solid.

NMR spectra of the obtained product were consistent with the reported one. ${ }^{10}$

${ }^{1} \mathrm{H}$ NMR (500 MHz, $\left.\mathrm{CDCl}_{3}\right) \delta$ 7.33-7.28 (m, 2H), 7.25-7.19 (m, 3H), $3.62(\mathrm{td}, J=10.0,4.3 \mathrm{~Hz}, 1 \mathrm{H}), 2.40$ (ddd, $J$ $=12.3,9.9,3.6 \mathrm{~Hz}, 1 \mathrm{H}), 2.12-2.06(\mathrm{~m}, 1 \mathrm{H}), 1.84(\mathrm{dtd}, J=14.3,4.5,4.0,2.0 \mathrm{~Hz}, 2 \mathrm{H}), 1.78-1.71(\mathrm{~m}, 1 \mathrm{H}), 1.65$ (broad s, 1H), 1.55-1.44 (m, 1H), 1.44-1.25 (m, 3H). $\left.{ }^{13} \mathrm{C} \mathrm{NMR} \mathrm{(125} \mathrm{MHz,} \mathrm{CDCl}_{3}\right) \delta 143.4,128.8,128.0,126.8$, $74.4,53.2,34.5,33.4,26.1,25.1$. 
$(8 R, 9 S, 13 S, 14 S, 17 S)$-17-Hydroxy-13-methyl-7,8,9,11,12,13,14,15,16,17-decahydro-6H-cyclopenta[ $a]$ phenanthren3-yl benzoate (3g)

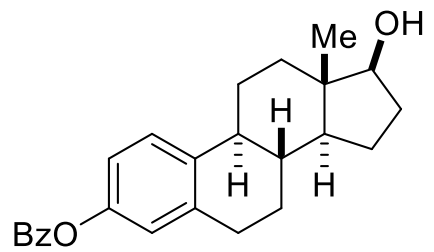

$3 \mathrm{~g}$

The titled compound was synthesized according to the general procedure (Method I) for oxidative deprotection of PMB groups using $\mathbf{2 g}$ ( $49.7 \mathrm{mg}, 1.00 \mathrm{mmol})$ as a substrate. The obtained crude material was purified by MPLC ( $n$ hexane/AcOEt $=1 / 0$ to $4 / 1)$ to give $\mathbf{3 g}(34.3 \mathrm{mg}, 91 \%)$ as a colorless amorphous solid.

NMR spectra of the obtained product were consistent with the reported one. ${ }^{11}$

${ }^{1} \mathrm{H}$ NMR $\left(300 \mathrm{MHz}, \mathrm{CDCl}_{3}\right) \delta 8.23-8.17(\mathrm{~m}, 2 \mathrm{H}), 7.67-7.60(\mathrm{~m}, 1 \mathrm{H}), 7.54-7.47(\mathrm{~m}, 2 \mathrm{H}), 7.34(\mathrm{~d}, J=8.3 \mathrm{~Hz}, 1 \mathrm{H})$, $6.97(\mathrm{dd}, J=8.4,2.6 \mathrm{~Hz}, 1 \mathrm{H}), 6.93(\mathrm{~d}, J=2.5 \mathrm{~Hz}, 1 \mathrm{H}), 3.75(\mathrm{ddd}, J=9.0,7.8,6.1 \mathrm{~Hz}, 1 \mathrm{H}), 3.00-2.79$ (m, 2H), 2.42-2.07 (m, 3H), 2.01-1.86 (m, 2H), 1.77-1.65 (m, 1H), 1.63-1.15 (m, 8H), $0.80(\mathrm{~s}, 3 \mathrm{H}) .{ }^{13} \mathrm{C}$ NMR (75 MHz, $\left.\mathrm{CDCl}_{3}\right) \delta 165.5,148.7,138.4,138.1,133.5,130.2,129.7,128.6,126.5,121.7,118.7,81.9,50.1,44.2,43.3,38.5$, $36.7,30.6,29.6,27.1,26.2,23.2,11.1$.

Benzyl alcohol (3h)<smiles>OCc1ccccc1</smiles>

The titled compound was synthesized according to the general procedure (Method II) using $\mathbf{2 h}$ (228 mg, 1.00 $\mathrm{mmol}$ ) as a substrate. The obtained crude material was purified by MPLC ( $n$-hexane/AcOEt $=1 / 0$ to $2 / 1)$ to give $\mathbf{3 h}$ (76.1 mg, 70\%) as colorless oil.

NMR spectra of the obtained product were consistent with the reported one. ${ }^{12}$

${ }^{1} \mathrm{H}$ NMR $\left(500 \mathrm{MHz}, \mathrm{CDCl}_{3}\right) \delta$ 7.37-7.33 (m, 4H), 7.32-7.26 (m, 1H), 4.67 (s, 2H), 1.94 (broad s, $\left.1 \mathrm{H}\right) .{ }^{13} \mathrm{C}$ NMR $\left(125 \mathrm{MHz}, \mathrm{CDCl}_{3}\right) \delta 140.9,128.6,127.7,127.0,65.3$.

1-Phenylethanol (3i)<smiles>CC(O)c1ccccc1</smiles>

The titled compound was synthesized according to the general procedure (Method II) using $2 \mathbf{i}$ (242 $\mathrm{mg}, 1.00 \mathrm{mmol}$ ) as a substrate. The obtained crude material was purified by MPLC ( $n$-hexane/AcOEt $=1 / 0$ to $6 / 4)$ to give $3 \mathbf{i}(92.5$ $\mathrm{mg}, 76 \%$ ) as colorless oil.

NMR spectra of the obtained product were consistent with the reported one. ${ }^{13}$ 
${ }^{1} \mathrm{H}$ NMR (500 MHz, $\left.\mathrm{CDCl}_{3}\right) \delta 7.41-7.32(\mathrm{~m}, 4 \mathrm{H}), 7.30-7.25(\mathrm{~m}, 1 \mathrm{H}), 4.89$ (q, $\left.J=6.4 \mathrm{~Hz}, 1 \mathrm{H}\right), 1.92$ (broad s, 1H), $1.49(\mathrm{~d}, J=6.4 \mathrm{~Hz}, 3 \mathrm{H}) .{ }^{13} \mathrm{C} \mathrm{NMR}\left(125 \mathrm{MHz}, \mathrm{CDCl}_{3}\right) \delta 145.8,128.5,127.5,125.4,70.4,25.2$.

2,2-Dimethyl-1-phenylpropan-1-ol (3j)<smiles>CC(C)(C)C(O)c1ccccc1</smiles>

The titled compound was synthesized according to the general procedure (Method II) using $\mathbf{2 j}$ ( $284 \mathrm{mg}, 1.00 \mathrm{mmol}$ ) as a substrate. The obtained crude material was purified by MPLC ( $n$-hexane/AcOEt $=1 / 0$ to $9 / 1)$ to give $\mathbf{3 j}$ (149 mg, 91\%) as colorless oil.

NMR spectra of the obtained product were consistent with the reported one. ${ }^{3}$

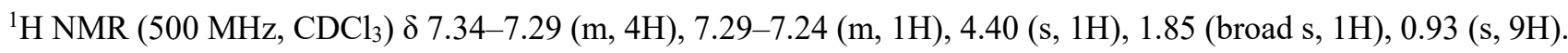
${ }^{13} \mathrm{C}$ NMR $\left(125 \mathrm{MHz}, \mathrm{CDCl}_{3}\right) \delta 142.2,127.62,127.58,127.3,82.4,35.6,25.9$.

1-Octen-3-ol (3k)<smiles>C=CC(O)C(=O)O</smiles>

The titled compound was synthesized according to the general procedure (Method II) using $2 \mathbf{k}$ ( $248 \mathrm{mg}, 1.00$ $\mathrm{mmol})$ as a substrate. The obtained crude material was purified by MPLC ( $n$-hexane/AcOEt $=1 / 0$ to $4 / 1)$ to give $\mathbf{3 k}$ (71 $\mathrm{mg}, 55 \%)$ as colorless oil.

NMR spectra of the obtained product were consistent with the reported one. ${ }^{14}$

${ }^{1} \mathrm{H}$ NMR (300 MHz, $\left.\mathrm{CDCl}_{3}\right)$ 8 5.99-5.79 (m, 1H), 5.30-5.19 (m, 1H), 5.16-5.08 (m, 1H), 4.17-4.07 (m, 1H), 1.69$1.46(\mathrm{~m}, 3 \mathrm{H}), 1.46-1.26(\mathrm{~m}, 6 \mathrm{H}), 0.91(\mathrm{t}, J=7.1 \mathrm{~Hz}, 3 \mathrm{H}) .{ }^{13} \mathrm{C} \mathrm{NMR}\left(75 \mathrm{MHz}, \mathrm{CDCl}_{3}\right) \delta 141.4,114.6,73.3,37.0$, $31.8,25.0,22.6,14.1$.

Oct-2-yn-1-ol (31)<smiles>CC#CCO</smiles>

The titled compound was synthesized according to the general procedure (Method II) using $2 \mathbf{2}$ (246 mg, $1.00 \mathrm{mmol}$ ) as a substrate. The obtained crude material was purified by MPLC ( $n$-hexane/AcOEt $=1 / 0$ to $2 / 1)$ to give 31 ( 65 $\mathrm{mg}, 52 \%$ ) as colorless oil.

NMR spectra of the obtained product were consistent with the reported one. ${ }^{15}$

${ }^{1} \mathrm{H}$ NMR $\left(500 \mathrm{MHz}, \mathrm{CDCl}_{3}\right) \delta 4.25(\mathrm{dt}, J=5.8,2.2 \mathrm{~Hz}, 2 \mathrm{H}), 2.21(\mathrm{tt}, J=7.2,2.2 \mathrm{~Hz}, 2 \mathrm{H}), 1.70-1.62(\mathrm{~m}, 1 \mathrm{H})$, 1.55-1.47 (m, 2H), 1.41-1.27 (m, 4H), 0.90 (t, $J=7.1 \mathrm{~Hz}, 3 \mathrm{H}) .{ }^{13} \mathrm{C}$ NMR $\left(125 \mathrm{MHz}, \mathrm{CDCl}_{3}\right) \delta 86.7,78.3,51.4$, $31.1,28.3,22.2,18.7,14.0$. 
6-Methoxyhexan-1ol (3m)

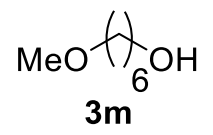

The titled compound was synthesized according to the general procedure (Method I) using $\mathbf{2 m}$ ( $252 \mathrm{mg}, 1.00$ mmol) as a substrate. The obtained crude material was purified by MPLC ( $n$-hexane/AcOEt $=1 / 0$ to $2 / 3$ ) to give 3m (107 mg, 81\%) as pale yellow oil.

NMR spectra of the obtained product were consistent with the reported one. ${ }^{16}$

${ }^{1} \mathrm{H}$ NMR (300 MHz, $\left.\mathrm{CDCl}_{3}\right) \delta 3.65(\mathrm{t}, J=6.5 \mathrm{~Hz}, 2 \mathrm{H}), 3.38(\mathrm{t}, J=6.5 \mathrm{~Hz}, 2 \mathrm{H}), 3.33(\mathrm{~s}, 3 \mathrm{H}), 1.62-1.52(\mathrm{~m}, 4 \mathrm{H})$, 1.42-1.35 (m, 4H), 1.32 (broad s, $1 \mathrm{H}) .{ }^{13} \mathrm{C}$ NMR $\left(75 \mathrm{MHz}, \mathrm{CDCl}_{3}\right) \delta 72.8,62.6,58.5,32.7,29.6,26.0,25.7$.

2-(\{6-[(4-Methoxybenzyl)oxy]hexyl\}oxy)pyrimidine (3n)<smiles>CC(O)Oc1ncccn1</smiles>

$3 n$

The titled compound was synthesized according to the general procedure (Method I) using $2 \mathbf{n}(31.6 \mathrm{mg}, 0.100$ $\mathrm{mmol})$ as a substrate. The obtained crude material was purified by preparative TLC $(n$-hexane/AcOEt $=1 / 2)$ to give 3n (10.0 mg, 51\%) as colorless oil.

${ }^{1} \mathrm{H}$ NMR $\left(500 \mathrm{MHz}, \mathrm{CDCl}_{3}\right) \delta 8.51(\mathrm{~d}, J=4.8 \mathrm{~Hz}, 2 \mathrm{H}), 6.93(\mathrm{t}, J=4.7 \mathrm{~Hz}, 1 \mathrm{H}), 4.36(\mathrm{t}, J=6.6 \mathrm{~Hz}, 2 \mathrm{H}), 3.66(\mathrm{t}, J$ $=6.6 \mathrm{~Hz}, 2 \mathrm{H}), 1.89-1.80(\mathrm{~m}, 3 \mathrm{H}), 1.64-1.57(\mathrm{~m}, 2 \mathrm{H}), 1.56-1.49(\mathrm{~m}, 2 \mathrm{H}), 1.48-1.40(\mathrm{~m}, 2 \mathrm{H}) .{ }^{13} \mathrm{C}$ NMR $(125 \mathrm{MHz}$, $\left.\mathrm{CDCl}_{3}\right) \delta 165.3,159.2,114.8,67.6,62.8,32.7,28.8,25.8,25.5$. IR (neat) 3364, 2932, 1562, $1424 \mathrm{~cm}^{-1}$. HRMS (EI) $m / z:[\mathrm{M}]^{+}$Calcd for $\mathrm{C}_{10} \mathrm{H}_{16} \mathrm{~N}_{2} \mathrm{O}_{2}$ 196.1212; Found 196.1212.

\section{1,10-Decanediol (3o)}<smiles>C[13CH]1O[13CH]2O[13CH]1O2</smiles>

The titled compound was synthesized according to the general procedure (Method I) using 20 (294 mg, $1.00 \mathrm{mmol}$ ) as a substrate. The obtained crude material was purified by MPLC ( $n$-hexane/AcOEt $=1 / 0$ to $3 / 7)$ to give $3 \mathbf{o}(146$ $\mathrm{mg}, 84 \%$ ) as colorless oil.

NMR spectra of the obtained product were consistent with the reported one. ${ }^{17}$ ${ }^{1} \mathrm{H}$ NMR $\left(500 \mathrm{MHz}, \mathrm{CDCl}_{3}\right) \delta 3.57(\mathrm{t}, J=6.6 \mathrm{~Hz}, 4 \mathrm{H}), 1.50$ (quintet, $\left.J=6.7 \mathrm{~Hz}, 4 \mathrm{H}\right), 1.33-1.17(\mathrm{~m}, 14 \mathrm{H}) .{ }^{13} \mathrm{C}$ NMR (125 MHz, $\left.\mathrm{CDCl}_{3}\right) \delta 63.1,32.8,29.5,29.4,25.7$. 
(2R,3S)-2-[3,4-Bis(tosyloxy)phenyl]-3-hydroxychromane-5,7-diyl bis(4-methylbenzenesulfonate) (3p)

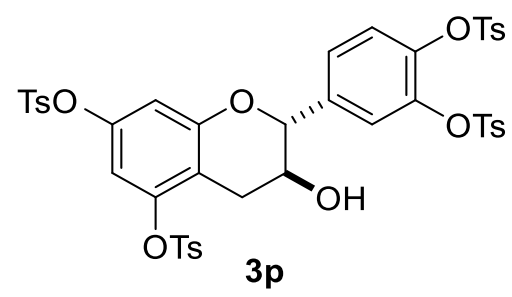

To a mixture of $\mathbf{2 p}(24.0 \mathrm{mg}, 23.4 \mu \mathrm{mol}), \mathbf{1}(0.54 \mathrm{mg}, 2.3 \mu \mathrm{mol})$, and $\mathrm{NaHCO}_{3}(7.9 \mathrm{mg}, 93.5 \mu \mathrm{mol})$ in DCM (1.0 $\mathrm{mL})$ was added PIFA $(13.1 \mathrm{mg}, 30.4 \mu \mathrm{mol})$. The resulting mixture was stirred at room temperature for $3 \mathrm{~h}$. The reaction was quenched with saturated aq. $\mathrm{Na}_{2} \mathrm{~S}_{2} \mathrm{O}_{3}$ and extracted with $\mathrm{CHCl}_{3}$. The organic layer was dried over $\mathrm{Na}_{2} \mathrm{SO}_{4}$, filtered and concentrated in vacuo to give a residue. The residue was purified by MPLC ( $n$-hexane/AcOEt $=9 / 1$ to $3 / 7)$ gave $3 \mathbf{p}(18.8 \mathrm{mg}, 89 \%)$ as a colorless amorphous solid.

${ }^{1} \mathrm{H}$ NMR (500 MHz, $\left.\mathrm{CDCl}_{3}\right)$ 反 7.75-7.70 (m, 4H), 7.68-7.62 (m, 4H), 7.38-7.35 (m, 4H), 7.31-7.27 (m, 5H), 7.25$7.20(\mathrm{~m}, 2 \mathrm{H}), 6.52(\mathrm{~d}, J=2.3 \mathrm{~Hz}, 1 \mathrm{H}), 6.33(\mathrm{~d}, J=2.3 \mathrm{~Hz}, 1 \mathrm{H}), 4.70(\mathrm{~d}, J=7.7 \mathrm{~Hz}, 1 \mathrm{H}), 3.87(\mathrm{td}, J=10.2,8.3,5.9$ Hz, 1H), 2.90 (dd, $J=16.9,5.3 \mathrm{~Hz}, 1 \mathrm{H}), 2.59$ (dd, $J=16.8,8.6 \mathrm{~Hz}, 1 \mathrm{H}), 2.49$ (s, 3H), 2.47 (s, 3H), 2.47 (s, 3H), 2.46 (s, 3H), 1.85 (broad d, $J=4.1 \mathrm{~Hz}, 1 \mathrm{H}) .{ }^{13} \mathrm{C} \mathrm{NMR}\left(125 \mathrm{MHz}, \mathrm{CDCl}_{3}\right) \delta$ 154.7, 148.3, 148.2, 146.1, 146.0, $145.9,141.4,141.3,137.8,132.4,132.2,132.1,132.0,130.14,130.05,129.9,128.6,128.53,128.47,128.4,126.2$, $124.5,122.8,114.2,109.7,109.5,80.4,66.8,27.9,21.81,21.79$. IR (neat) $3542,1594,1371,1173,1081,809,543$ $\mathrm{cm}^{-1}$. HRMS (EI) $m / z$ : [M+Na] $]^{+}$Calcd for $\mathrm{C}_{43} \mathrm{H}_{38} \mathrm{NaO}_{14} \mathrm{~S}_{4}$ 929.1037; Found 929.1027.

Deprotection of $\mathbf{2 p}$ by using DDQ

To a solution of $\mathbf{2 p}(24.0 \mathrm{mg}, 23.4 \mu \mathrm{mol})$ in DCM $(1.0 \mathrm{~mL})$ and $\mathrm{H}_{2} \mathrm{O}(20 \mu \mathrm{L})$ was added DDQ $(6.9 \mathrm{mg}, 30.4 \mu \mathrm{mol})$. The resulting mixture was stirred at room temperature for $3 \mathrm{~h}$. The reaction was quenched with saturated aq. $\mathrm{Na}_{2} \mathrm{~S}_{2} \mathrm{O}_{3}$ and extracted with $\mathrm{CHCl}_{3}$. The organic layer was dried over $\mathrm{Na}_{2} \mathrm{SO}_{4}$, filtered and concentrated in vacuo to give a residue. The residue was purified by preparative TLC $(n$-hexane/AcOEt $=1 / 1)$ gave $\mathbf{3 p}(6.4 \mathrm{mg}, 30 \%)$ as a colorless amorphous solid.

4-Iodophenylethanol (3q)<smiles>OCc1ccc(I)cc1</smiles>

$3 q$

The titled compound was synthesized according to the general procedure (Method II) using $\mathbf{2 q}$ ( $354 \mathrm{mg}, 1.00$ mmol) as a substrate. The obtained crude material was purified by MPLC ( $n$-hexane/AcOEt $=1 / 0$ to $4 / 1)$ to give $\mathbf{3 q}$ (201 $\mathrm{mg}, 86 \%)$ as a colorless solid.

NMR spectra of the obtained product were consistent with the reported one. ${ }^{18}$

${ }^{1} \mathrm{H}$ NMR (300 MHz, $\left.\mathrm{CDCl}_{3}\right) \delta 7.69(\mathrm{~d}, J=8.3 \mathrm{~Hz}, 2 \mathrm{H}), 7.12(\mathrm{~d}, J=8.5 \mathrm{~Hz}, 2 \mathrm{H}), 4.65(\mathrm{~d}, J=5.8 \mathrm{~Hz}, 2 \mathrm{H}), 1.73(\mathrm{t}, J$ $=5.9 \mathrm{~Hz}, 1 \mathrm{H}) .{ }^{13} \mathrm{C} \mathrm{NMR}\left(125 \mathrm{MHz}, \mathrm{CDCl}_{3}\right) \delta 140.5,137.6,128.8,93.0,64.7$. 
9-Decen-1-ol (3r)<smiles>C=CC(O)=[13C](O)[15Br]</smiles>

The titled compound was synthesized according to the general procedure (Method I) using $2 \mathbf{r}$ (276 mg, $1.00 \mathrm{mmol}$ ) as a substrate. The obtained crude material was purified by MPLC ( $n$-hexane/AcOEt $=1 / 0$ to $4 / 1)$ to give $3 \mathbf{r}(123$ $\mathrm{mg}, 79 \%$ ) as colorless oil.

NMR spectra of the obtained product were consistent with the reported one. ${ }^{19}$

${ }^{1} \mathrm{H}$ NMR $\left(500 \mathrm{MHz}, \mathrm{CDCl}_{3}\right.$ ) $\delta 5.81$ (dddd, $\left.J=15.7,10.1,7.3,6.0 \mathrm{~Hz}, 1 \mathrm{H}\right), 5.03-4.88$ (m, 2H), 3.64 (t, $J=6.5 \mathrm{~Hz}$, $2 \mathrm{H}), 2.08-2.01(\mathrm{~m}, 2 \mathrm{H}), 1.63-1.53(\mathrm{~m}, 2 \mathrm{H}), 1.40-1.23(\mathrm{~m}, 11 \mathrm{H}) .{ }^{13} \mathrm{C} \mathrm{NMR}\left(125 \mathrm{MHz}, \mathrm{CDCl}_{3}\right) \delta 139.2,114.2$, $63.1,33.8,32.8,29.5,29.4,29.1,28.9,25.7$.

6-(Benzyloxy)hexan-1-ol (3t)<smiles></smiles>

3t

The titled compound was synthesized according to the general procedure (Method I) using $2 \mathbf{t}(30.0 \mathrm{mg}, 91.3 \mu \mathrm{mol})$ and PIFA (43.2 mg, $0.100 \mathrm{mmol}, 1.1$ equiv.). The obtained crude material was purified by MPLC ( $n$-hexane/AcOEt $=1 / 0$ to $6 / 4)$ to give $3 \mathbf{t}(16.9 \mathrm{mg}, 89 \%)$ as colorless oil. Debenzylated SI-7 $(0.3 \mathrm{mg}, 1 \%)$ was also obtained as colorless oil.

NMR spectra of the obtained product were consistent with the reported one. ${ }^{20}$

Colorless oil. ${ }^{1} \mathrm{H}$ NMR (300 MHz, $\left.\mathrm{CDCl}_{3}\right) \delta$ 7.39-7.20 (m, 5H), 4.49 (s, 2H), 3.57 (t, $\left.J=6.6 \mathrm{~Hz}, 2 \mathrm{H}\right), 3.46$ (t, $J=$ $6.6 \mathrm{~Hz}, 2 \mathrm{H}), 2.07$ (broad s, $1 \mathrm{H}), 1.68-1.49(\mathrm{~m}, 4 \mathrm{H}), 1.45-1.30(\mathrm{~m}, 4 \mathrm{H}) .{ }^{13} \mathrm{C} \mathrm{NMR}\left(75 \mathrm{MHz}, \mathrm{CDCl}_{3}\right) \delta 138.6,128.4$, $127.7,127.6,72.9,70.4,62.8,32.7,29.7,26.0,25.6$.

6-[(4-Methoxybenzyl)oxy]hexan-1-ol (SI-7)

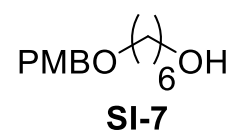

Colorless oil. ${ }^{1} \mathrm{H}$ NMR (500 MHz, $\left.\mathrm{CDCl}_{3}\right) \delta$ 7.28-7.24 (m, 2H), 6.90-6.86 (m, 2H), $4.43(\mathrm{~s}, 2 \mathrm{H}), 3.80(\mathrm{~s}, 3 \mathrm{H}), 3.61$ (t, $J=6.7 \mathrm{~Hz}, 2 \mathrm{H}), 3.44(\mathrm{t}, J=6.6 \mathrm{~Hz}, 2 \mathrm{H}), 1.65-1.52(\mathrm{~m}, 5 \mathrm{H}), 1.43-1.32(\mathrm{~m}, 4 \mathrm{H}) .{ }^{13} \mathrm{C} \mathrm{NMR}\left(75 \mathrm{MHz}, \mathrm{CDCl}_{3}\right) \delta$ $159.1,130.7,129.3,113.8,72.6,70.1,62.9,55.3,32.7,29.7,26.0,25.6$.

NMR spectra of the obtained product were consistent with the reported one. ${ }^{21}$ 
6-[(Naphthalen-2-ylmethoxy)methoxyhexan-1-ol (3u)

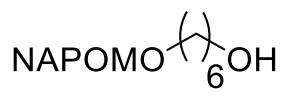

$3 u$

The titled compound was synthesized according to the general procedure (Method I) using $2 \mathbf{t}$ (37.3 $\mathrm{mg}, 91.3 \mu \mathrm{mol})$ and PIFA (43.2 mg, $0.100 \mathrm{mmol}, 1.1$ equiv.). The obtained crude material was purified by MPLC ( $n$-hexane/AcOEt $=9 / 1$ to $2 / 3)$ to give $3 \mathbf{t}(24.7 \mathrm{mg}, 94 \%)$ as colorless oil. The NMR yields of $3 \mathbf{u}(94 \%)$ and SI-7 (0 \%) were determined by ${ }^{1} \mathrm{H}$ NMR analysis of the crude product with 1,3,5-trimethoxybenzene as an internal standard. ${ }^{1} \mathrm{H}$ NMR (500 MHz, $\mathrm{CDCl}_{3}$ ) $\delta$ 7.85-7.80 (m, 4H), 7.50-7.44 (m, 3H), 4.80 (s, 2H), 4.77 (s, 2H), 3.65-3.59 (m, $4 \mathrm{H}$ ), 1.63 (quintet, $J=6.7 \mathrm{~Hz}, 2 \mathrm{H}$ ), 1.56 (quintet, $J=6.7 \mathrm{~Hz}, 2 \mathrm{H}), 1.45-1.35(\mathrm{~m}, 4 \mathrm{H}), 1.31$ (broad s, $1 \mathrm{H}) .{ }^{13} \mathrm{C}$ NMR $\left(125 \mathrm{MHz}, \mathrm{CDCl}_{3}\right) \delta 135.5,133.3,133.0,128.2,127.9,127.7,126.6,126.2,125.94,125.90,94.7,69.4,68.1,63.0$, 32.7, 29.7, 26.1, 25.6. IR (neat) 3407, 2932, 1038, $728 \mathrm{~cm}^{-1}$. HRMS (EI) $\mathrm{m} / z$ : [M] ${ }^{+}$Calcd for $\mathrm{C}_{18} \mathrm{H}_{24} \mathrm{O}_{3} 288.1726$; Found 288.1725 .

6-(Acetoxy)hexan-1-ol (3v)

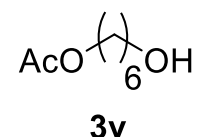

The titled compound was synthesized according to the general procedure (Method I) using $2 \mathbf{v}$ (280 $\mathrm{mg}, 1.00 \mathrm{mmol}$ ) as a substrate. The obtained crude material was purified by preparative TLC $(n$-hexane/AcOEt $=3 / 1)$ to give $\mathbf{3 v}$ (145 mg, 91\%) as colorless oil.

NMR spectra of the obtained product were consistent with the reported one. ${ }^{22}$

${ }^{1} \mathrm{H}$ NMR (300 MHz, CDCl 3$) \delta 4.06(\mathrm{t}, J=6.7 \mathrm{~Hz}, 2 \mathrm{H}), 3.63(\mathrm{t}, J=6.5 \mathrm{~Hz}, 2 \mathrm{H}), 2.05(\mathrm{~s}, 3 \mathrm{H}), 2.01$ (broad s, $1 \mathrm{H}$ ), 1.71-1.52 (m, 4H), 1.46-1.33 (m, 4H). ${ }^{13} \mathrm{C}$ NMR $\left(75 \mathrm{MHz}, \mathrm{CDCl}_{3}\right) \delta$ 171.4, 64.5, 62.7, 32.6, 28.6, 25.7, 25.4, 21.0.

6-(Methoxymethyl)hexan-1-ol (3w)

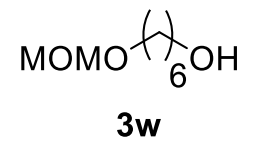

The titled compound was synthesized according to the general procedure (Method I) using $\mathbf{2 w}$ ( $282 \mathrm{mg}, 1.00$ $\mathrm{mmol})$ as a substrate. The obtained crude material was purified by MPLC $(n$-hexane/AcOEt $=1 / 0$ to $7 / 3)$ to give 3w (150 mg, 93\%) as colorless oil.

NMR spectra of the obtained product were consistent with the reported one. ${ }^{23}$

${ }^{1} \mathrm{H}$ NMR (300 MHz, $\left.\mathrm{CDCl}_{3}\right) \delta 4.62(\mathrm{~s}, 2 \mathrm{H}), 3.69-3.61(\mathrm{~m}, 2 \mathrm{H}), 3.53$ (t, $\left.J=6.6 \mathrm{~Hz}, 2 \mathrm{H}\right), 3.36(\mathrm{~s}, 3 \mathrm{H}), 1.65-1.55$ (m, 4H), 1.45-1.36 (m, 4H), 1.27 (broad s, $1 \mathrm{H}) .{ }^{13} \mathrm{C} \mathrm{NMR}\left(75 \mathrm{MHz}, \mathrm{CDCl}_{3}\right) \delta$ 96.4, 67.7, 62.8, 55.1, 32.7, 29.7, 26.0, 25.6 . 


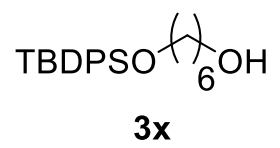

The titled compound was synthesized according to the general procedure (Method I) using $\mathbf{2} \mathbf{x}(47.7 \mathrm{mg}, 0.100$ $\mathrm{mmol})$ as a substrate. The obtained crude material was purified by preparative TLC ( $n$-hexane/AcOEt $=3 / 1)$ to give 3x (32.9 mg, 92\%) as colorless oil.

NMR spectra of the obtained product were consistent with the reported one. ${ }^{23}$

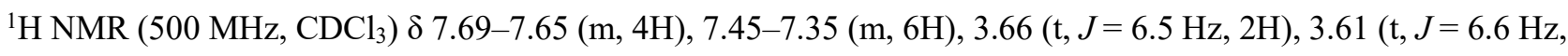
2H), $1.60-1.51(\mathrm{~m}, 4 \mathrm{H}), 1.43-1.29(\mathrm{~m}, 5 \mathrm{H}), 1.05(\mathrm{~s}, 9 \mathrm{H}) .{ }^{13} \mathrm{C} \mathrm{NMR}\left(125 \mathrm{MHz}, \mathrm{CDCl}_{3}\right) \delta 135.6,134.2,129.5$, $127.6,63.9,63.0,32.8,32.5,26.9,25.6,25.5,19.3$.

Benzyl 4-hydroxypiperidine-1-carboxylate (3y)<smiles>CC(C)(C)OC(=O)N1CCC(O)CC1</smiles>

The titled compound was synthesized according to the general procedure (Method I) using $\mathbf{2 y}$ (35.5 mg, 0.100 $\mathrm{mmol})$ as a substrate. The obtained crude material was purified by preparative TLC ( $n$-hexane/AcOEt $=2 / 1)$ to give 3y $(17.1 \mathrm{mg}, 73 \%)$ as colorless oil.

NMR spectra of the obtained product were consistent with the reported one. ${ }^{23}$

${ }^{1} \mathrm{H}$ NMR (500 MHz, $\left.\mathrm{CDCl}_{3}\right) \delta 7.40-7.28(\mathrm{~m}, 5 \mathrm{H}), 5.12(\mathrm{~s}, 2 \mathrm{H}), 3.95-3.87(\mathrm{~m}, 2 \mathrm{H}), 3.84(\mathrm{tt}, J=8.3,3.8 \mathrm{~Hz}, 1 \mathrm{H})$, 3.13 (ddd, $J=13.3,9.5,3.4 \mathrm{~Hz}, 2 \mathrm{H}), 2.24$ (broad s, $1 \mathrm{H}), 1.90-1.79(\mathrm{~m}, 2 \mathrm{H}), 1.53-1.42(\mathrm{~m}, 2 \mathrm{H}) .{ }^{13} \mathrm{C}$ NMR $(125$ $\left.\mathrm{MHz}, \mathrm{CDCl}_{3}\right) \delta 155.4,136.8,128.5,128.0,127.9,67.3,67.2,41.4$.

\section{Deprotection of phenol derivative $2 \mathrm{~s}$}

To a mixture of $2 \mathrm{~s}(21.4 \mathrm{mg}, 0.100 \mathrm{mmol}), \mathbf{1}(2.3 \mathrm{mg}, 10 \mu \mathrm{mol})$, and $\mathrm{NaHCO}_{3}(33.6 \mathrm{mg}, 0.400 \mathrm{mmol})$ in DCM (2.0 $\mathrm{mL}$ ) was added PIFA $(45.2 \mathrm{mg}, 0.105 \mathrm{mmol})$. The resulting mixture was stirred at room temperature for $2 \mathrm{~h}$. The reaction was quenched with saturated aq. $\mathrm{Na}_{2} \mathrm{~S}_{2} \mathrm{O}_{3}$ and extracted with $\mathrm{CHCl}_{3}$. The organic layer was dried over $\mathrm{Na}_{2} \mathrm{SO}_{4}$, filtered and concentrated in vacuo to give a residue. The yield of $3 \mathbf{s}(<5 \%)$ and $2 \mathbf{s}(26 \%)$ were determined by ${ }^{1} \mathrm{H}$ NMR of the residue with 1,3,5-trimethoxybenzene as an internal standard.

The structure of $\mathbf{3 s}$ was identified by the comparison of ${ }^{1} \mathrm{H}$ NMR with the purchased $\mathbf{3 s}$. 


\section{Deprotection of PMB-protected benzyl alcohol (2h) without addition of water}

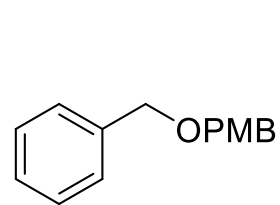

$2 \mathrm{~h}$

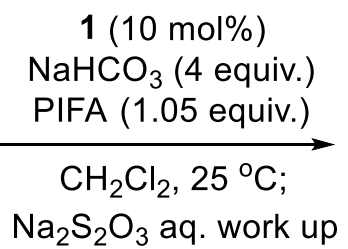<smiles>OCc1ccccc1</smiles>

$3 \mathrm{~h}$

$36 \%$<smiles>O=C(OCc1ccccc1)C(F)(F)F</smiles>

SI-8

$35 \%$

To a mixture of $\mathbf{2 h}(22.8 \mathrm{mg}, 0.100 \mathrm{mmol}), \mathbf{1}(2.3 \mathrm{mg}, 10 \mu \mathrm{mol})$, and $\mathrm{NaHCO}_{3}(33.6 \mathrm{mg}, 0.400 \mathrm{mmol})$ in DCM (2.0 $\mathrm{mL}$ ) was added PIFA ( $45.2 \mathrm{mg}, 0.105 \mathrm{mmol}$ ). The resulting mixture was stirred at room temperature for $3 \mathrm{~h}$. The reaction was quenched with saturated aq. $\mathrm{Na}_{2} \mathrm{~S}_{2} \mathrm{O}_{3}$ and extracted with $\mathrm{CHCl}_{3}$. The organic layer was dried over $\mathrm{Na}_{2} \mathrm{SO}_{4}$, filtered and concentrated in vacuo to give a residue. The yield of $\mathbf{3 h}$ (34\%) and SI-8 (35\%) were determined by ${ }^{1} \mathrm{H}$ NMR of the residue with 1,3,5-trimethoxybenzene as an internal standard. ${ }^{1} \mathrm{H}$ NMR spectra of the SI-8 was consistent with the reported one. ${ }^{24}$

\section{General procedure for direct synthesis of ketones and aldehydes from PMB-protected alcohols by 1/PIFA} (Scheme 3)

\section{Method III}

To a mixture of $\mathrm{PMB}$ ether 2 (1.00 equiv.), 1 (10 mol\%), $\mathrm{NaHCO}_{3}$ (4 equiv.), and $\mathrm{H}_{2} \mathrm{O}$ (2 equiv.) in DCM ( $\left.0.05 \mathrm{M}\right)$ was added PIFA (2.2 equiv.). The resulting mixture was stirred at room temperature for $3 \mathrm{~h}$. The reaction was quenched with saturated aq. $\mathrm{Na}_{2} \mathrm{~S}_{2} \mathrm{O}_{3}$ and extracted with AcOEt. The organic layer was dried over $\mathrm{Na}_{2} \mathrm{SO}_{4}$, filtered and concentrated in vacuo to give a residue. The residue was purified by MPLC to give carbonyl compounds 4 .

Specific procedures and characterization data are written below.

3-Phenylpropanal (4a)<smiles>O=CCCc1ccccc1</smiles>

4a

The titled compound was synthesized according to the general procedure (Method III) using 2a (256 mg, 1.00 mmol) as a substrate. The obtained crude material was purified by MPLC ( $n$-hexane/AcOEt $=1 / 0$ to 19/1) to give 4a (81 mg, 60\%) as colorless oil.

NMR spectra of the obtained product were consistent with the reported one. ${ }^{25}$ ${ }^{1} \mathrm{H}$ NMR (500 MHz, $\left.\mathrm{CDCl}_{3}\right) \delta 9.81$ (t, $\left.J=1.4 \mathrm{~Hz}, 1 \mathrm{H}\right), 7.33-7.27$ (m, 2H), 7.24-7.17 (m, 3H), 2.96 (t, J= 7.6 Hz, $2 \mathrm{H}), 2.78(\mathrm{td}, J=7.6,1.5 \mathrm{~Hz}, 2 \mathrm{H}) .{ }^{13} \mathrm{C}$ NMR $\left(125 \mathrm{MHz}, \mathrm{CDCl}_{3}\right) \delta 201.6,140.4,128.6,128.3,126.3,45.3,28.1$. 
<smiles>CC(=O)CCc1ccccc1</smiles>

The titled compound was synthesized according to the general procedure (Method III) using $2 \mathbf{c}$ ( $256 \mathrm{mg}, 1.00$ mmol) as a substrate. The obtained crude material was purified by MPLC ( $n$-hexane/AcOEt $=1 / 0$ to $19 / 1)$ to give $4 \mathbf{c}(124 \mathrm{mg}, 84 \%)$ as colorless oil.

NMR spectra of the obtained product were consistent with the reported one. ${ }^{26}$

${ }^{1} \mathrm{H}$ NMR (500 MHz, $\left.\mathrm{CDCl}_{3}\right) \delta 7.30-7.26(\mathrm{~m}, 2 \mathrm{H}), 7.21-7.16(\mathrm{~m}, 3 \mathrm{H}), 2.89(\mathrm{t}, J=7.6 \mathrm{~Hz}, 2 \mathrm{H}), 2.76$ (t, $J=7.6 \mathrm{~Hz}$, 2H), $2.14(\mathrm{~s}, 3 \mathrm{H}) .{ }^{13} \mathrm{C} \mathrm{NMR}\left(125 \mathrm{MHz}, \mathrm{CDCl}_{3}\right) \delta 208.0,141.0,128.5,128.3,126.1,45.2,30.1,29.8$.

Benzaldehyde (4h)<smiles>O=Cc1ccccc1</smiles>

$4 \mathrm{~h}$

The titled compound was synthesized according to the general procedure (Method III) using $\mathbf{2 h}$ (228 $\mathrm{mg}, 1.00$ mmol) as a substrate. The obtained crude material was purified by MPLC ( $n$-hexane/AcOEt $=1 / 0$ to $9 / 1)$ to give $\mathbf{4 h}$ (75 mg, 71\%) as colorless oil.

NMR spectra of the obtained product were consistent with the reported one. ${ }^{27}$

${ }^{1} \mathrm{H}$ NMR $\left(500 \mathrm{MHz}, \mathrm{CDCl}_{3}\right) \delta 10.03(\mathrm{~s}, 1 \mathrm{H}), 7.91-7.88(\mathrm{~m}, 2 \mathrm{H}), 7.66-7.62(\mathrm{~m}, 1 \mathrm{H}), 7.54(\mathrm{t}, J=7.7 \mathrm{~Hz}, 2 \mathrm{H}) .{ }^{13} \mathrm{C}$ NMR (125 MHz, $\left.\mathrm{CDCl}_{3}\right) \delta 192.4,136.4,134.5,129.8,129.0$.

Acetophenone (4i)<smiles>CC(=O)c1ccccc1</smiles>

$4 \mathbf{i}$

The titled compound was synthesized according to the general procedure (Method III) using $2 \mathbf{i}$ (242 $\mathrm{mg}, 1.00$ $\mathrm{mmol}$ ) as a substrate. The obtained crude material was purified by MPLC ( $n$-hexane/AcOEt $=1 / 0$ to $9 / 1)$ to give $4 \mathbf{i}$ (105 mg, 87\%) as colorless oil.

NMR spectra of the obtained product were consistent with the reported one. ${ }^{28}$ ${ }^{1} \mathrm{H}$ NMR $\left(500 \mathrm{MHz}, \mathrm{CDCl}_{3}\right) \delta 8.00-7.94$ (m, 2H), 7.59-7.55 (m, 1H), 7.51-7.44 (m, 2H), $2.62(3 \mathrm{H}, \mathrm{s}) .{ }^{13} \mathrm{C} \mathrm{NMR}$ $\left(125 \mathrm{MHz}, \mathrm{CDCl}_{3}\right) \delta 198.1,137.1,133.1,128.6,128.3,26.6$. 
<smiles>CC(C)(C)C(=O)c1ccccc1</smiles>

The titled compound was synthesized according to the general procedure (Method III) using $2 \mathbf{j}$ ( $284 \mathrm{mg}, 1.00$ mmol) as a substrate. The obtained crude material was purified by MPLC ( $n$-hexane/AcOEt $=1 / 0$ to 19/1) to give $4 \mathbf{j}$ (160 mg, 99\%) as colorless oil.

NMR spectra of the obtained product were consistent with the reported one. ${ }^{29}$

${ }^{1} \mathrm{H}$ NMR (500 MHz, $\mathrm{CDCl}_{3}$ ) $\delta$ 7.70-7.67 (m, 2H), 7.47-7.43 (m, 1H), 7.42-7.37 (m, 2H), 1.35 (s, 9H). ${ }^{13} \mathrm{C}$ NMR $\left(125 \mathrm{MHz}, \mathrm{CDCl}_{3}\right) \delta 209.3,138.6,130.8,128.1,127.8,44.2,28.0$.

4'-Methylacetophenone (4z)<smiles>CC(=O)c1ccc(C)cc1</smiles>

The titled compound was synthesized according to the general procedure (Method III) using $\mathbf{2 z}$ (256 mg, 1.00 mmol) as a substrate. The obtained crude material was purified by MPLC ( $n$-hexane/AcOEt $=1 / 0$ to $19 / 1)$ to give $\mathbf{4 z}$ (98 $\mathrm{mg}, 73 \%)$ as colorless oil.

NMR spectra of the obtained product were consistent with the reported one. ${ }^{30}$

${ }^{1} \mathrm{H}$ NMR (500 MHz, $\left.\mathrm{CDCl}_{3}\right) \delta$ 7.88-7.84 (m, 2H), 7.27-7.24 (m, 2H), $2.58(\mathrm{~s}, 3 \mathrm{H}), 2.42(\mathrm{~s}, 3 \mathrm{H}) .{ }^{13} \mathrm{C}$ NMR $(75$ $\left.\mathrm{MHz}, \mathrm{CDCl}_{3}\right) \delta 197.9,143.9,134.7,129.3,128.5,26.6,21.7$.

4'-Chloroacetophenone (4aa)<smiles>CC(=O)c1ccc(Cl)cc1</smiles>

4aa

The titled compound was synthesized according to the general procedure (Method III) using $2 \mathbf{2 a}$ (221 mg, 3.90 mmol) as a substrate. The obtained crude material was purified by MPLC ( $n$-hexane/AcOEt $=1 / 0$ to $23 / 2)$ to give 4aa (114 mg, 92\%) as colorless oil.

NMR spectra of the obtained product were consistent with the reported one. ${ }^{30}$

${ }^{1} \mathrm{H}$ NMR (500 MHz, $\left.\mathrm{CDCl}_{3}\right) \delta 7.92-7.88(\mathrm{~m}, 2 \mathrm{H}), 7.46-7.42(\mathrm{~m}, 2 \mathrm{H}), 2.59(\mathrm{~s}, 3 \mathrm{H}) .{ }^{13} \mathrm{C} \mathrm{NMR}\left(125 \mathrm{MHz}, \mathrm{CDCl}_{3}\right) \delta$ 196.9, 139.6, 135.5, 129.8, 128.9, 26.6. 
<smiles>CC(C)(C)C1CCC(=O)CC1</smiles>

The titled compound was synthesized according to the general procedure (Method III) using $2 \mathbf{a b}$ (276 mg, 1.00 mmol) as a substrate. The obtained crude material was purified by MPLC ( $n$-hexane/AcOEt $=1 / 0$ to 9/1) to give 4ab (120 mg, 78\%) as a colorless solid.

NMR spectra of the obtained product were consistent with the reported one. ${ }^{31}$

${ }^{1} \mathrm{H}$ NMR (500 MHz, $\mathrm{CDCl}_{3}$ ) $\delta$ 2.43-2.37 (m, 2H), 2.36-2.27 (m, 2H), 2.12-2.05 (m, 2H), 1.53-1.40 (m, 3H), 0.92 (s, 9H). ${ }^{13} \mathrm{C}$ NMR $\left(125 \mathrm{MHz}, \mathrm{CDCl}_{3}\right) \delta 212.7,46.7,41.4,32.5,27.6$.

$\alpha$-Tetralone (4ac, using $1 \mathrm{~g}$ of substrate $\mathbf{2 a c}$ )<smiles>O=C1CCCc2ccccc21</smiles>

To a mixture of $\mathbf{2 a c}(1.00 \mathrm{~g}, 3.73 \mathrm{mmol}), \mathbf{1}(85.8 \mathrm{mg}, 0.373 \mathrm{mmol}), \mathrm{NaHCO}_{3}(1.25 \mathrm{~g}, 14.9 \mathrm{mmol})$, and $\mathrm{H}_{2} \mathrm{O}(0.134$ $\mathrm{mL}, 7.45 \mathrm{mmol})$ in DCM $(75 \mathrm{~mL})$ was added PIFA $(3.53 \mathrm{~g}, 8.20 \mathrm{mmol})$. The resulting mixture was stirred at room temperature for $3 \mathrm{~h}$. The reaction was quenched with saturated aq. $\mathrm{Na}_{2} \mathrm{~S}_{2} \mathrm{O}_{3}$ and extracted with AcOEt. The organic layer was dried over $\mathrm{Na}_{2} \mathrm{SO}_{4}$, filtered and concentrated in vacuo to give a residue. The residue was purified by MPLC ( $n$-hexane/AcOEt $=1 / 0$ to 9/1) to give 4 ac $(417 \mathrm{mg}$, 77\%) of pale yellow oil.

NMR spectra of the obtained product were consistent with the reported one. ${ }^{32}$

${ }^{1} \mathrm{H}$ NMR $\left(500 \mathrm{MHz}, \mathrm{CDCl}_{3}\right) \delta 8.04(\mathrm{~d}, J=7.9 \mathrm{~Hz}, 1 \mathrm{H}), 7.47(\mathrm{t}, J=7.5 \mathrm{~Hz}, 1 \mathrm{H}), 7.31(\mathrm{t}, J=7.6 \mathrm{~Hz}, 1 \mathrm{H}), 7.27-7.24$ (m, 1H), $2.97(\mathrm{t}, J=6.1 \mathrm{~Hz}, 2 \mathrm{H}), 2.68-2.64(\mathrm{~m}, 2 \mathrm{H}), 2.18-2.11(\mathrm{~m}, 2 \mathrm{H}) .{ }^{13} \mathrm{C} \mathrm{NMR}\left(125 \mathrm{MHz}, \mathrm{CDCl}_{3}\right) \delta 198.5$, 144.5, 133.4, 132.7, 128.8, 127.2, 126.7, 39.2, 29.7, 23.3.

$(5 S, 8 R, 9 S, 10 S, 13 S, 14 S)$-10,13-Dimethyltetradecahydro-3H-cyclopenta $[a]$ phenanthrene-3,17(2H)-dione (4ad)

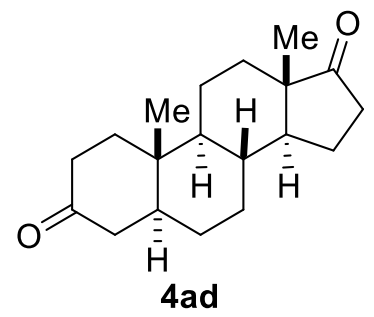

The titled compound was synthesized according to the general procedure (Method III) using 2ad (41.1 mg, 0.100 $\mathrm{mmol})$ as a substrate. The obtained crude material was purified by MPLC $(n$-hexane/AcOEt $=83 / 17)$ to give 4 ad (24.5 $\mathrm{mg}, 85 \%)$ as a colorless solid.

NMR spectra of the obtained product were consistent with the reported one. ${ }^{33}$ 
${ }^{1} \mathrm{H}$ NMR $\left(500 \mathrm{MHz}, \mathrm{CDCl}_{3}\right) \delta 2.50-2.35(\mathrm{~m}, 2 \mathrm{H}), 2.35-2.23(\mathrm{~m}, 2 \mathrm{H}), 2.15-2.00(\mathrm{~m}, 3 \mathrm{H}), 1.98-1.91(\mathrm{~m}, 1 \mathrm{H}), 1.88-$ $1.79(\mathrm{~m}, 2 \mathrm{H}), 1.74-1.66(\mathrm{~m}, 1 \mathrm{H}), 1.65-1.47(\mathrm{~m}, 3 \mathrm{H}), 1.46-1.23(\mathrm{~m}, 6 \mathrm{H}), 1.06-0.96(\mathrm{~m}, 4 \mathrm{H}), 0.89(\mathrm{~s}, 3 \mathrm{H}), 0.80$ (ddd, $J=12.3,10.4,4.2 \mathrm{~Hz}, 1 \mathrm{H}) .{ }^{13} \mathrm{C}$ NMR $\left(125 \mathrm{MHz}, \mathrm{CDCl}_{3}\right) \delta 221.0,211.7,53.9,51.2,47.8,46.6,44.6,38.5$, $38.1,35.9,35.8,35.0,31.5,30.6,28.6,21.8,20.7,13.8,11.5$.

\section{Synthesis of the substates}

Compounds $2 \mathbf{a},{ }^{34} \mathbf{2 b},{ }^{35} \mathbf{2 d},{ }^{35} \mathbf{2 e},{ }^{34} \mathbf{2 f},{ }^{34} \mathbf{2 h}-\mathbf{2 i},{ }^{37} \mathbf{2 j},{ }^{38} \mathbf{2 m},{ }^{39} \mathbf{2 o},{ }^{40} \mathbf{2 r},{ }^{41} \mathbf{2 s},{ }^{42} \mathbf{2 t},{ }^{39} \mathbf{2 v}-\mathbf{w},{ }^{39} \mathbf{2 x},{ }^{43} \mathbf{2 a a}{ }^{37}$ were prepared according to the reported procedures.

1-[(3-Phenylpropoxy)methyl]-4-(trifluoromethyl)benzene (6)

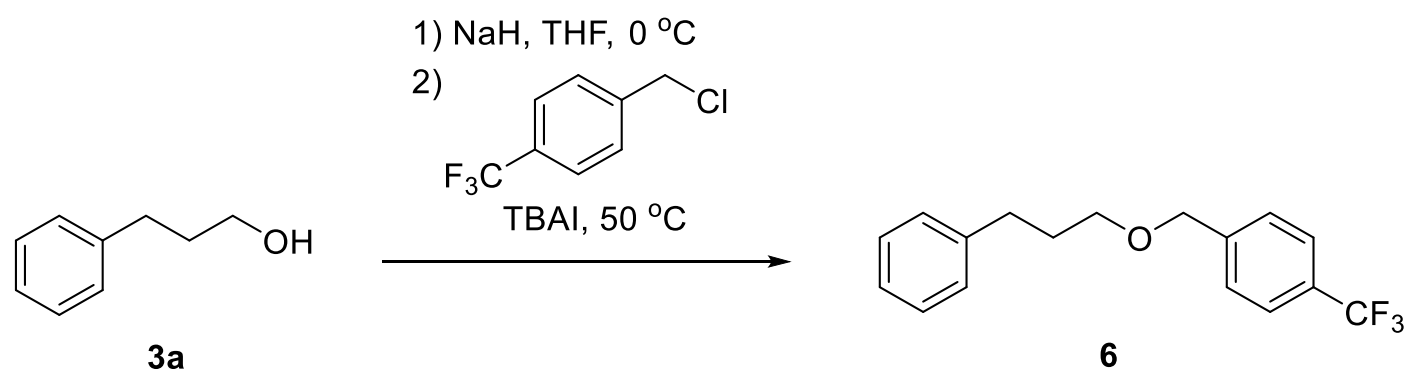

To a solution of 3a $(200 \mathrm{mg}, 1.47 \mathrm{mmol})$ in THF $(5.0 \mathrm{~mL})$ was added sodium hydride $(60 \%$ in mineral oil, $76.0 \mathrm{mg}$, $1.91 \mathrm{mmol}$ ) at $0{ }^{\circ} \mathrm{C}$, and the mixture was stirred at the same temperature for $10 \mathrm{~min}$. Then, 4-trifluoromethylbenzyl chloride $(238 \mu \mathrm{L}, 1.62 \mathrm{mmol})$ and TBAI $(54.2 \mathrm{mg}, 0.147 \mathrm{mmol})$ were added, and the mixture wasstirred at $50{ }^{\circ} \mathrm{C}$ for $24 \mathrm{~h}$. The reaction was quenched with water and extracted with AcOEt. The organic layer was dried over $\mathrm{Na}_{2} \mathrm{SO}_{4}$, filtered and concentrated in vacuo to give a residue. The residue was purified by MPLC ( $n$-hexane/AcOEt $=1 / 0$ to $9 / 1)$ to give $6(225 \mathrm{mg}, 52 \%)$ as colorless oil.

${ }^{1} \mathrm{H}$ NMR (300 MHz, $\left.\mathrm{CDCl}_{3}\right) \delta 7.61(\mathrm{~d}, J=8.1 \mathrm{~Hz}, 2 \mathrm{H}), 7.45(\mathrm{~d}, J=8.0 \mathrm{~Hz}, 2 \mathrm{H}), 7.31-7.24(\mathrm{~m}, 2 \mathrm{H}), 7.22-7.15(\mathrm{~m}$, $3 \mathrm{H}), 4.55(\mathrm{~s}, 2 \mathrm{H}), 3.51(\mathrm{t}, J=6.4 \mathrm{~Hz}, 2 \mathrm{H}), 2.73(\mathrm{t}, J=8.0 \mathrm{~Hz}, 2 \mathrm{H}), 2.02-1.90(\mathrm{~m}, 2 \mathrm{H}) .{ }^{13} \mathrm{C} \mathrm{NMR}(75 \mathrm{MHz}, \mathrm{CDCl} 3)$ $\delta 142.8,141.9,129.8$ (q, $J=32.2 \mathrm{~Hz}), 128.5,128.4,126.1,125.9,125.4$ (q, $J=3.8 \mathrm{~Hz}), 122.5,72.1,69.9,32.4$, 31.3. IR (neat) 2942, 2860, 1322, 1160, 1118, 1100, $1064 \mathrm{~cm}^{-1}$. HRMS (EI) $\mathrm{m} / z$ : $[\mathrm{M}]^{+}$Calcd for $\mathrm{C}_{17} \mathrm{H}_{17} \mathrm{~F}_{3} \mathrm{O}$ : 294.1232; Found 294.1230.

1-Methoxy-4-\{[(4-phenylbutan-2-yl)oxy]methyl\} benzene (2c)<smiles>CC(O)CCc1ccccc1</smiles><smiles>CCCCCC(C)OCCc1ccccc1</smiles>

To a mixture of 3c (1.50 g, $9.99 \mathrm{mmol})$, TBAI (369 mg, $0.999 \mathrm{mmol})$, and DIPEA (2.1 mL, $12 \mathrm{mmol}$ ) was added $\mathrm{PMBCl}(1.21 \mathrm{~mL}, 8.99 \mathrm{mmol})$. The resulting mixture was stirred at $140{ }^{\circ} \mathrm{C}$ for $1.5 \mathrm{~h}$. The reaction was quenched 
with water and extracted with AcOEt. The organic layer was washed with brine, dried over $\mathrm{Na}_{2} \mathrm{SO}_{4}$, filtered and concentrated in vacuo to give a residue. The residue was purified by MPLC ( $n$-hexane/AcOEt $=1 / 0$ to 97/3) to give 2c $(2.13 \mathrm{~g}, 88 \%)$ as colorless oil.

${ }^{1} \mathrm{H}$ NMR (300 MHz, $\left.\mathrm{CDCl}_{3}\right) \delta$ 7.35-7.27 (m, 4H), 7.25-7.17 (m, 3H), 6.98-6.88 (m, 2H), $4.56(\mathrm{~d}, J=11.5 \mathrm{~Hz}$, $1 \mathrm{H}), 4.42(\mathrm{~d}, J=11.3 \mathrm{~Hz}, 1 \mathrm{H}), 3.84(\mathrm{~s}, 3 \mathrm{H}), 3.62-3.49(\mathrm{~m}, 1 \mathrm{H}), 2.85-2.61(\mathrm{~m}, 2 \mathrm{H}), 2.01-1.88(\mathrm{~m}, 1 \mathrm{H}), 1.84-1.70$ $(\mathrm{m}, 1 \mathrm{H}), 1.26(\mathrm{~d}, J=6.1 \mathrm{~Hz}, 3 \mathrm{H}) .{ }^{13} \mathrm{C}$ NMR $\left(75 \mathrm{MHz}, \mathrm{CDCl}_{3}\right) \delta 159.1,142.5,131.1,129.3,128.5,128.4,125.7$, 113.8, 73.8, 70.0, 55.3, 38.5, 31.9, 19.7. IR (neat) 2930, 1510, 1245, $698 \mathrm{~cm}^{-1}$. HRMS (EI) $\mathrm{m} / \mathrm{z}$ : [M] $]^{+}$Calcd for $\mathrm{C}_{18} \mathrm{H}_{22} \mathrm{O}_{2}: 270.1620$; Found 270.1622 .

(8R,9S,13S,14S,17S)-17-[(4-Methoxybenzyl)oxy]-13-methyl-7,8,9,11,12,13,14,15,16,17-decahydro-6Hcyclopenta[ $[a]$ phenanthren-3-yl benzoate (2g)

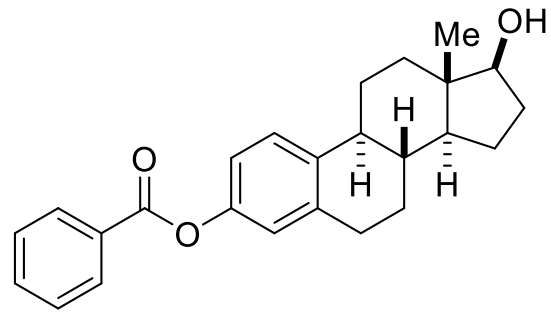

$3 \mathbf{g}$

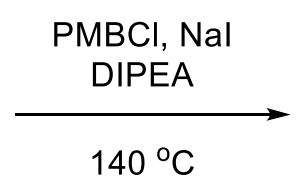

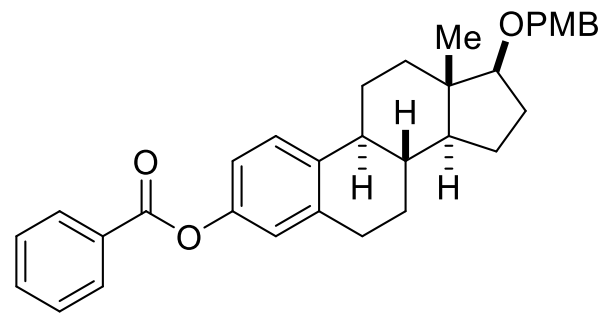

$2 \mathrm{~g}$

To a mixture of $\mathbf{3 g}$ ( $400 \mathrm{mg}, 1.06 \mathrm{mmol})$, sodium iodide ( $15.9 \mathrm{mg}, 0.106 \mathrm{mmol})$, and DIPEA (0.37 $\mathrm{mL}, 2.1 \mathrm{mmol})$ was added $\mathrm{PMBCl}(0.159 \mathrm{~mL}, 1.17 \mathrm{mmol})$. The resulting mixture was stirred at $140{ }^{\circ} \mathrm{C}$ for $20 \mathrm{~h}$. The reaction was quenched with water and extracted with AcOEt. The organic layer was washed with brine, dried over $\mathrm{Na}_{2} \mathrm{SO}_{4}$, filtered and concentrated in vacuo to give a residue. The residue was purified by MPLC ( $n$-hexane/AcOEt $=20 / 1)$ to give $2 \mathrm{~g}$ (185 $\mathrm{mg}, 55 \%)$ as a colorless solid.

M.p. ${ }^{118-120}{ }^{\circ} \mathrm{C} .{ }^{1} \mathrm{H}$ NMR $\left(500 \mathrm{MHz}, \mathrm{CDCl}_{3}\right) \delta 8.22-8.18(\mathrm{~m}, 2 \mathrm{H}), 7.66-7.61(\mathrm{~m}, 1 \mathrm{H}), 7.50(\mathrm{t}, J=7.6 \mathrm{~Hz}, 2 \mathrm{H})$, $7.34(\mathrm{~d}, J=8.5 \mathrm{~Hz}, 1 \mathrm{H}), 7.31-7.27(\mathrm{~m}, 2 \mathrm{H}), 6.97(\mathrm{dd}, J=8.5,2.6 \mathrm{~Hz}, 1 \mathrm{H}), 6.93(\mathrm{~d}, J=2.5 \mathrm{~Hz}, 1 \mathrm{H}), 6.91-6.87(\mathrm{~m}$, $2 \mathrm{H}), 4.52(\mathrm{~s}, 2 \mathrm{H}), 3.82(\mathrm{~s}, 3 \mathrm{H}), 3.50(\mathrm{t}, J=8.4 \mathrm{~Hz}, 1 \mathrm{H}), 2.96-2.83(\mathrm{~m}, 2 \mathrm{H}), 2.36-2.29(\mathrm{~m}, 1 \mathrm{H}), 2.24$ (td, $J=11.1$, $4.2 \mathrm{~Hz}, 1 \mathrm{H}), 2.10$ (dt, $J=12.8,3.5 \mathrm{~Hz}, 1 \mathrm{H}), 2.07-2.00(\mathrm{~m}, 1 \mathrm{H}), 1.89$ (ddt, $J=12.7,5.8,2.8 \mathrm{~Hz}, 1 \mathrm{H}$ ), 1.69 (dddd, $J$ $=12.3,9.5,7.0,3.3 \mathrm{~Hz}, 1 \mathrm{H}), 1.65-1.44(\mathrm{~m}, 3 \mathrm{H}), 1.43-1.30(\mathrm{~m}, 3 \mathrm{H}), 1.20$ (dddd, $J=12.4,10.9,7.1,3.3 \mathrm{~Hz}, 1 \mathrm{H})$, $0.88(\mathrm{~s}, 3 \mathrm{H}) .{ }^{13} \mathrm{C}$ NMR $\left(75 \mathrm{MHz}, \mathrm{CDCl}_{3}\right) \delta 165.5,159.0,148.7,138.4,138.2,133.5,131.4,130.2,129.8,128.9$, 128.6, 126.5, 121.6, 118.7, 113.7, 88.0, 71.4, 55.3, 50.3, 44.2, 43.4, 38.3, 38.0, 29.6, 28.1, 27.1, 26.3, 23.2, 11.8. IR (neat) 2933, 1732, 1512, 1245, $904 \mathrm{~cm}^{-1}$. HRMS (EI) $\mathrm{m} / z$ : $[\mathrm{M}]^{+}$Calcd for $\mathrm{C}_{33} \mathrm{H}_{36} \mathrm{O}_{4}: 496.2614$; Found 496.2615 .

1-Methoxy-4-[(oct-1-en-3-yloxy)methyl]benzene (2k)

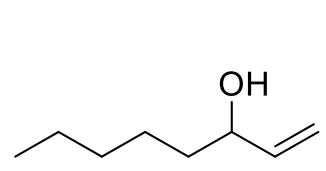

3k

$\mathrm{PMBCl}$,

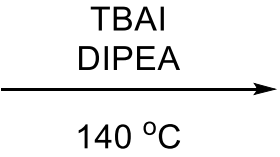

$140{ }^{\circ} \mathrm{C}$

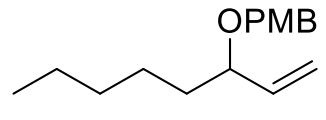

2k 
To a mixture of 3k (982 mg, $7.66 \mathrm{mmol})$, TBAI (236 mg, $0.639 \mathrm{mmol})$, and DIPEA (1.7 mL, $9.6 \mathrm{mmol})$ was added $\mathrm{PMBCl}(0.870 \mathrm{~mL}, 6.39 \mathrm{mmol})$. The resulting mixture was stirred at $140{ }^{\circ} \mathrm{C}$ for $2 \mathrm{~h}$. The reaction was quenched with water and extracted with AcOEt. The organic layer was washed with brine, dried over $\mathrm{Na}_{2} \mathrm{SO}_{4}$, filtered and concentrated in vacuo to give a residue. The residue was purified by column chromatography on silica gel ( $n$ hexane/AcOEt $=99 / 1)$ to give $2 \mathbf{k}(1.24 \mathrm{~g}, 78 \%)$ as colorless oil.

${ }^{1} \mathrm{H}$ NMR (300 MHz, CDCl 3 ) $\delta 7.32-7.25$ (m, 2H), 6.95-6.85 (m, 2H), 5.75 (dddd, $J=16.9,10.6,7.8,0.7 \mathrm{~Hz}, 1 \mathrm{H}$ ), 5.29-5.17 (m, 2H), $4.55(\mathrm{~d}, J=11.5 \mathrm{~Hz}, 1 \mathrm{H}), 4.30(\mathrm{~d}, J=11.5 \mathrm{~Hz}, 1 \mathrm{H}), 3.83(\mathrm{~s}, 3 \mathrm{H}), 3.76-3.67(\mathrm{~m}, 1 \mathrm{H}), 1.72-1.57$ (m, 2H), 1.57-1.20 (m, 6H), $0.89(\mathrm{t}, J=6.7 \mathrm{~Hz}, 3 \mathrm{H}) .{ }^{13} \mathrm{C} \mathrm{NMR}\left(75 \mathrm{MHz}, \mathrm{CDCl}_{3}\right) \delta 159.1,139.4,131.0,129.4$, $116.9,113.7,80.3,69.7,55.3,35.5,31.8,25.1,22.6,14.1$.

NMR spectra of the obtained product were consistent with the reported one. ${ }^{44}$

1-Methoxy-4-[(oct-2-yn-1-yloxy)methyl]benzene (2I)

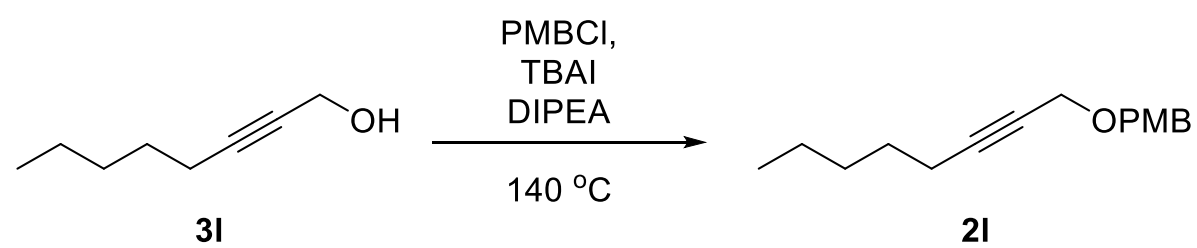

To a mixture of $3 \mathrm{l}$ (1.30 g, $10.3 \mathrm{mmol})$, TBAI (390 mg, $1.06 \mathrm{mmol})$, and DIPEA (2.7 mL, $16 \mathrm{mmol})$ was added $\mathrm{PMBCl}(1.40 \mathrm{~mL}, 10.3 \mathrm{mmol})$. The resulting mixture was stirred at $140^{\circ} \mathrm{C}$ for $2 \mathrm{~h}$. The reaction was quenched with water and extracted with AcOEt. The organic layer was washed with brine, dried over $\mathrm{Na}_{2} \mathrm{SO}_{4}$, filtered and concentrated in vacuo to give a residue. The residue was purified by MPLC ( $n$-hexane/AcOEt $=20 / 1)$ to give $\mathbf{2 l}$ $(2.59 \mathrm{~g}, 99 \%)$ as colorless oil.

${ }^{1} \mathrm{H}$ NMR (500 MHz, $\left.\mathrm{CDCl}_{3}\right) \delta$ 7.31-7.27 (m, 2H), 6.90-6.85 (m, 2H), $4.52(\mathrm{~s}, 2 \mathrm{H}), 4.12(\mathrm{t}, J=2.2 \mathrm{~Hz}, 2 \mathrm{H}), 3.80$ (s, $3 \mathrm{H}), 2.23(\mathrm{tt}, J=7.2,2.2 \mathrm{~Hz}, 2 \mathrm{H}), 1.57-1.49(\mathrm{~m}, 2 \mathrm{H}), 1.42-1.29(\mathrm{~m}, 4 \mathrm{H}), 0.91(\mathrm{t}, J=7.2 \mathrm{~Hz}, 3 \mathrm{H}) .{ }^{13} \mathrm{C}$ NMR $(125$ $\left.\mathrm{MHz}, \mathrm{CDCl}_{3}\right) \delta 159.3,129.8,113.8,87.2,75.9,70.9,57.4,55.3,31.1,26.4,22.2,16.8,14.0$. IR (neat) 2932, 1512, 1247, $752 \mathrm{~cm}^{-1}$. HRMS (EI) $\mathrm{m} / z$ : [M] $]^{+}$Calcd for $\mathrm{C}_{16} \mathrm{H}_{22} \mathrm{O}_{2}: 246.1620$; Found 246.1616.

2-(\{6-[(4-Methoxybenzyl)oxy]hexyl $\}$ oxy)pyrimidine (2n)

1) $\mathrm{NaH}, \mathrm{DMF}, 0^{\circ} \mathrm{C}$

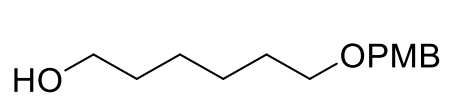

$3 n$
2) 2-chloropyrimidine, $80^{\circ} \mathrm{C}$

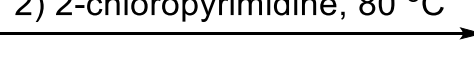

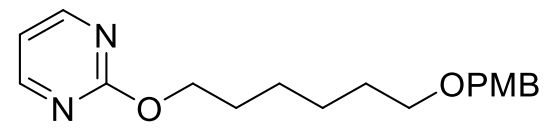

2n

To a solution of 3n $(250 \mathrm{mg}, 1.05 \mathrm{mmol})$ in DMF (3.0 mL) was added sodium hydride (60\% in mineral oil, 52.0 $\mathrm{mg}, 1.31 \mathrm{mmol})$ at $0{ }^{\circ} \mathrm{C}$ and stirred at the same temperature for $15 \mathrm{~min}$. Then, 2-chloropyrimidine (100 $\mathrm{mg}, 0.874$ mmol) was added, and the mixture was stirred at $80^{\circ} \mathrm{C}$ for $15 \mathrm{~h}$. The reaction was quenched with water and extracted with AcOEt. The organic layer was dried over $\mathrm{Na}_{2} \mathrm{SO}_{4}$, filtered and concentrated in vacuo to give a residue. The residue was purified by MPLC ( $n$-hexane/AcOEt $=1 / 0$ to $1 / 1)$ to give $2 \mathbf{n}(52.0 \mathrm{mg}, 19 \%)$ as pale yellow oil. 
${ }^{1} \mathrm{H}$ NMR $\left(300 \mathrm{MHz}, \mathrm{CDCl}_{3}\right) \delta 8.50(\mathrm{~d}, J=4.8 \mathrm{~Hz}, 2 \mathrm{H}), 7.29-7.23(\mathrm{~m}, 2 \mathrm{H}), 6.91(\mathrm{t}, J=4.8 \mathrm{~Hz}, 1 \mathrm{H}), 6.90-6.85(\mathrm{~m}$, 2H), $4.43(\mathrm{~s}, 2 \mathrm{H}), 4.34(\mathrm{t}, J=6.7 \mathrm{~Hz}, 2 \mathrm{H}), 3.80(\mathrm{~s}, 3 \mathrm{H}), 3.44(\mathrm{t}, J=6.6 \mathrm{~Hz}, 2 \mathrm{H}), 1.82$ (quintet, $J=6.8 \mathrm{~Hz}, 2 \mathrm{H}), 1.63$ (quintet, $J=6.8 \mathrm{~Hz}, 2 \mathrm{H}), 1.53-1.36(\mathrm{~m}, 4 \mathrm{H}) .{ }^{13} \mathrm{C} \mathrm{NMR}\left(75 \mathrm{MHz}, \mathrm{CDCl}_{3}\right) \delta 165.4,159.2,159.1,130.8,129.3$, 114.8, 113.8, 72.5, 70.1, 67.6, 55.3, 29.7, 28.8, 26.0, 25.8. IR (neat) 2933, 2855, 1423, 1244, 1088, 1031, $807 \mathrm{~cm}^{-1}$. HRMS (EI) $m / z:[\mathrm{M}]^{+}$Calcd for $\mathrm{C}_{18} \mathrm{H}_{24} \mathrm{~N}_{2} \mathrm{O}_{3}: 316.1787$; Found 316.1788 .

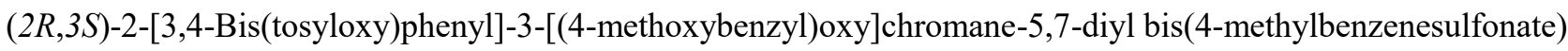
$(2 p)$<smiles>Oc1cc2c(c(OC(F)(F)F)c1)CC(O)[C@@H](c1ccc(OC(F)(F)F)c([18OH])c1)O2</smiles>

$3 p$

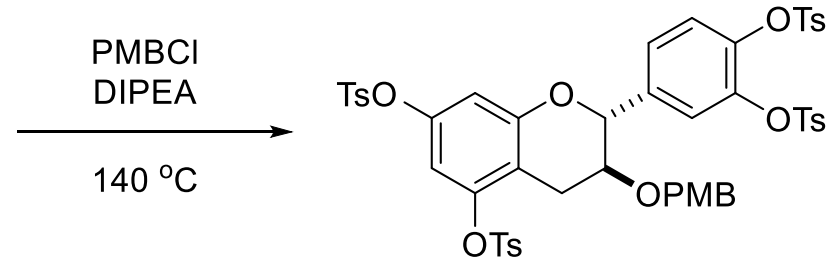

$2 p$

To a mixture of 3p (300 mg, $0.331 \mathrm{mmol})$ and DIPEA $(69.0 \mu \mathrm{L}, 0.397 \mathrm{mmol})$ was added PMBCl $(49.1 \mu \mathrm{L}, 0.364$ mmol). The resulting mixture was stirred at $140{ }^{\circ} \mathrm{C}$ for $1.5 \mathrm{~h}$. The reaction was quenched with water and extracted with AcOEt. The organic layer was washed with brine, dried over $\mathrm{Na}_{2} \mathrm{SO}_{4}$, filtered and concentrated in vacuo to give a residue. The residue was purified by MPLC ( $n$-hexane/AcOEt $=9 / 1$ to $2 / 3)$ to give $2 \mathbf{p}(185 \mathrm{mg}$, 55\%) as a colorless amorphous solid.

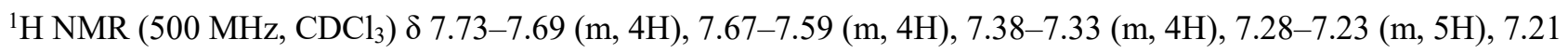
$(\mathrm{d}, J=2.1 \mathrm{~Hz}, 1 \mathrm{H}), 7.14(\mathrm{dd}, J=8.5,2.1 \mathrm{~Hz}, 1 \mathrm{H}), 6.98-6.92(\mathrm{~m}, 2 \mathrm{H}), 6.85-6.80(\mathrm{~m}, 2 \mathrm{H}), 6.46(\mathrm{~d}, J=2.3 \mathrm{~Hz}, 1 \mathrm{H})$, $6.31(\mathrm{~d}, J=2.4 \mathrm{~Hz}, 1 \mathrm{H}), 4.74(\mathrm{~d}, J=7.8 \mathrm{~Hz}, 1 \mathrm{H}), 4.28(\mathrm{~d}, J=11.5 \mathrm{~Hz}, 1 \mathrm{H}), 4.13(\mathrm{~d}, J=11.5 \mathrm{~Hz}, 1 \mathrm{H}), 3.79(\mathrm{~s}, 3 \mathrm{H})$, $3.55(\mathrm{td}, J=8.3,5.2 \mathrm{~Hz}, 1 \mathrm{H}), 2.88(\mathrm{dd}, J=16.8,5.2 \mathrm{~Hz}, 1 \mathrm{H}), 2.59$ (dd, $J=16.8,8.5 \mathrm{~Hz}, 1 \mathrm{H}), 2.47$ (s, 3H), 2.45 (s, $3 \mathrm{H}), 2.43(\mathrm{~s}, 3 \mathrm{H}), 2.43(\mathrm{~s}, 3 \mathrm{H}) .{ }^{13} \mathrm{C} \mathrm{NMR}\left(125 \mathrm{MHz}, \mathrm{CDCl}_{3}\right) \delta 159.5,154.8,148.3,148.2,146.1,145.8,141.2$, 141.1, 138.4, 132.4, 132.2, 132.14, 132.06, 130.1, 130.0, 129.81, 129.80, 129.4, 129.0, 128.6, 128.5, 128.4, 126.4, 124.2, 122.9, 114.2, 114.0, 109.6, 109.4, 79.1, 72.6, 71.2, 55.3, 25.9, 21.82, 21.79. IR (neat) 1595, 1372, 1174, 811, $547 \mathrm{~cm}^{-1}$. HRMS (ESI) $\mathrm{m} / z$ : [M+Na] $]^{+}$Calcd for $\mathrm{C}_{51} \mathrm{H}_{46} \mathrm{NaO}_{15} \mathrm{~S}_{4}$ : 1049.1612; Found 1049.1616.

1-Iodo-4-\{[(4-methoxybenzyl)oxy]methyl\}benzene (2q)<smiles>OCc1ccc(I)cc1</smiles>

$3 q$

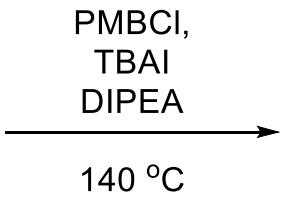

$140^{\circ} \mathrm{C}$<smiles>CCOCc1ccc(I)cc1</smiles>

2q

To a mixture of 3q (1.00 g, $4.27 \mathrm{mmol})$ and DIPEA (0.930 mL, $5.34 \mathrm{mmol})$ was added PMBCl (485 $\mu \mathrm{L}, 3.56$ mmol). The resulting mixture was stirred at $140{ }^{\circ} \mathrm{C}$ for $2 \mathrm{~h}$. The reaction was quenched with water and extracted with AcOEt. The organic layer was washed with brine, dried over $\mathrm{Na}_{2} \mathrm{SO}_{4}$, filtered and concentrated in vacuo to give a residue. The residue was purified by MPLC ( $n$-hexane/AcOEt $=99 / 1$ to $97 / 3)$ to give $2 q(1.21 \mathrm{~g}, 96 \%$ ) as a 
colorless amorphous solid.

${ }^{1} \mathrm{H}$ NMR (500 MHz, $\left.\mathrm{CDCl}_{3}\right)$ \& 7.69-7.65 (m, 2H), 7.29-7.25 (m, 2H), 7.12-7.09 (m, 2H), 6.92-6.87 (m, 2H), 4.48 (s, 2H), 4.46 (s, 2H), 3.81 (s, 3H). ${ }^{13} \mathrm{C}$ NMR (125 MHz, $\left.\mathrm{CDCl}_{3}\right) \delta 159.3,138.2,137.5,130.1,129.7,129.5,113.9$, 93.0, 71.9, 71.1, 55.3. IR (neat) 2853, 1510, 1249, $789 \mathrm{~cm}^{-1}$. HRMS (EI) $\mathrm{m} / \mathrm{z}$ : [M] $]^{+}$Calcd for $\mathrm{C}_{15} \mathrm{H}_{15} \mathrm{IO}_{2}: 354.0117$; Found 354.0119.

2-\{[(\{6-[(4-Methoxybenzyl)oxy]hexyl\}oxy)methoxy]methyl $\}$ naphthalene (2u)

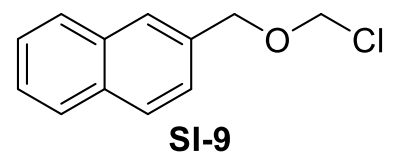

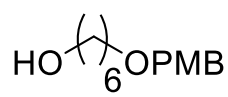

SI-7

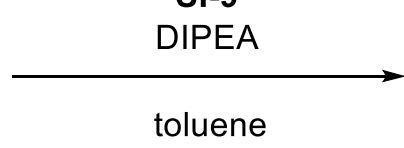

$80^{\circ} \mathrm{C}$

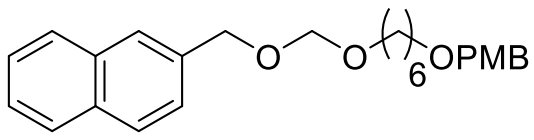

$2 u$

To a solution of SI-7 (300 mg, $1.26 \mathrm{mmol})$ and DIPEA $(1.32 \mathrm{~mL}, 7.55 \mathrm{mmol})$ in toluene $(3.0 \mathrm{~mL})$ was added SI-9 (520 mg, $2.52 \mathrm{mmol}$ ), and the mixture was stirred at $80^{\circ} \mathrm{C}$ for $5 \mathrm{~h}$. The reaction was quenched with water and extracted with AcOEt. The organic layer was dried over $\mathrm{Na}_{2} \mathrm{SO}_{4}$, filtered and concentrated in vacuo to give a residue. The residue was purified by MPLC ( $n$-hexane/AcOEt $=1 / 0$ to $7 / 3)$ to give $\mathbf{2} \mathbf{u}(284 \mathrm{mg}, 55 \%)$ as colorless oil.

${ }^{1} \mathrm{H}$ NMR (300 MHz, $\mathrm{CDCl}_{3}$ ) $\delta$ 7.85-7.77 (m, 4H), 7.50-7.42 (m, 3H), 7.28-7.20 (m, 2H), 6.90-6.82 (m, 2H), 4.79 (s, 2H), 4.76 (s, 2H), 4.41 (s, 2H), 3.77 (s, 3H), 3.60 (t, $J=6.6 \mathrm{~Hz}, 2 \mathrm{H}), 3.42$ (t, $J=6.6 \mathrm{~Hz}, 2 \mathrm{H}), 1.68-1.53$ (m, $4 \mathrm{H}), 1.43-1.32(\mathrm{~m}, 4 \mathrm{H}) .{ }^{13} \mathrm{C} \mathrm{NMR}\left(75 \mathrm{MHz}, \mathrm{CDCl}_{3}\right) \delta 159.1,135.5,133.3,133.0,130.8,129.3,128.2,127.9$, 127.7, 126.6, 126.2, 125.9, 113.8, 94.7, 72.6, 70.1, 69.4, 68.1, 55.3, 29.76, 29.75, 26.2, 26.1. IR (neat) 2932, 2856, 1510, 1245, 1034, $814 \mathrm{~cm}^{-1}$. HRMS (EI) $\mathrm{m} / z$ : [M] Calcd for $\mathrm{C}_{26} \mathrm{H}_{32} \mathrm{O}_{4}$ : 408.2301; Found 408.2300.

Benzyl 4-[(4-methoxybenzyl)oxy]piperidine-1-carboxylate (2y)

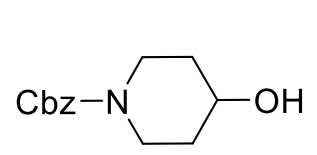

3y

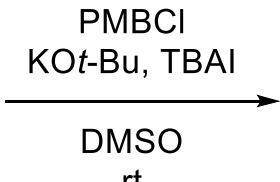

$\mathrm{rt}$

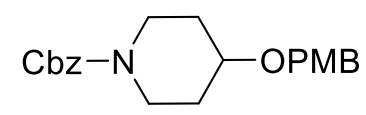

2y

To a mixture of $\mathbf{3 y}$ ( $200 \mathrm{mg}, 0.850 \mathrm{mmol}), \mathrm{KO} t-\mathrm{Bu}(114 \mathrm{mg}, 1.02 \mathrm{mmol})$, and TBAI (31.4 mg, $85.0 \mu \mathrm{mol})$ in DMSO $(3.3 \mathrm{~mL})$ was added PMBCl $(0.116 \mathrm{~mL}, 0.850 \mathrm{mmol})$. The resulting mixture was stirred at $\mathrm{rt}$ for $13 \mathrm{~h}$. The reaction was quenched with water and extracted with AcOEt. The organic layer was dried over $\mathrm{Na}_{2} \mathrm{SO}_{4}$, filtered and concentrated in vacuo to give a residue. The residue was purified by MPLC ( $n$-hexane/AcOEt $=4 / 1$ to 2/3) to give $\mathbf{2 y}(243 \mathrm{mg}, 80 \%)$ as colorless oil.

${ }^{1} \mathrm{H}$ NMR (300 MHz, CDCl $)$ d 7.40-7.29 (m, 5H), 7.29-7.23 (m, 2H), 6.91-6.85 (m, 2H), $5.13(\mathrm{~s}, 2 \mathrm{H}), 4.48(\mathrm{~s}$, 2H), 3.88-3.76 (m, 2H), 3.80 (s, 3H), 3.57 (tt, $J=7.8 \mathrm{~Hz}, 3.6 \mathrm{~Hz}, 1 \mathrm{H}), 3.22$ (ddd, $J=13.6 \mathrm{~Hz}, 8.7 \mathrm{~Hz}, 3.6 \mathrm{~Hz}, 2 \mathrm{H}$ ), 1.93-1.77 (m, 2H), 1.69-1.53 (m, 2H). ${ }^{13} \mathrm{C}$ NMR (75 MHz, $\left.\mathrm{CDCl}_{3}\right) \delta$ 159.2, 155.3, 136.9, 130.7, 129.1, 128.5, 128.0, 127.9, 113.9, 73.3, 69.6, 67.1, 55.3, 41.4, 31.0. IR (neat) 2946, 2859, 1692, 1427, 1223, 1083, $1028 \mathrm{~cm}^{-1}$. 
HRMS (EI) $m / z$ : [M] $]^{+}$Calcd for $\mathrm{C}_{21} \mathrm{H}_{25} \mathrm{NO}_{4}$ : 355.1784; Found 355.1780.

1-(\{[(cis-4-(tert-Butyl)cyclohexyl]oxy\}methyl)-4-methoxybenzene (2ab)

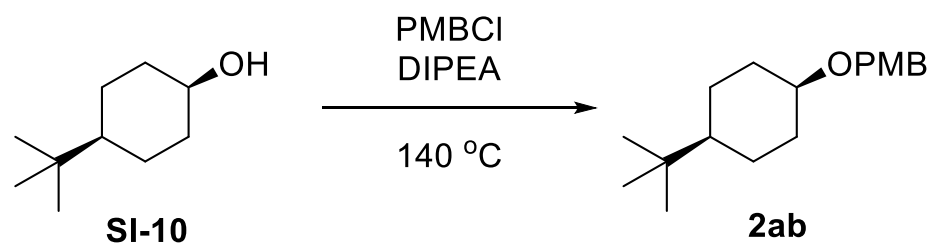

To a mixture of SI-10 (300 mg, $1.92 \mathrm{mmol})$ and DIPEA (0.40 mL, $2.3 \mathrm{mmol})$ was added PMBCl (0.285 mL, 2.11 mmol). The resulting mixture was stirred at $140{ }^{\circ} \mathrm{C}$ for $1.5 \mathrm{~h}$. The reaction was quenched with water and extracted with AcOEt. The organic layer was washed with brine, dried over $\mathrm{Na}_{2} \mathrm{SO}_{4}$, filtered and concentrated in vacuo to give a residue. The residue was purified by MPLC ( $n$-hexane/AcOEt $=1 / 0$ to $97 / 3)$ to give $2 \mathbf{a b}(211 \mathrm{mg}, 40 \%)$ as colorless oil.

${ }^{1} \mathrm{H}$ NMR $\left(500 \mathrm{MHz}, \mathrm{CDCl}_{3}\right) \delta$ 7.30-7.25 (m, 2H), 6.89-6.85 (m, 2H), $4.42(\mathrm{~s}, 2 \mathrm{H}), 3.79(\mathrm{~s}, 3 \mathrm{H}), 3.63-3.59(\mathrm{~m}$, 1H), 2.05-1.98 (m, 2H), 1.55-1.48 (m, 2H), 1.45-1.28 (m, 4H), 1.04-0.97 (m, 1H), $0.86(\mathrm{~s}, 9 \mathrm{H}) .{ }^{13} \mathrm{C}$ NMR $(75$ $\left.\mathrm{MHz}, \mathrm{CDCl}_{3}\right) \delta 158.9,131.7,128.9,113.7,72.0,69.0,55.3,48.1,32.6,30.5,27.6,21.6$. IR (neat) 2937, 1512, 1244, $1036 \mathrm{~cm}^{-1}$. HRMS (EI) $\mathrm{m} / z$ : [M] $]^{+}$Calcd for $\mathrm{C}_{18} \mathrm{H}_{28} \mathrm{O}_{2}: 276.2089$; Found 276.2087.

1-[(4-Methoxybenzyl)oxy]-1,2,3,4-tetrahydronaphthalene (2ac)<smiles>OC1CCCc2ccccc21</smiles>

SI-11
1) $\mathrm{NaH}, \mathrm{DMF}, \mathrm{rt}$ 2) $\mathrm{PMBCl}, 50^{\circ} \mathrm{C}$

To a solution of SI-11 (2.00 g, $13.5 \mathrm{mmol})$ in THF (30 mL) was added sodium hydride (60\% in mineral oil, 810 $\mathrm{mg}, 20.2 \mathrm{mmol})$ at $\mathrm{rt}$ and stirred at the same temperature for $15 \mathrm{~min}$. Then, PMBCl (1.64 $\mathrm{mL}, 12.1 \mathrm{mmol}) \mathrm{was}$ added, and the mixture was stirred at $50{ }^{\circ} \mathrm{C}$ for $15 \mathrm{~h}$. The reaction was quenched with water and extracted with AcOEt. The organic layer was dried over $\mathrm{Na}_{2} \mathrm{SO}_{4}$, filtered and concentrated in vacuo to give a residue. The residue was purified by MPLC ( $n$-hexane/AcOEt $=1 / 0$ to $23 / 2)$ to give 2 ac $(1.93 \mathrm{~g}, 59 \%)$ as colorless oil.

${ }^{1} \mathrm{H}$ NMR $\left(500 \mathrm{MHz}, \mathrm{CDCl}_{3}\right) \delta 7.35-7.31(\mathrm{~m}, 3 \mathrm{H}), 7.20-7.13(\mathrm{~m}, 2 \mathrm{H}), 7.11-7.07$ (m, 1H), 6.91-6.87 (m, 2H), 4.64 $(\mathrm{d}, J=11.5 \mathrm{~Hz}, 1 \mathrm{H}), 4.53(\mathrm{~d}, J=11.6 \mathrm{~Hz}, 1 \mathrm{H}), 4.51(\mathrm{t}, J=5.0 \mathrm{~Hz}, 1 \mathrm{H}), 3.81(\mathrm{~s}, 3 \mathrm{H}), 2.84(\mathrm{dt}, J=16.7,5.9 \mathrm{~Hz}$, 1H), 2.76-2.67 (m, 1H), 2.11-1.99 (m, 2H), 1.92 (dddd, $J=13.8,10.6,4.6,2.9 \mathrm{~Hz}, 1 \mathrm{H}), 1.79-1.70(\mathrm{~m}, 1 \mathrm{H}) .{ }^{13} \mathrm{C}$ NMR $\left(125 \mathrm{MHz} \mathrm{CDCl}_{3}\right) \delta 159.1,137.6,136.9,131.1,129.4,129.3,128.9,127.4,125.7,113.8,74.3,69.9,55.3$, 29.2, 27.9, 18.9. IR (neat) 2933, 1510, 1244, 1031, $738 \mathrm{~cm}^{-1}$. HRMS (EI) m/z: [M] Calcd for $\mathrm{C}_{18} \mathrm{H}_{20} \mathrm{O}_{2}: 268.1463$; Found 268.1465. 
(3R,5S,8R,9S,10S,13S,14S)-3-[(4-Methoxybenzyl)oxy]-10,13-dimethylhexadecahydro-17Hcyclopenta $[a]$ phenanthren-17-one (2ad)
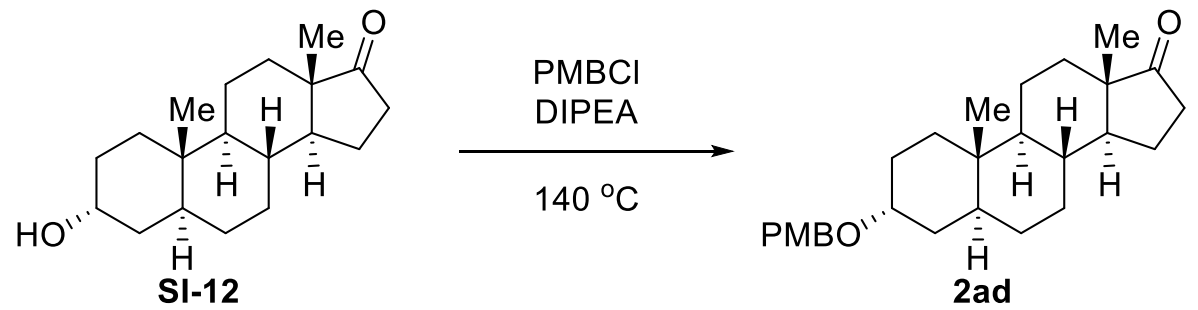

To a mixture of SI-12 (100 mg, $0.344 \mathrm{mmol})$ and DIPEA ( $72 \mu \mathrm{L}, 0.413 \mathrm{mmol})$ was added PMBCl (46.5 $\mu \mathrm{L}, 0.344$ mmol). The resulting mixture was stirred at $140{ }^{\circ} \mathrm{C}$ for $1.5 \mathrm{~h}$. The reaction was quenched with water and extracted with AcOEt. The organic layer was washed with brine, dried over $\mathrm{Na}_{2} \mathrm{SO}_{4}$, filtered and concentrated in vacuo to give a residue. The residue was purified by preparative TLC $(n$-hexane/AcOEt $=8 / 1)$ to give 2 ad $(81.0 \mathrm{mg}, 57 \%)$ as a colorless amorphous solid.

${ }^{1} \mathrm{H}$ NMR (300 MHz, $\left.\mathrm{CDCl}_{3}\right) \delta 7.32-7.22(\mathrm{~m}, 2 \mathrm{H}), 6.91-6.84(\mathrm{~m}, 2 \mathrm{H}), 4.45(\mathrm{~d}, J=11.7 \mathrm{~Hz}, 1 \mathrm{H}), 4.39$ (d, $J=11.7$ Hz, 1H), 3.80 (s, 3H), 3.64-3.59 (m, 1H), 2.48-2.37 (m, 1H), 2.13-1.99 (m, 1H), 1.99-1.89 (m, 1H), 1.89-1.72 (m, $3 \mathrm{H}), 1.71-1.12(\mathrm{~m}, 14 \mathrm{H}), 1.09-0.93(\mathrm{~m}, 1 \mathrm{H}), 0.88-0.77(\mathrm{~m}, 7 \mathrm{H}) .{ }^{13} \mathrm{C} \mathrm{NMR}\left(125 \mathrm{MHz}, \mathrm{CDCl}_{3}\right) \delta 221.6,158.9$, 131.4, 128.9, 113.7, 72.8, 69.3, 55.3, 54.3, 51.5, 47.8, 39.6, 36.1, 35.9, 35.1, 33.2, 32.7, 31.6, 30.8, 28.3, 25.5, 21.8, 20.1, 13.8, 11.4. IR (neat) 2922, 1735, 1512, 1245, $728 \mathrm{~cm}^{-1}$. HRMS (EI) $\mathrm{m} / z$ : [M] $]^{+}$Calcd for $\mathrm{C}_{27} \mathrm{H}_{38} \mathrm{O}_{3}: 410.2821$; Found 410.2818 .

[3-(Phenylmethoxy- $\left.d_{2}\right)$ propyl]benzene (5-D)

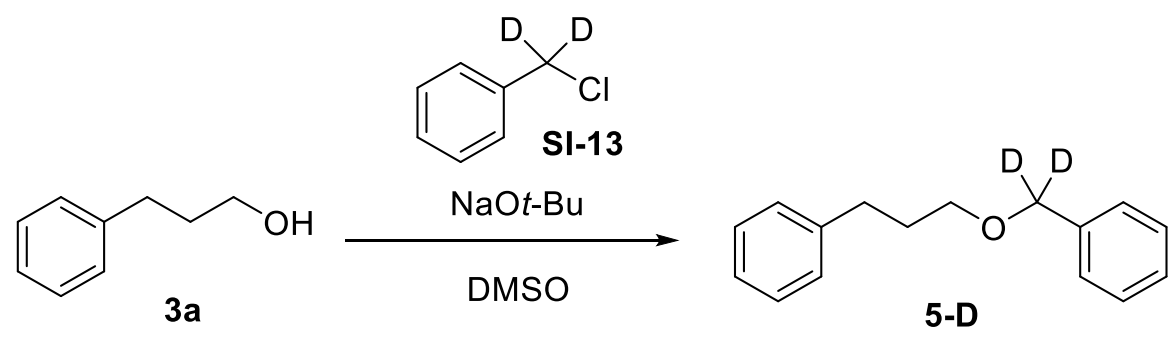

To a mixture of 3a (135 mg, $1.00 \mathrm{mmol})$ and $\mathrm{NaO} t$-Bu (115 mg, $1.20 \mathrm{mmol})$ in DMSO (2.0 mL) was added SI-13 $(0.131 \mathrm{~mL}, 1.10 \mathrm{mmol})$. The resulting mixture was stirred at $\mathrm{rt}$ for $3 \mathrm{~h}$. The reaction was quenched with water and extracted with AcOEt. The organic layer was dried over $\mathrm{Na}_{2} \mathrm{SO}_{4}$, filtered and concentrated in vacuo to give a residue. The residue was purified by column chromatography on silica gel $(n$-hexane/AcOEt $=5 / 1)$ to give 5-D (201 mg, 89\%) as colorless oil.

${ }^{1} \mathrm{H}$ NMR $\left(500 \mathrm{MHz}, \mathrm{CDCl}_{3}\right) \delta$ 7.39-7.33 (m, 4H), 7.32-7.25 (m, 3H), 7.21-7.16 (m, 3H), $3.49(\mathrm{t}, J=6.4 \mathrm{~Hz}, 2 \mathrm{H})$, 2.75-2.70 (m, 2H), 1.97-1.91 (m, 2H). ${ }^{13} \mathrm{C}$ NMR (75 MHz, $\left.\mathrm{CDCl}_{3}\right) \delta 142.1,138.5,128.6,128.5,128.4,127.8$, 127.7, 125.8, $72.3(\mathrm{t}, J=21.8 \mathrm{~Hz}), 69.5,32.5,31.5$. IR (neat) 2940, 2855, 1103, $695 \mathrm{~cm}^{-1}$. HRMS (EI) $\mathrm{m} / z:[\mathrm{M}]^{+}$ Calcd for $\mathrm{C}_{16} \mathrm{H}_{16} \mathrm{D}_{2} \mathrm{O}$ : 228.1483; Found 228.1485. 
1-Fluoro-3-[(3-phenylpropoxy)methylbenzene (SI-4)

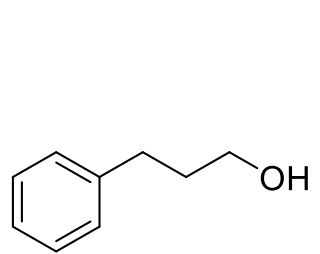

$3 \mathbf{a}$<smiles>Fc1cccc(CBr)c1</smiles>

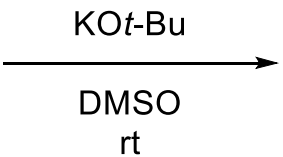

$\mathrm{rt}$<smiles>Fc1cccc(COCCCc2ccccc2)c1</smiles>

SI-4

To a mixture of 3a (200 mg, $1.47 \mathrm{mmol})$ and $\mathrm{KO} t$-Bu (247 mg, $2.20 \mathrm{mmol}$ ) in DMSO (3.3 mL) was added 3fluorobenzyl bromide $(0.330 \mathrm{~mL}, 2.20 \mathrm{mmol})$. The resulting mixture was stirred at $\mathrm{rt}$ for $15 \mathrm{~h}$. The reaction was quenched with water and extracted with AcOEt. The organic layer was dried over $\mathrm{Na}_{2} \mathrm{SO}_{4}$, filtered and concentrated in vacuo to give a residue. The residue was purified by MPLC ( $n$-hexane/AcOEt $=1 / 0$ to $7 / 3)$ to give SI-4 (221 mg, $62 \%)$ as colorless oil.

${ }^{1} \mathrm{H}$ NMR (300 MHz, $\left.\mathrm{CDCl}_{3}\right) \delta$ 7.35-7.26 (m, 3H), 7.22-7.15 (m, 3H), 7.13-7.04 (m, 2H), 7.02-6.93 (m, $\left.1 \mathrm{H}\right), 4.50$ $(\mathrm{s}, 2 \mathrm{H}), 3.50(\mathrm{t}, J=6.4 \mathrm{~Hz}, 2 \mathrm{H}), 2.77-2.69(\mathrm{~m}, 2 \mathrm{H}), 2.02-1.90(\mathrm{~m}, 2 \mathrm{H}) .{ }^{13} \mathrm{C} \mathrm{NMR}\left(75 \mathrm{MHz}, \mathrm{CDCl}_{3}\right) \delta 164.7$, 161.4, 141.9, 141.4 (d, $J=7.1 \mathrm{~Hz}), 129.9$ (d, $J=8.2 \mathrm{~Hz}), 128.5$ (d, J=9.9 Hz), 125.9, 123.0 (d, J=3.0 Hz), 114.5 $(\mathrm{d}, J=2.0 \mathrm{~Hz}), 114.2(\mathrm{~d}, J=2.7 \mathrm{~Hz}), 72.2$ (d, $J=1.8 \mathrm{~Hz}), 69.8,32.4,31.4$. IR (neat) 2939, 2857, 1590, 1450, 1103, $697 \mathrm{~cm}^{-1}$. HRMS (EI) $\mathrm{m} / z$ : [M] ${ }^{+}$Calcd for $\mathrm{C}_{16} \mathrm{H}_{17} \mathrm{FO}: 244.1263$; Found 244.1261. 


\section{References}

(1) Chen, G.; Fu, C. Ma, S. Tetrahedron 2006, 62, 4444-4452.

(2) Zhao, Q.; Curran, D. P.; Malacria, M.; Fensterbank, L.; Goddard, J-P.; Lacote, E. Chem. Eur. J. 2011, 17, 99119914.

(3) Rahaim Jr., R. J.; Maleczka, Jr., R. E. Org. Lett. 2011, 13, 584-587.

(4) Iinuma, M.; Moriyama, K.; Togo, H. Tetrahedron, 2013, 69, 2961-2970.

(5) Jiang, N.; Ragauskas, A. J. Org. Lett. 2005, 17, 3689-3692.

(6) Wang, Y.; Zhao, H.; Hu, Z.; Kimura, M.; Zhiqiang, Z.; Peng, L.; Hiratsuka, K. Synthesis, 2011, 287-291.

(7) Zhang, C-P.; Cai, J.; Zhou, C-B.; Wang, X-P.; Zheng, X.; Gu, Y-C.; Xiao, J-C. Chem. Commun. 2011, 47, 95169518.

(8) Shaikh, N. S.; Junge, K.; Beller, M. Org. Lett. 2007, 9, 5429-5432.

(9) Maytum, H. C.; Tavassoli, B.; Williams, J. M. J. Org. Lett. 2007, 9, 4387-4389.

(10) Balamurugan, R.; Gudla, V. Org. Lett. 2009, 11, 3116-3119.

(11) Liu, H-X.; Dang, Y-Q.; Yuan, Y-F.; Xu, Z-F.;Qiu, S-X.; Tan, H-B. Org. Lett. 2016, 18, 5584-5587.

(12) Cano, R.; Yus, M.; Ramón, D. J. Tetrahedron, 2011, 67, 8079-8085.

(13) Fernandes, J. L. N.; de Souza, M. C.; Brenelli, E. C. S.; Brenelli, J. A. Synthesis, 2009, 4058-4062.

(14) Felluga, F.; Forzato, C.; Ghelfi, F.; Nitti, P.; Pitacco, G.; Pagnoni U. M.; Roncaglia, F. Tetrahedron Asymm. 2007, 18, 527-536.

(15) Meyer, M. P.; Klinman, J. P. Tetrahedron Lett. 2008, 49, 3600-3603.

(16) Hong, Y.; Fang, T.; Li, M.; Shen, Z.; Hu, X.; Mo, W.; Hu, B.; Sun, N.; Jin, L. RSC. Adv. 2016, 6, 5190851913.

(17) Sawama, Y.; Masuda, M.; Asai, S.; Goto, R.; Nagata, S.; Nishimura, S.; Monguchi, Y.; Sajiki, H. Org. Lett. 2015, 17, 434-437.

(18) Everson, D. A.; Shrestha, R.; Weix, D. J. J. Am. Chem. Soc. 2010, 132, 920-921.

(19) Grotjahn, D. B.; Larsen, C. R.; Gustafson, J. L. Nair, R.; Sharma, A. J. Am. Chem. Soc. 2007, 129, 9592-9593.

(20) Tucker, J. W.; Narayanam, J. M. R.; Shah, P. S.; Stephenson, C. R. J. Chem. Commun. 2011, 47, 5040-5042.

(21) Corr, M. J.; Cormanich, R. A.; von Hahmann, C. N.; Bühl, M.; Cordes, D. B.; Slawin, A. M. Z.; O’Hagan, D. Org. Biomol. Chem. 2016, 14, 211-219.

(22) Green, R. A.; Jolley, K. E.; Al-Hadedi, A. A. M.; Pletcher, D.; Harrowven, D. C.; De Frutos, O.; Mateos, C.; Klauber, D. J.; Rincón, J. A.; Brown, R. C. E. Org. Lett. 2017, 19, 2050-2053.

(23) Yeom, C-E.; Kim, Y. J.; Lee, S. Y.; Shin, Y. J.; Kim, B. M. Tetrahedron, 2005, 61, 12227-12237.

(24) Sakamoto, R.; Inada, T.; Selvakumar, S.; Moteki, S. A.; Maruoka, K. Chem. Commun. 2016, 52, 3758-3761.

(25) Hoover, J. M.; Stahl, S. S. J. Am. Chem. Soc. 2011, 133, 16901-16910.

(26) Xu, G.; Leloux, S.; Zhang, P.; Suárez, J. M.; Zhang, Y.; Derat, E.; Ménand, M.; Bistri-Aslanoff, O.; Roland, S.; Leyssens, T.; Riant, O.; Sollogoub, M. Angew. Chem. Int. Ed. 2020, 59, 7591-7597.

(27) Jiang, N.; Ragauskas, A. J. Org. Lett. 2005, 7, 3689-3692.

(28) Yuan, Y.; Shi, X.; Liu, W. Synlett, 2011, 559-564.

(29) Shibuya, M.; Tomizawa, M.; Sasano, Y.; Iwabuchi, Y. J. Org. Chem. 2009, 74, 4619-4622. 
(30) Zhong, J-J.; To, W-P.; Liu, Y.; Lu, W.; Che, C-M. Chem. Sci. 2019, 10, 4883-4889.

(31) Guan, B.; Xing, D.; Cai, G.; Wan, X.; Yu, N.; Fang, Z.; Yang, L.; Shi, Z. J. Am. Chem. Soc. 2005, 127, 1800418005.

(32) Li, P.; Wang, Y.; Wang, X.; Wang, Y.; Liu, Y.; Huang, K.; Hu, J.; Duan, L.; Hu, C.; Liu, J. J. Org. Chem. 2020, $85,3101-3109$.

(33) Sun, J.; Dong, Y.; Cao, L.; Wang, X.; Wang, S.; Hu, Y. J. Org. Chem. 2004, 69, 8932-8934.

(34) Hamada, S.; Sugimoto, K.; Iida, M.; Furuta, T. Tetrahedron. Lett. 2019, 60, 151277.

(35) Kern, N.; Dombray, T.; Blanc, A.; Weibel, J-M.; Pale, P. J. Org. Chem. 2012, 77, 9227-9235.

(36) Yamada, K.; Fujita, H.; Kitamura, M.; Kunishima, M. Synthesis, 2013, 45, 2989-2997.

(37) Shen, Z.; Chen, M.; Fang, T.; Li, M.; Mo, W.; Hu, B.; Sun, N.; Hu, X. Tetrahedron. Lett. 2015, 56, $2768-2772$.

(38) Gathirwa, J. W.; Maki, T. Tetrahedron 2012, 68, 370-375.

(39) Hong, Y.; Fang, T.; Li, M.; Shen, Z.; Hu, X.; Mo, W.; Hu, B.; Sun, B.; Jin, L. RSC Adv. 2016, 6, 51908-51913.

(40) Jaschinski, T.; Hiersemann, M. Org. Lett. 2012, 14, 4114-4117.

(41) Ahn, D. K.; Kang, Y. W.; Woo, S. K. J. Org. Chem. 2019, 84, 3612-3623.

(42) Ilangovan, A.; Anandhan, K.; Kaushik, M. P. Tetrahedron. Lett. 2015, 56, 1080-1084.

(43) Green, R. A.; Jolley, K. E.; Al-Hadedi, A. A. M.; Pletcher, D.; Harrowven, D. C.; De Frutos, O.; Mateos, C.; Klauber, D. J.; Rincón, J. A.; Brown, R. C. D. Org. Lett. 2017, 19, 2050-2053.

(44) Yatsumonji, Y.; Ishida, Y.; Tsubouchi, A.; Takeda, T. Org. Lett. 2007, 9, 4603-4606. 
${ }^{1} \mathrm{H}$, and ${ }^{13} \mathrm{C}$ NMR spectra

${ }^{1} \mathrm{H}$ NMR spectrum in $\mathrm{CDCl}_{3}(500 \mathrm{MHz})$

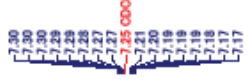

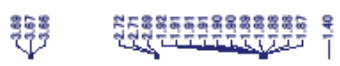

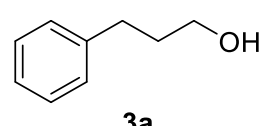

3a

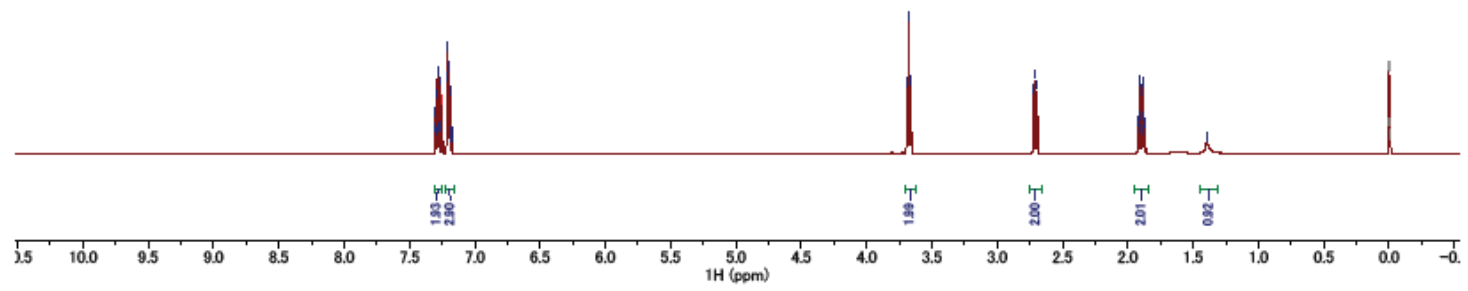

${ }^{13} \mathrm{C}$ NMR spectrum in $\mathrm{CDCl}_{3}(125 \mathrm{MHz})$
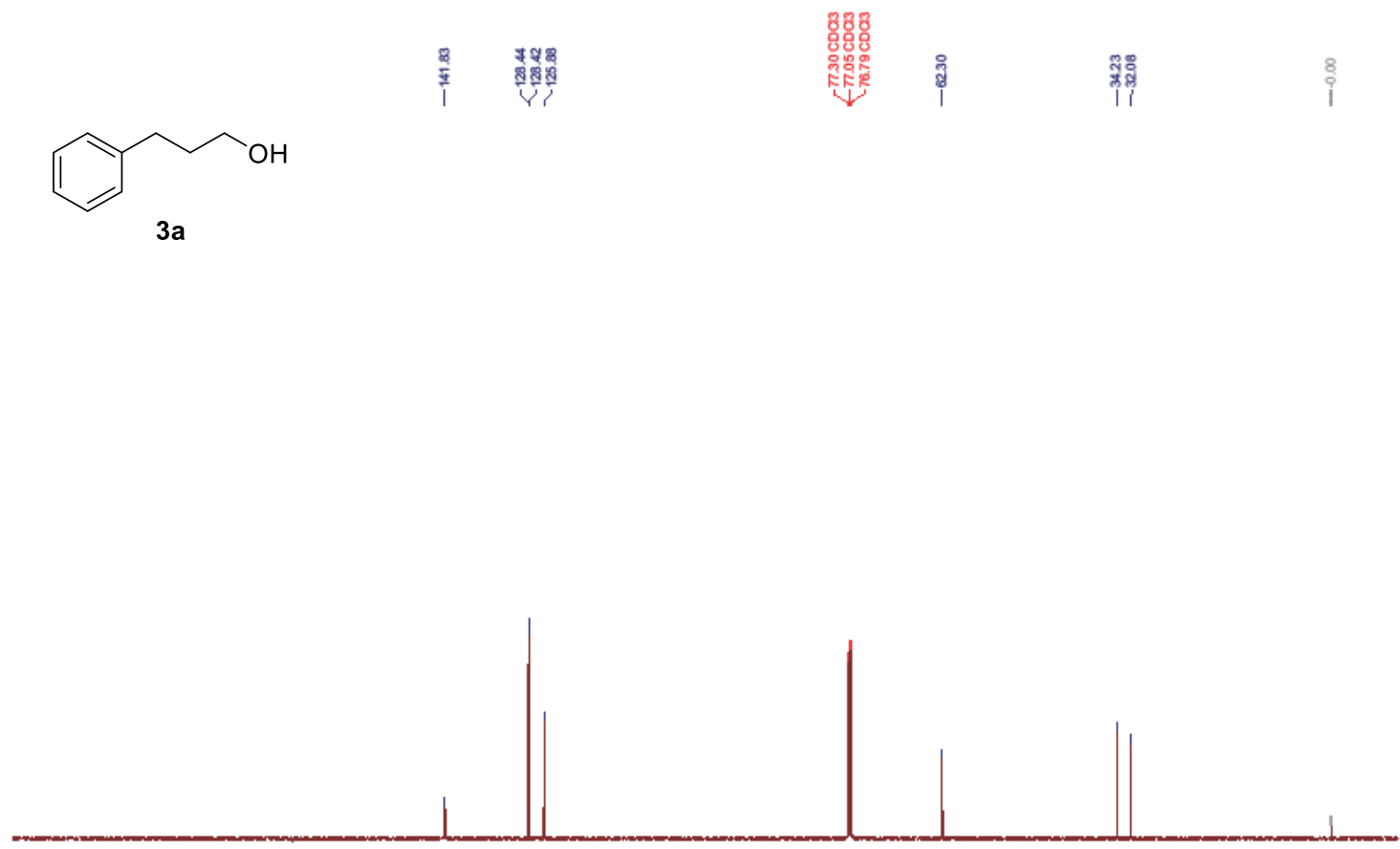

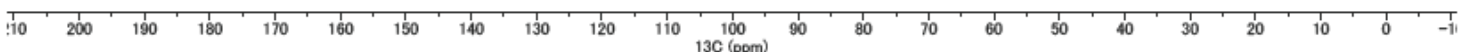


${ }^{1} \mathrm{H}$ NMR spectrum in $\mathrm{CDCl}_{3}(500 \mathrm{MHz})$

\section{:}

$x_{7} \mathrm{OH}$

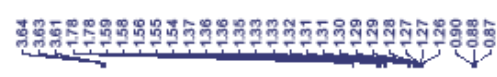

3b

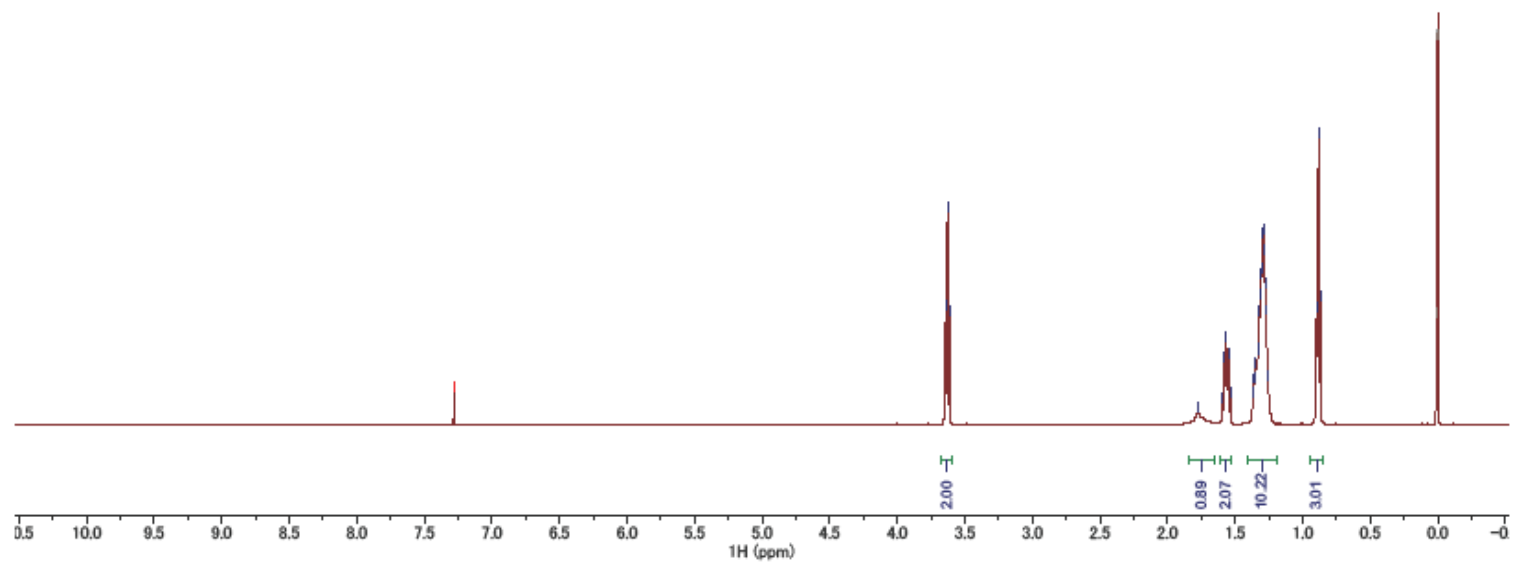

${ }^{13} \mathrm{C}$ NMR spectrum in $\mathrm{CDCl}_{3}(125 \mathrm{MHz})$

$\mathrm{X}_{7} \mathrm{OH}$

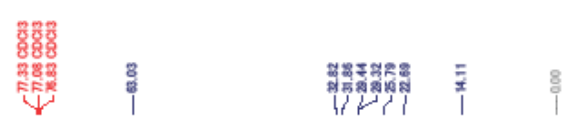

3b

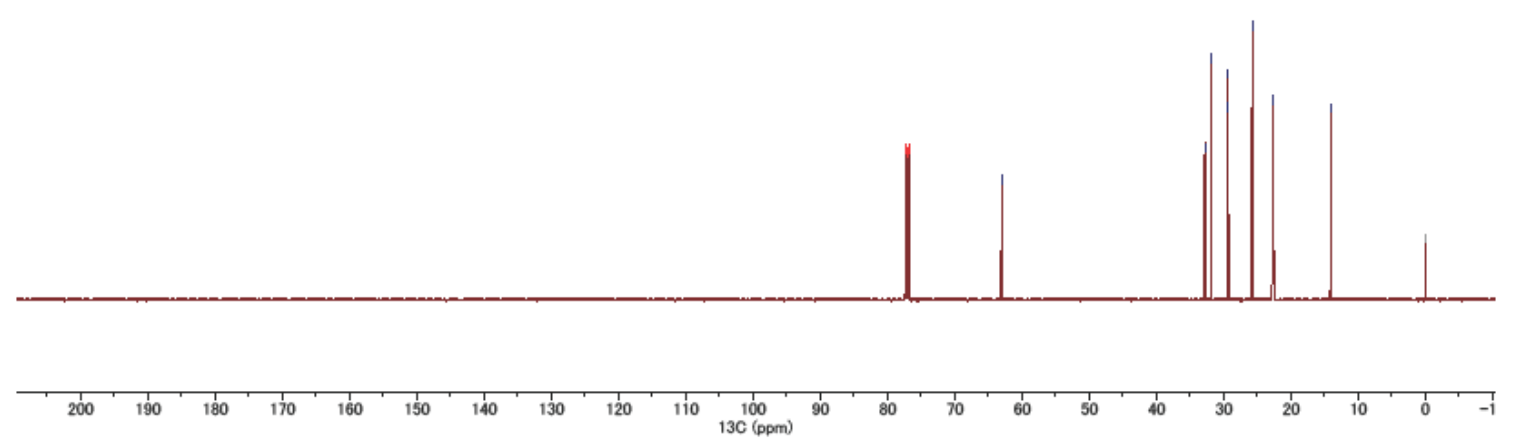


${ }^{1} \mathrm{H}$ NMR spectrum in $\mathrm{CDCl}_{3}(500 \mathrm{MHz})$
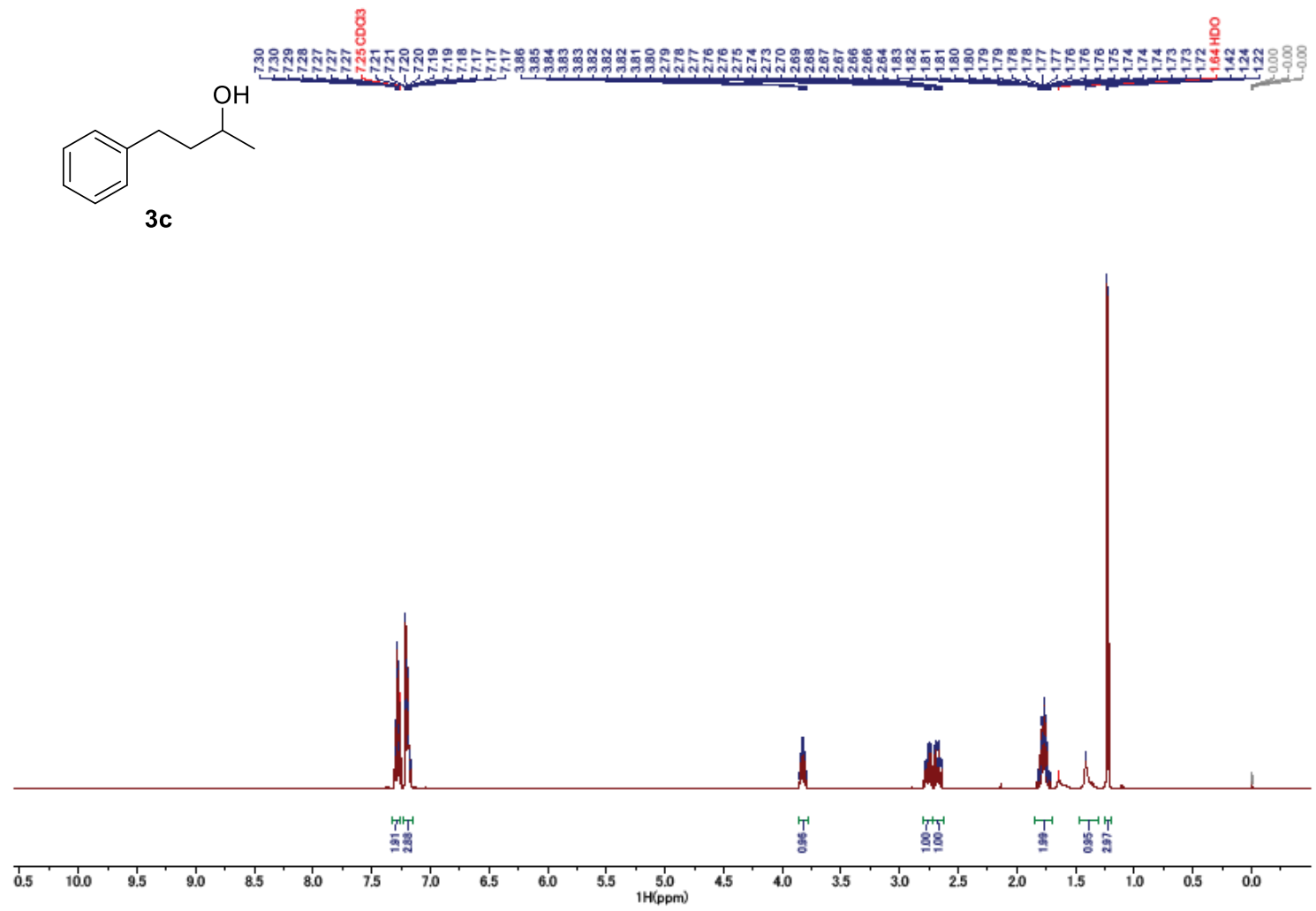

${ }^{13} \mathrm{C}$ NMR spectrum in $\mathrm{CDCl}_{3}(125 \mathrm{MHz})$
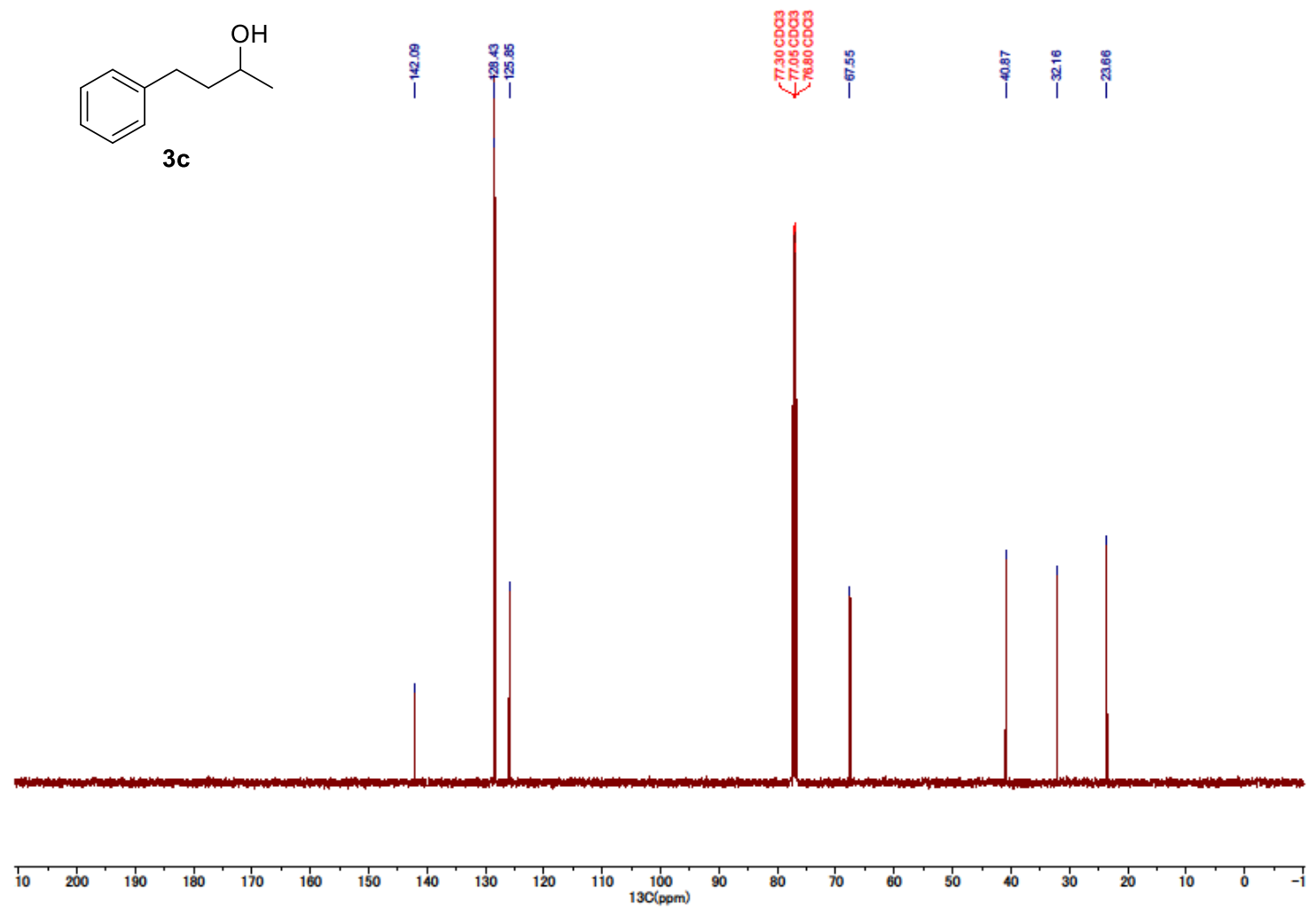

31 
${ }^{1} \mathrm{H}$ NMR spectrum in $\mathrm{CDCl}_{3}(500 \mathrm{MHz})$
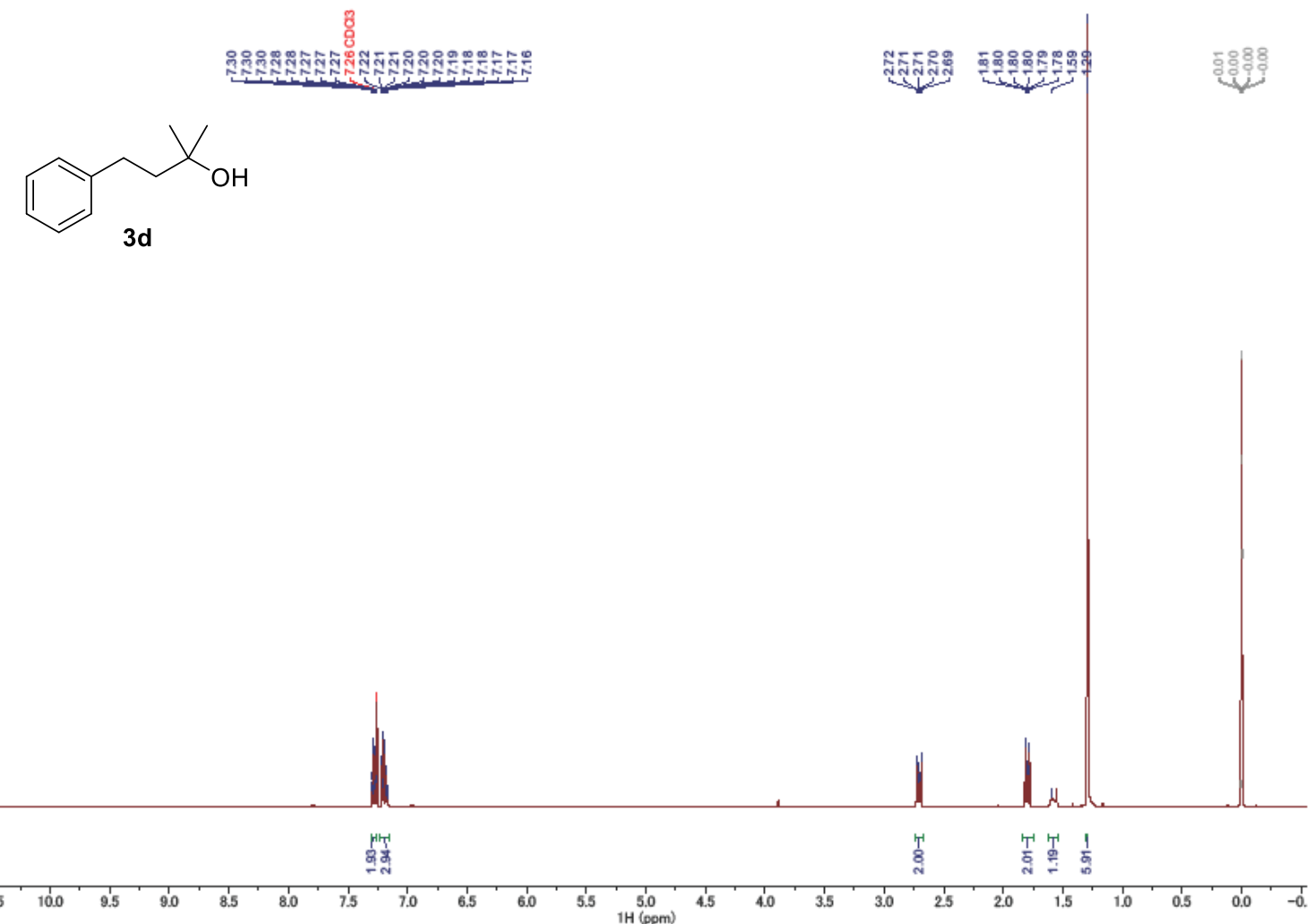

${ }^{13} \mathrm{C}$ NMR spectrum in $\mathrm{CDCl}_{3}(75 \mathrm{MHz})$<smiles>CC(C)(O)CCc1ccccc1</smiles><smiles>C1CCCC1</smiles>
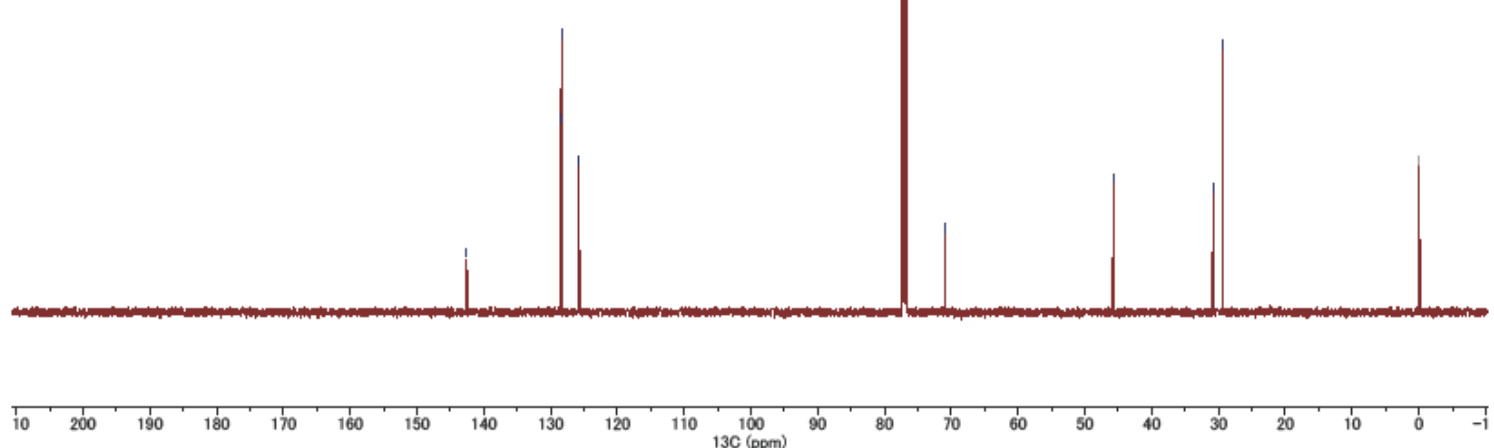
${ }^{1} \mathrm{H}$ NMR spectrum in $\mathrm{CDCl}_{3}(500 \mathrm{MHz})$

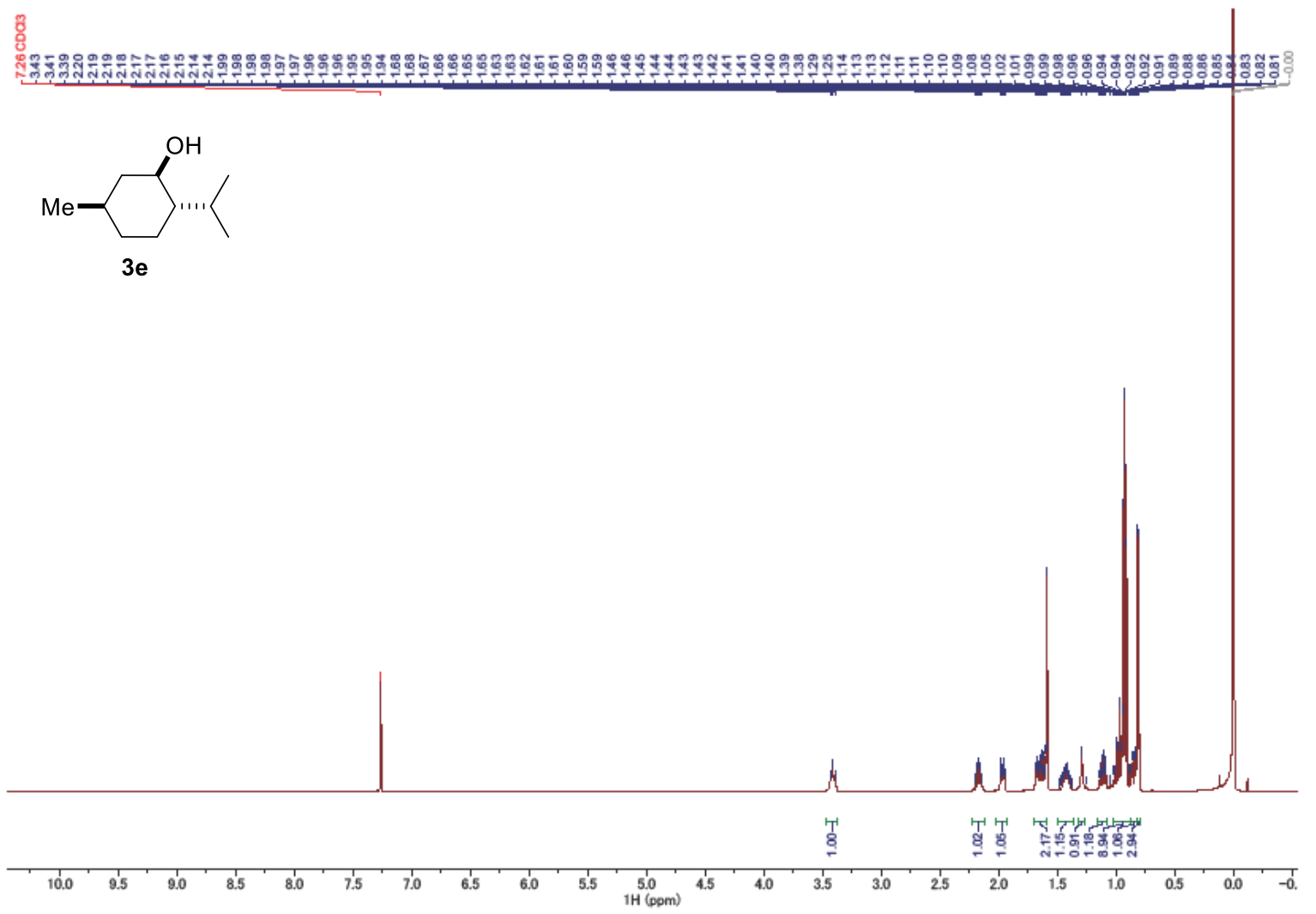

${ }^{13} \mathrm{C}$ NMR spectrum in $\mathrm{CDCl}_{3}(125 \mathrm{MHz})$
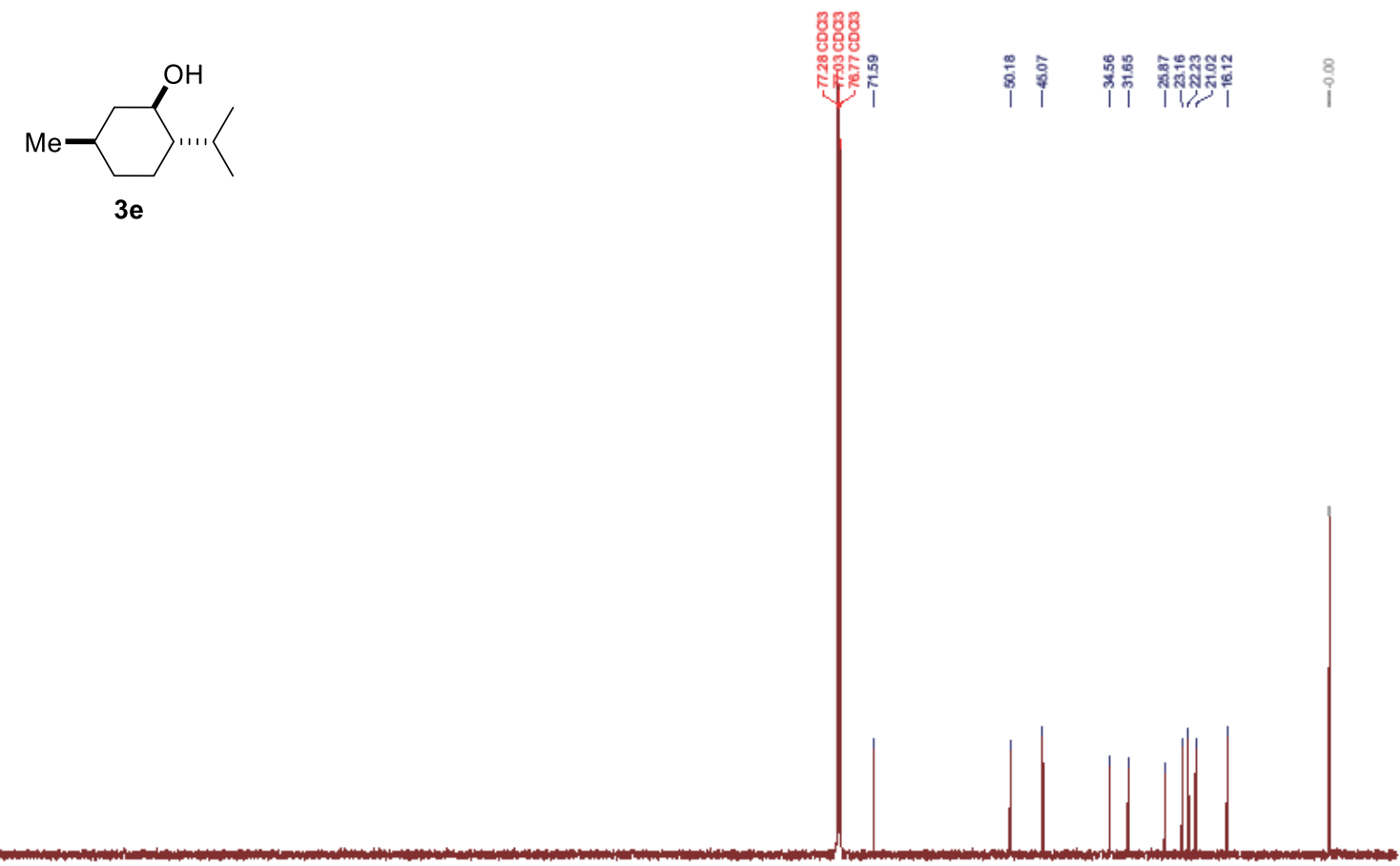

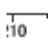
$110{ }_{13 c(0)}^{100}$ 
${ }^{1} \mathrm{H}$ NMR spectrum in $\mathrm{CDCl}_{3}(500 \mathrm{MHz})$
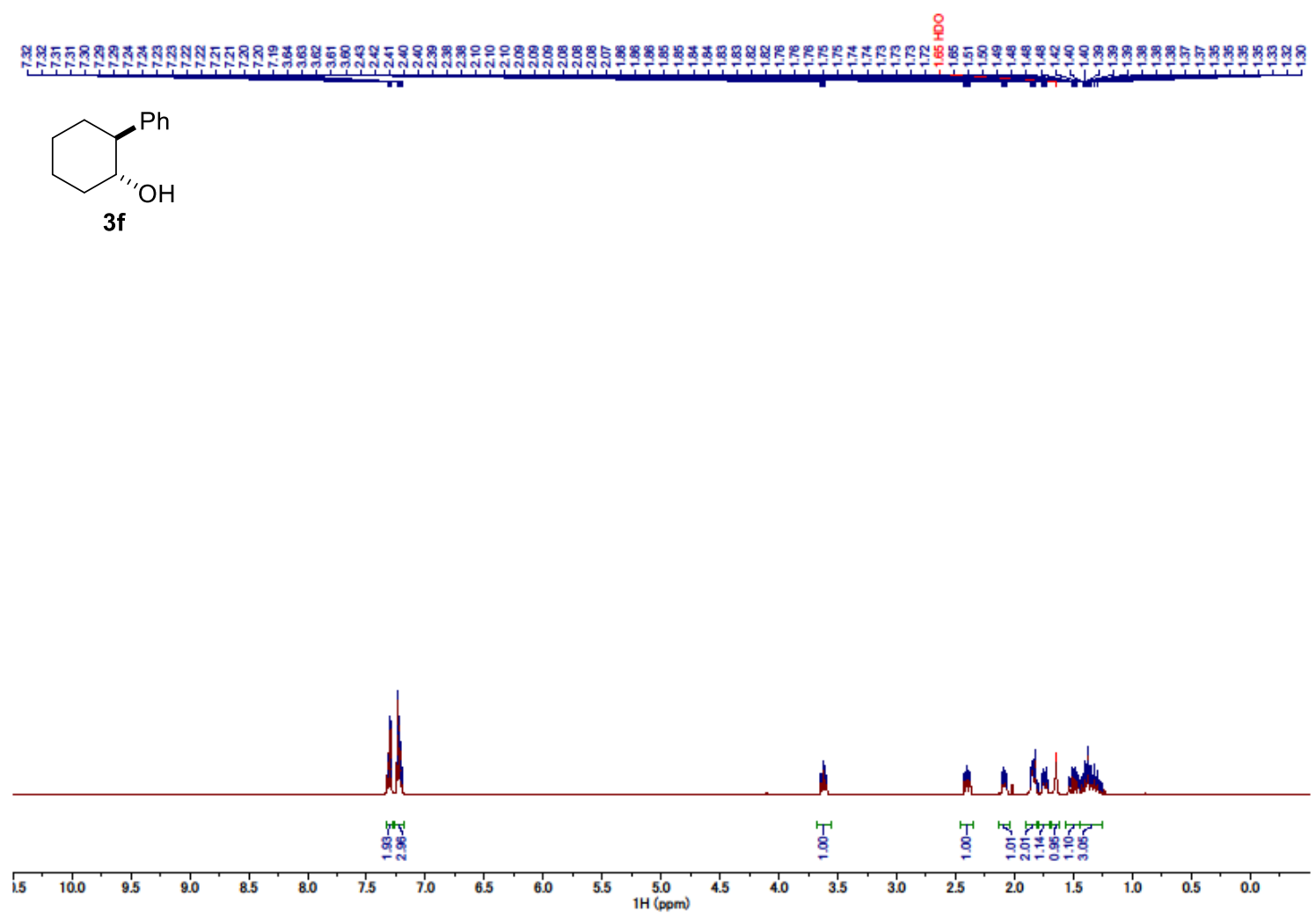

${ }^{13} \mathrm{C}$ NMR spectrum in $\mathrm{CDCl}_{3}(125 \mathrm{MHz})$

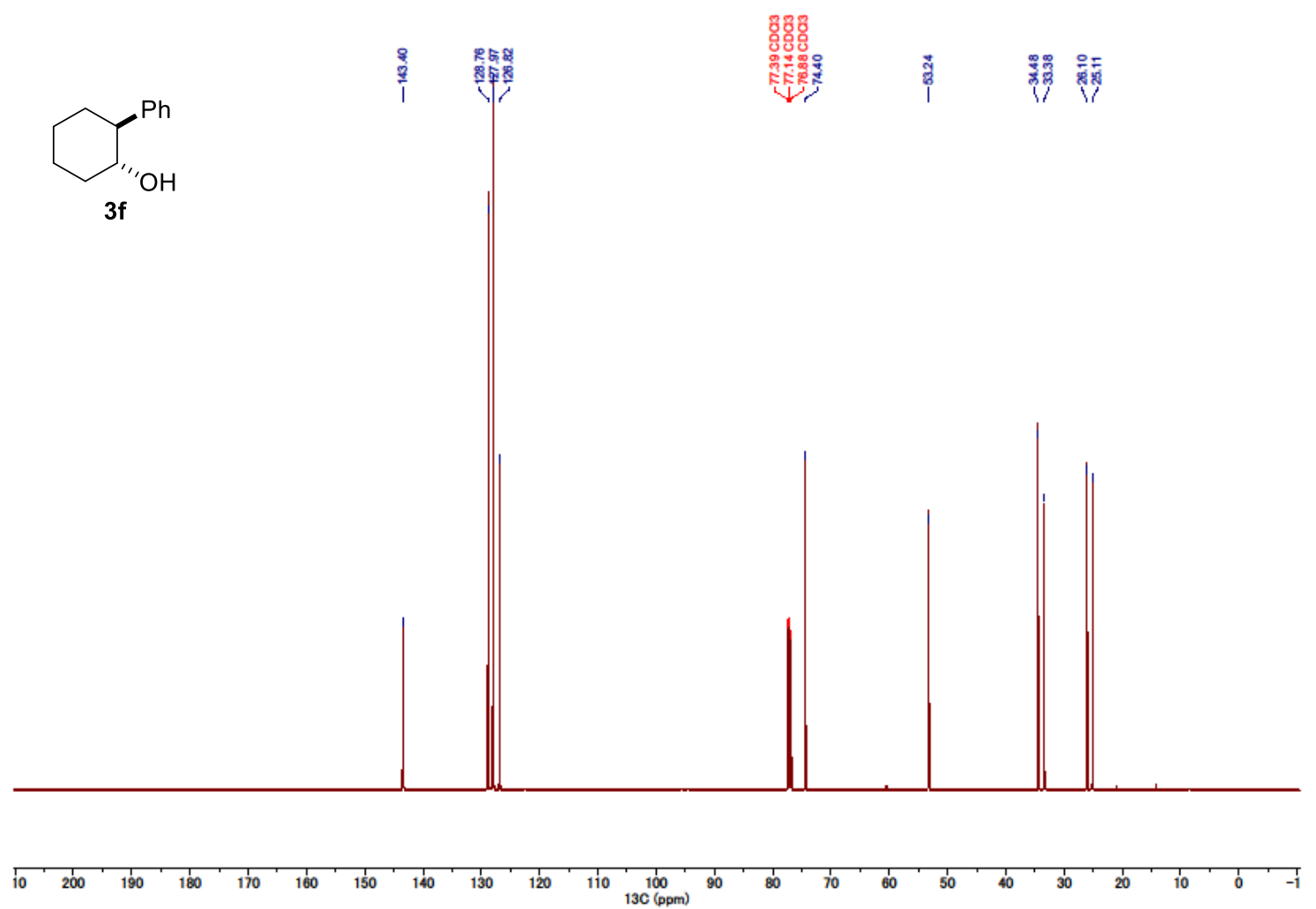


${ }^{1} \mathrm{H}$ NMR spectrum in $\mathrm{CDCl}_{3}(300 \mathrm{MHz})$

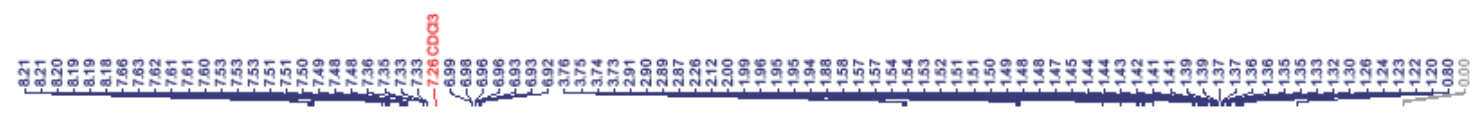<smiles>CC(C)(C)Oc1ccc2c(c1)CC[C@H]1C3CCC(C)(O)[C@@]3(O)CC[C@H]21</smiles>

$3 g$

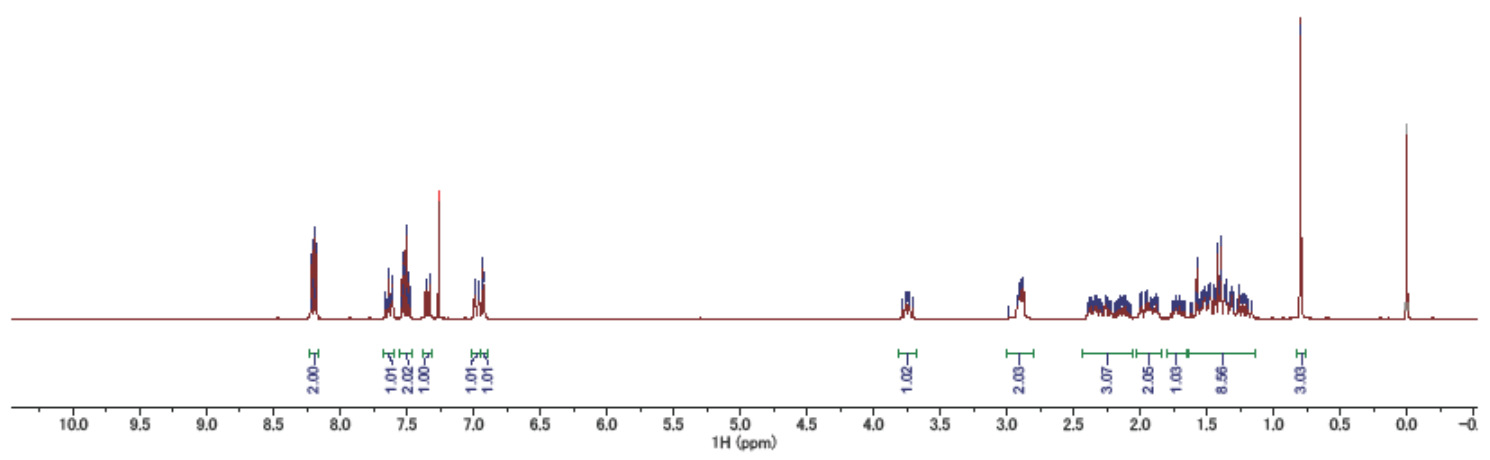

${ }^{13} \mathrm{C}$ NMR spectrum in $\mathrm{CDCl}_{3}(75 \mathrm{MHz})$

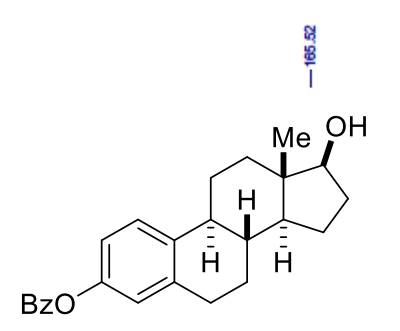

$3 \mathrm{~g}$

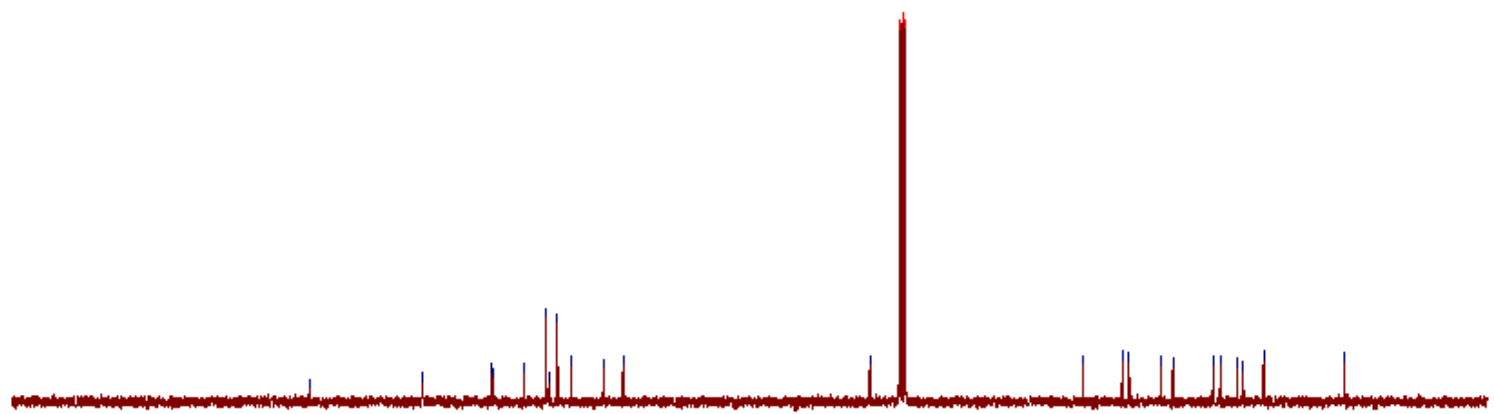


${ }^{1} \mathrm{H}$ NMR spectrum in $\mathrm{CDCl}_{3}(500 \mathrm{MHz})$
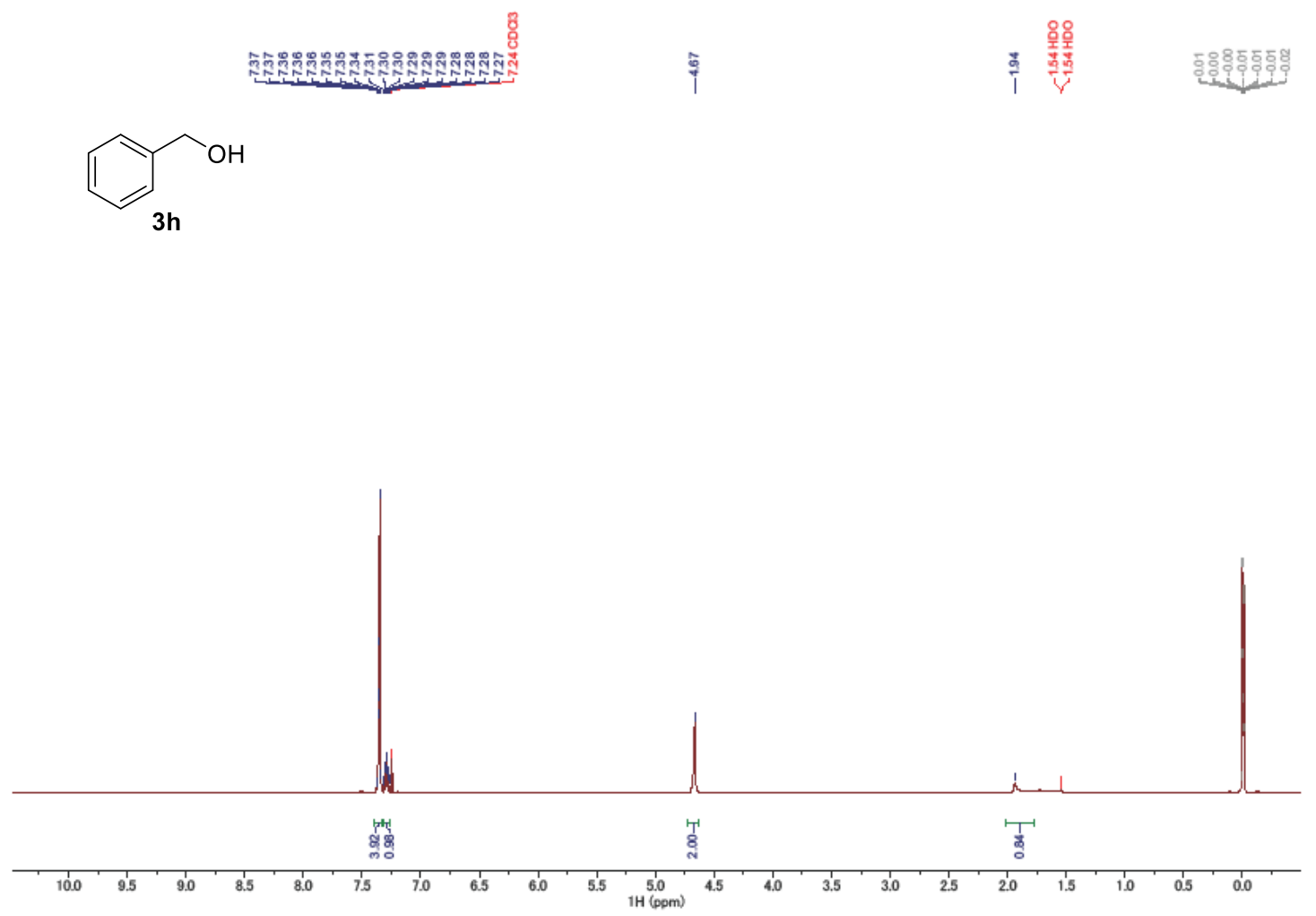

${ }^{13} \mathrm{C}$ NMR spectrum in $\mathrm{CDCl}_{3}(125 \mathrm{MHz})$<smiles>OCc1cccc[15c]1</smiles>
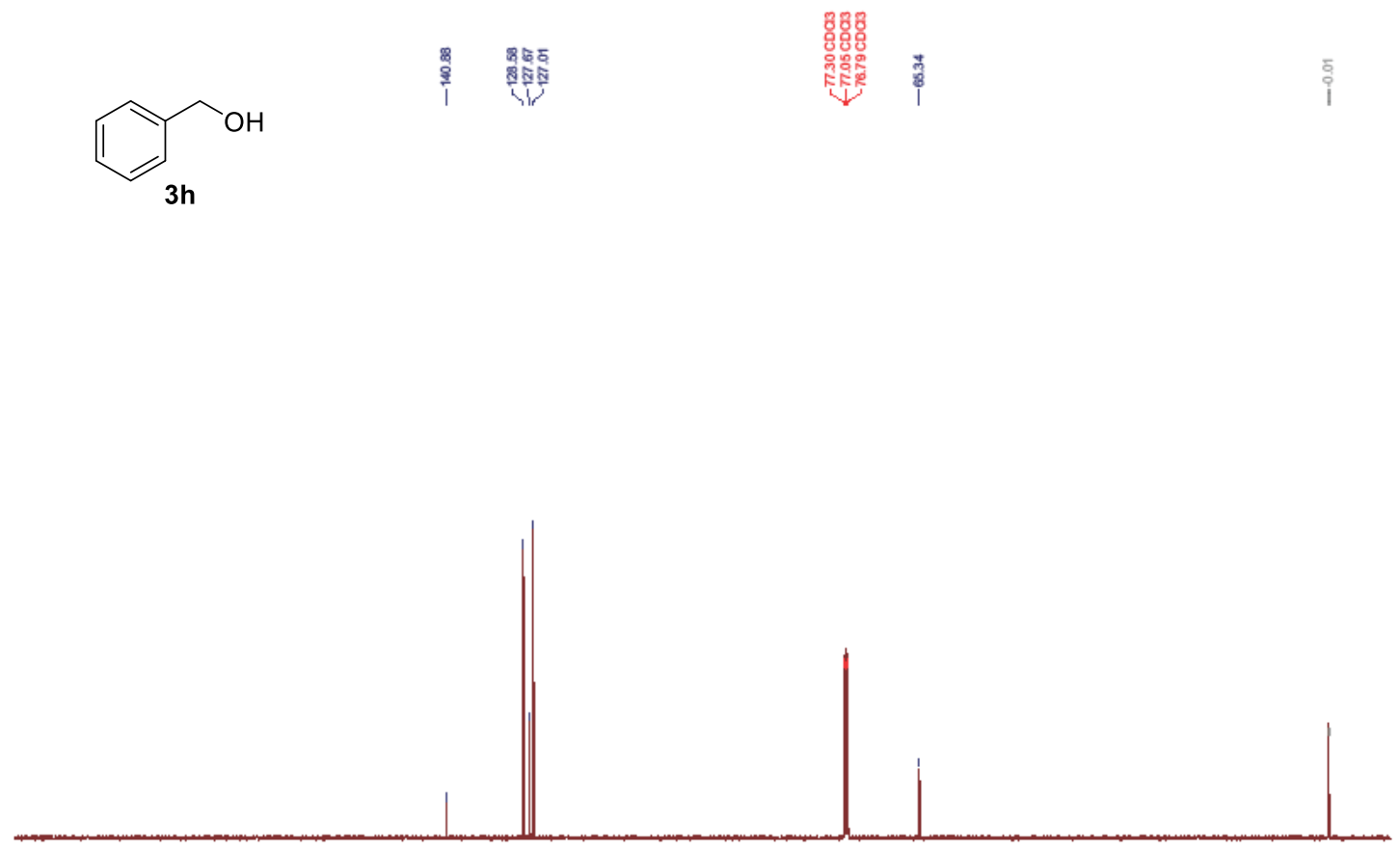
${ }^{1} \mathrm{H}$ NMR spectrum in $\mathrm{CDCl}_{3}(500 \mathrm{MHz})$
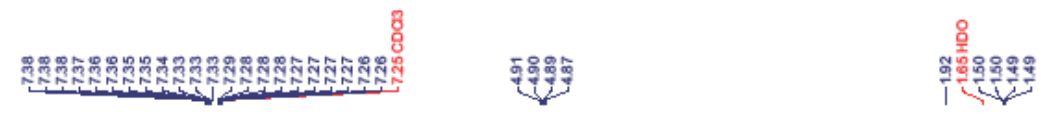<smiles>CC(O)c1ccccc1</smiles>

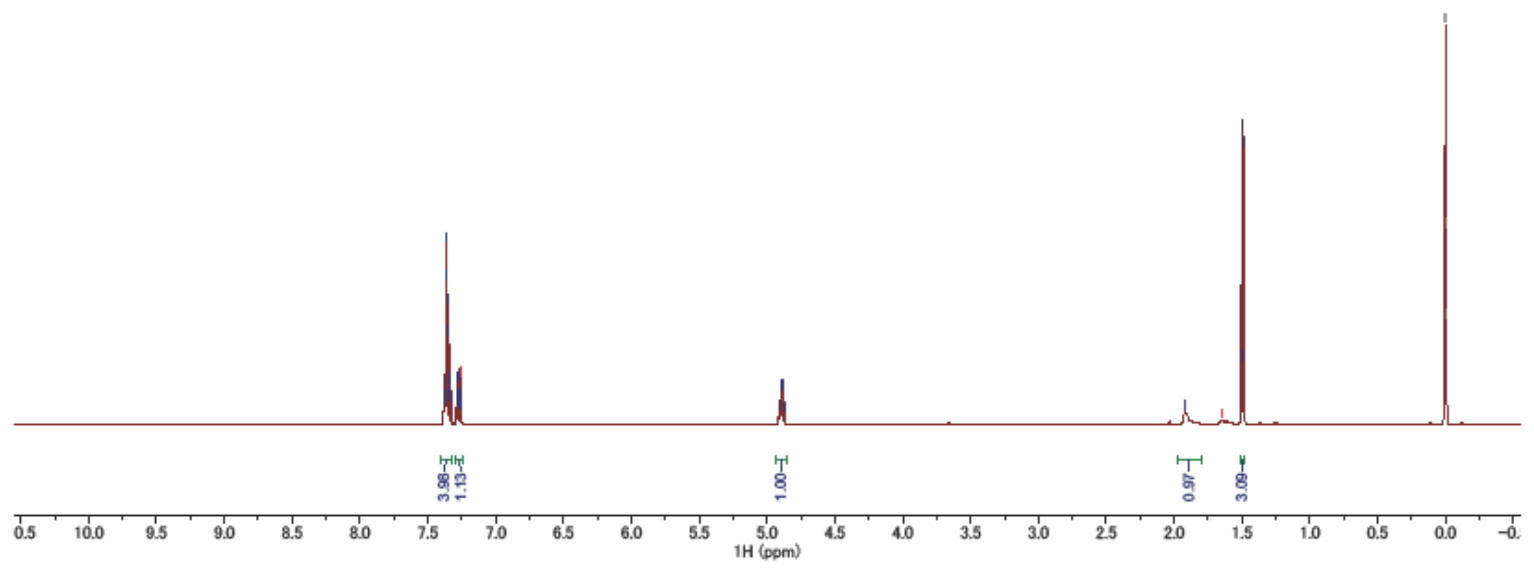

${ }^{13} \mathrm{C}$ NMR spectrum in $\mathrm{CDCl}_{3}(125 \mathrm{MHz})$<smiles>CC(O)c1ccccc1</smiles>

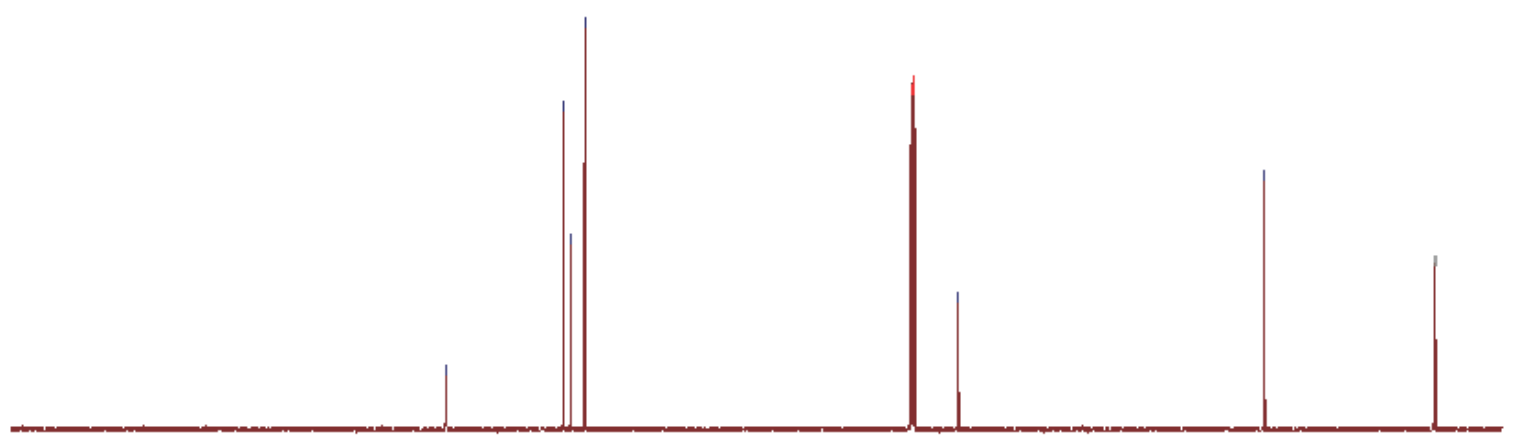

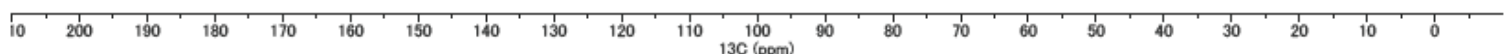


${ }^{1} \mathrm{H}$ NMR spectrum in $\mathrm{CDCl}_{3}(500 \mathrm{MHz})$

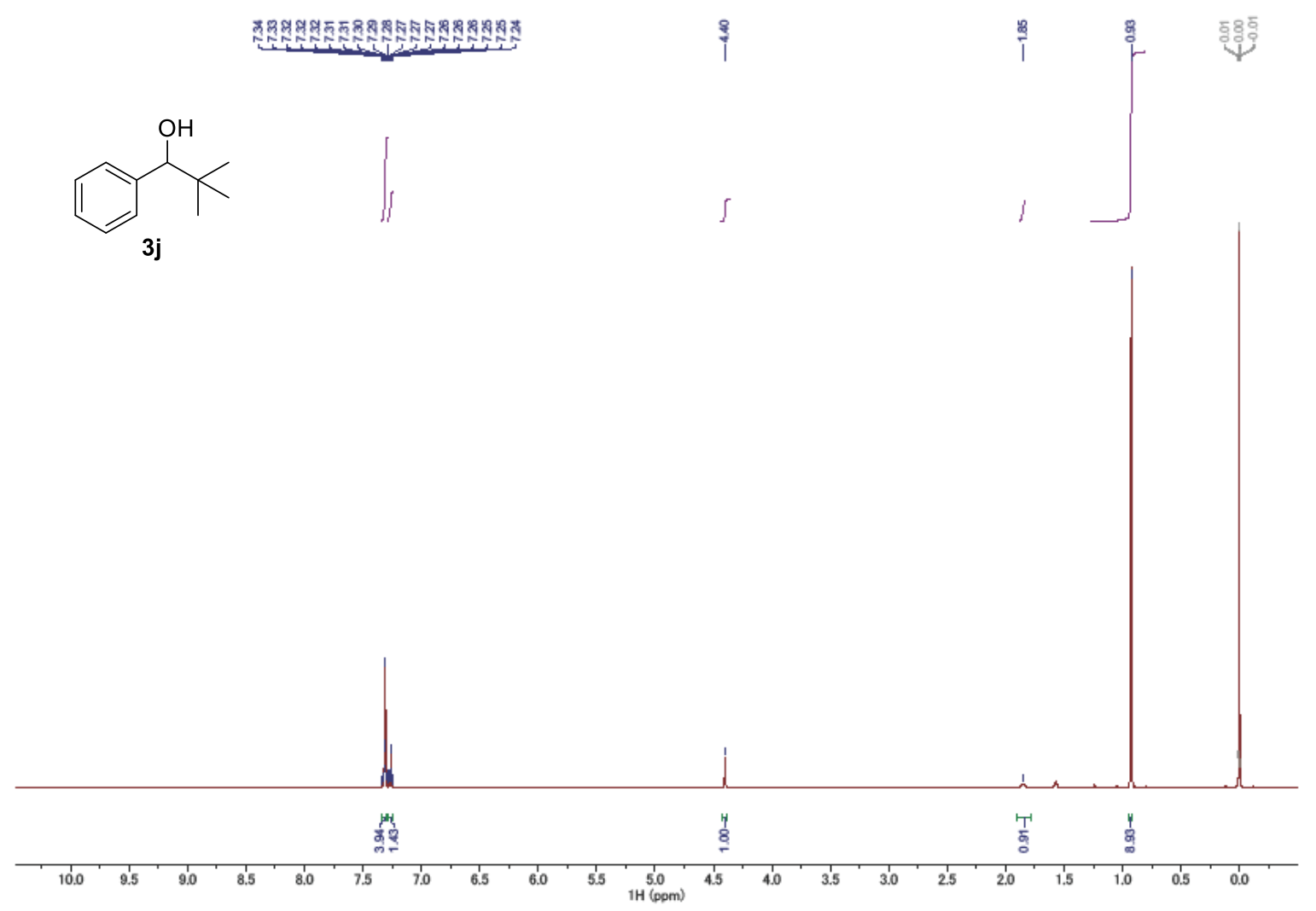

${ }^{13} \mathrm{C}$ NMR spectrum in $\mathrm{CDCl}_{3}(125 \mathrm{MHz})$<smiles>CC(C)(C)C(O)c1ccccc1</smiles> 
${ }^{1} \mathrm{H}$ NMR spectrum in $\mathrm{CDCl}_{3}(300 \mathrm{MHz})$
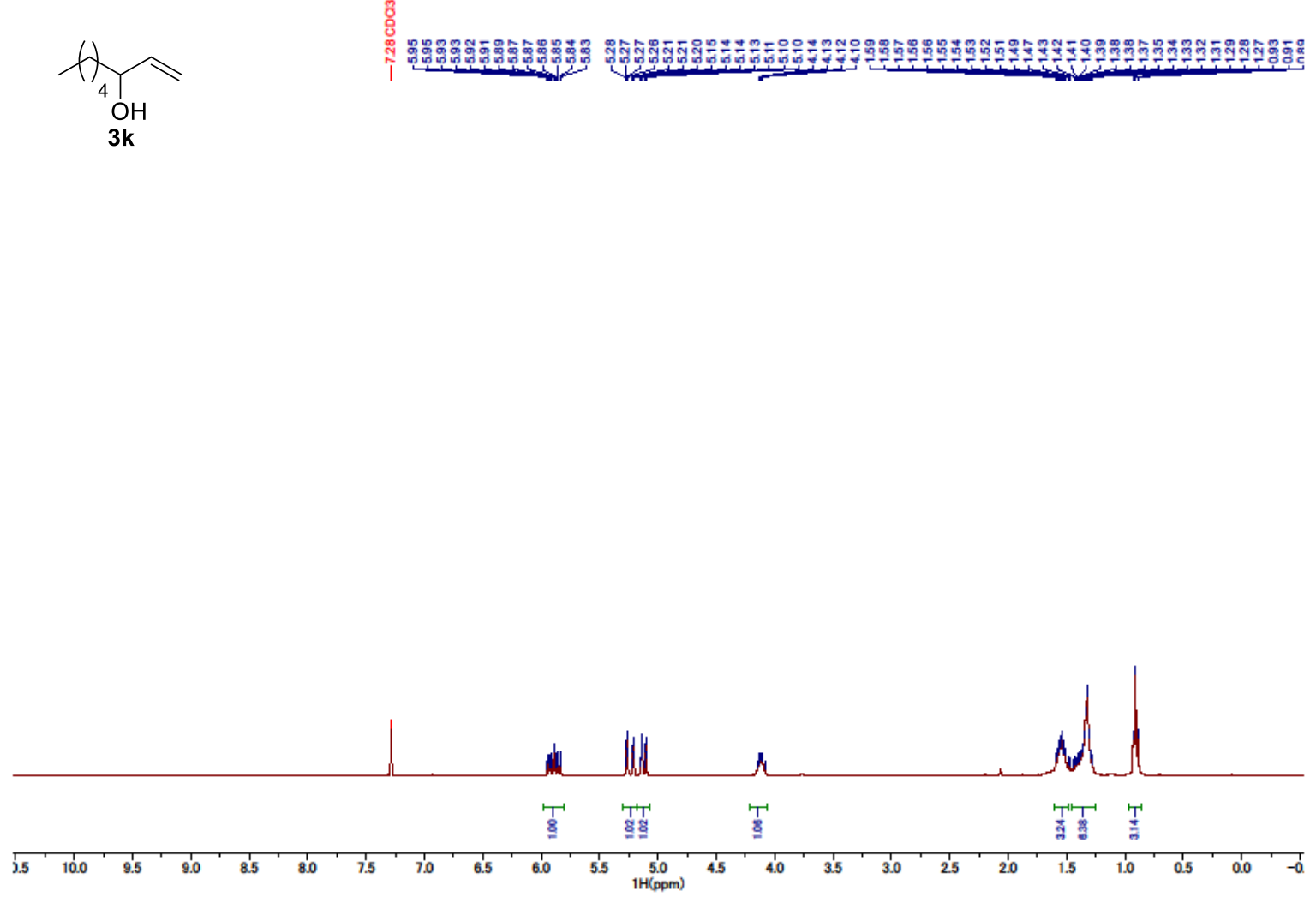

${ }^{13} \mathrm{C}$ NMR spectrum in $\mathrm{CDCl}_{3}(75 \mathrm{MHz})$
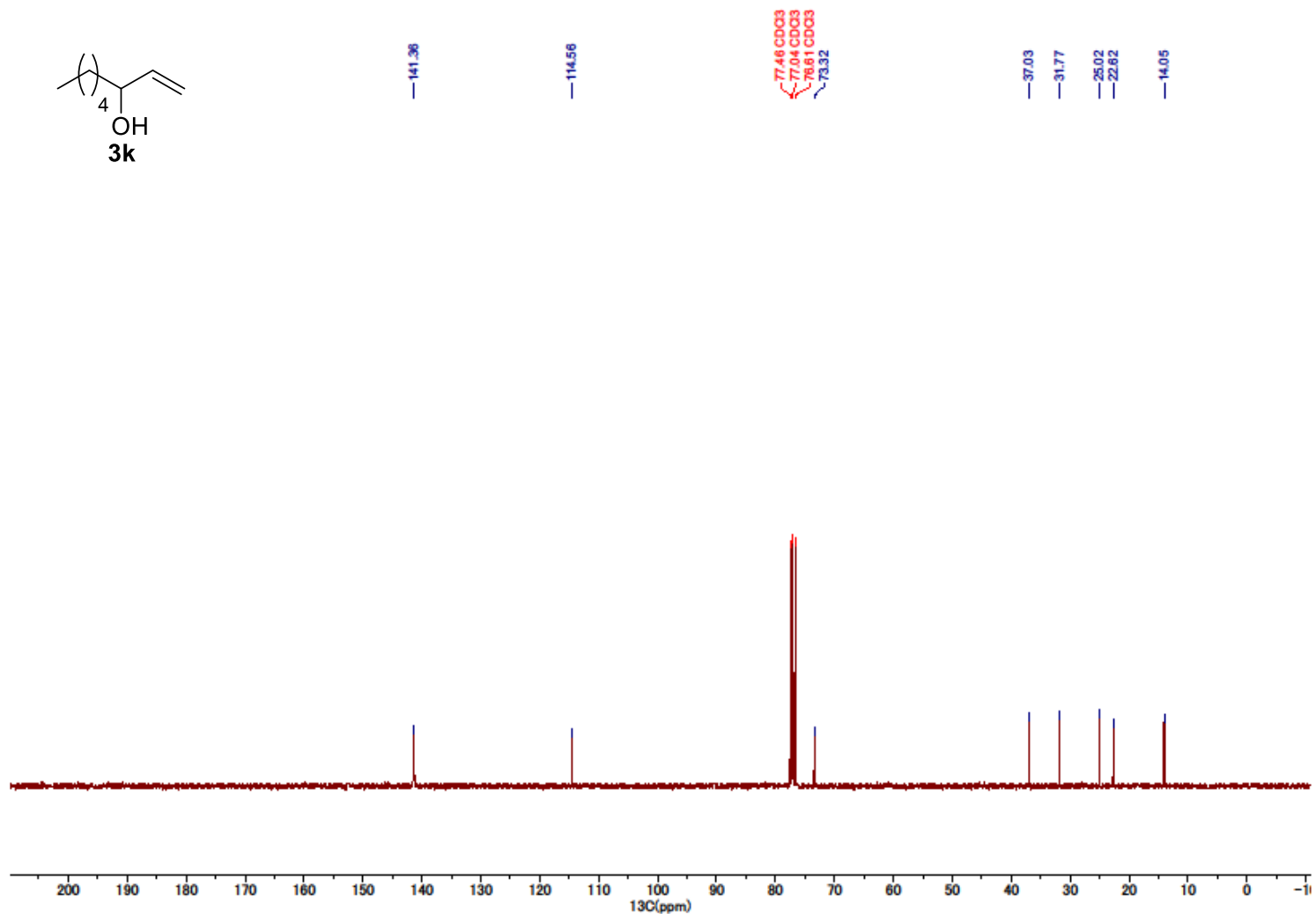
${ }^{1} \mathrm{H}$ NMR spectrum in $\mathrm{CDCl}_{3}(500 \mathrm{MHz})$

:

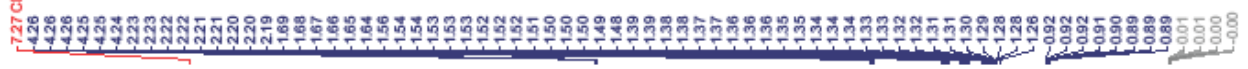<smiles>C#CCO</smiles>

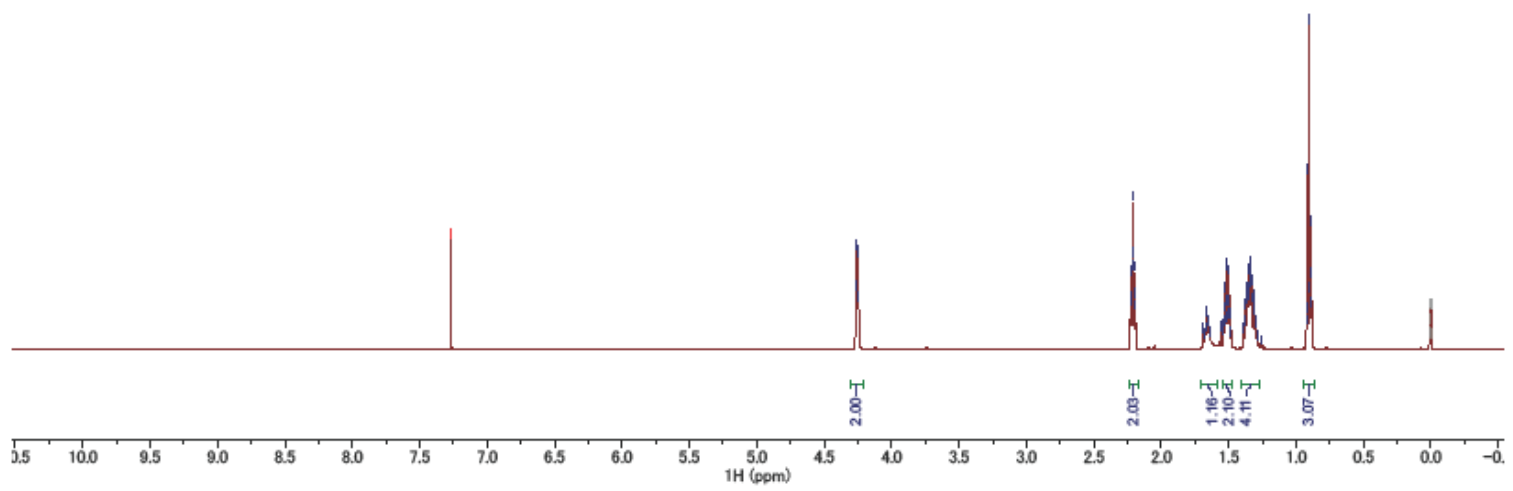

${ }^{13} \mathrm{C}$ NMR spectrum in $\mathrm{CDCl}_{3}(125 \mathrm{MHz})$
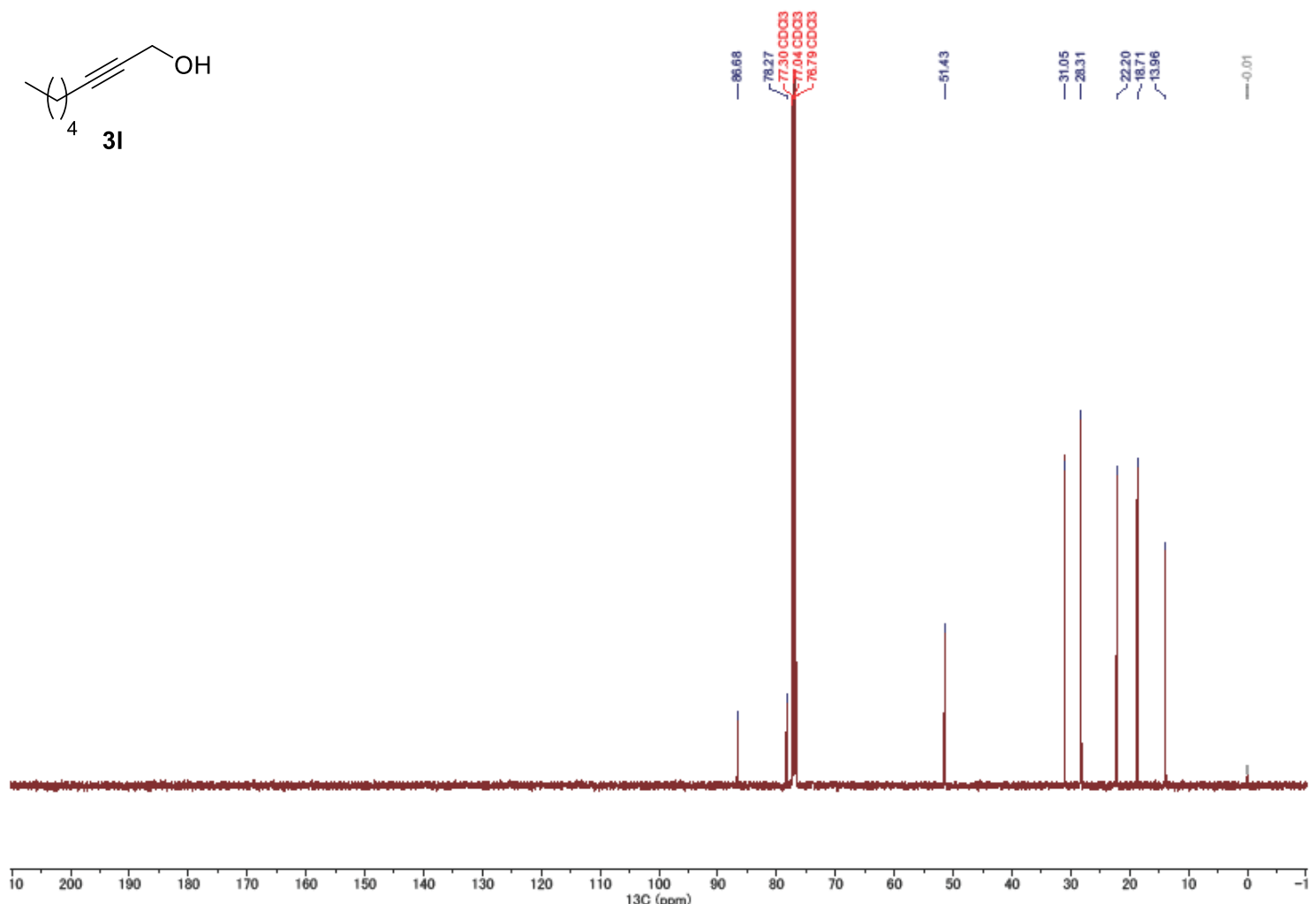
${ }^{1} \mathrm{H}$ NMR spectrum in $\mathrm{CDCl}_{3}(300 \mathrm{MHz})$
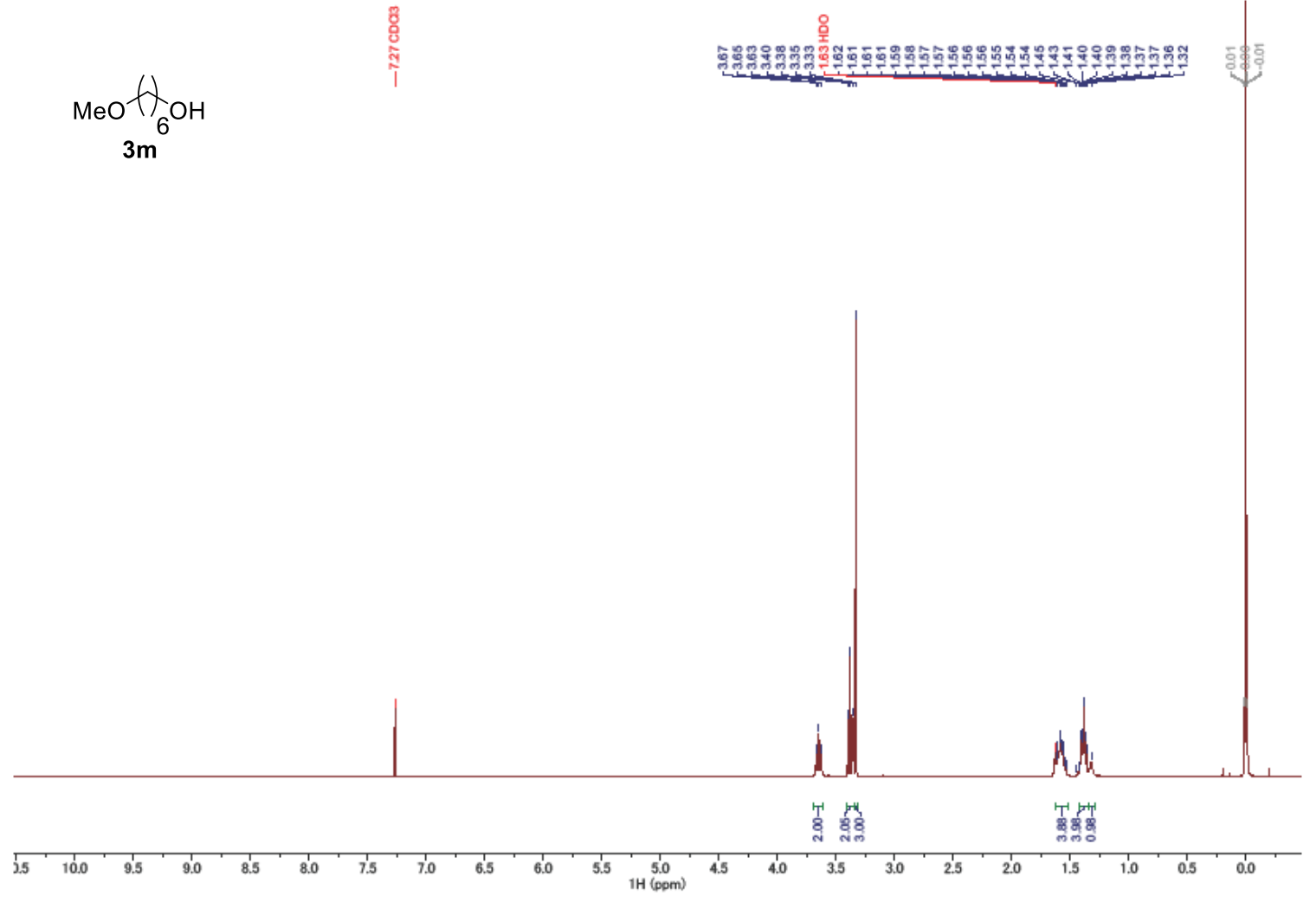

${ }^{13} \mathrm{C}$ NMR spectrum in $\mathrm{CDCl}_{3}(75 \mathrm{MHz})$
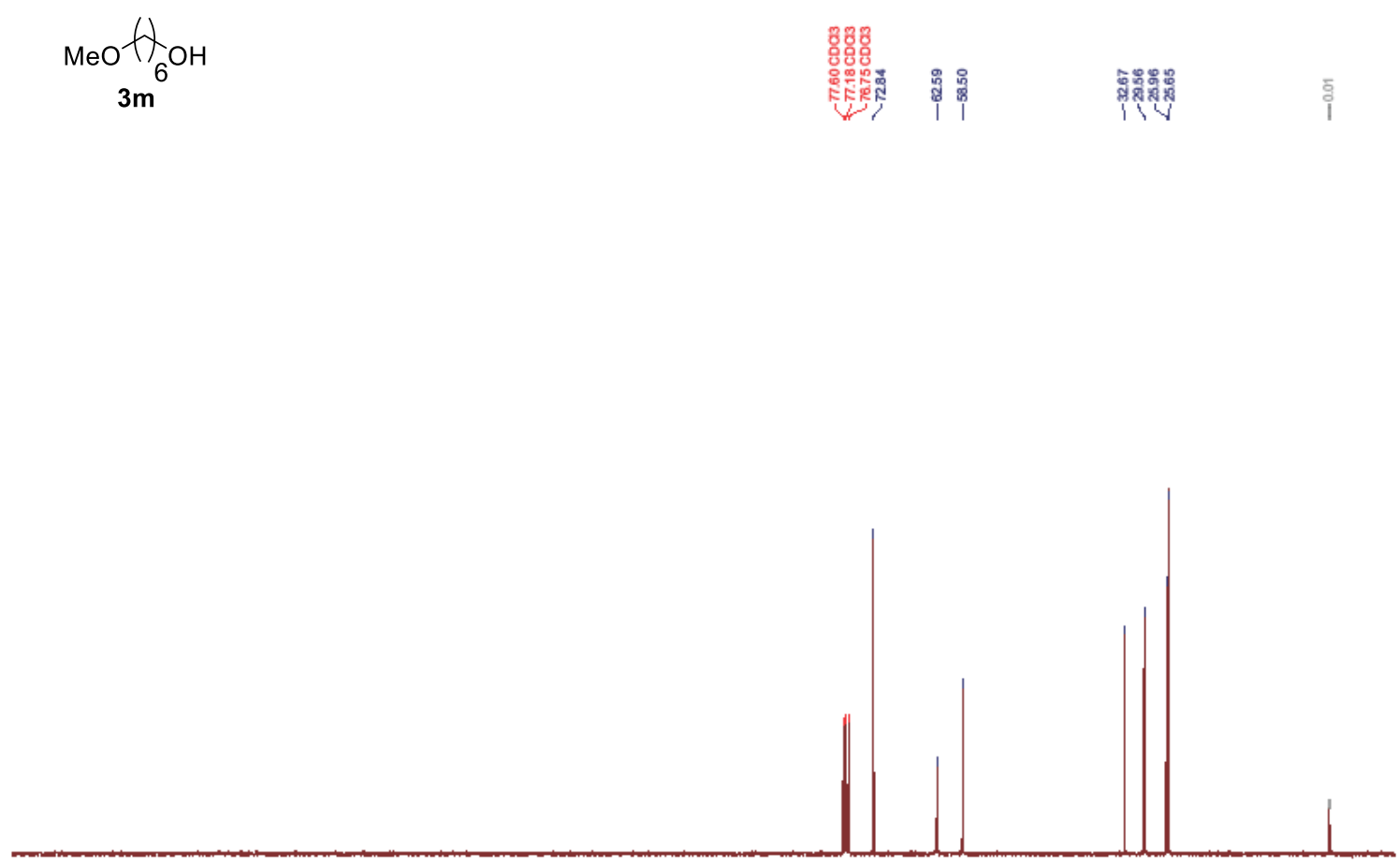

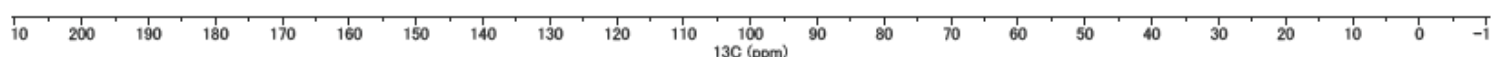


${ }^{1} \mathrm{H}$ NMR spectrum in $\mathrm{CDCl}_{3}(500 \mathrm{MHz})$

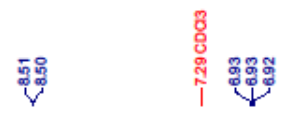

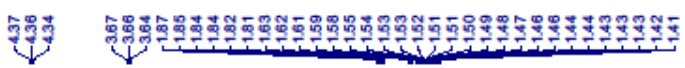<smiles>OC1CCC(Oc2ncccn2)C1</smiles>

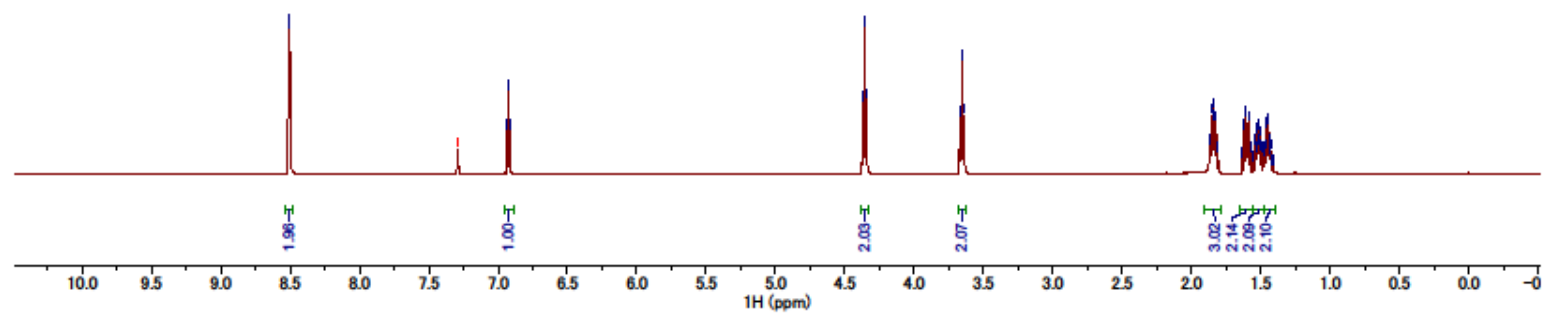

${ }^{13} \mathrm{C}$ NMR spectrum in $\mathrm{CDCl}_{3}(125 \mathrm{MHz})$

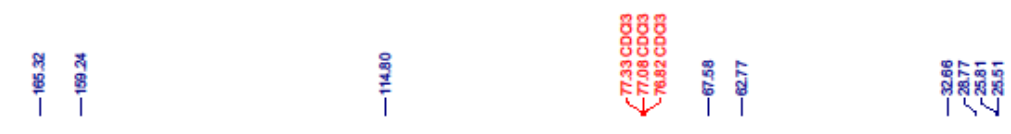<smiles>CC(O)Oc1ncccn1</smiles>

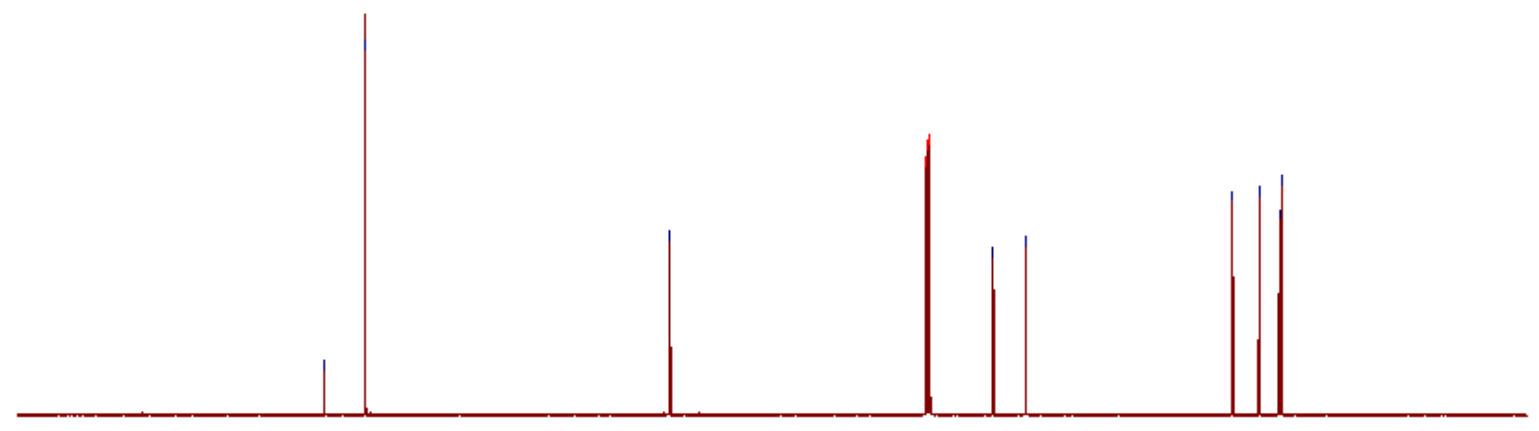

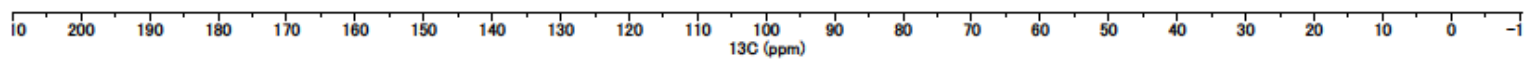


${ }^{1} \mathrm{H}$ NMR spectrum in $\mathrm{CDCl}_{3}(500 \mathrm{MHz})$
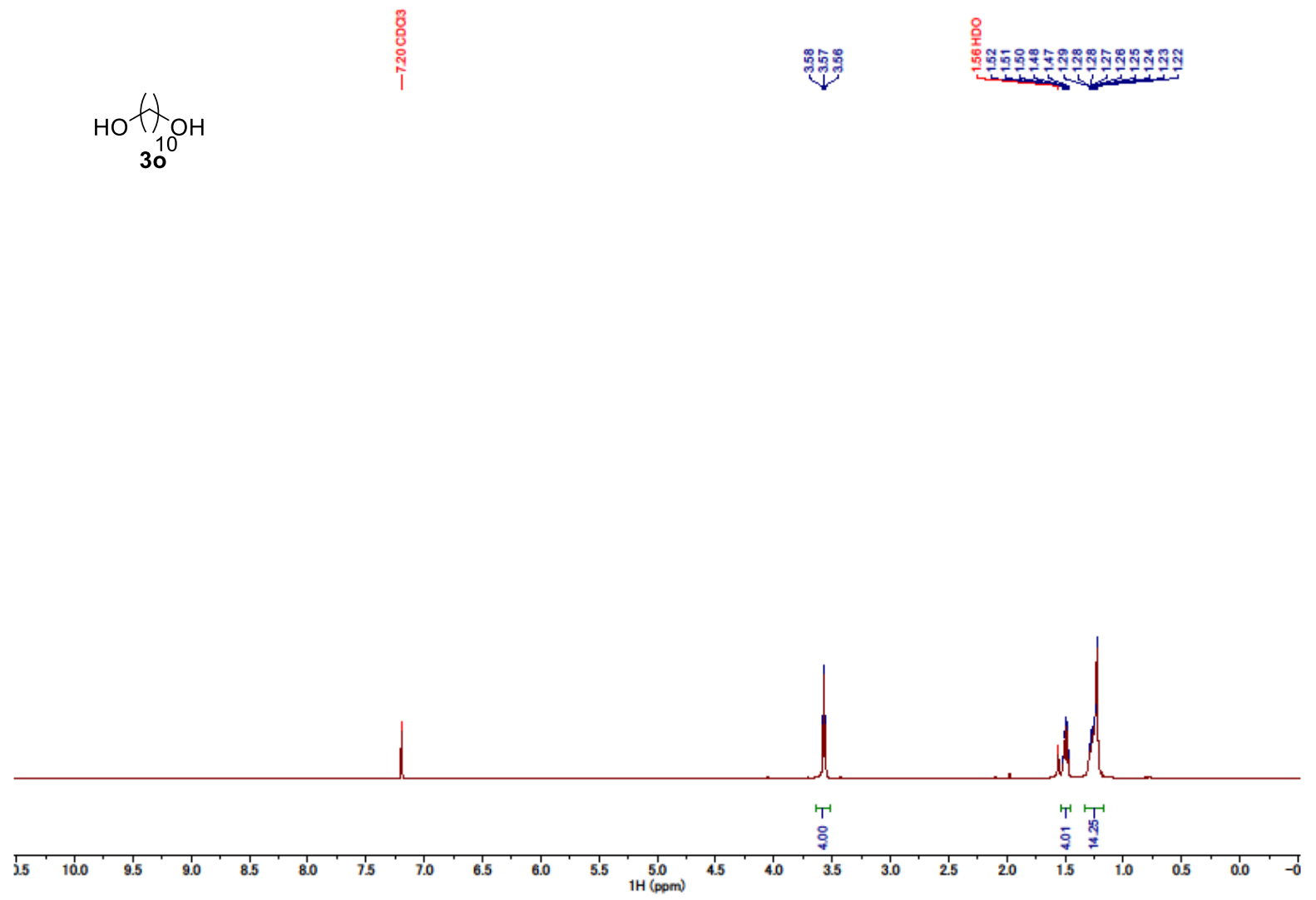

${ }^{13} \mathrm{C}$ NMR spectrum in $\mathrm{CDCl}_{3}(125 \mathrm{MHz})$

$$
\underset{30}{\mathrm{HO}}+\underset{10 \mathrm{OH}}{30}
$$
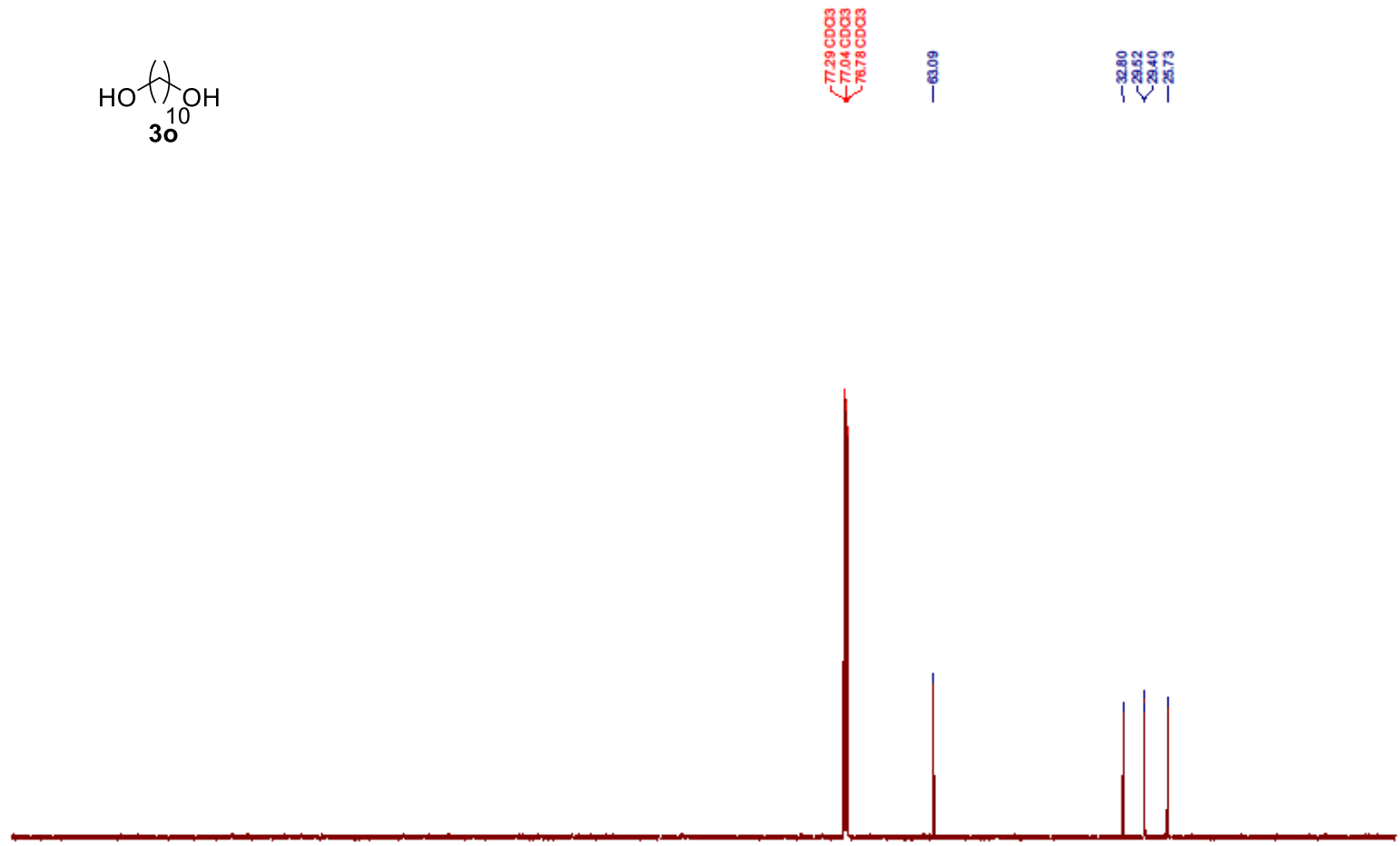

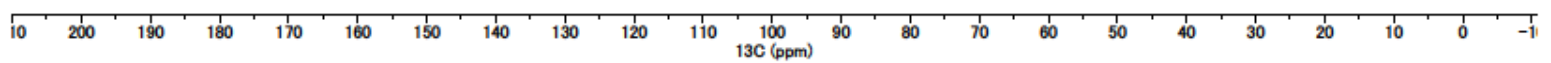


${ }^{1} \mathrm{H}$ NMR spectrum in $\mathrm{CDCl}_{3}(500 \mathrm{MHz})$
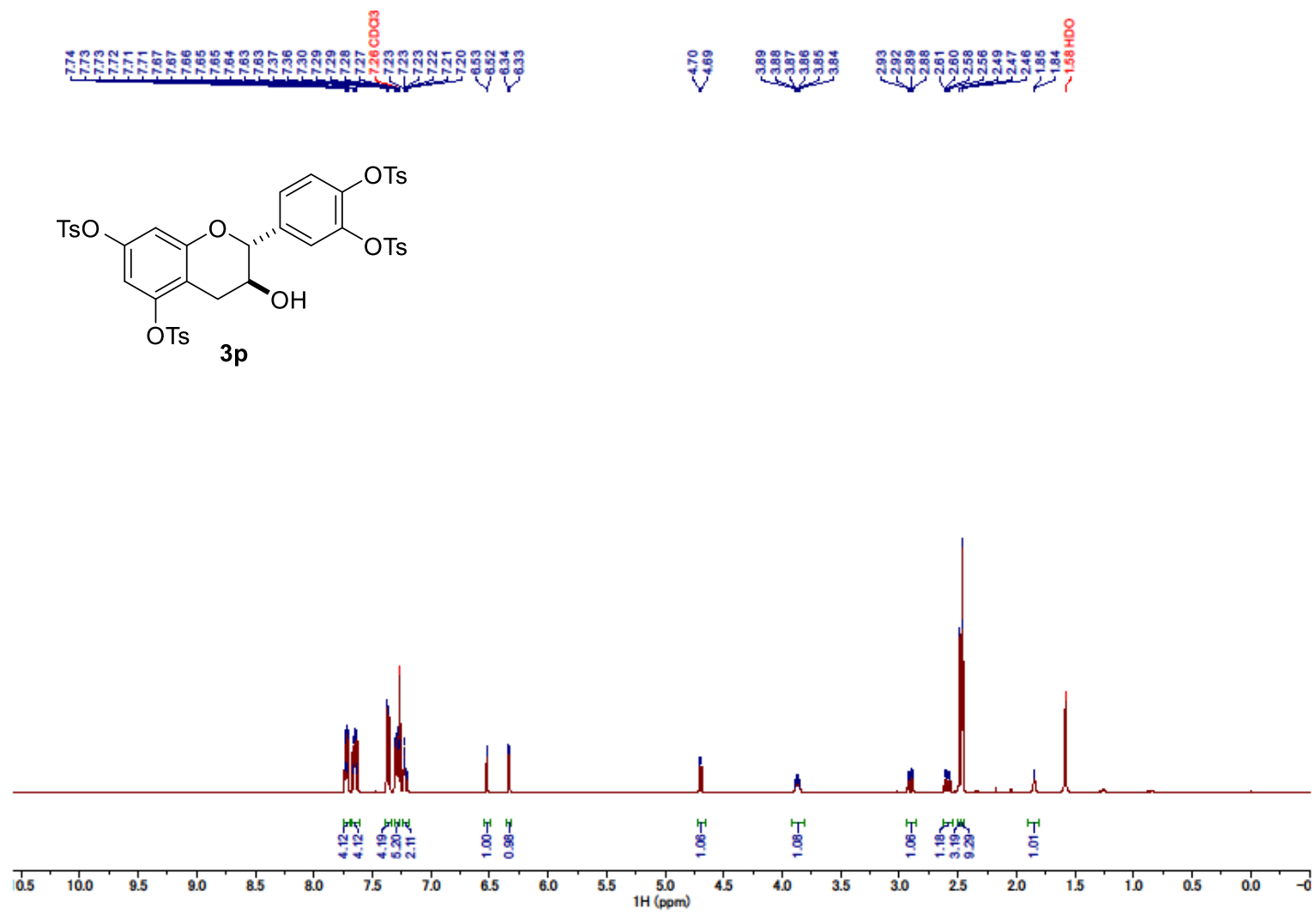

${ }^{13} \mathrm{C}$ NMR spectrum in $\mathrm{CDCl}_{3}(125 \mathrm{MHz})$
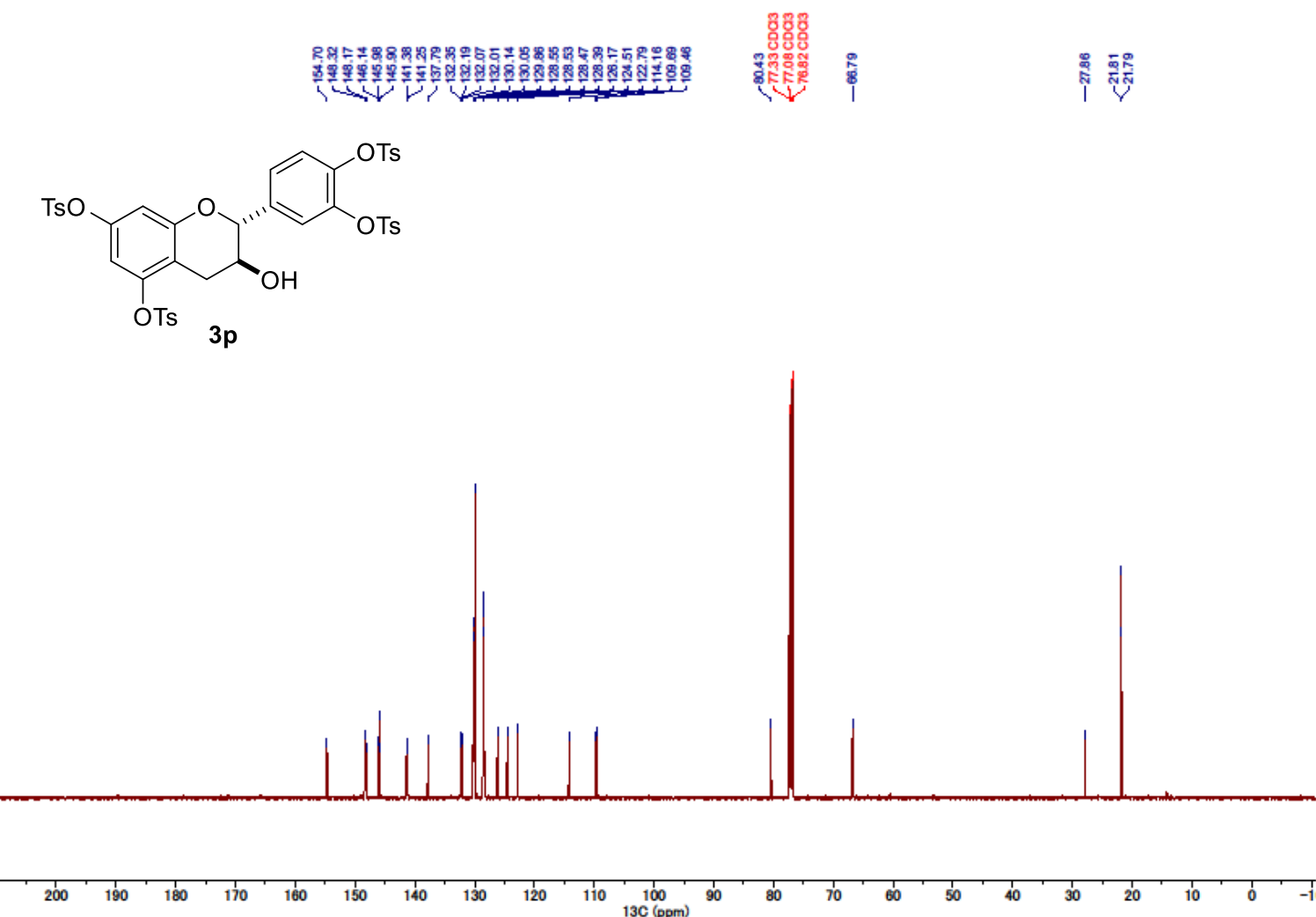
${ }^{1} \mathrm{H}$ NMR spectrum in $\mathrm{CDCl}_{3}(300 \mathrm{MHz})$
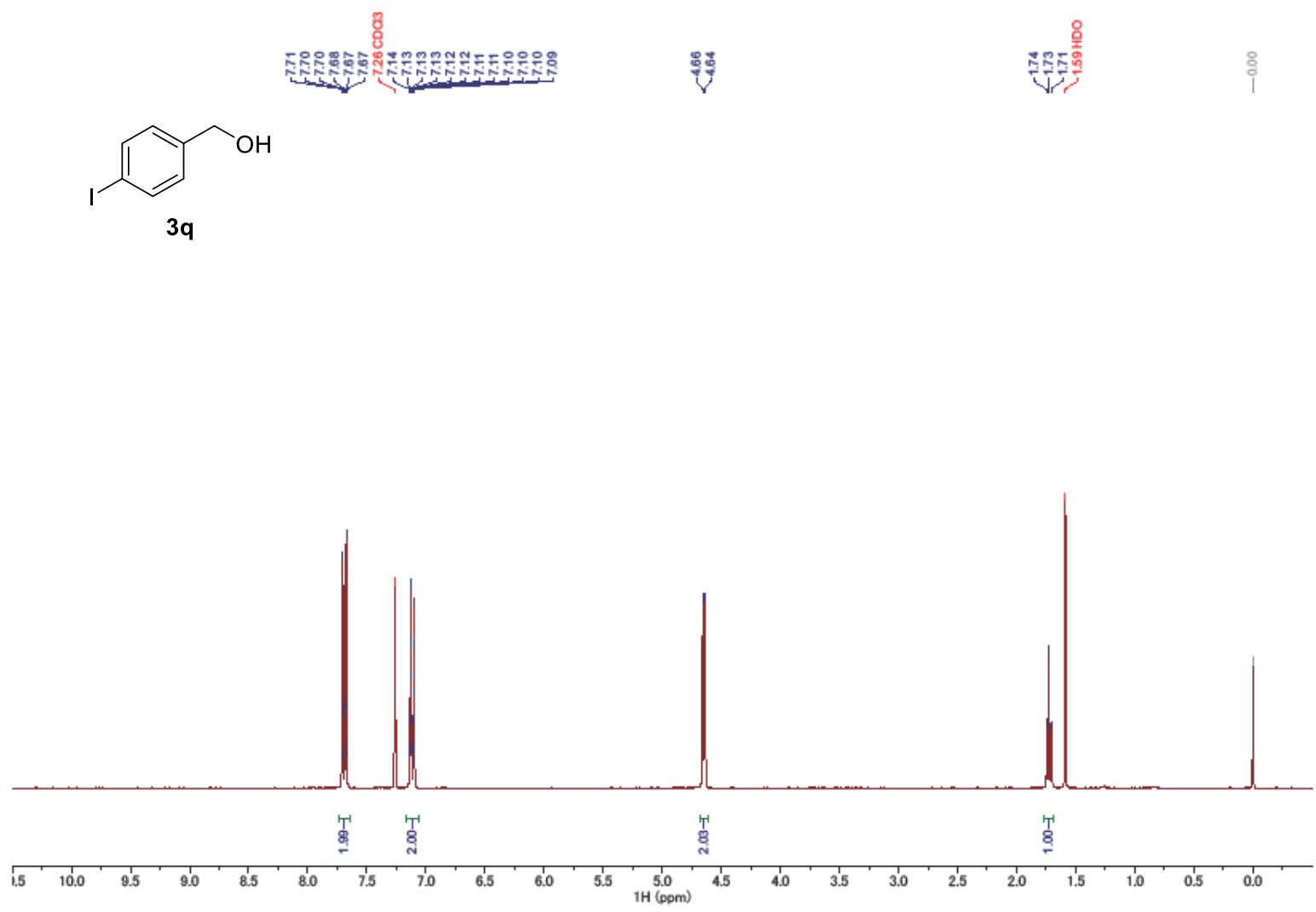

${ }^{13} \mathrm{C}$ NMR spectrum in $\mathrm{CDCl}_{3}(125 \mathrm{MHz})$<smiles>OCc1ccc(I)cc1</smiles>

$3 q$

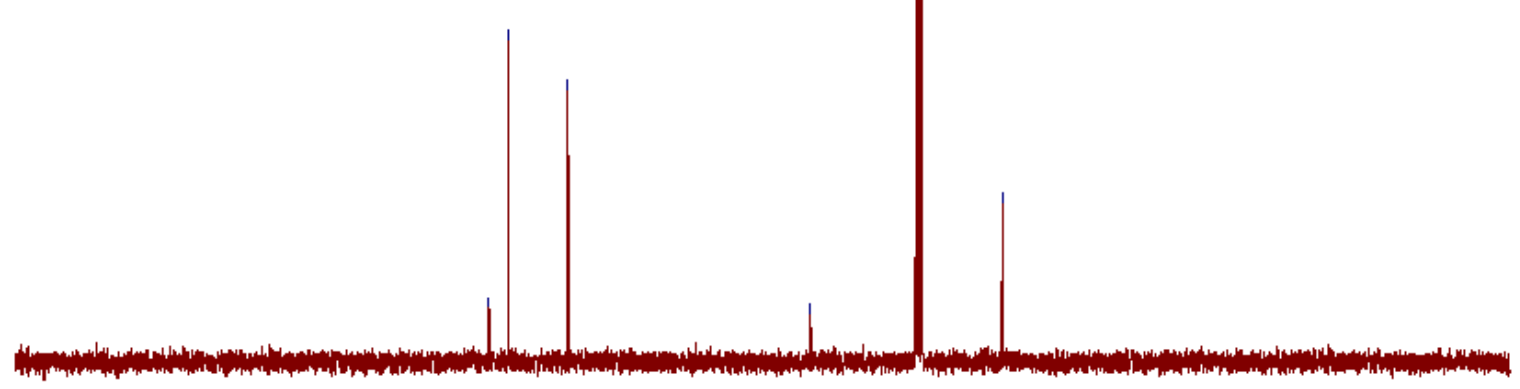

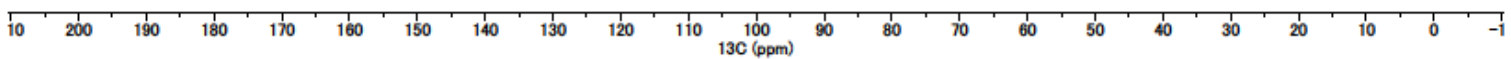


${ }^{1} \mathrm{H}$ NMR spectrum in $\mathrm{CDCl}_{3}(500 \mathrm{MHz})$<smiles>C=CC(O)=[Te]</smiles>

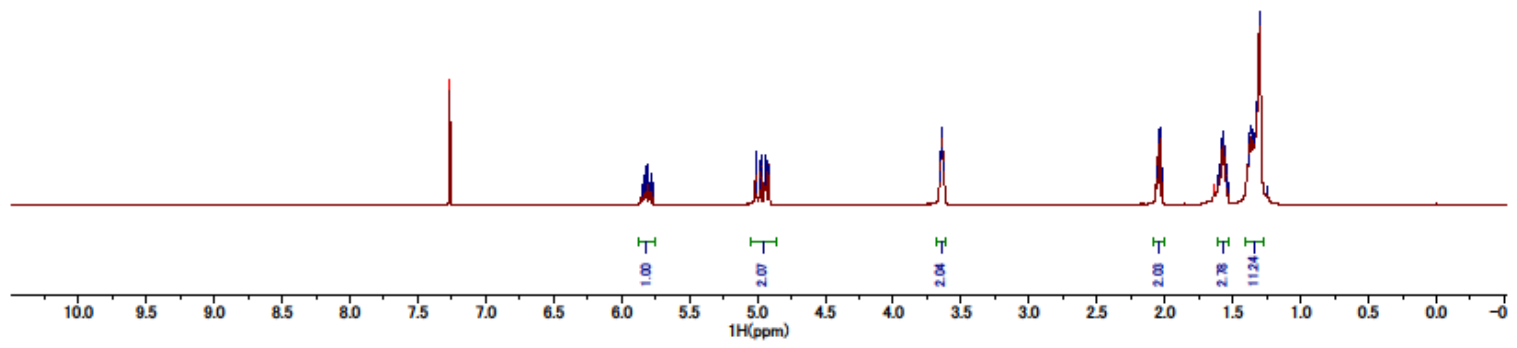

${ }^{13} \mathrm{C}$ NMR spectrum in $\mathrm{CDCl}_{3}(125 \mathrm{MHz})$<smiles>C=CC(=O)O</smiles> 
${ }^{1} \mathrm{H}$ NMR spectrum in $\mathrm{CDCl}_{3}(300 \mathrm{MHz})$

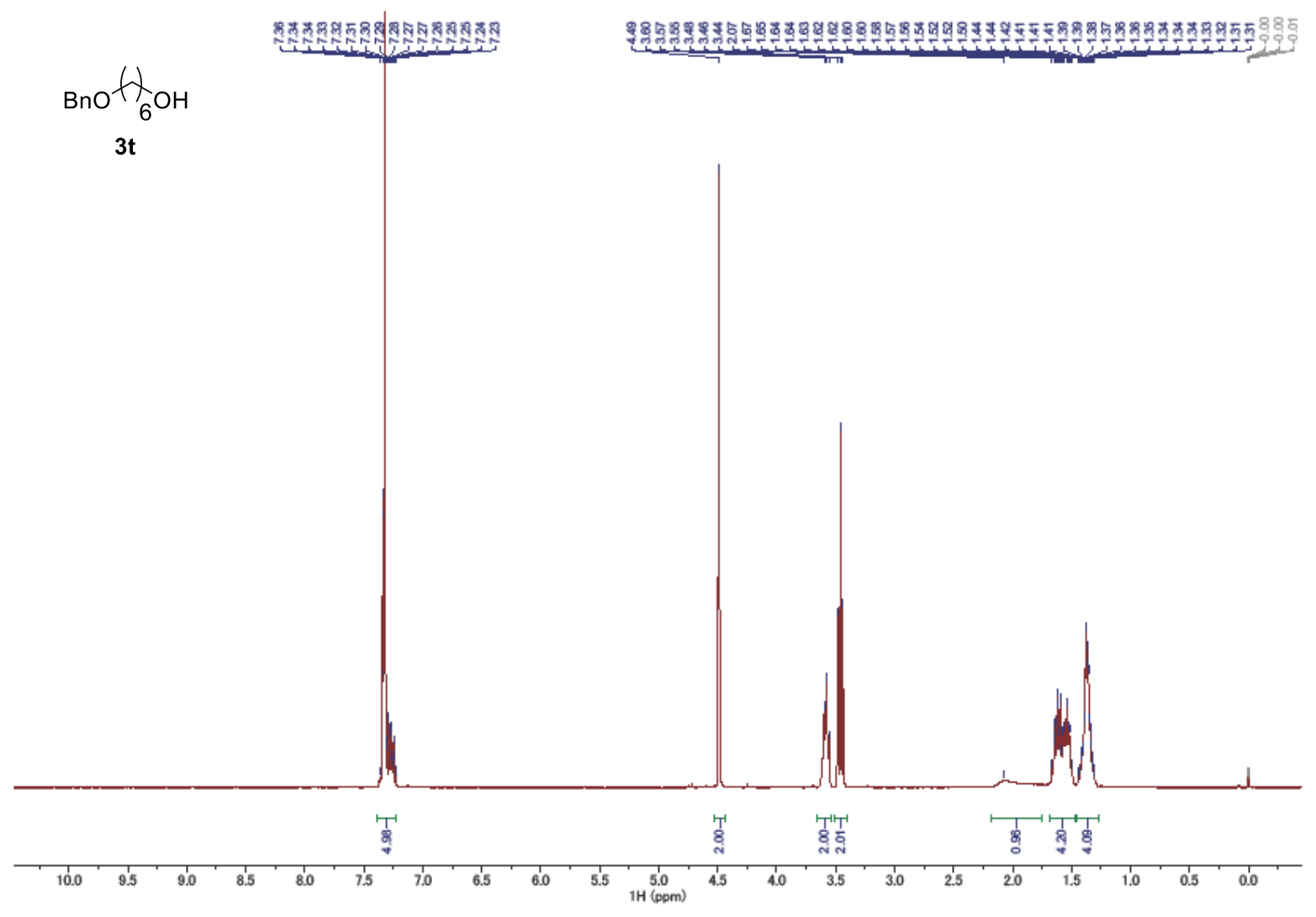

${ }^{13} \mathrm{C}$ NMR spectrum in $\mathrm{CDCl}_{3}(75 \mathrm{MHz})$

$$
\mathrm{BnO}_{3 \mathrm{t}}+\mathrm{X}_{6} \mathrm{OH}
$$
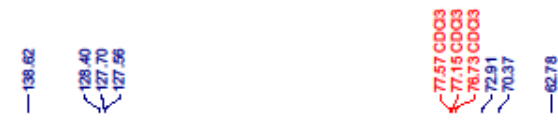

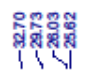

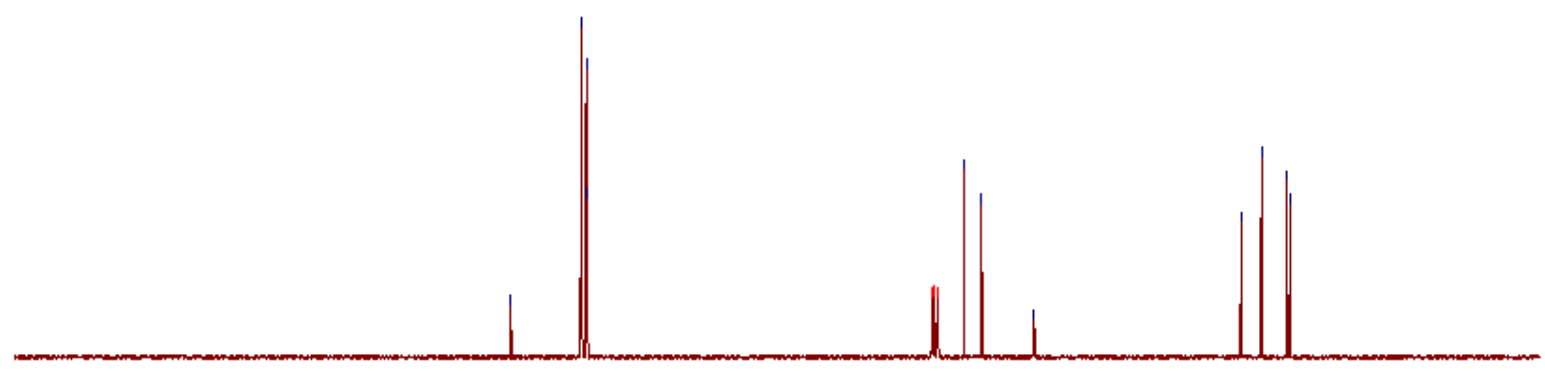

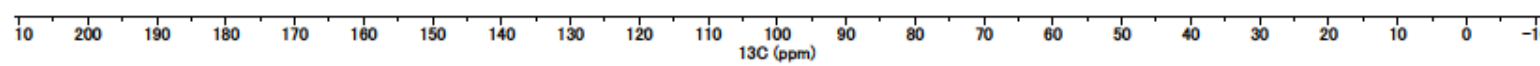


${ }^{1} \mathrm{H}$ NMR spectrum in $\mathrm{CDCl}_{3}(500 \mathrm{MHz})$

$$
\underset{6}{\mathrm{PMBO}} \underset{6}{\mathrm{SI-7}}
$$

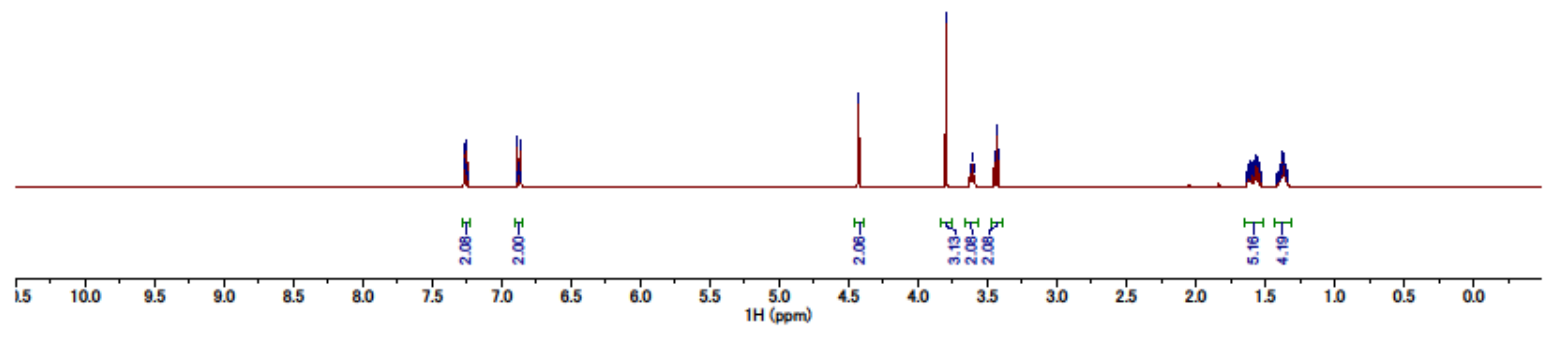

${ }^{13} \mathrm{C}$ NMR spectrum in $\mathrm{CDCl}_{3}(75 \mathrm{MHz})$

PMBO ${ }_{6} \mathrm{OH}$

SI-7

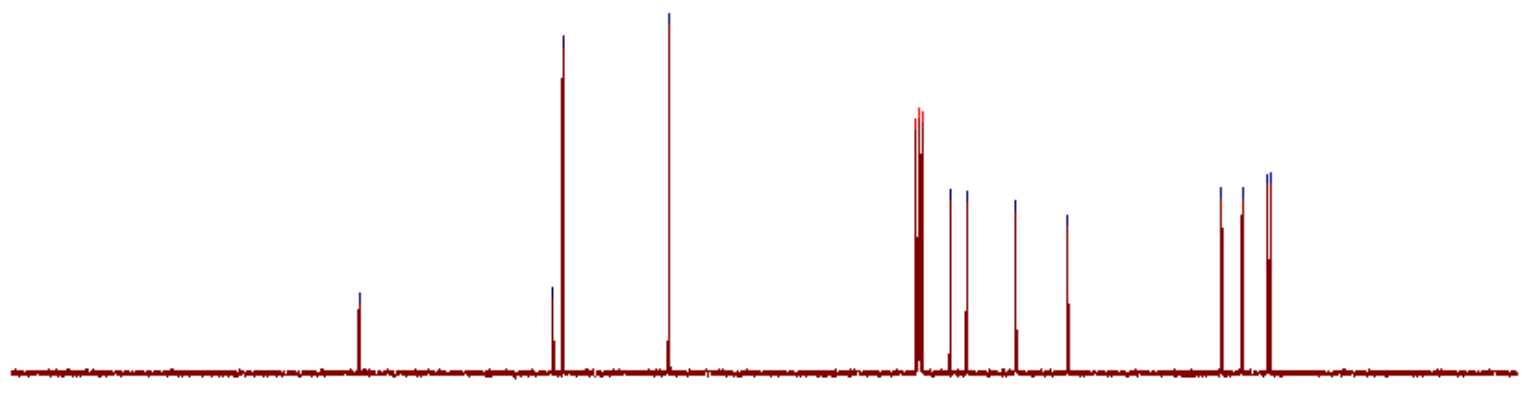

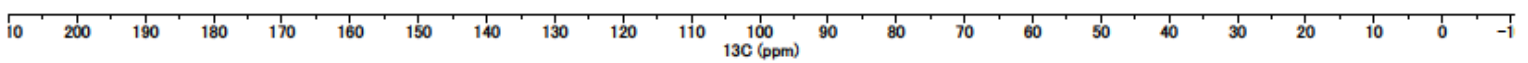


${ }^{1} \mathrm{H}$ NMR spectrum in $\mathrm{CDCl}_{3}(500 \mathrm{MHz})$
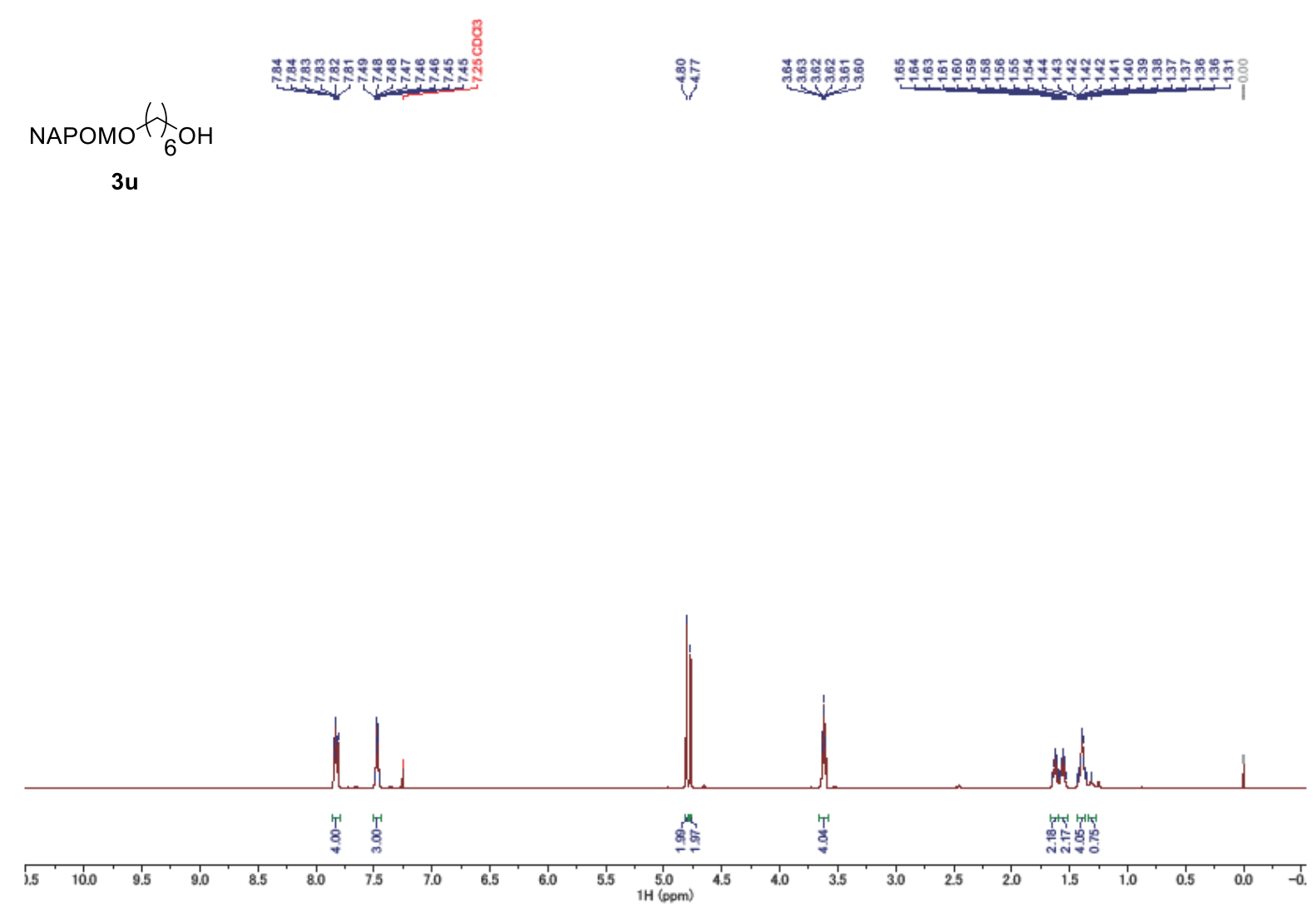

${ }^{13} \mathrm{C}$ NMR spectrum in $\mathrm{CDCl}_{3}(125 \mathrm{MHz})$

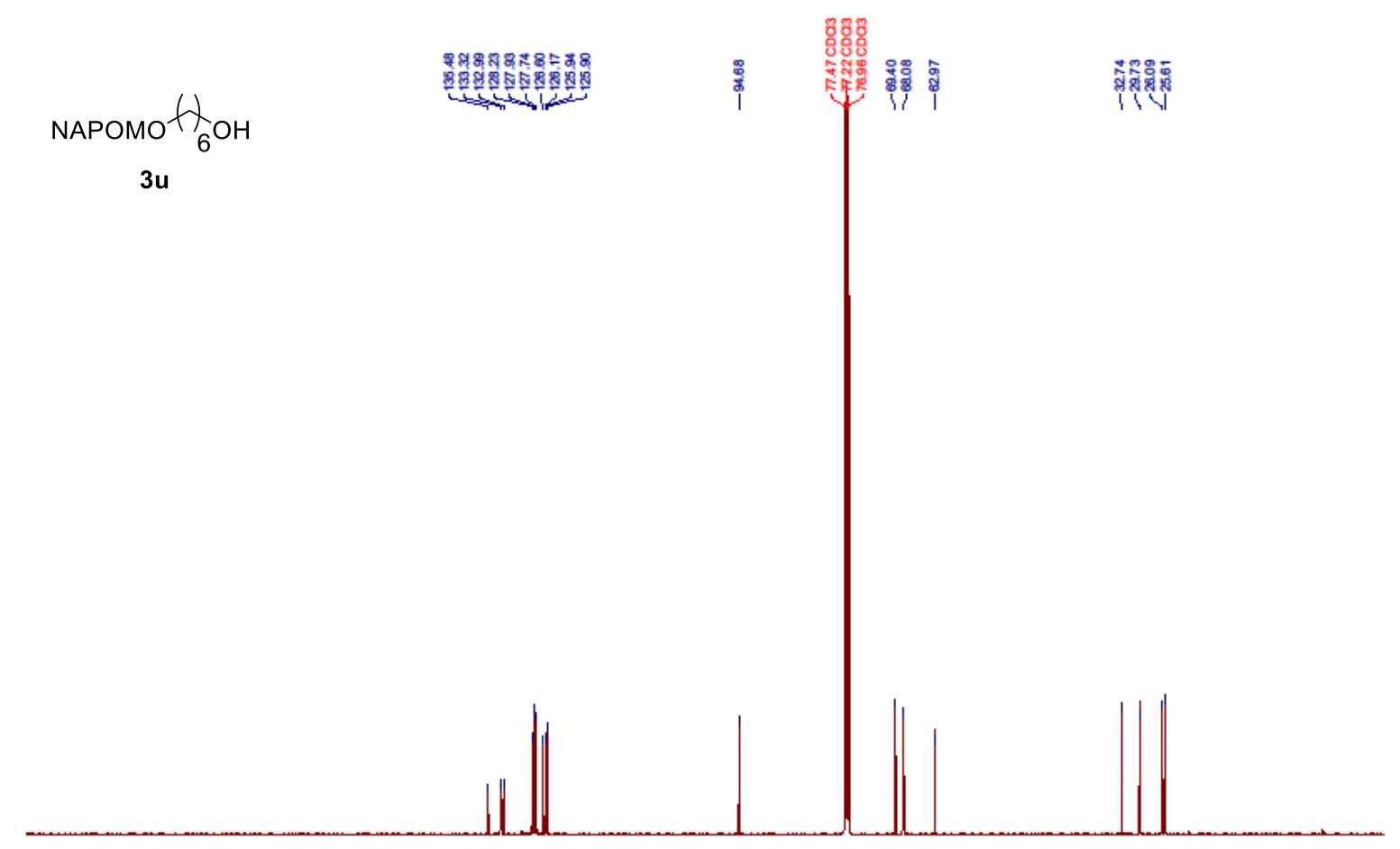

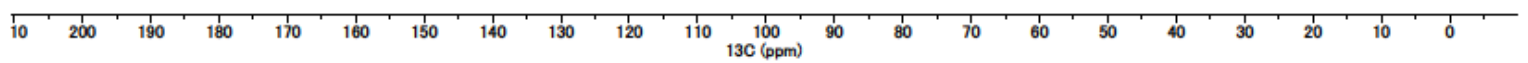


${ }^{1} \mathrm{H}$ NMR spectrum in $\mathrm{CDCl}_{3}(300 \mathrm{MHz})$

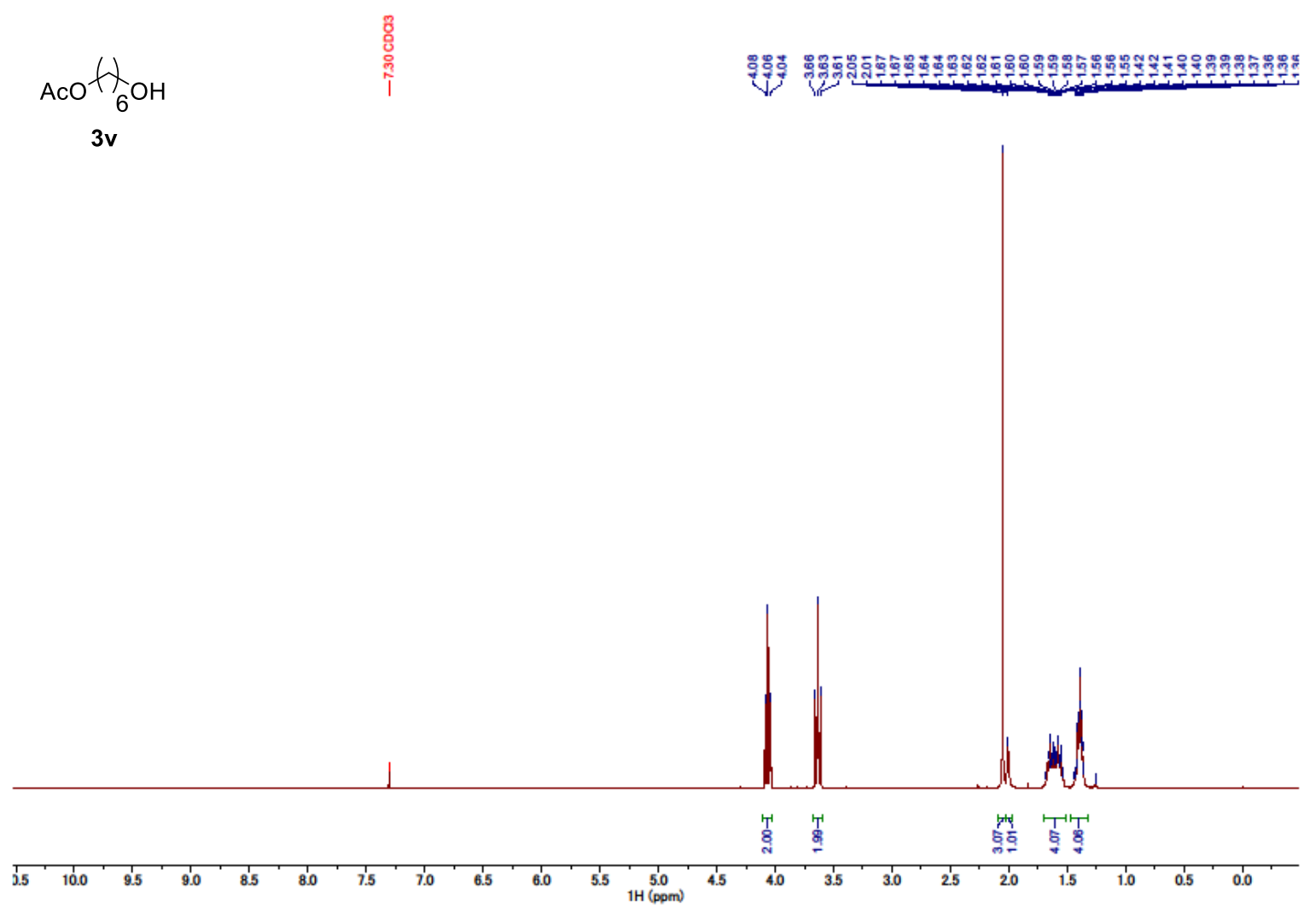

${ }^{13} \mathrm{C}$ NMR spectrum in $\mathrm{CDCl}_{3}(75 \mathrm{MHz})$
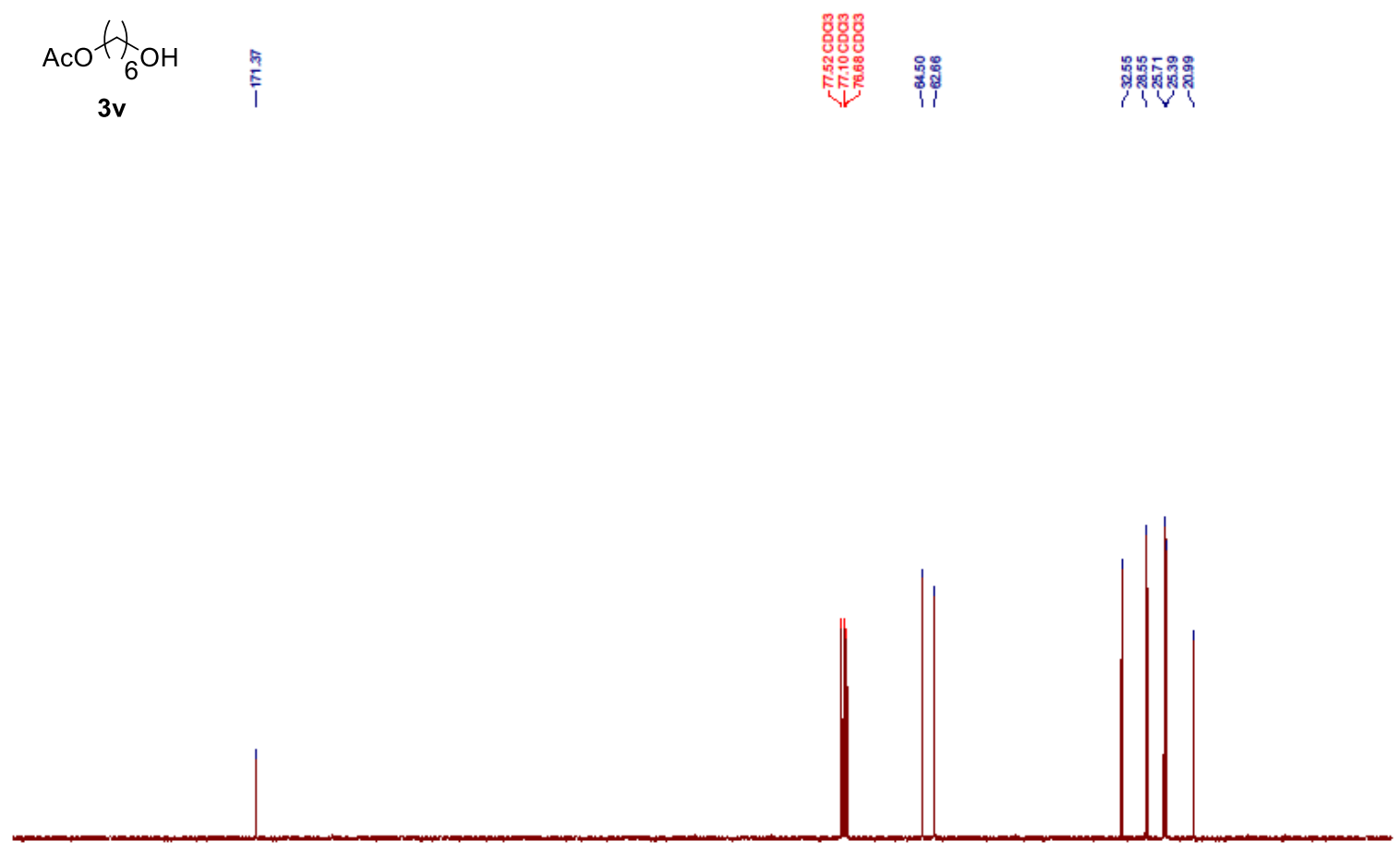

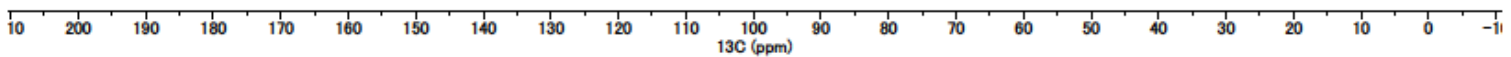


${ }^{1} \mathrm{H}$ NMR spectrum in $\mathrm{CDCl}_{3}(300 \mathrm{MHz})$

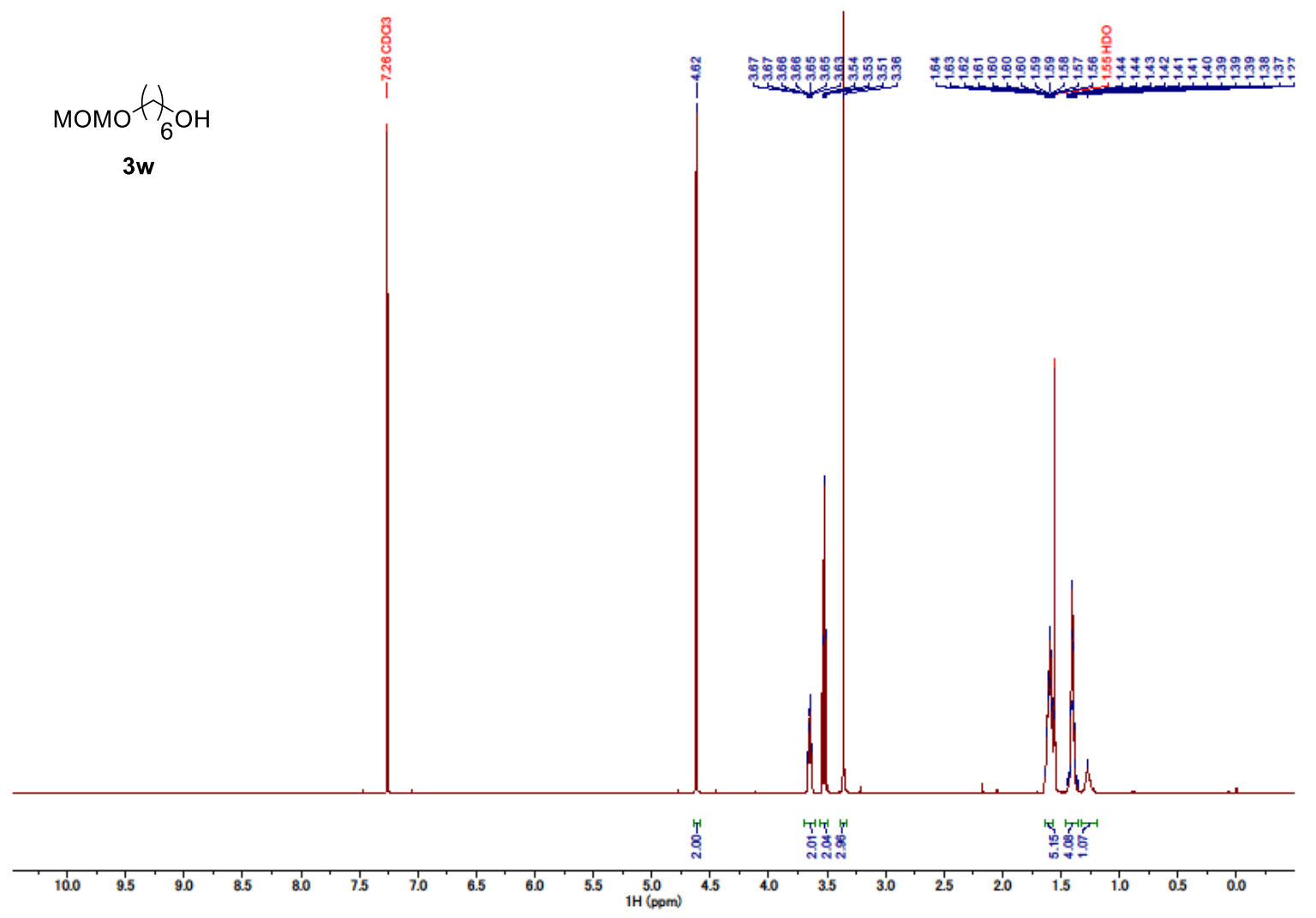

${ }^{13} \mathrm{C}$ NMR spectrum in $\mathrm{CDCl}_{3}(75 \mathrm{MHz})$
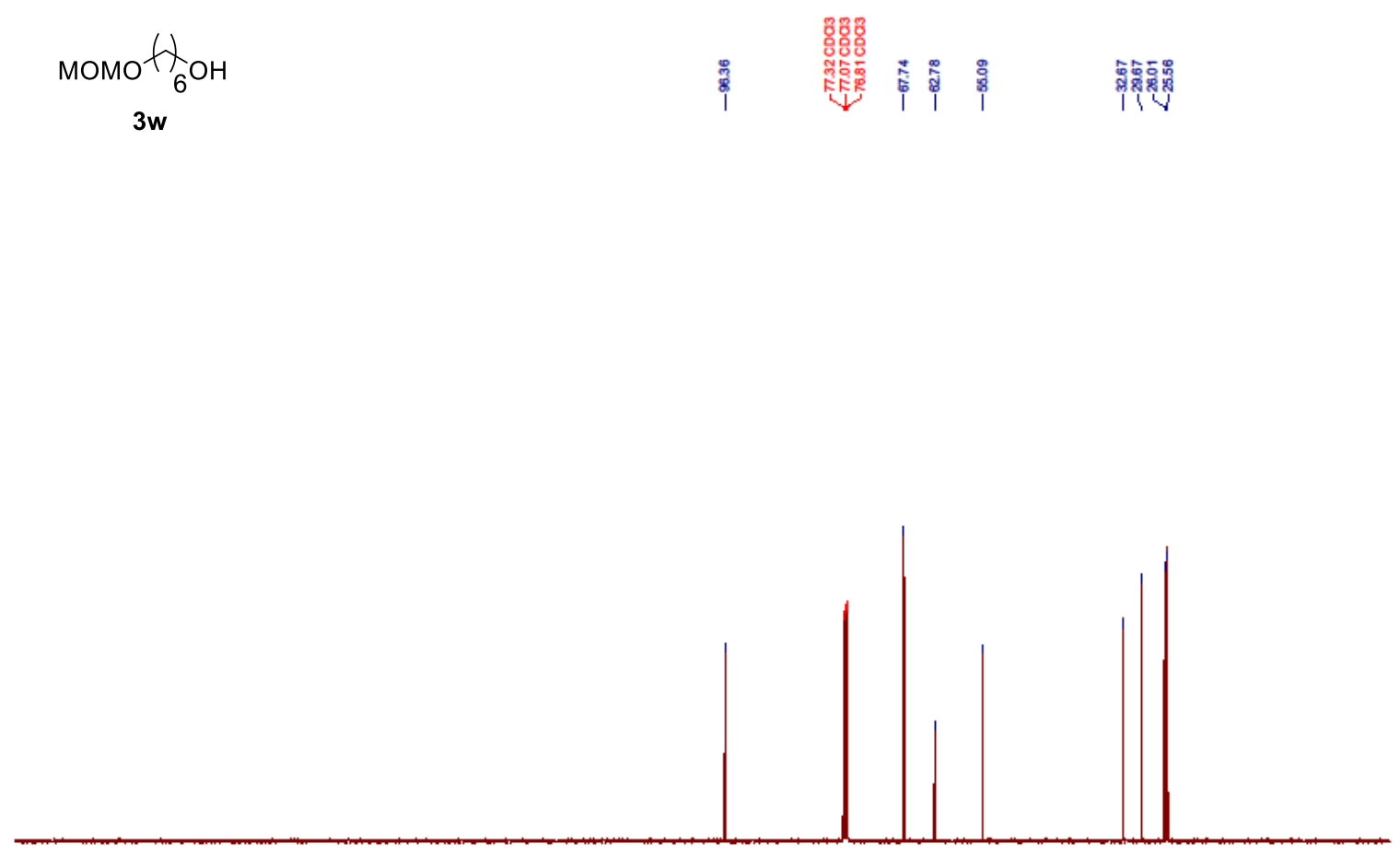

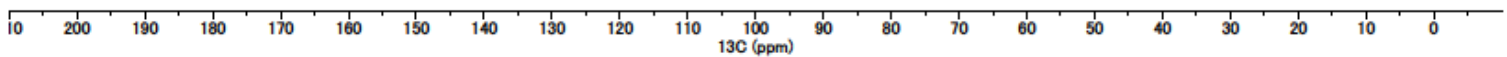


${ }^{1} \mathrm{H}$ NMR spectrum in $\mathrm{CDCl}_{3}(500 \mathrm{MHz})$

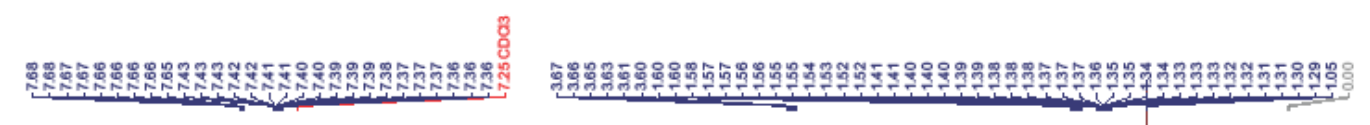

TBDPSO ${ }_{6} \mathrm{OH}$

$3 \mathbf{x}$

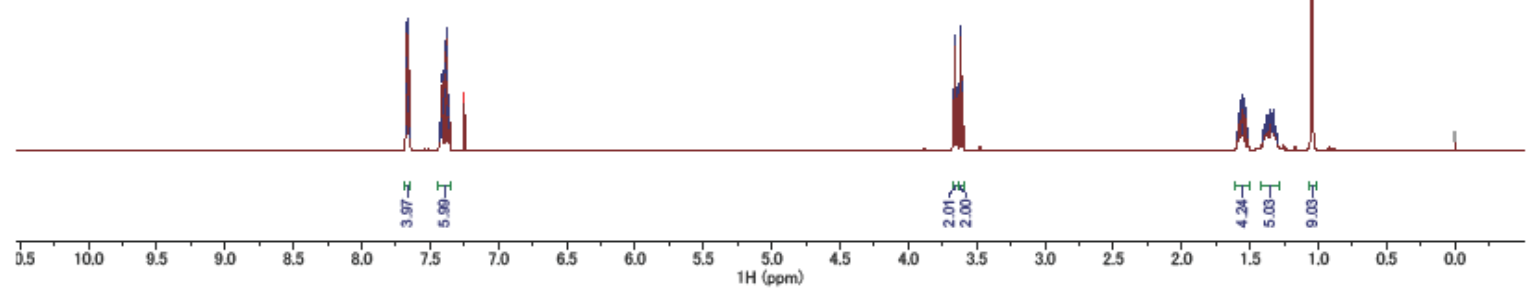

${ }^{13} \mathrm{C}$ NMR spectrum in $\mathrm{CDCl}_{3}(125 \mathrm{MHz})$

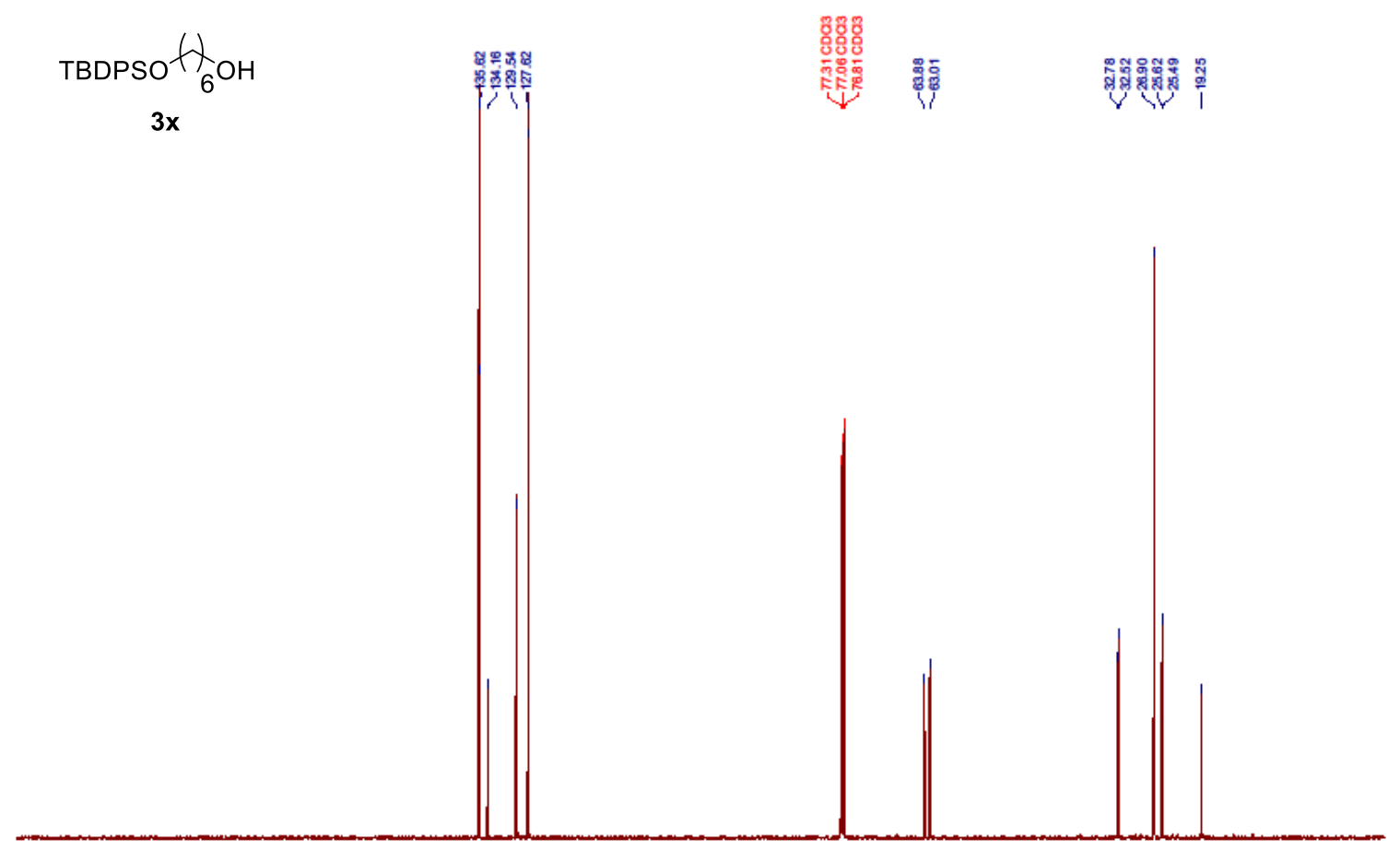

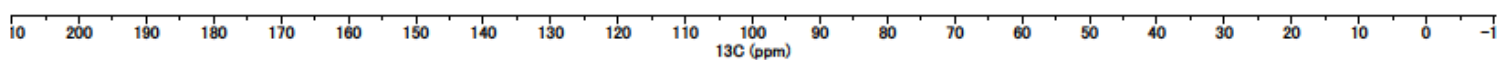


${ }^{1} \mathrm{H}$ NMR spectrum in $\mathrm{CDCl}_{3}(500 \mathrm{MHz})$

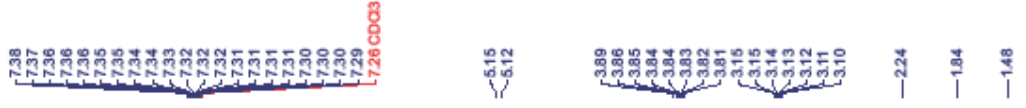<smiles>OC1CCN(C2CC2)CC1</smiles>

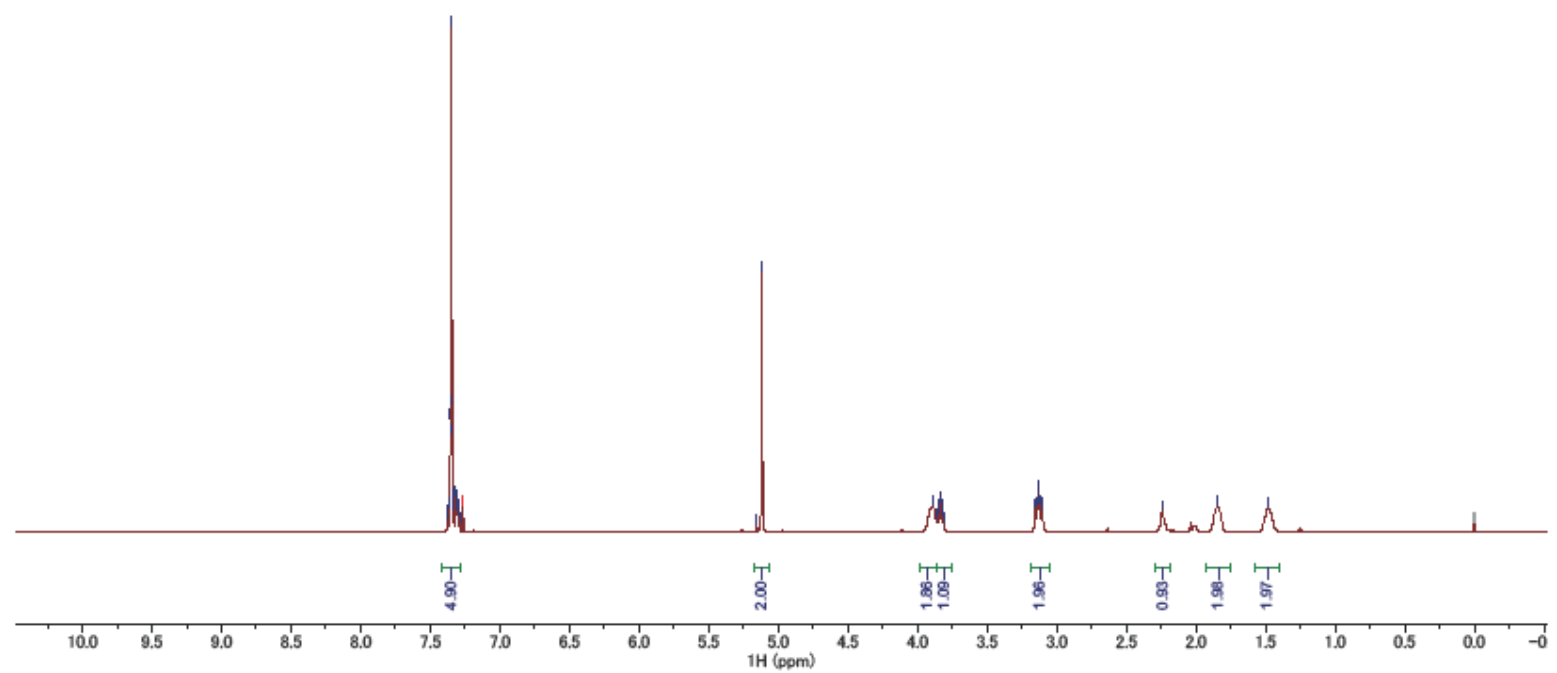

${ }^{13} \mathrm{C}$ NMR spectrum in $\mathrm{CDCl}_{3}(125 \mathrm{MHz})$

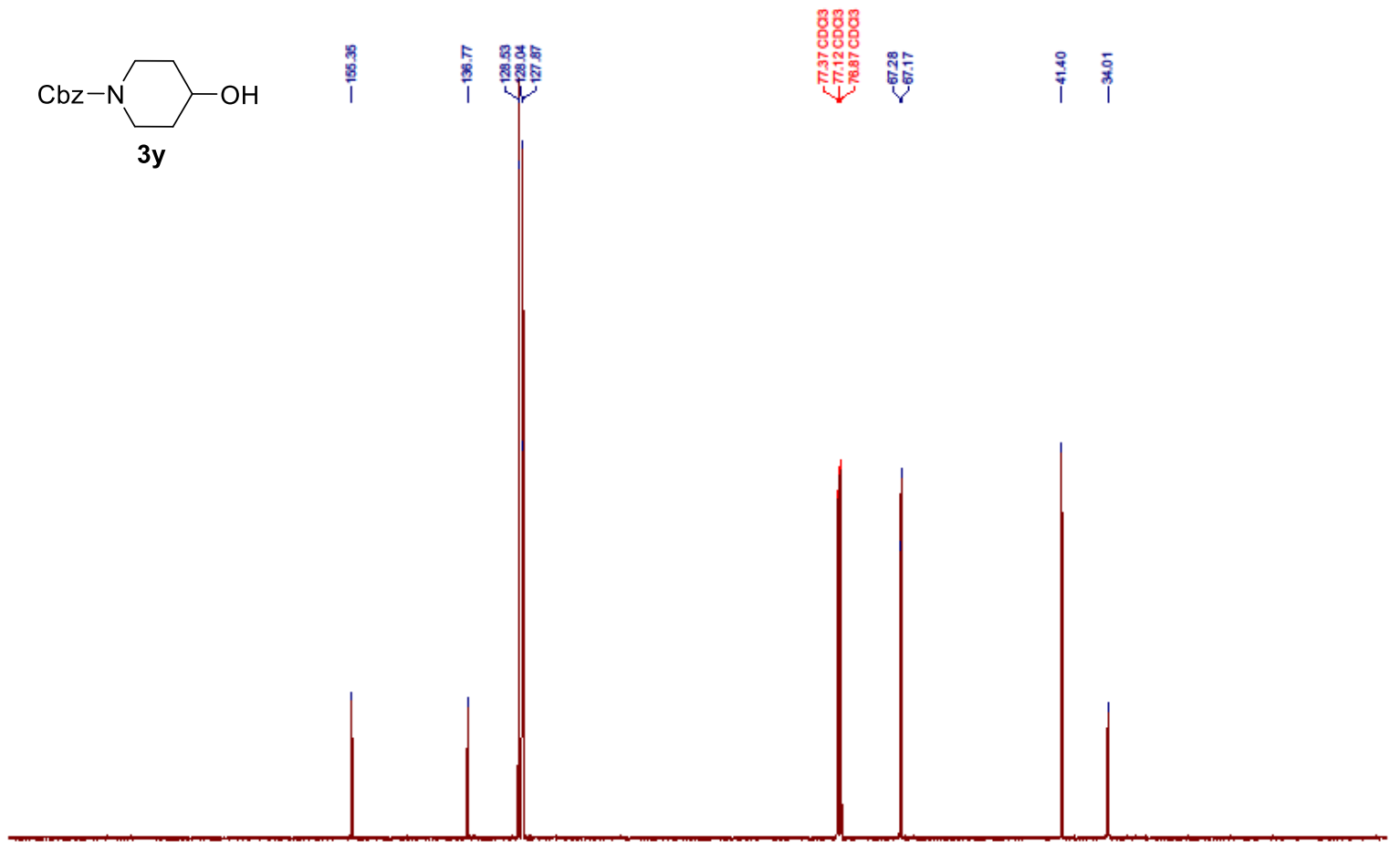

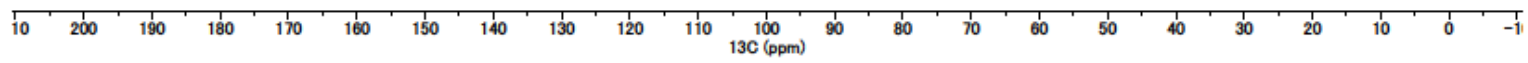


${ }^{1} \mathrm{H}$ NMR spectrum in $\mathrm{CDCl}_{3}(500 \mathrm{MHz})$

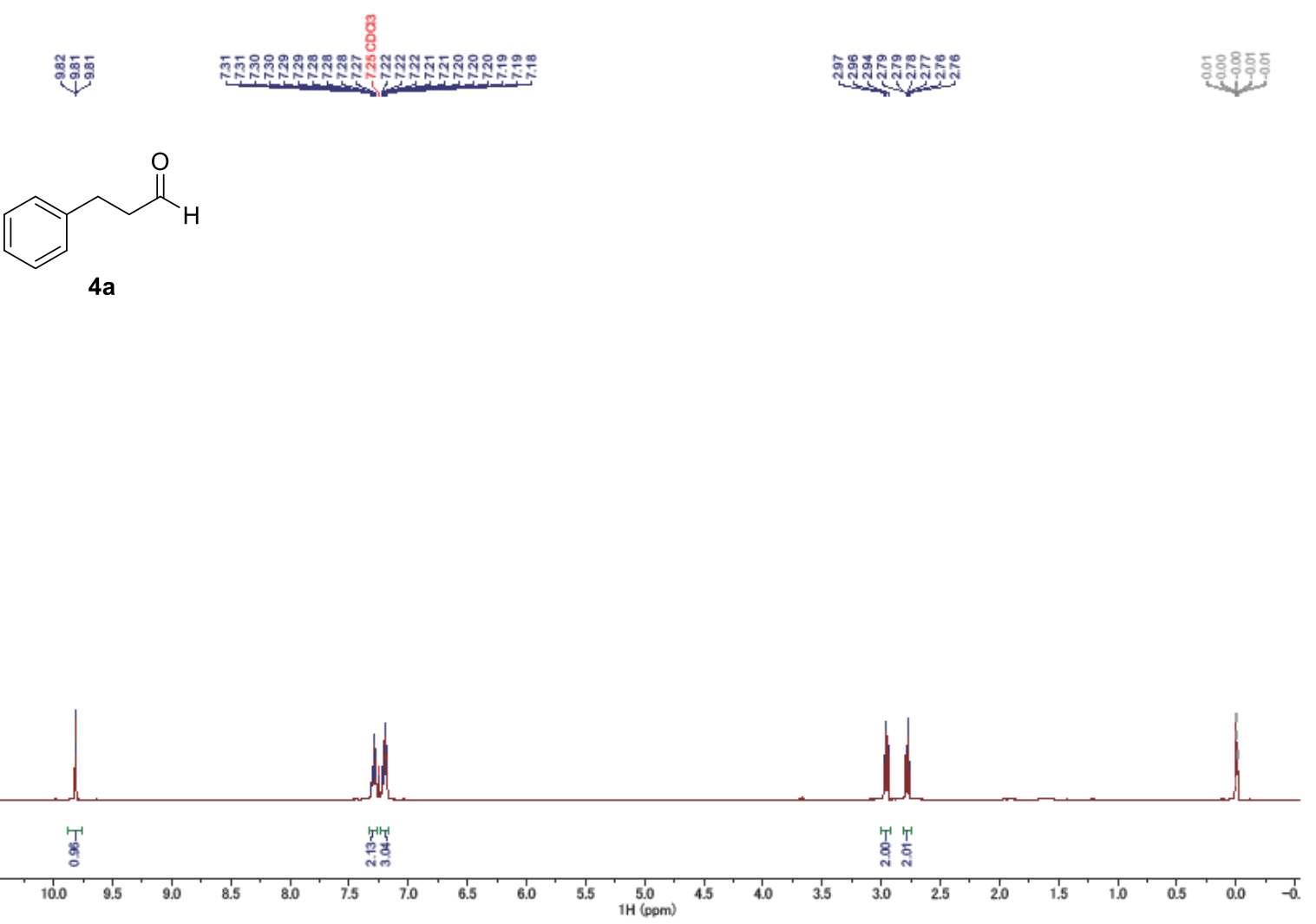

${ }^{13} \mathrm{C}$ NMR spectrum in $\mathrm{CDCl}_{3}(125 \mathrm{MHz})$

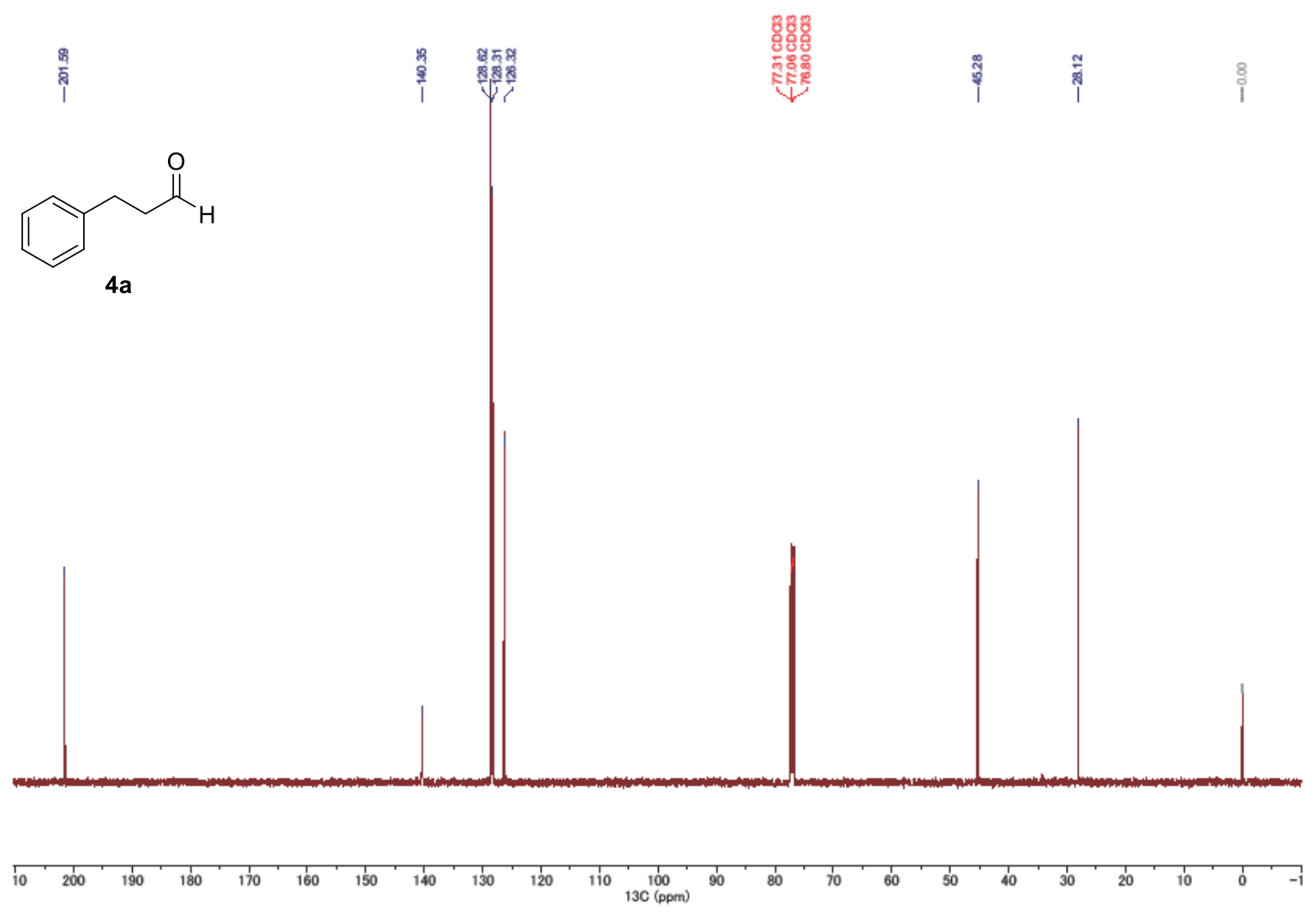


${ }^{1} \mathrm{H}$ NMR spectrum in $\mathrm{CDCl}_{3}(500 \mathrm{MHz})$

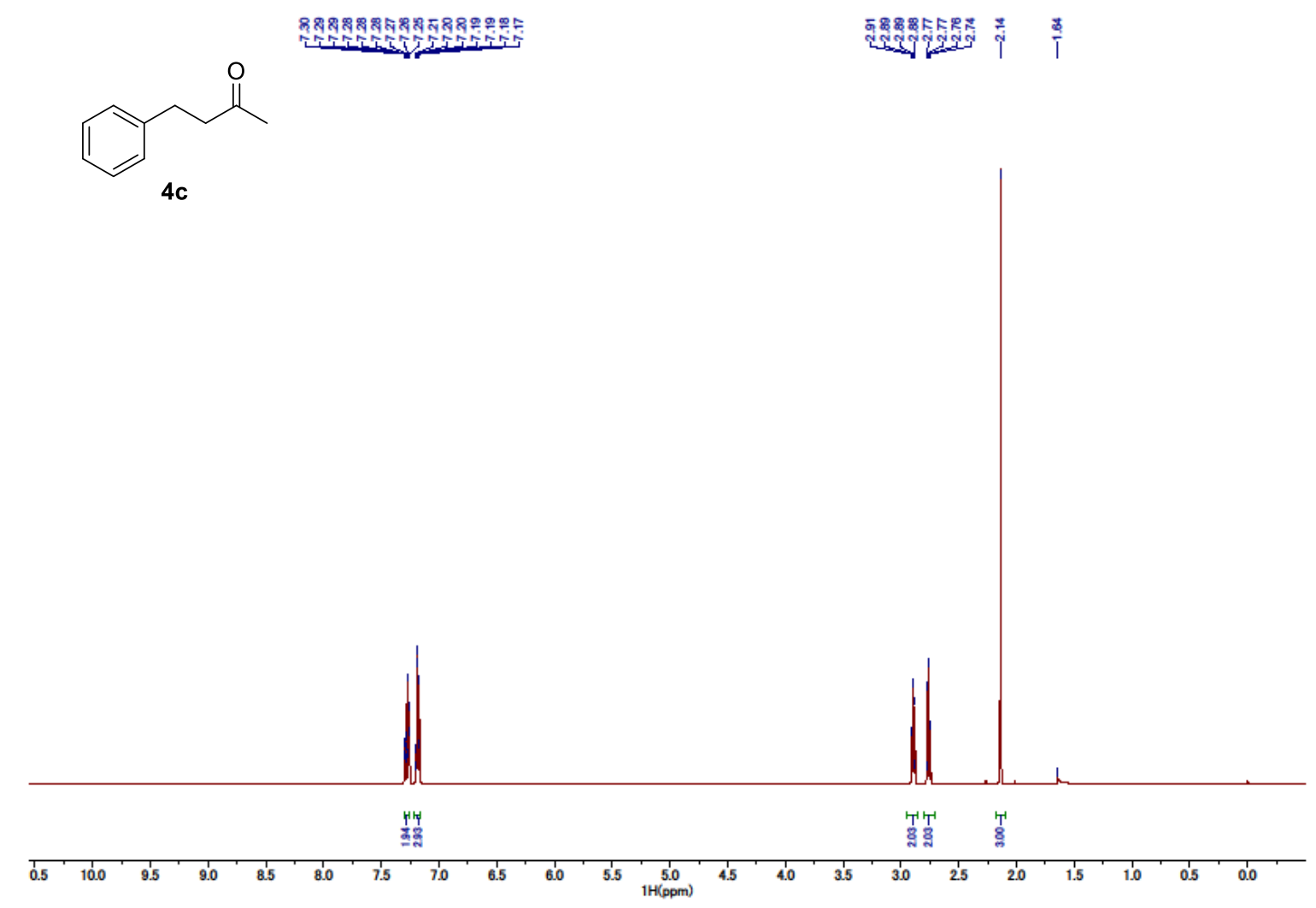

${ }^{13} \mathrm{C}$ NMR spectrum in $\mathrm{CDCl}_{3}(125 \mathrm{MHz})$

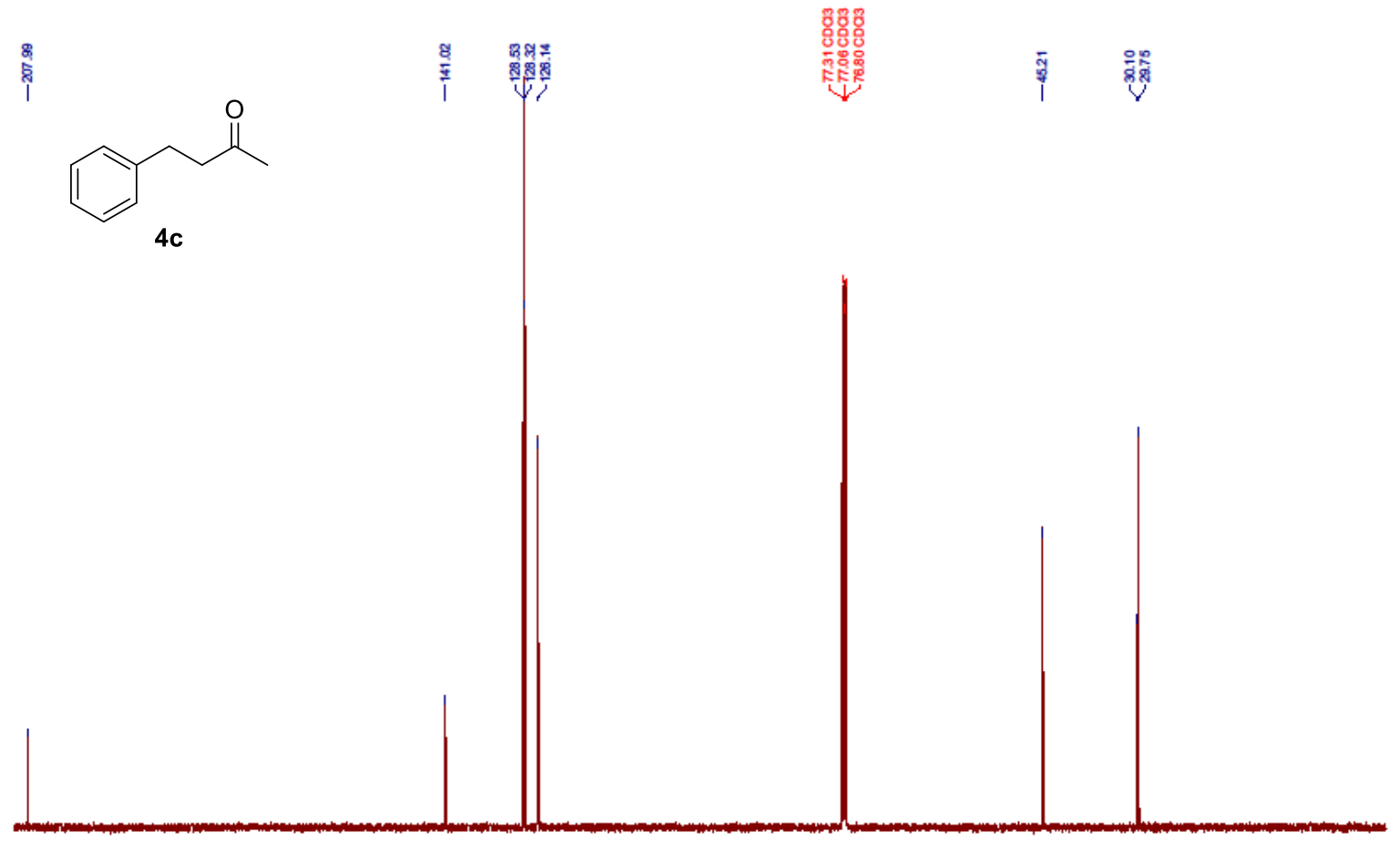

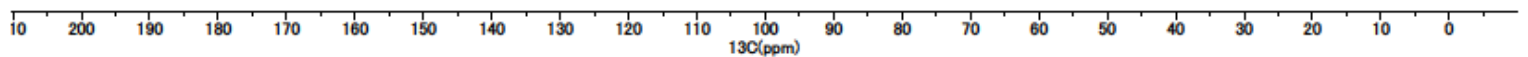


${ }^{1} \mathrm{H}$ NMR spectrum in $\mathrm{CDCl}_{3}(500 \mathrm{MHz})$
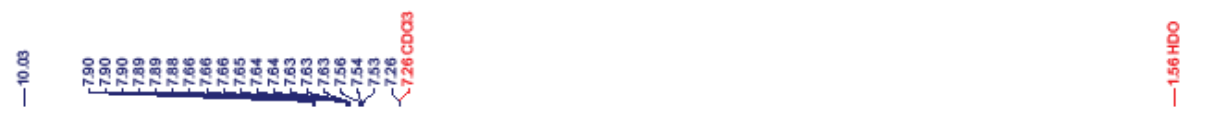<smiles>O=Cc1ccccc1</smiles>

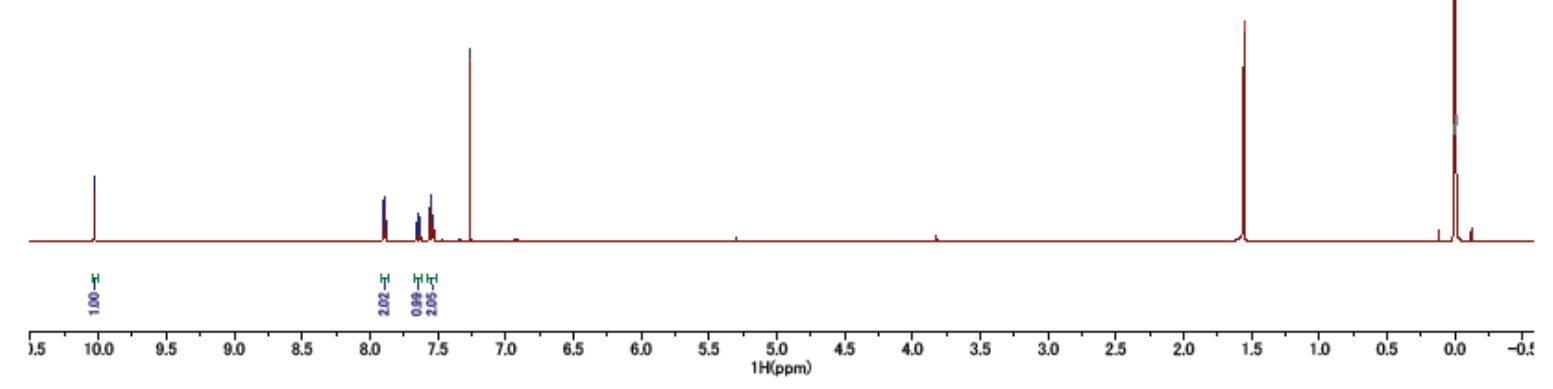

${ }^{13} \mathrm{C}$ NMR spectrum in $\mathrm{CDCl}_{3}(125 \mathrm{MHz})$<smiles>O=Cc1ccccc1</smiles>

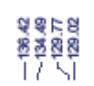

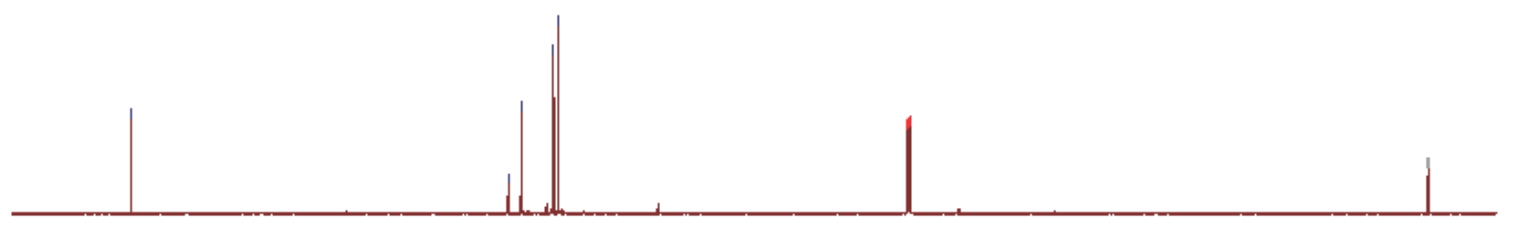

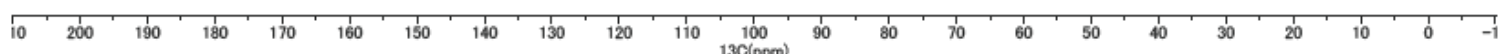


${ }^{1} \mathrm{H}$ NMR spectrum in $\mathrm{CDCl}_{3}(500 \mathrm{MHz})$

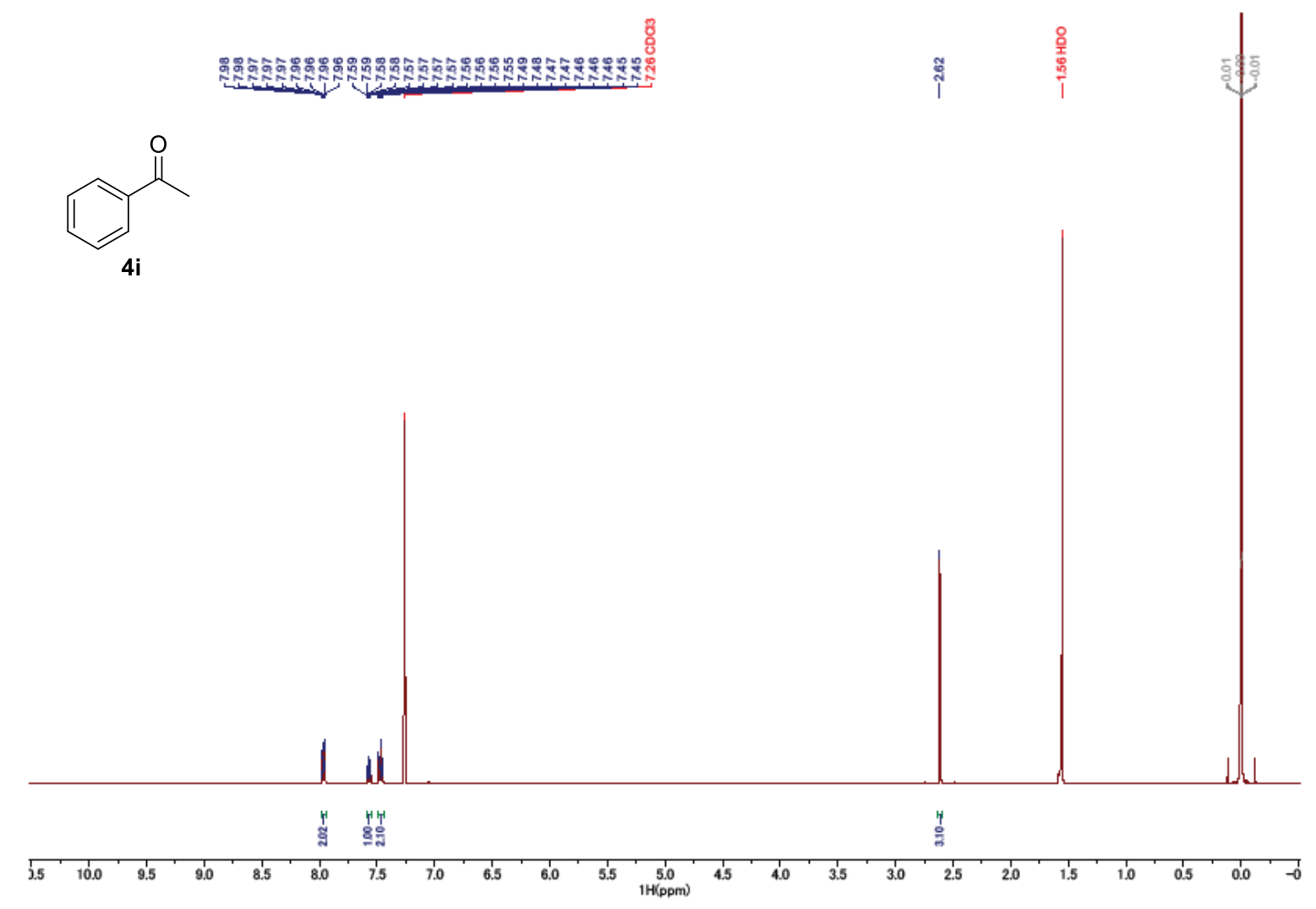

${ }^{13} \mathrm{C}$ NMR spectrum in $\mathrm{CDCl}_{3}(125 \mathrm{MHz})$
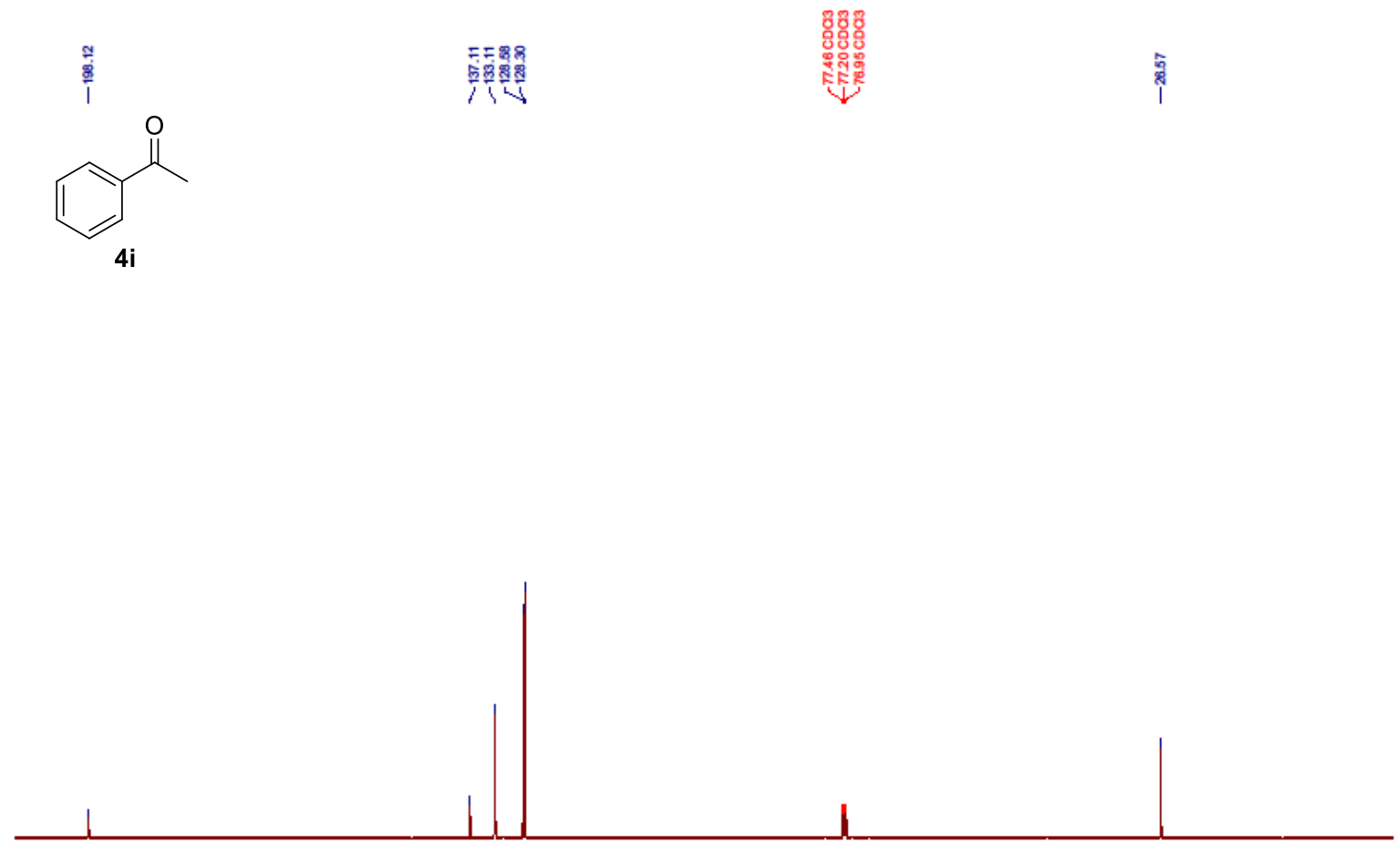

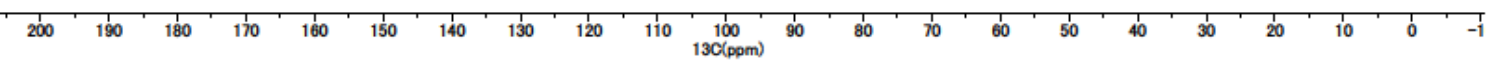


${ }^{1} \mathrm{H}$ NMR spectrum in $\mathrm{CDCl}_{3}(500 \mathrm{MHz})$

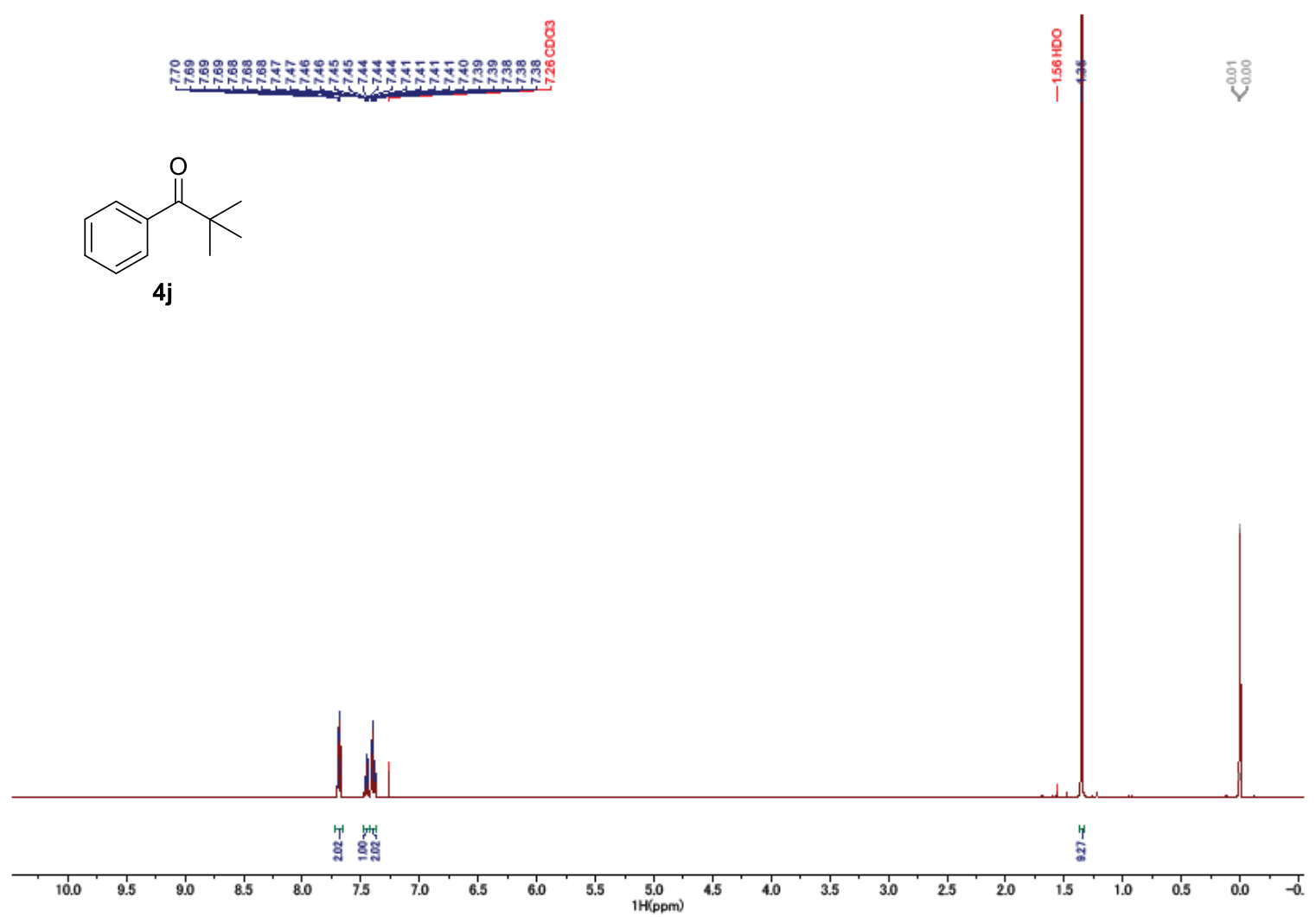

${ }^{13} \mathrm{C}$ NMR spectrum in $\mathrm{CDCl}_{3}(125 \mathrm{MHz})$

要<smiles>CC(C)(C)C(=O)c1ccccc1</smiles>

$4 \mathrm{j}$

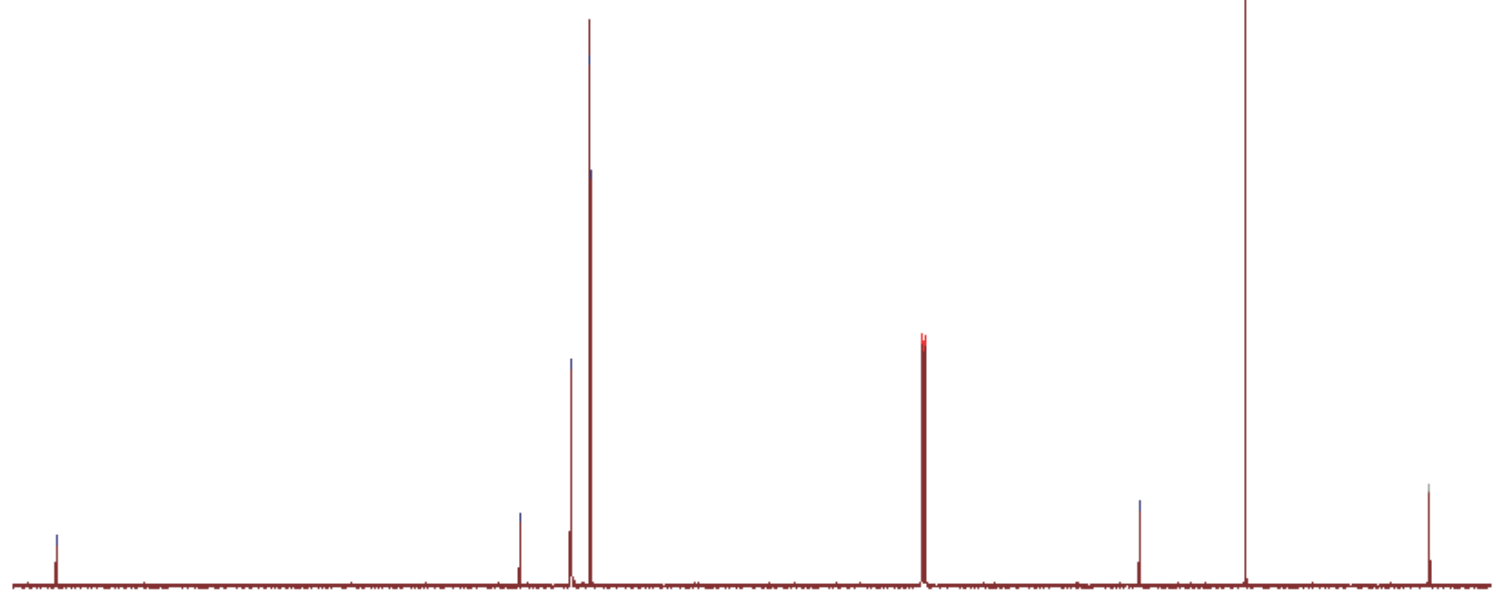

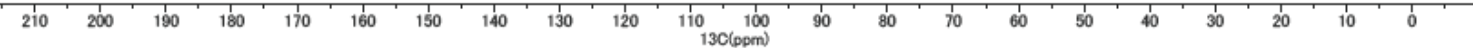


${ }^{1} \mathrm{H}$ NMR spectrum in $\mathrm{CDCl}_{3}(500 \mathrm{MHz})$
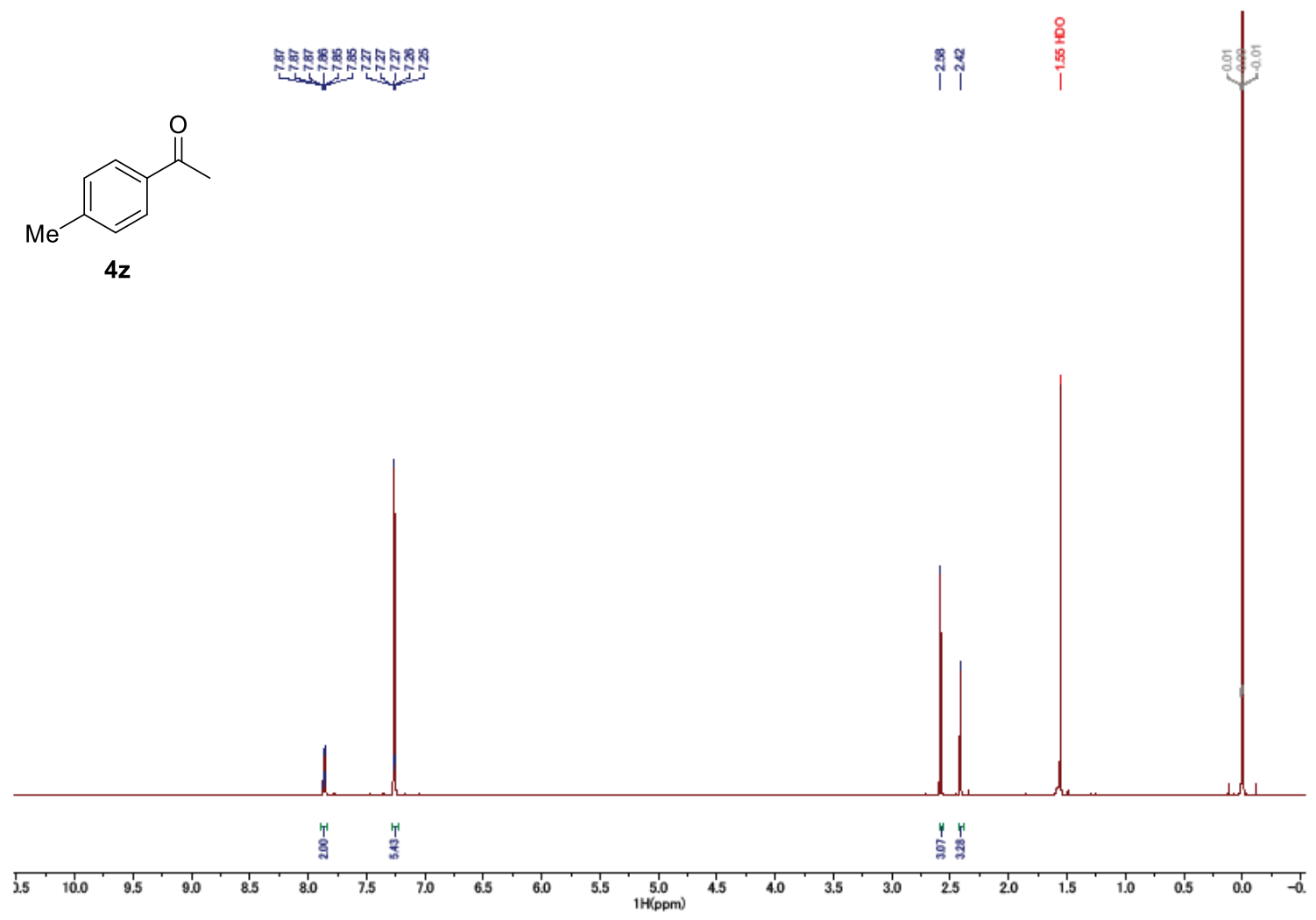

${ }^{13} \mathrm{C}$ NMR spectrum in $\mathrm{CDCl}_{3}(75 \mathrm{MHz})$

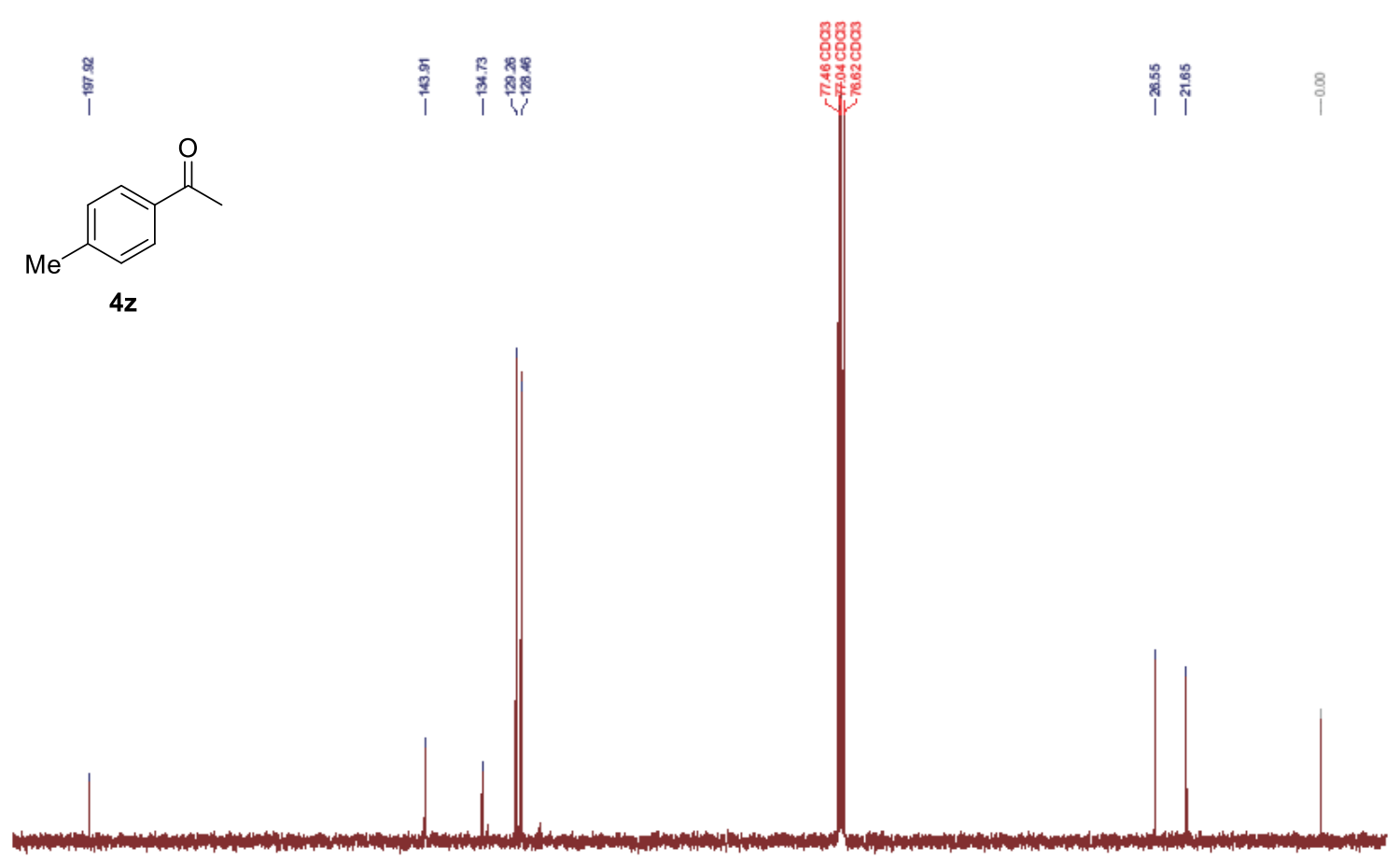

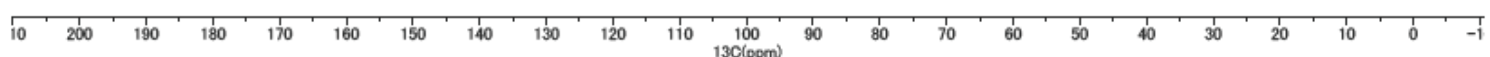


${ }^{1} \mathrm{H}$ NMR spectrum in $\mathrm{CDCl}_{3}(500 \mathrm{MHz})$

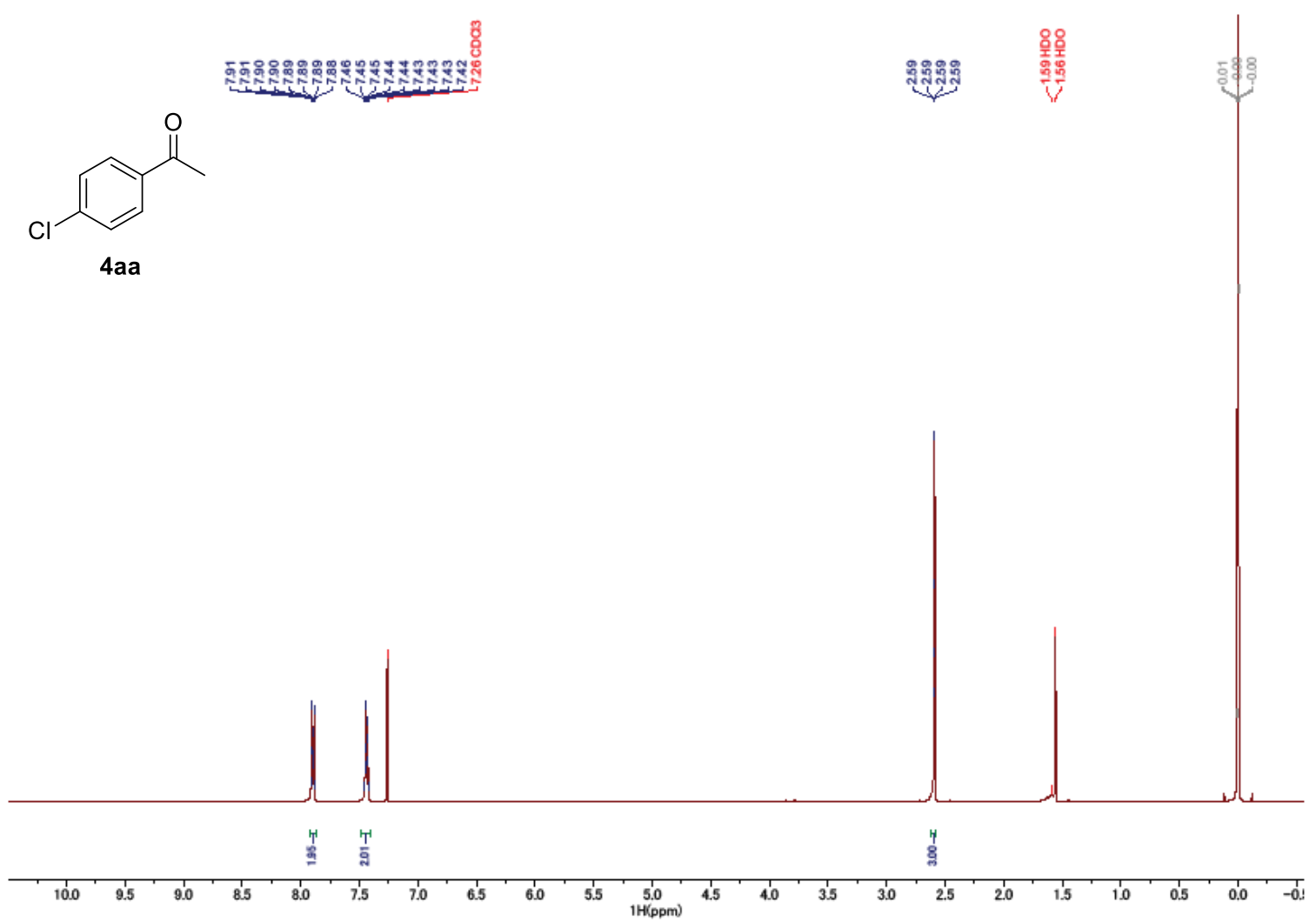

${ }^{13} \mathrm{C}$ NMR spectrum in $\mathrm{CDCl}_{3}(125 \mathrm{MHz})$
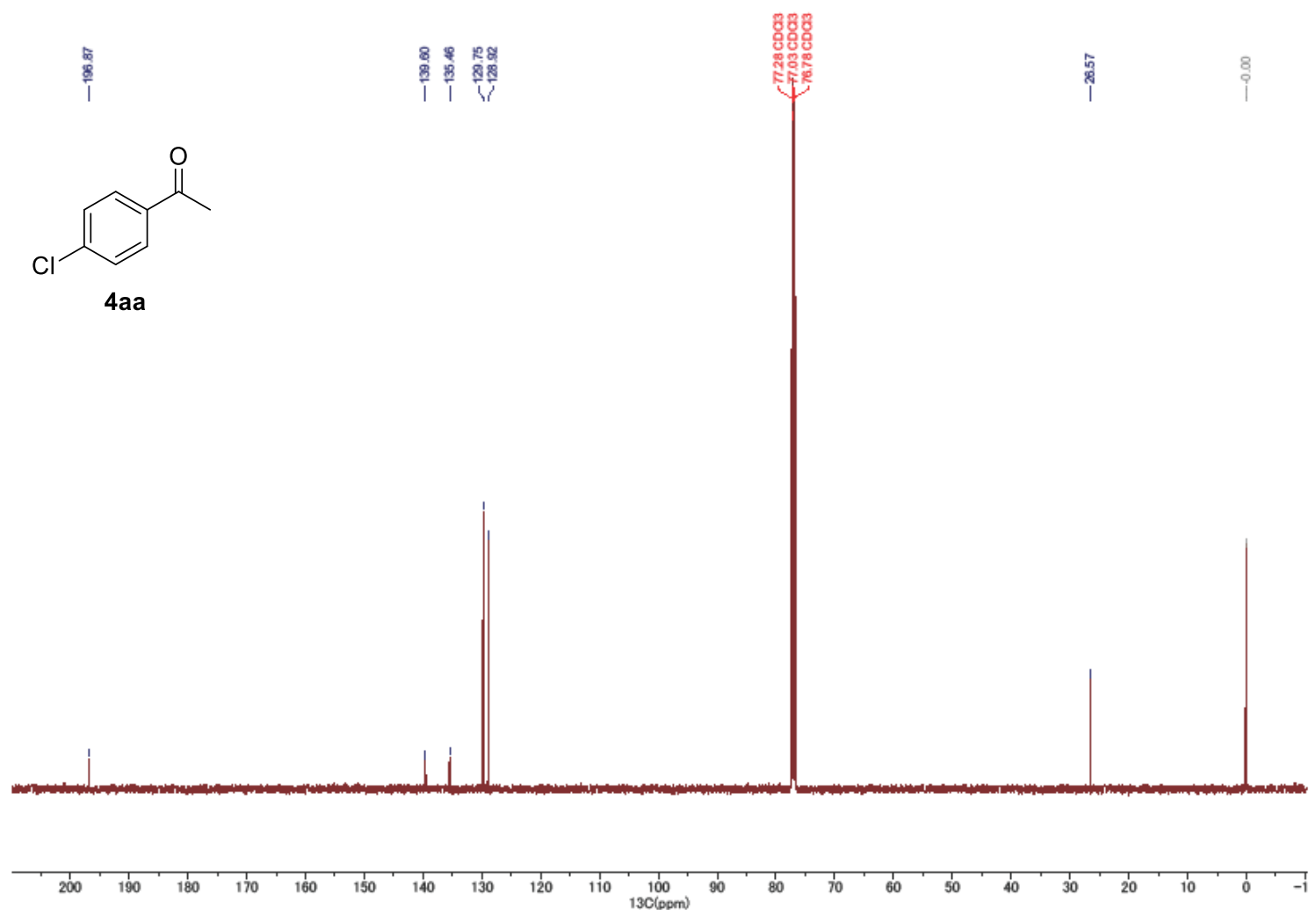
${ }^{1} \mathrm{H}$ NMR spectrum in $\mathrm{CDCl}_{3}(500 \mathrm{MHz})$
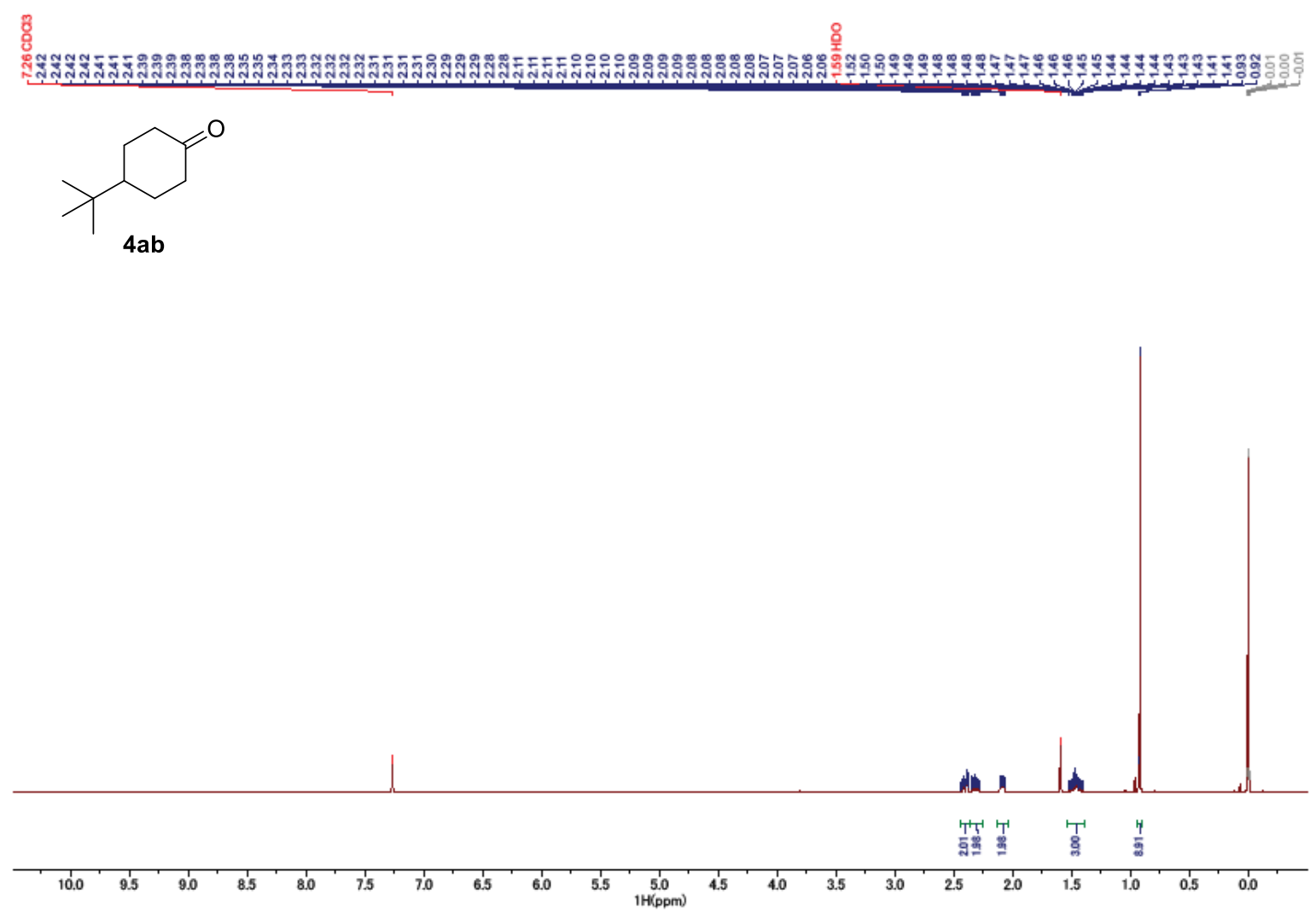

${ }^{13} \mathrm{C}$ NMR spectrum in $\mathrm{CDCl}_{3}(125 \mathrm{MHz})$
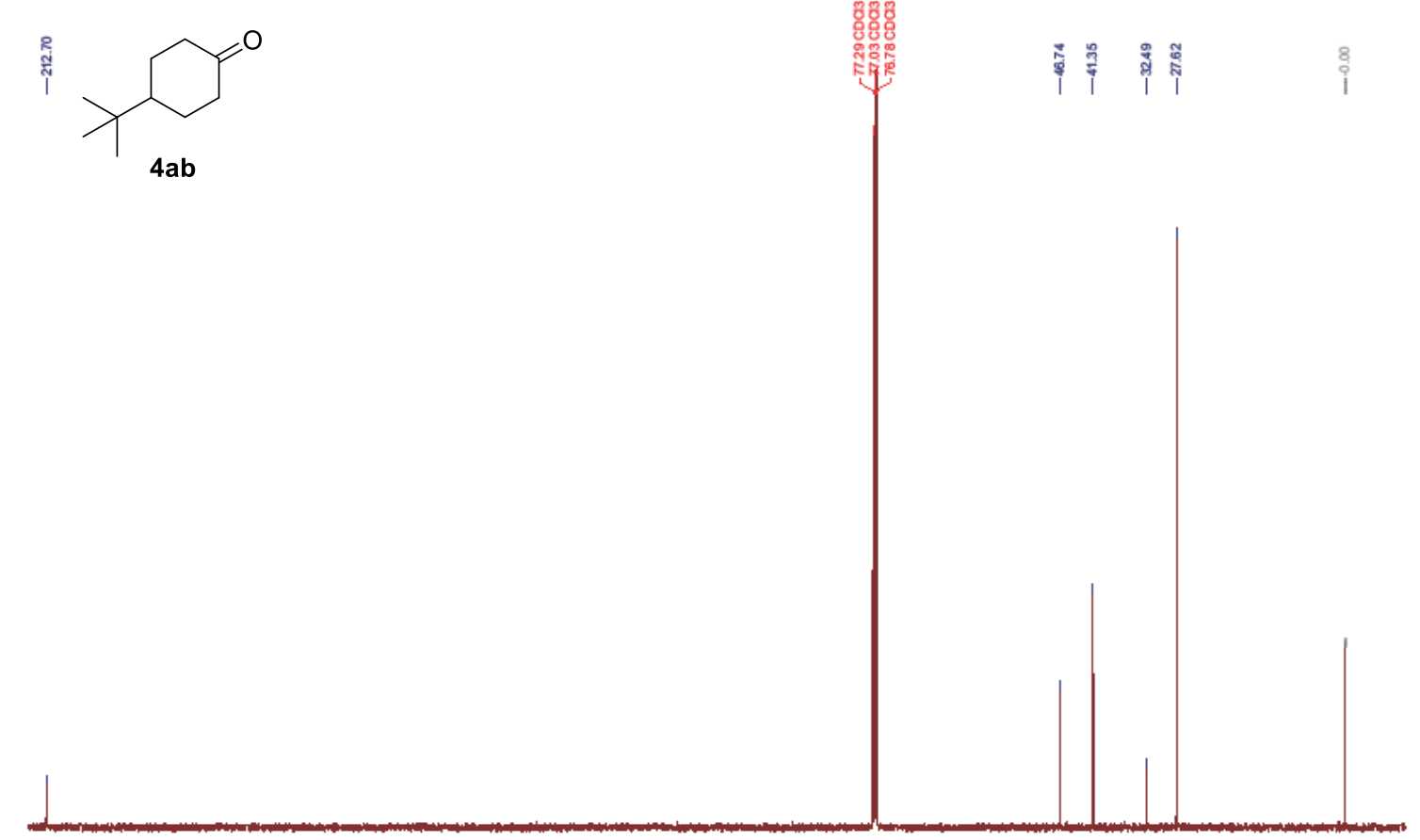

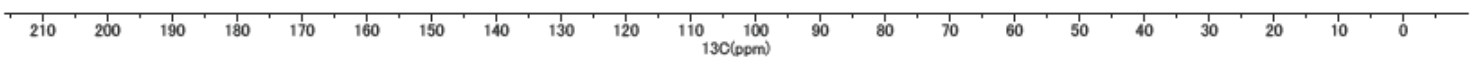


${ }^{1} \mathrm{H}$ NMR spectrum in $\mathrm{CDCl}_{3}(500 \mathrm{MHz})$

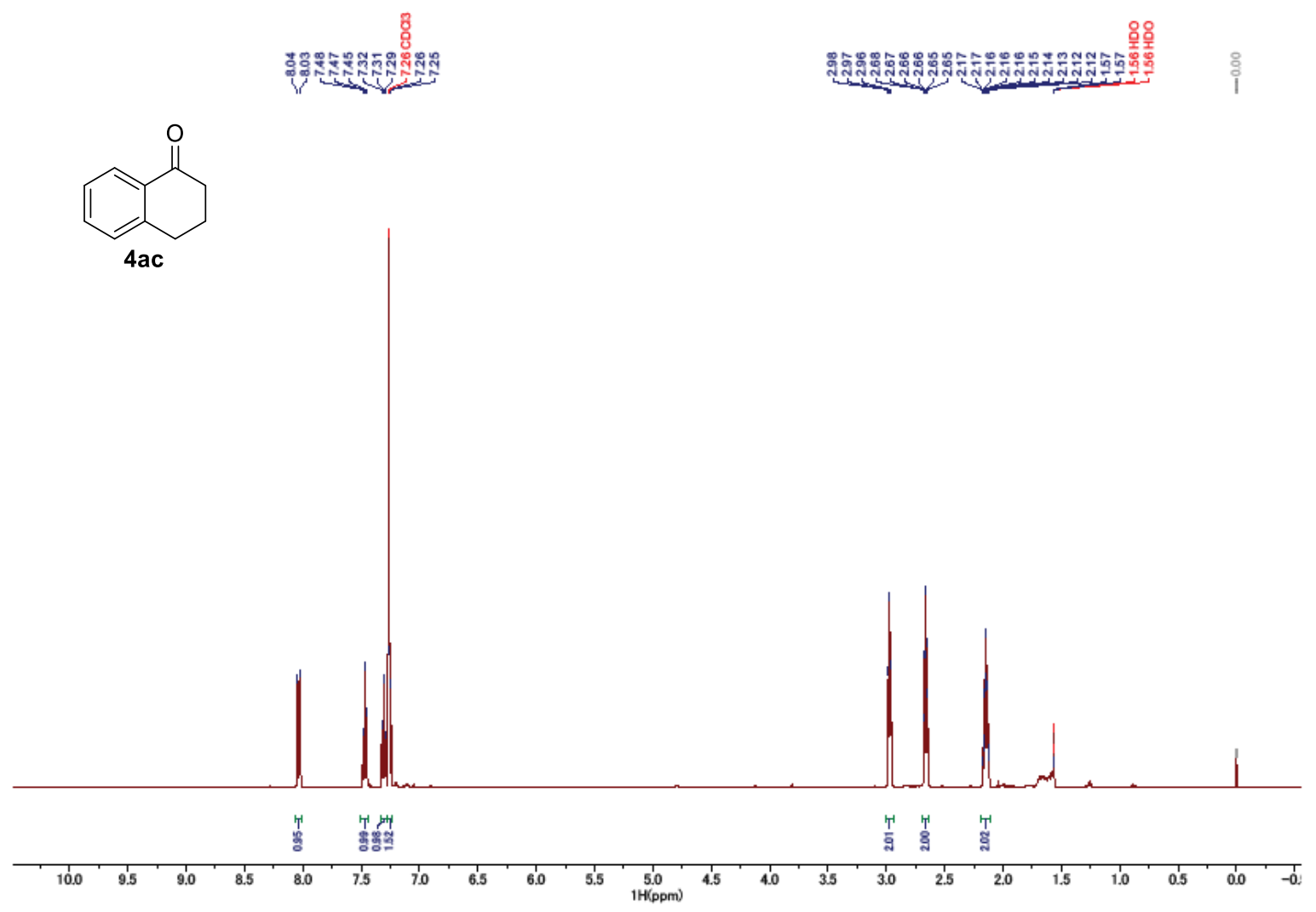

${ }^{13} \mathrm{C}$ NMR spectrum in $\mathrm{CDCl}_{3}(125 \mathrm{MHz})$<smiles>O=C1CCCc2ccccc21</smiles>

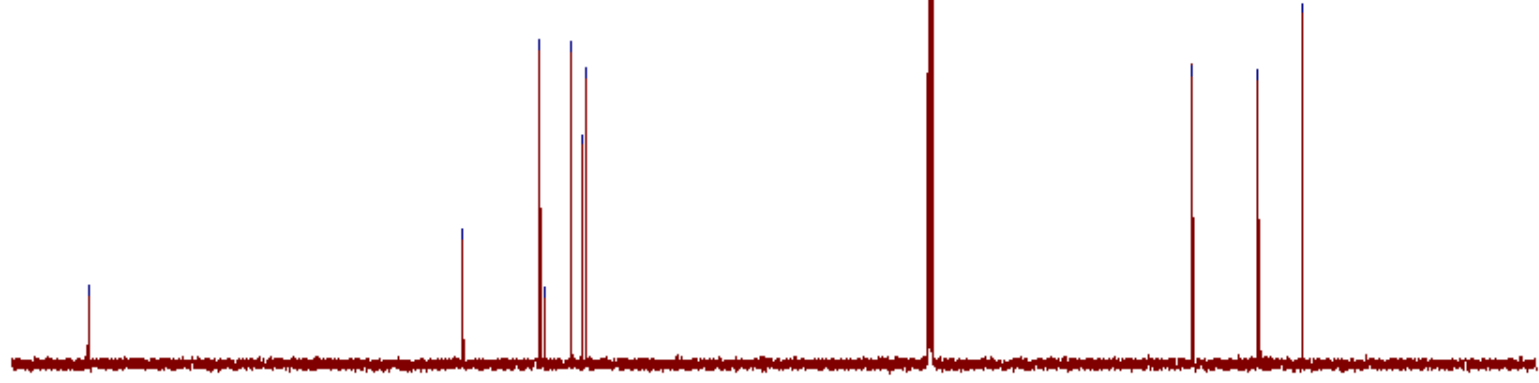

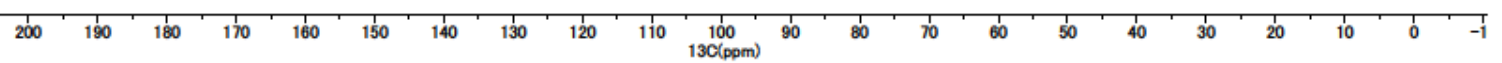


${ }^{1} \mathrm{H}$ NMR spectrum in $\mathrm{CDCl}_{3}(500 \mathrm{MHz})$

8

춘

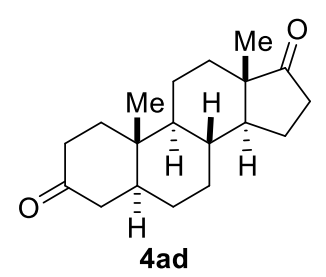

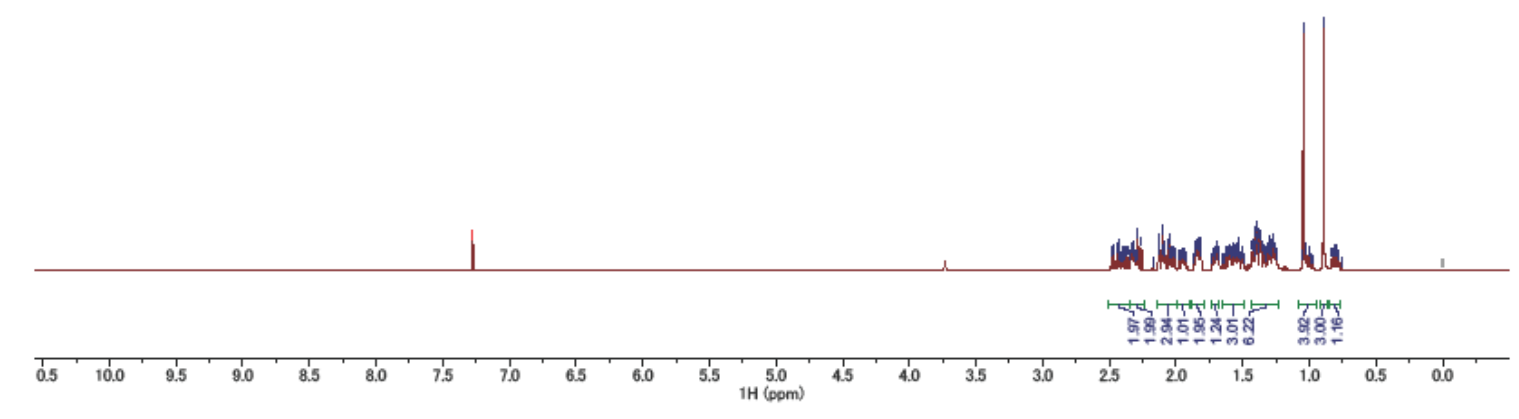

${ }^{13} \mathrm{C}$ NMR spectrum in $\mathrm{CDCl}_{3}(125 \mathrm{MHz})$

$$
\text { 홍 }
$$
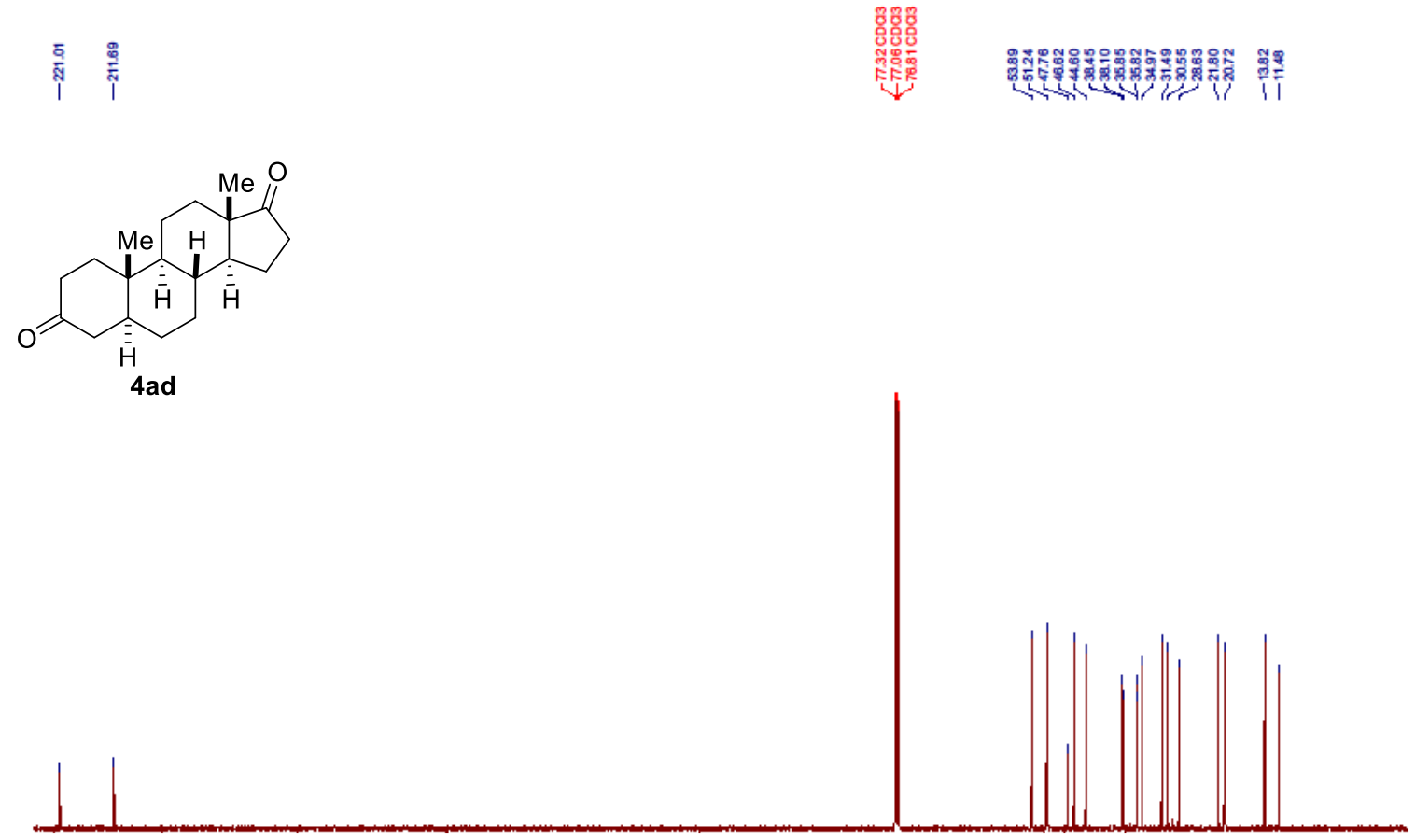

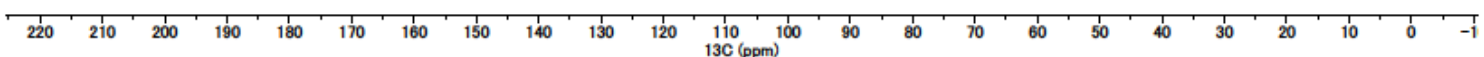


${ }^{1} \mathrm{H}$ NMR spectrum in $\mathrm{CDCl}_{3}(300 \mathrm{MHz})$

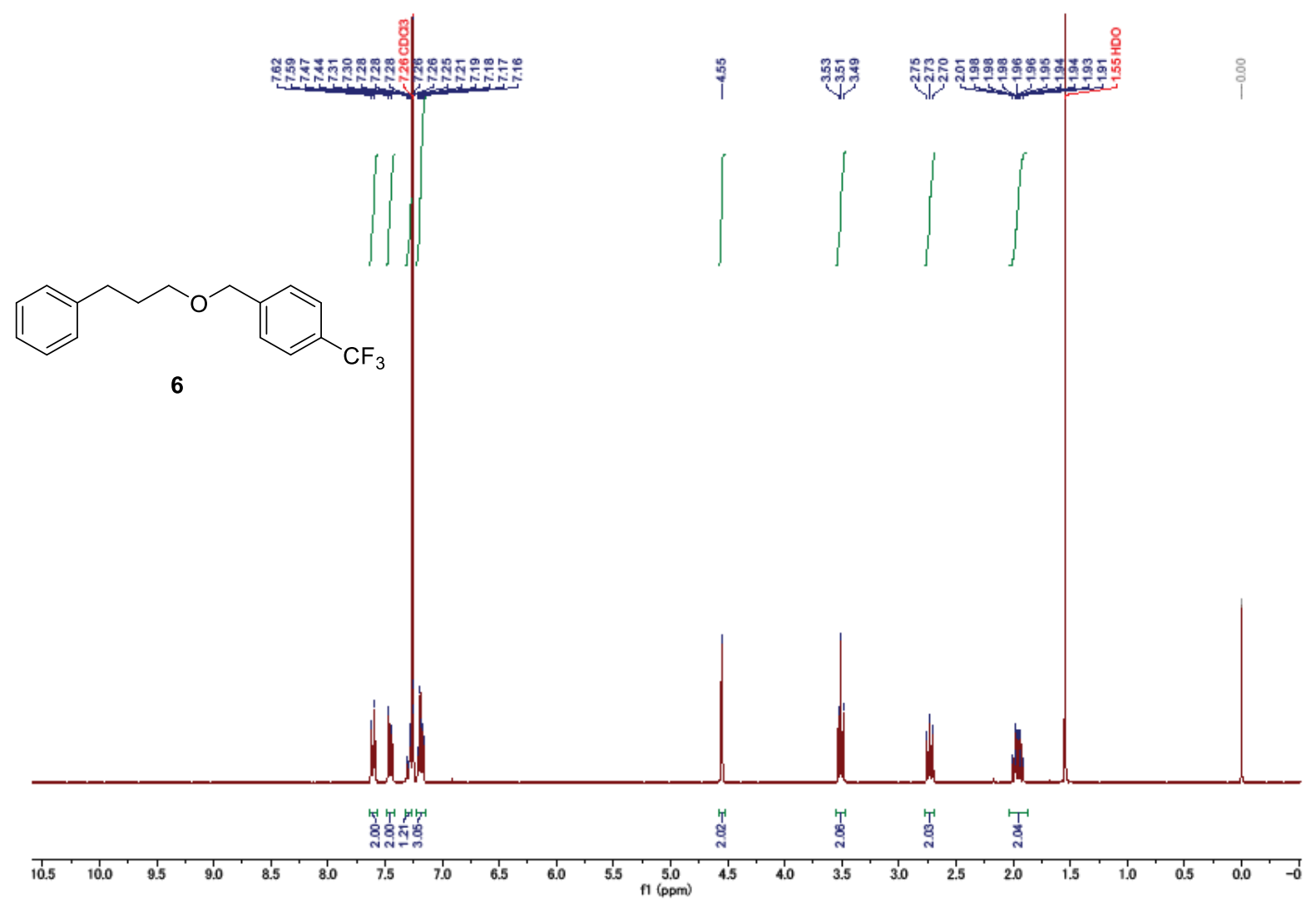

${ }^{13} \mathrm{C}$ NMR spectrum in $\mathrm{CDCl}_{3}(75 \mathrm{MHz})$
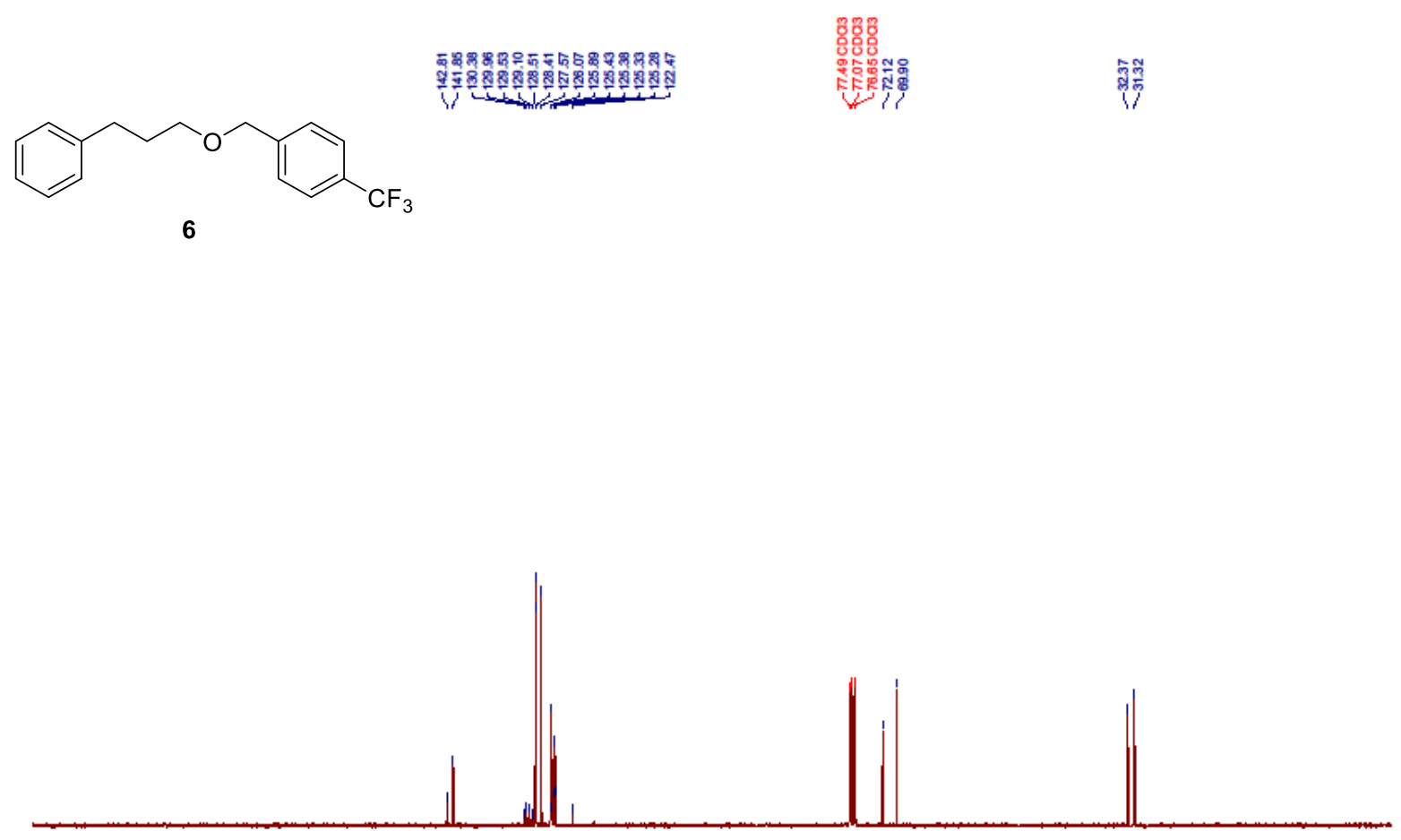

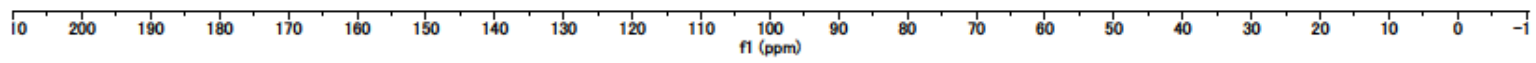


${ }^{1} \mathrm{H}$ NMR spectrum in $\mathrm{CDCl}_{3}(300 \mathrm{MHz})$
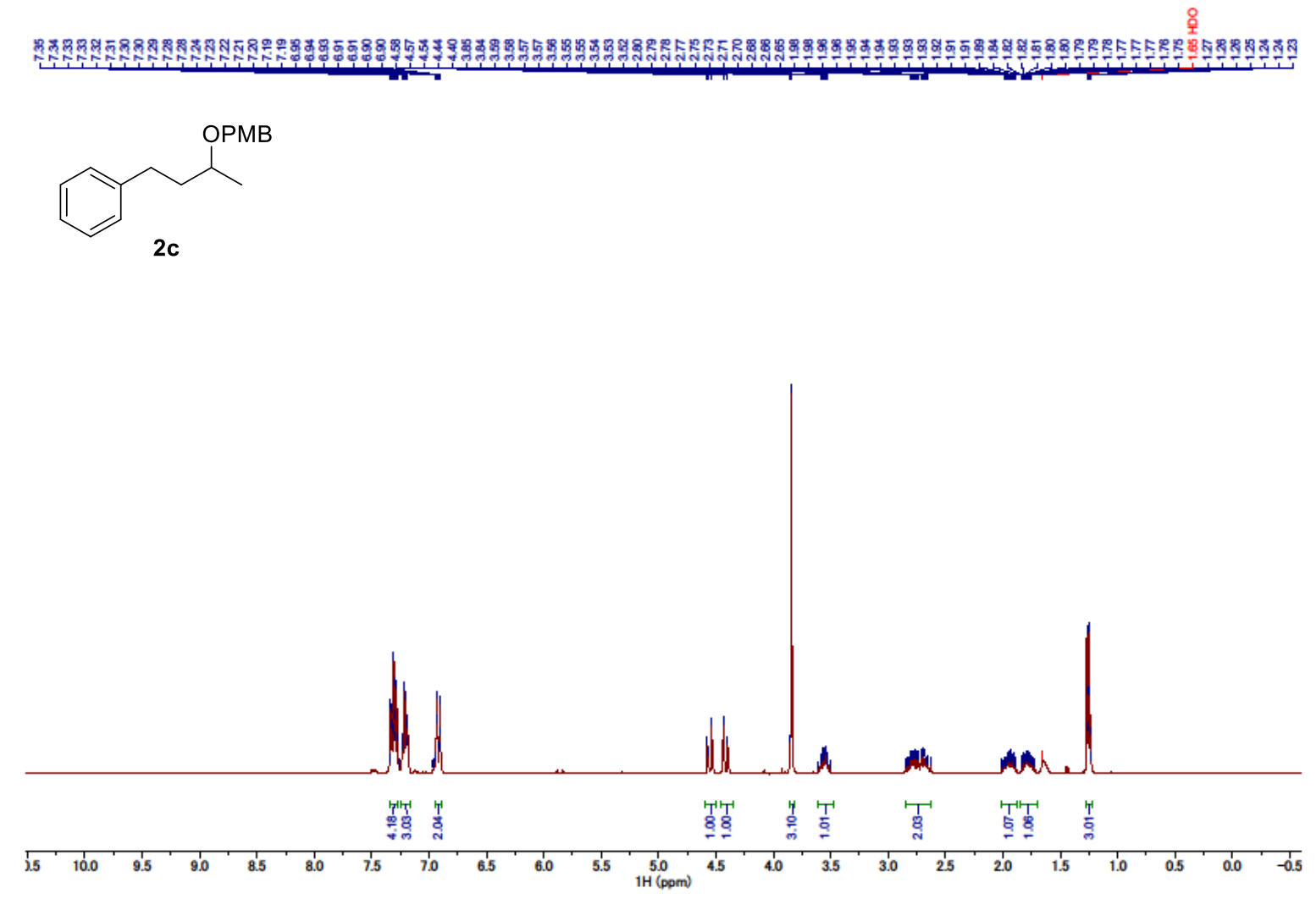

${ }^{13} \mathrm{C}$ NMR spectrum in $\mathrm{CDCl}_{3}(75 \mathrm{MHz})$
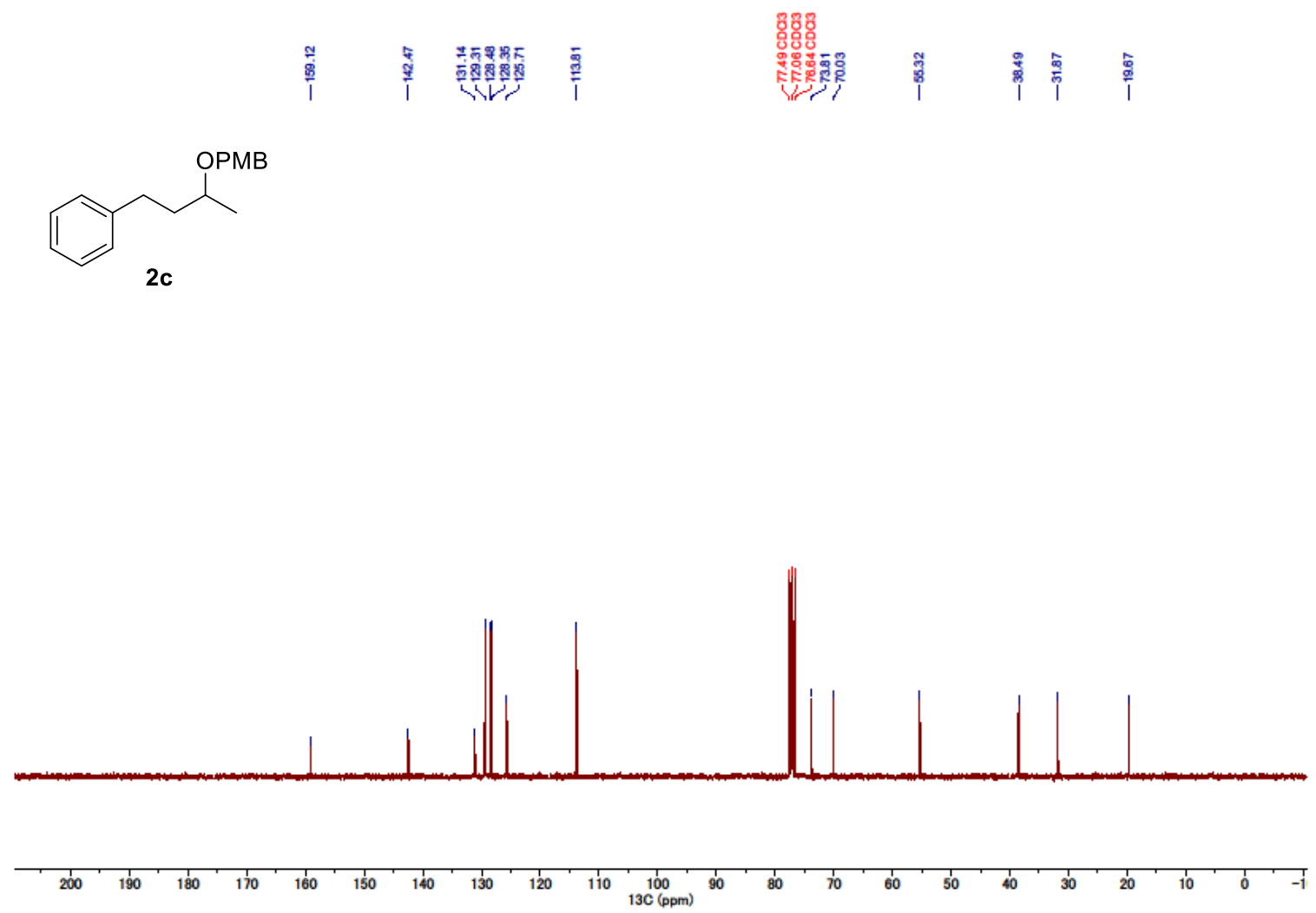
${ }^{1} \mathrm{H}$ NMR spectrum in $\mathrm{CDCl}_{3}(500 \mathrm{MHz})$

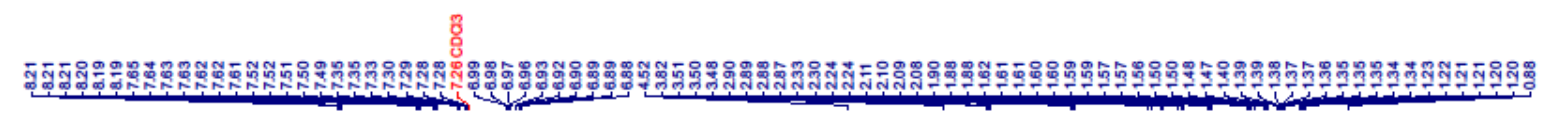<smiles>CCCCCCC1(C)CCC2c3ccc(OC(=O)c4ccccc4)cc3CCC2C1</smiles>

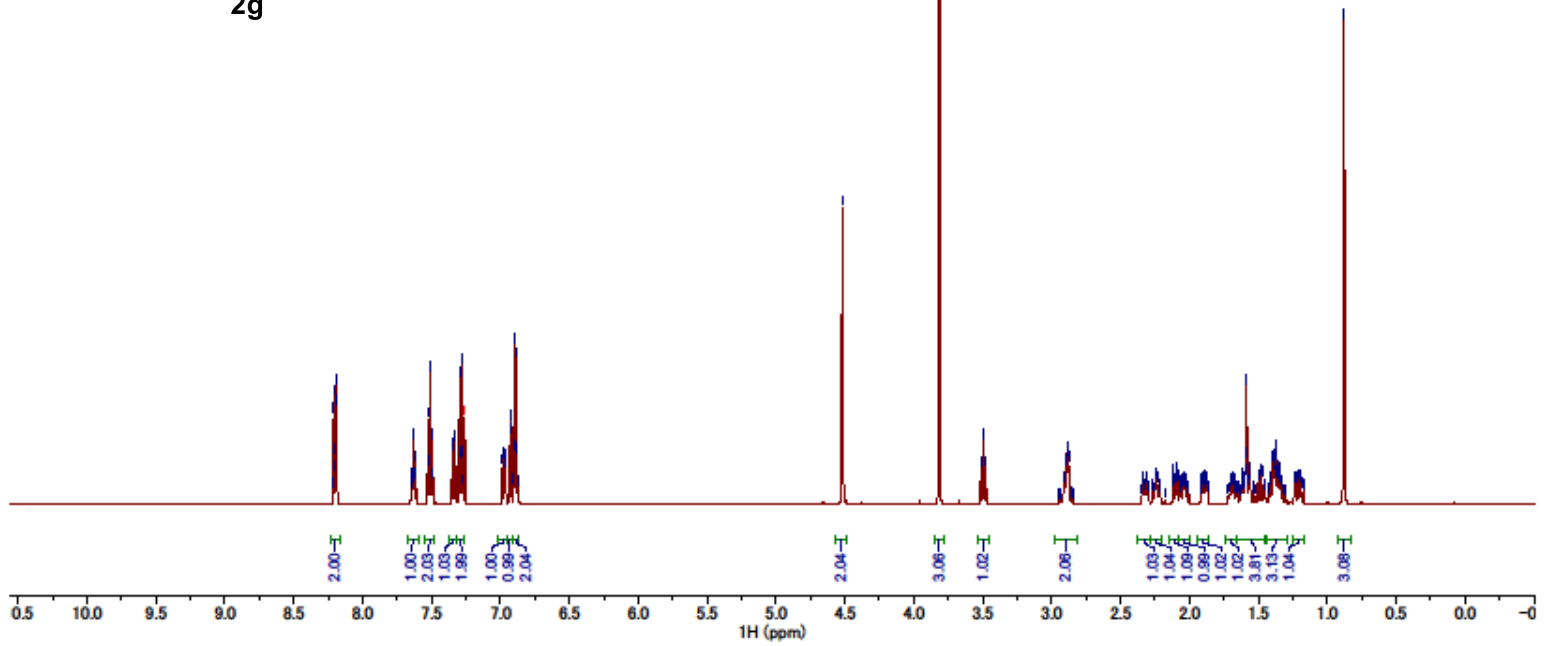

${ }^{13} \mathrm{C}$ NMR spectrum in $\mathrm{CDCl}_{3}(75 \mathrm{MHz})$
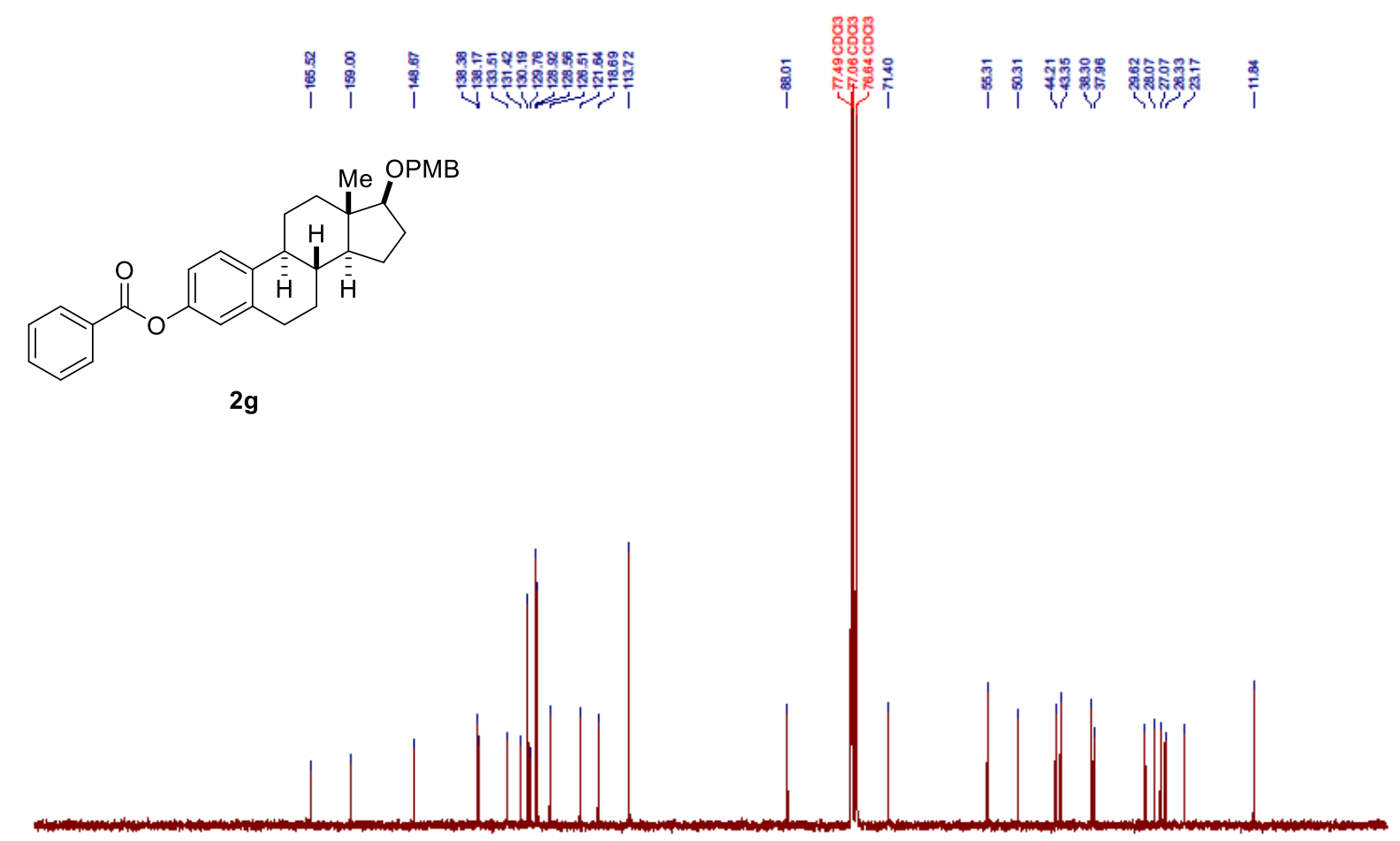

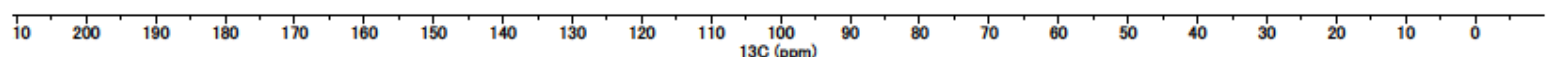


${ }^{1} \mathrm{H}$ NMR spectrum in $\mathrm{CDCl}_{3}(300 \mathrm{MHz})$

8.27.
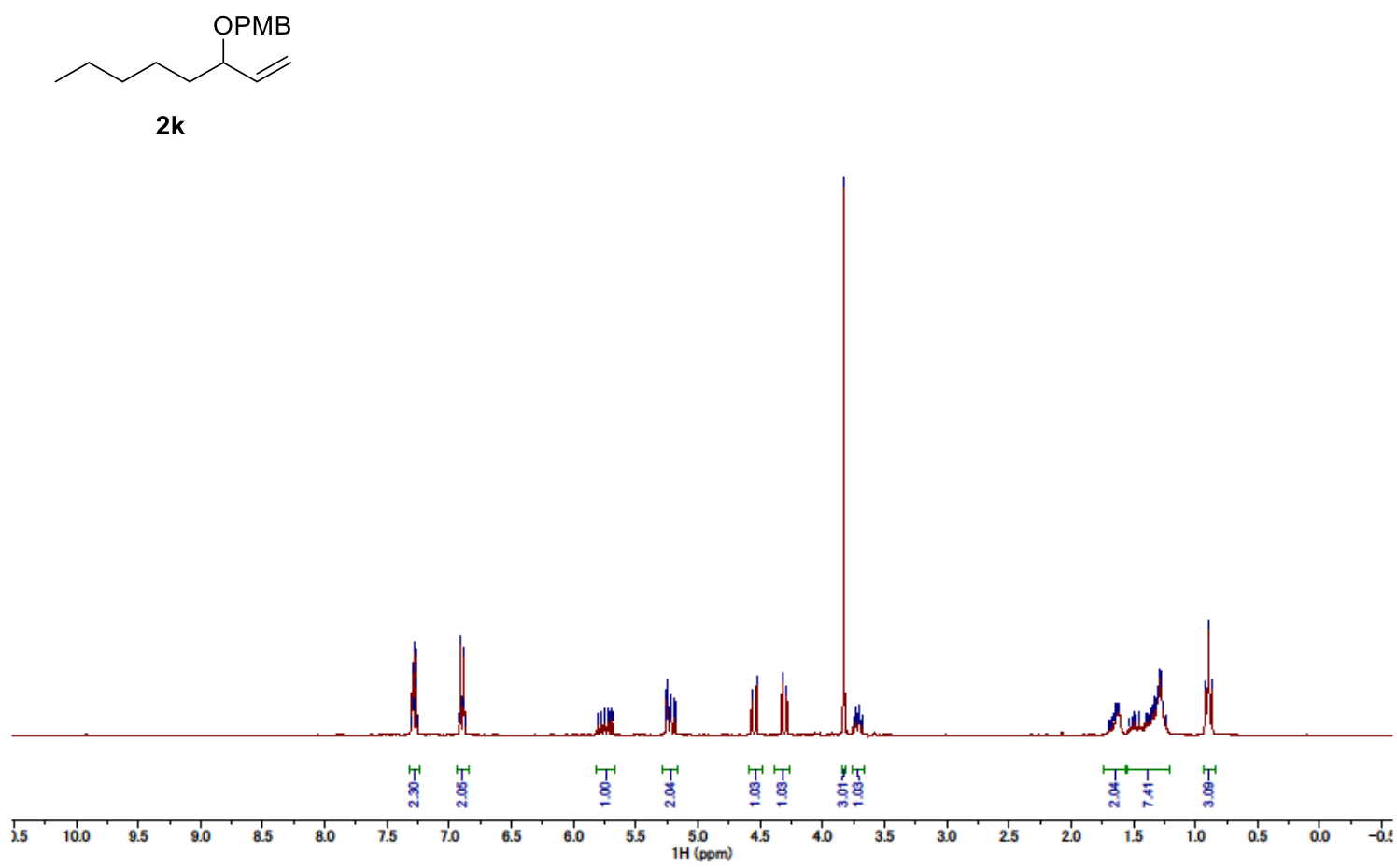

${ }^{13} \mathrm{C}$ NMR spectrum in $\mathrm{CDCl}_{3}(75 \mathrm{MHz})$
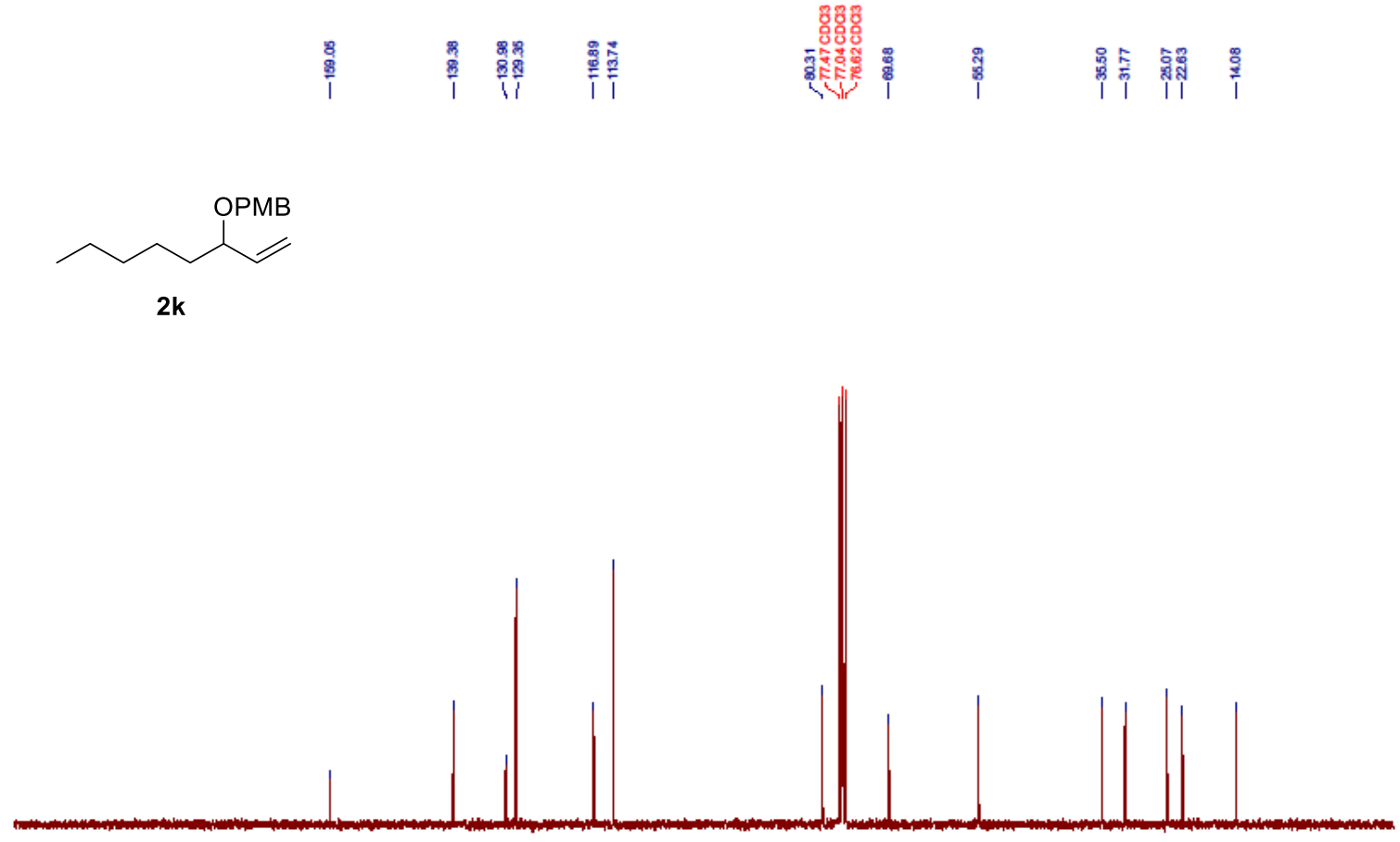

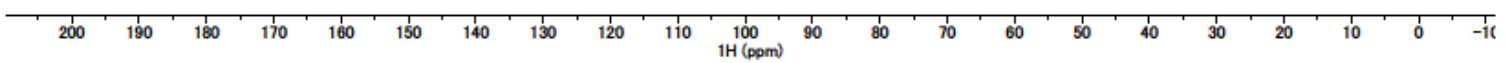


${ }^{1} \mathrm{H}$ NMR spectrum in $\mathrm{CDCl}_{3}(500 \mathrm{MHz})$

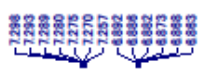

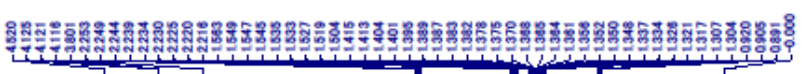
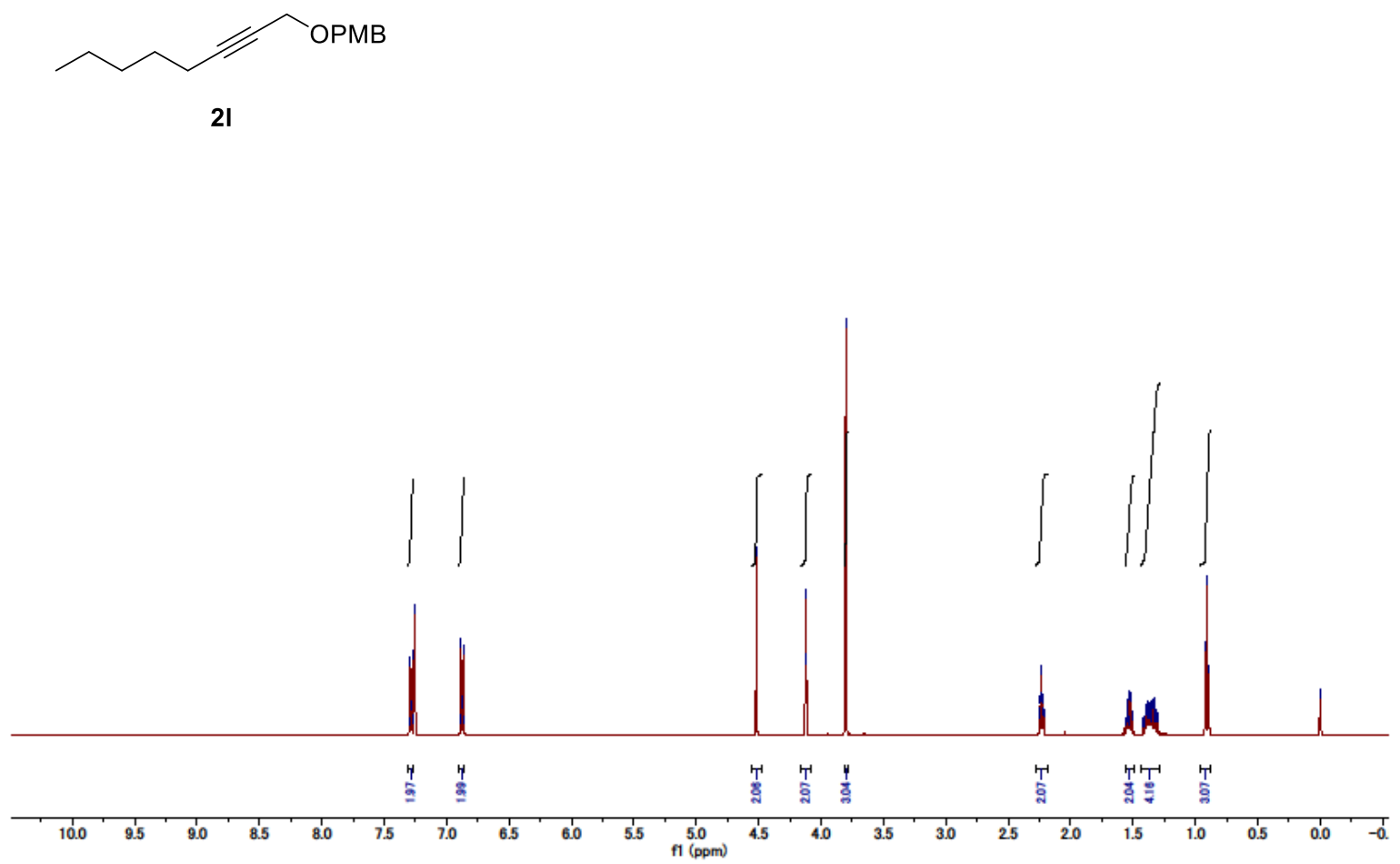

${ }^{13} \mathrm{C}$ NMR spectrum in $\mathrm{CDCl}_{3}(125 \mathrm{MHz})$
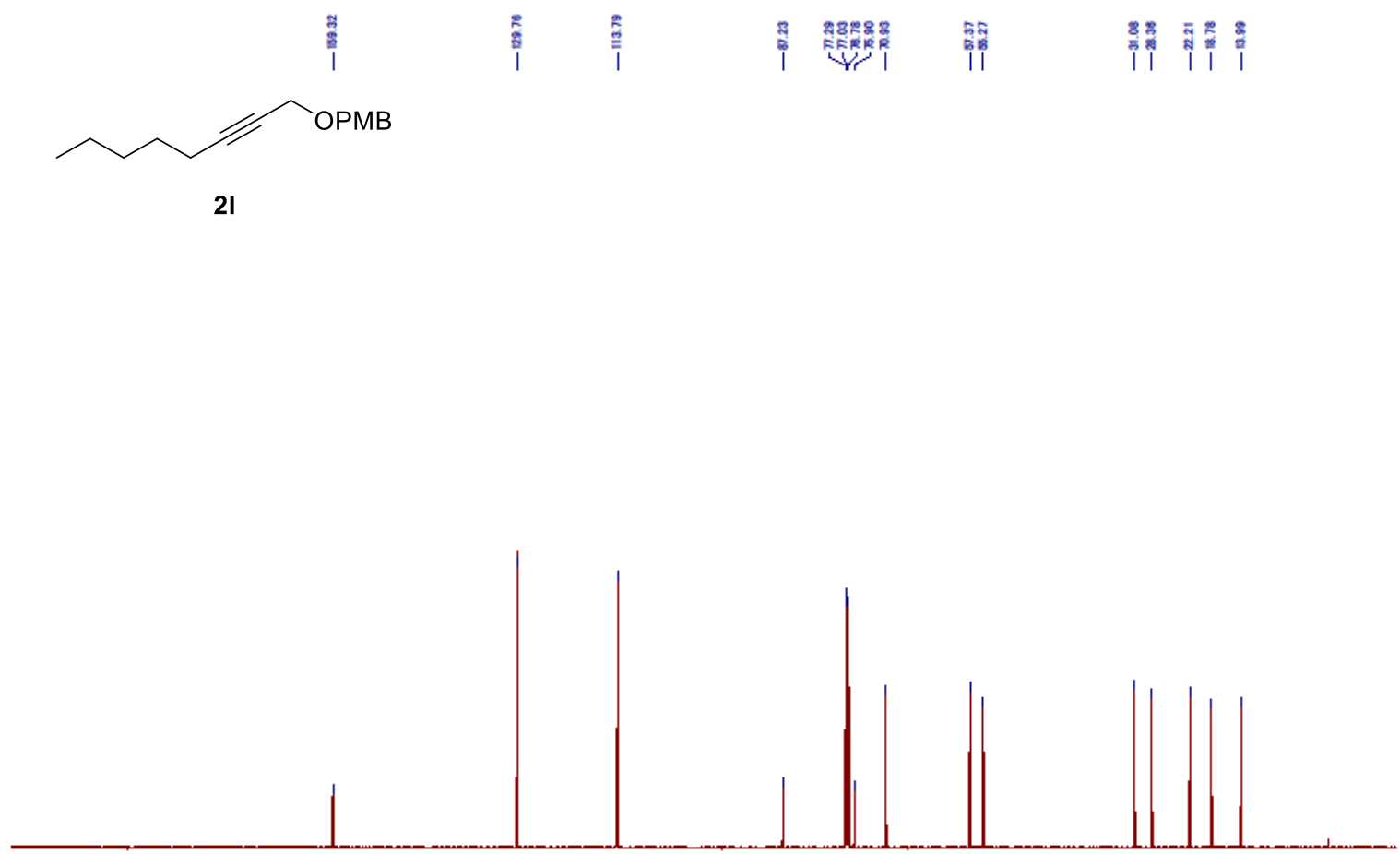

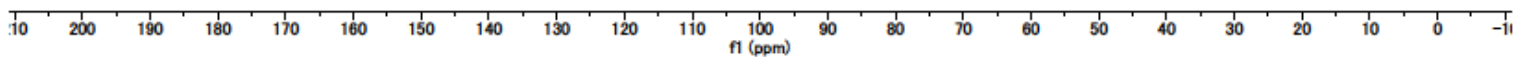


${ }^{1} \mathrm{H}$ NMR spectrum in $\mathrm{CDCl}_{3}(300 \mathrm{MHz})$

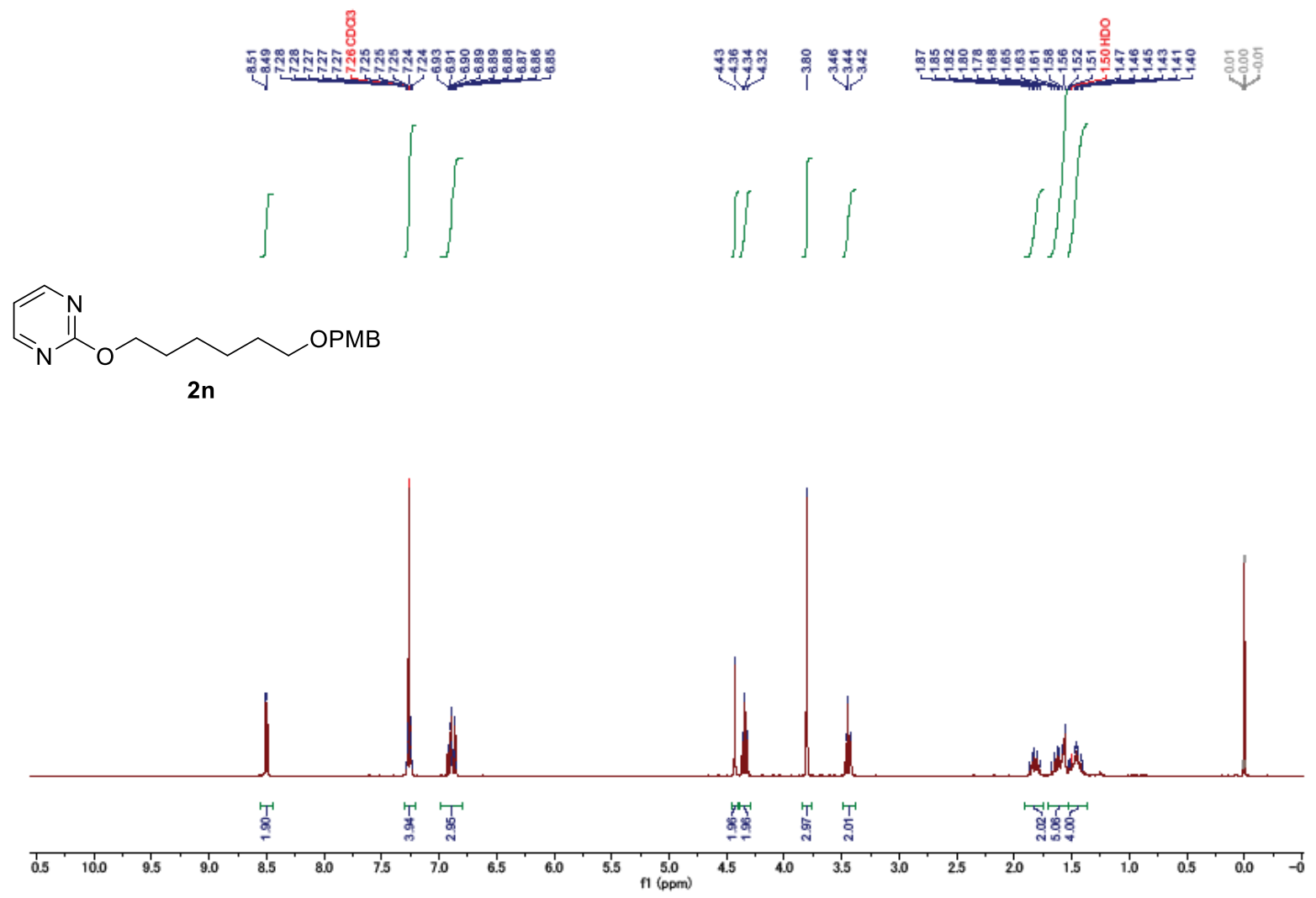

${ }^{13} \mathrm{C}$ NMR spectrum in $\mathrm{CDCl}_{3}(75 \mathrm{MHz})$

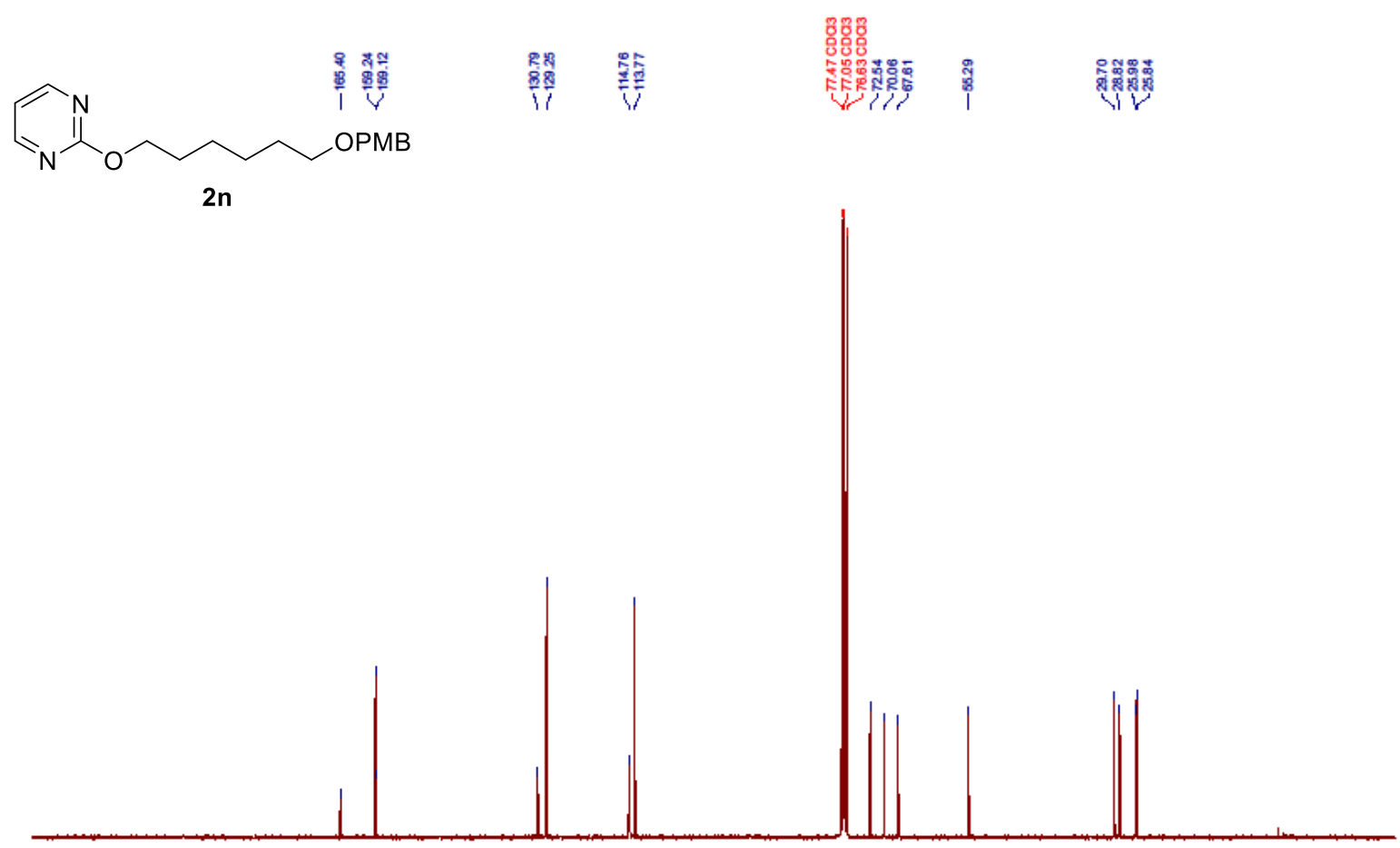

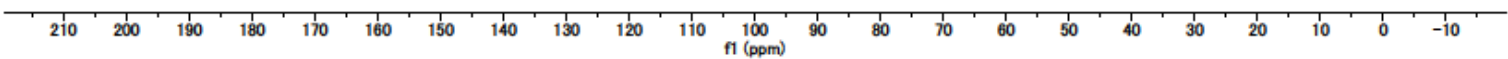


${ }^{1} \mathrm{H}$ NMR spectrum in $\mathrm{CDCl}_{3}(500 \mathrm{MHz})$

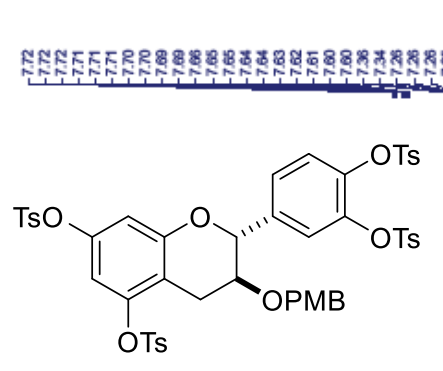

$2 p$

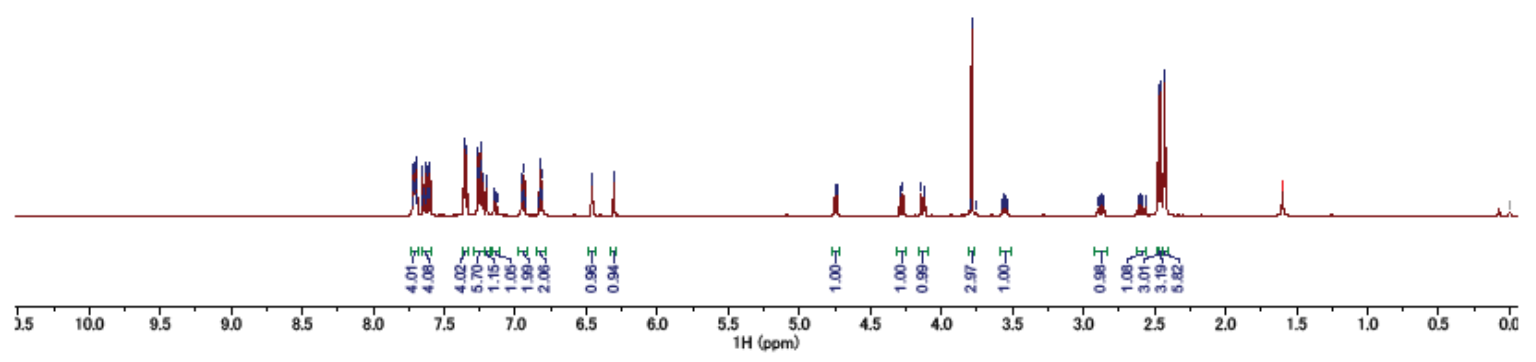

${ }^{13} \mathrm{C}$ NMR spectrum in $\mathrm{CDCl}_{3}(125 \mathrm{MHz})$

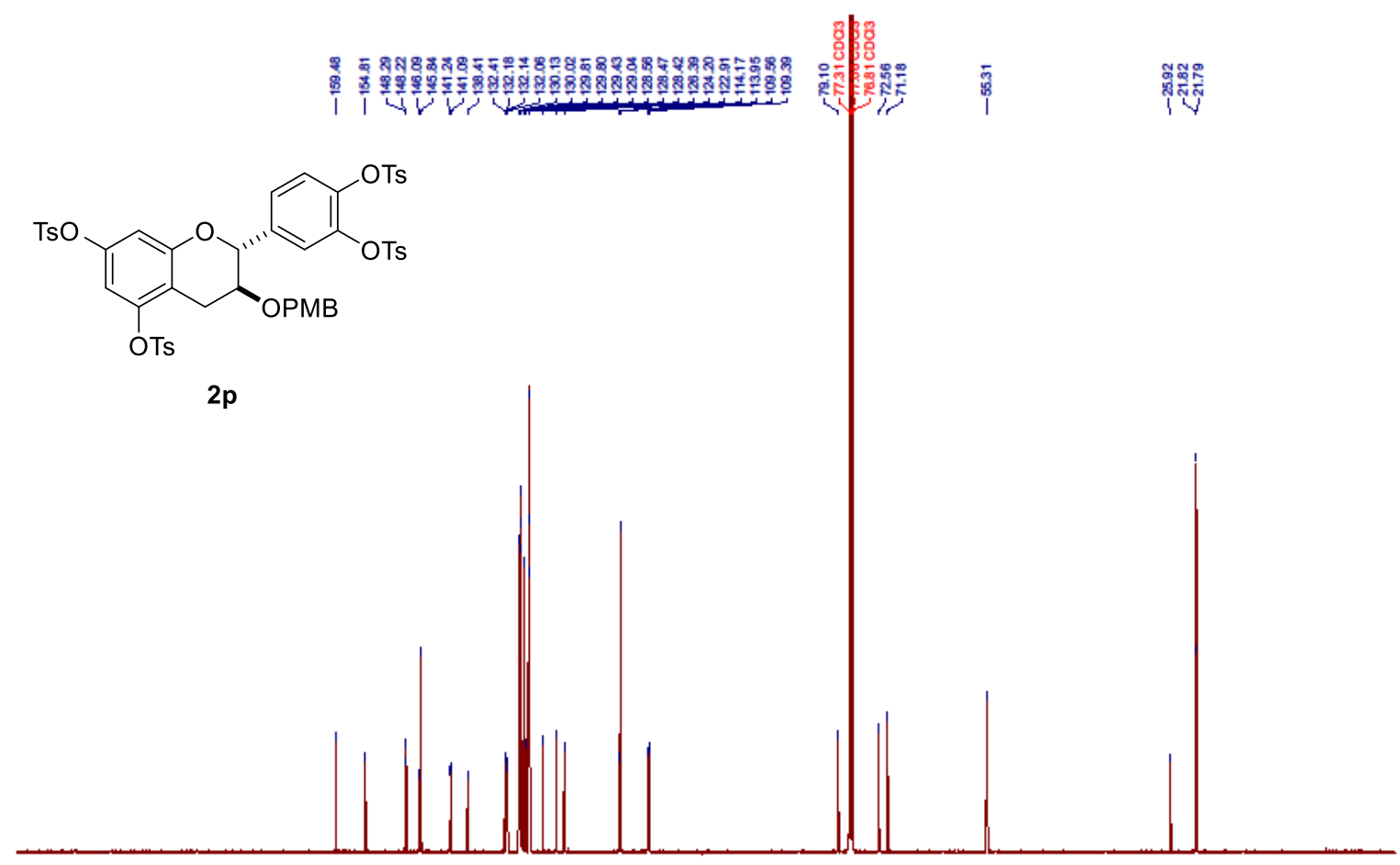

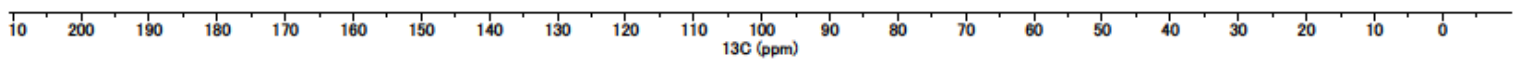


${ }^{1} \mathrm{H}$ NMR spectrum in $\mathrm{CDCl}_{3}(500 \mathrm{MHz})$
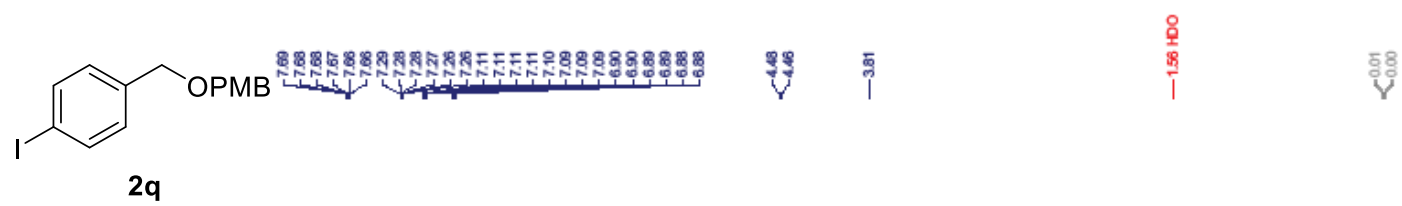

$2 q$

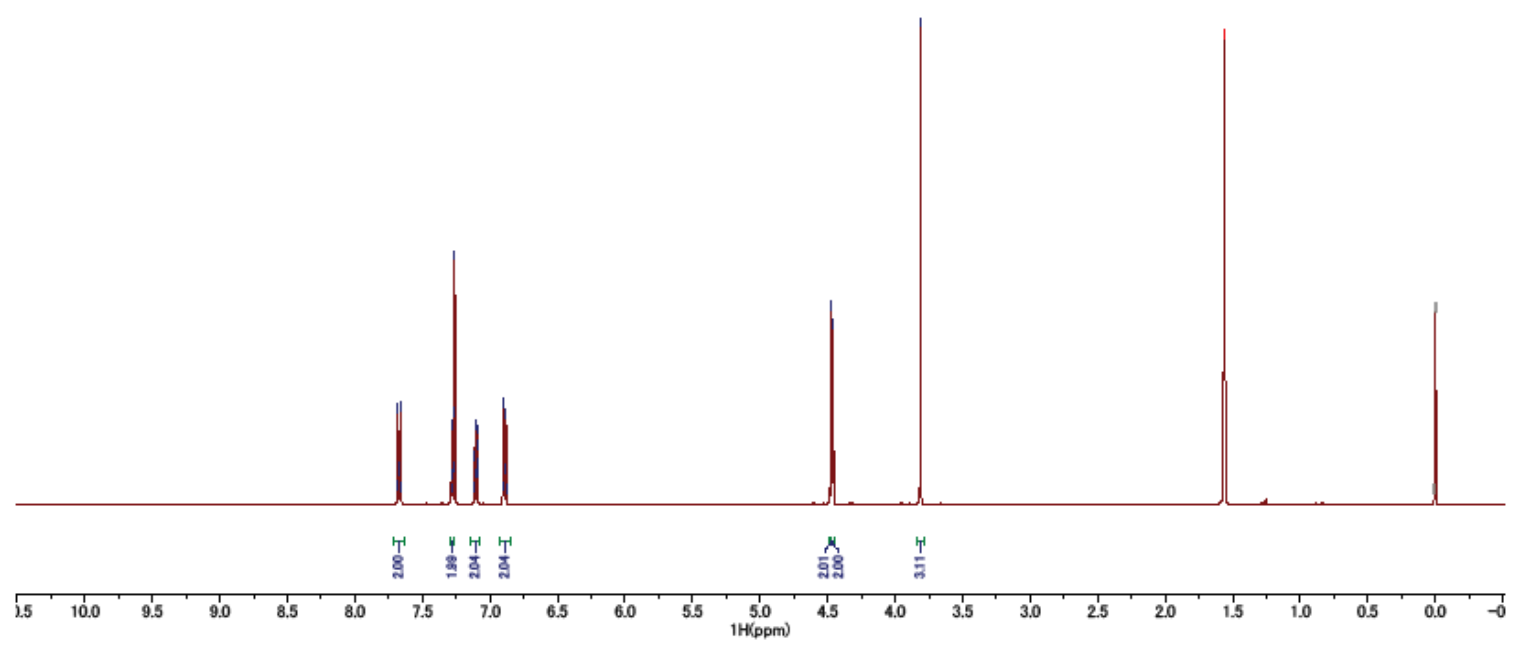

${ }^{13} \mathrm{C}$ NMR spectrum in $\mathrm{CDCl}_{3}(125 \mathrm{MHz})$
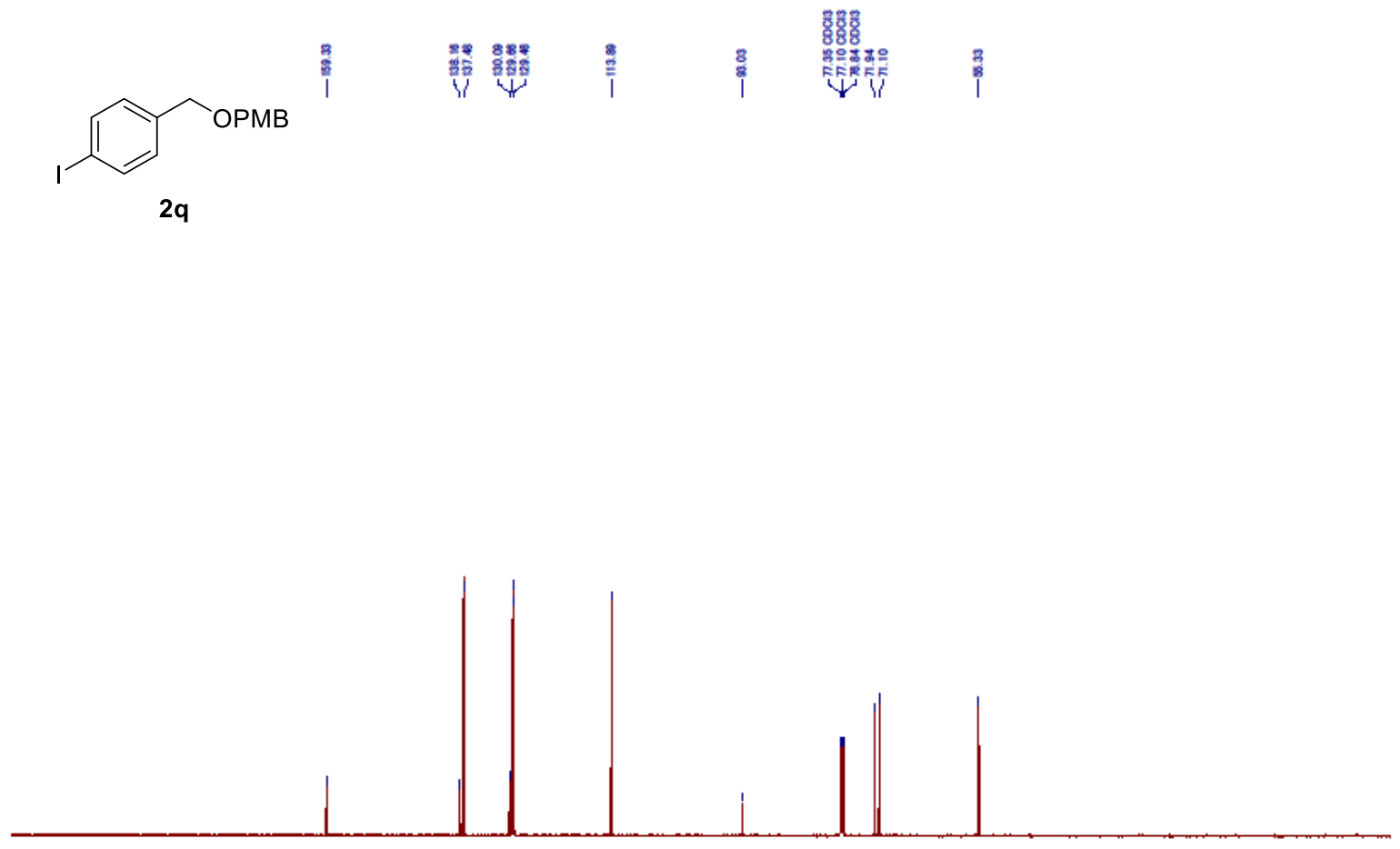

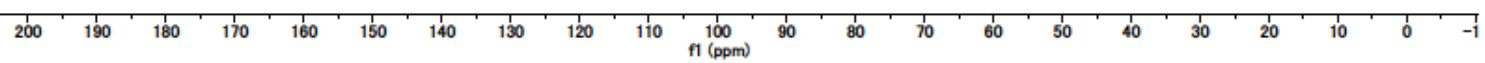


${ }^{1} \mathrm{H}$ NMR spectrum in $\mathrm{CDCl}_{3}(300 \mathrm{MHz})$

\section{g:a

$\curvearrowright \sim_{0} t_{6} \mathrm{OPMB}$

$2 u$

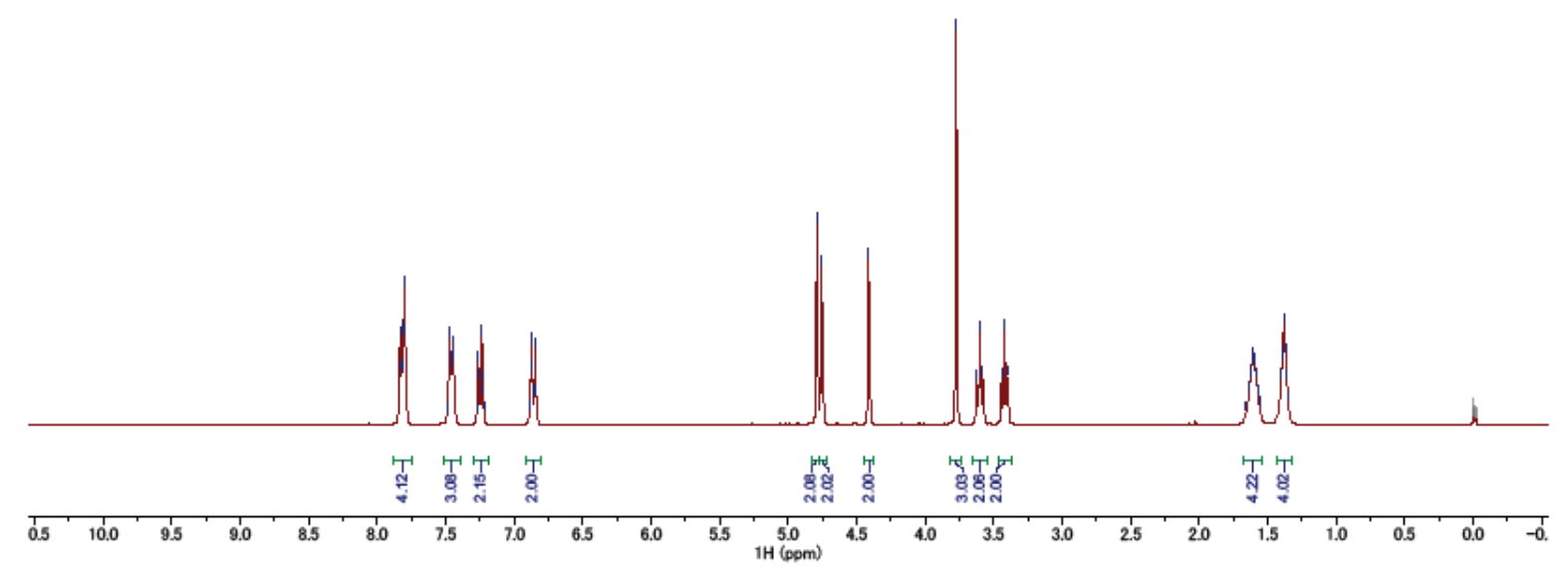

${ }^{13} \mathrm{C}$ NMR spectrum in $\mathrm{CDCl}_{3}(75 \mathrm{MHz})$

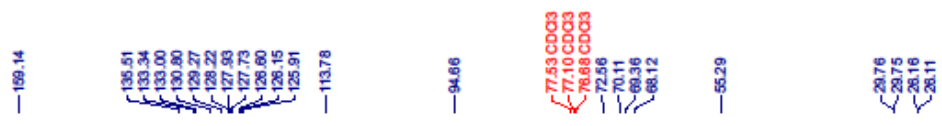

$\curvearrowright \sim_{0}+t_{0 P M B}$

2u

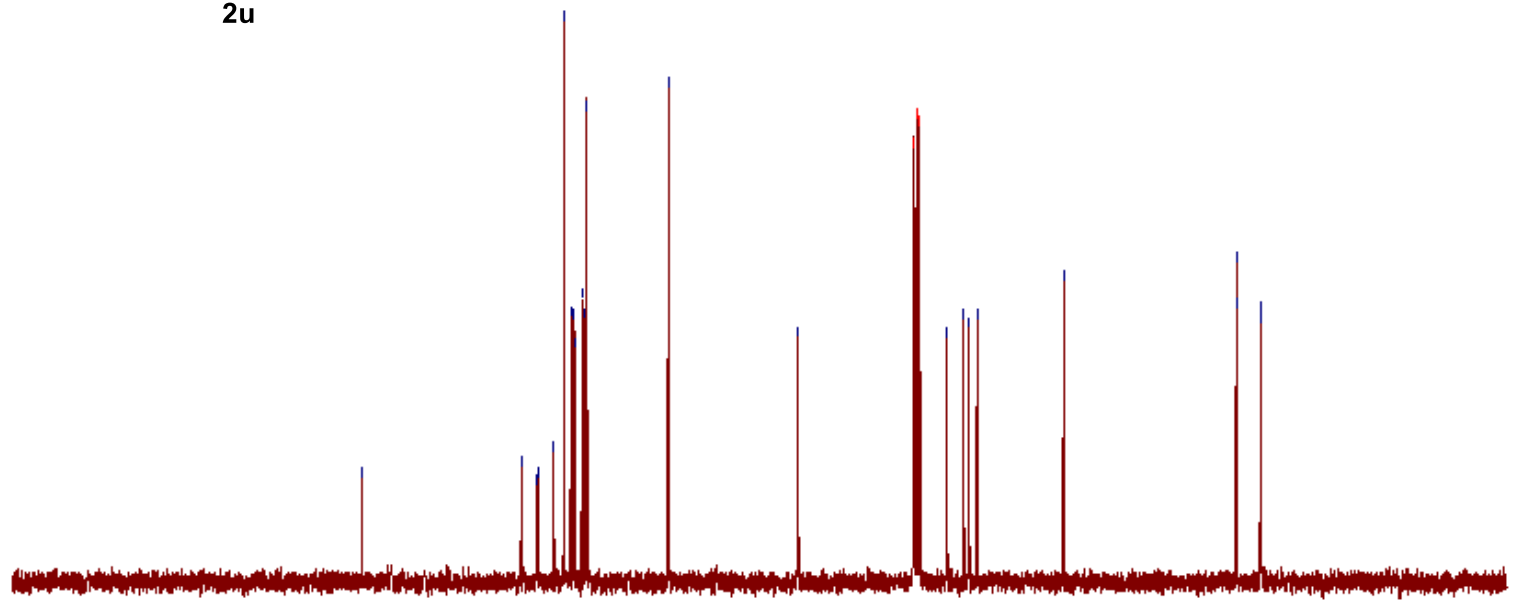

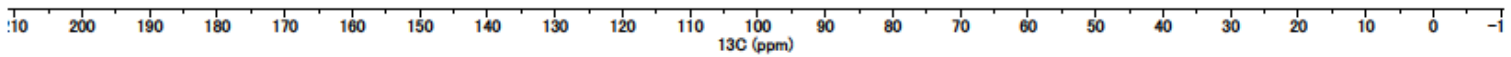


${ }^{1} \mathrm{H}$ NMR spectrum in $\mathrm{CDCl}_{3}(300 \mathrm{MHz})$

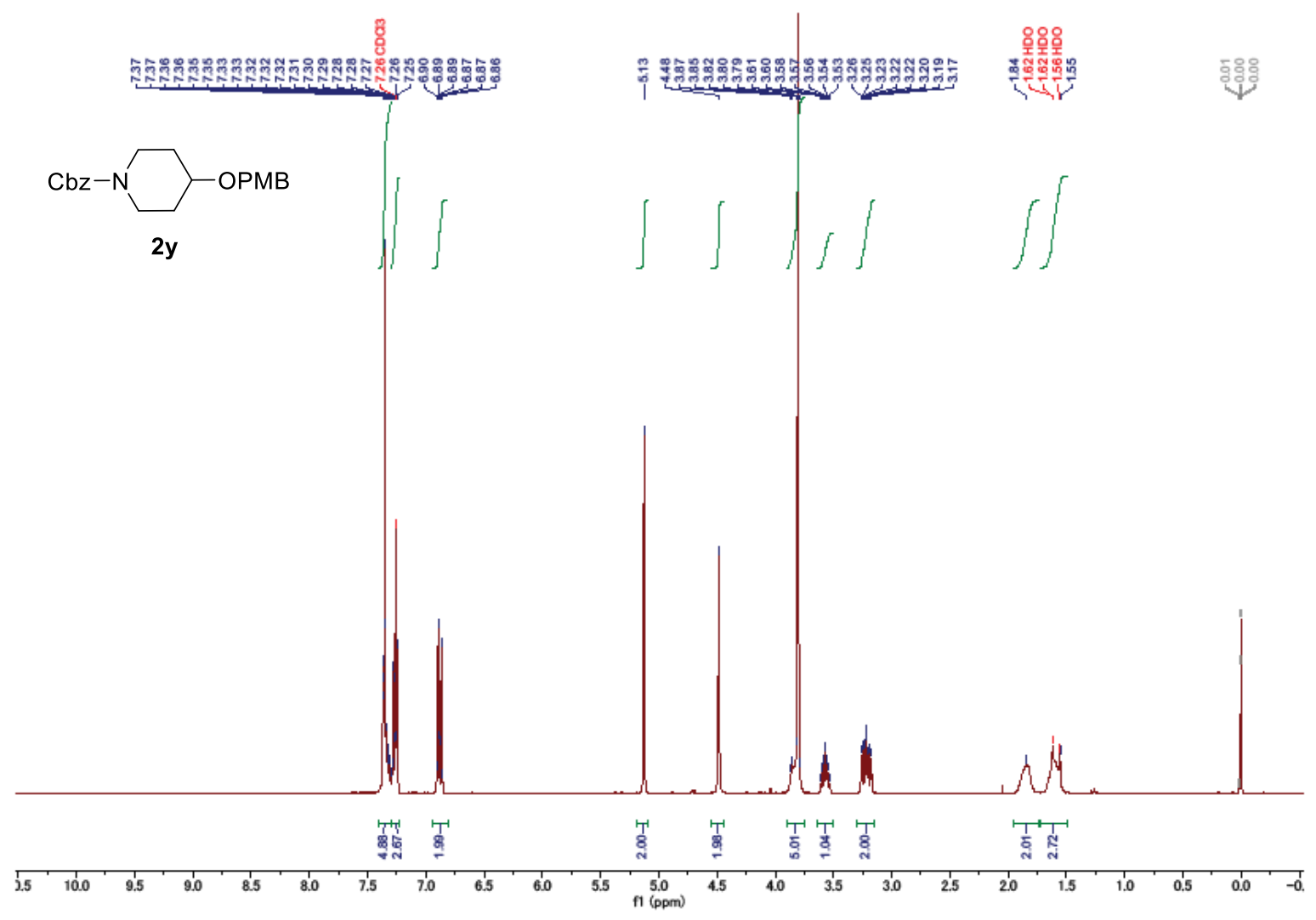

${ }^{13} \mathrm{C}$ NMR spectrum in $\mathrm{CDCl}_{3}(75 \mathrm{MHz})$

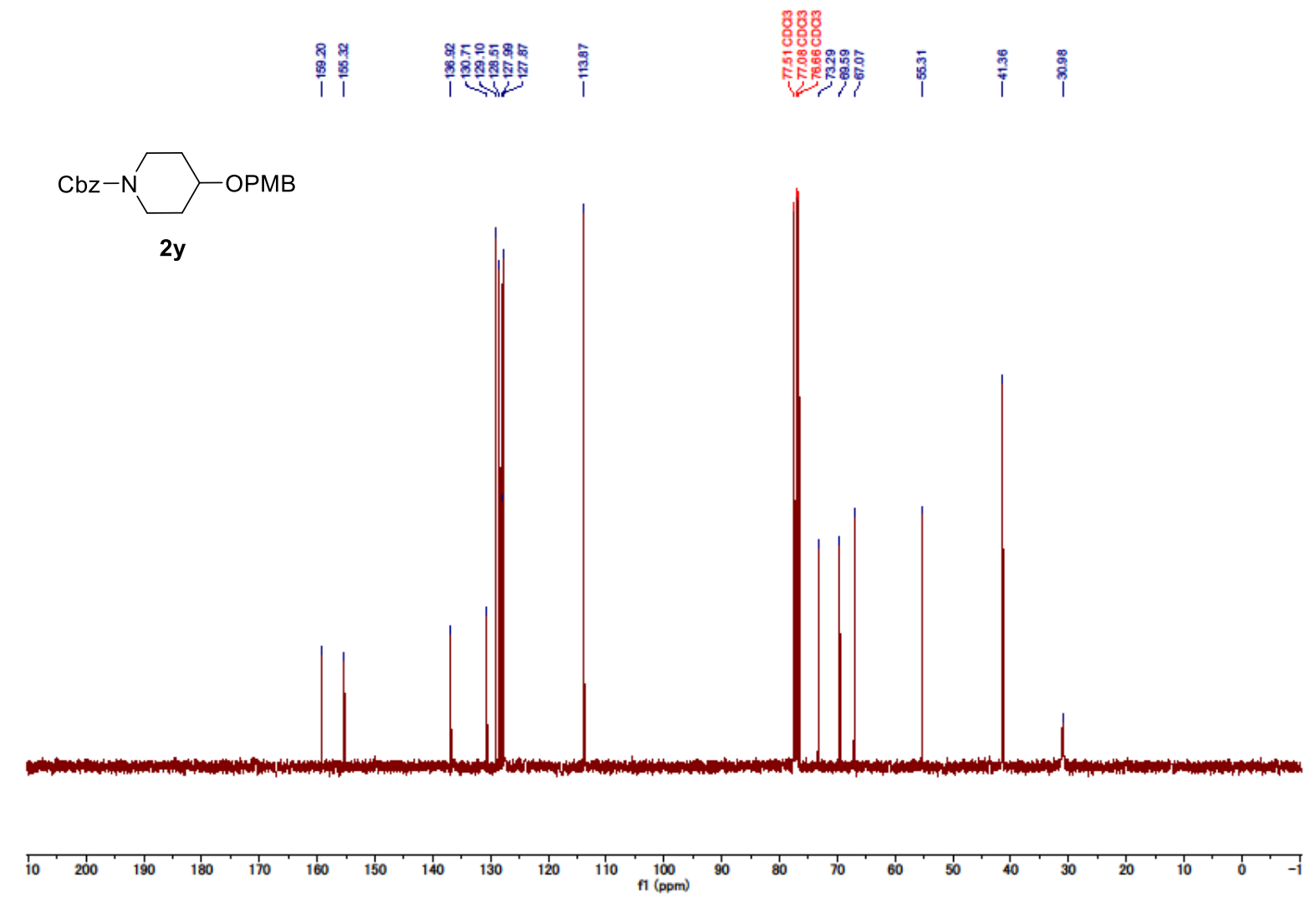


${ }^{1} \mathrm{H}$ NMR spectrum in $\mathrm{CDCl}_{3}(500 \mathrm{MHz})$
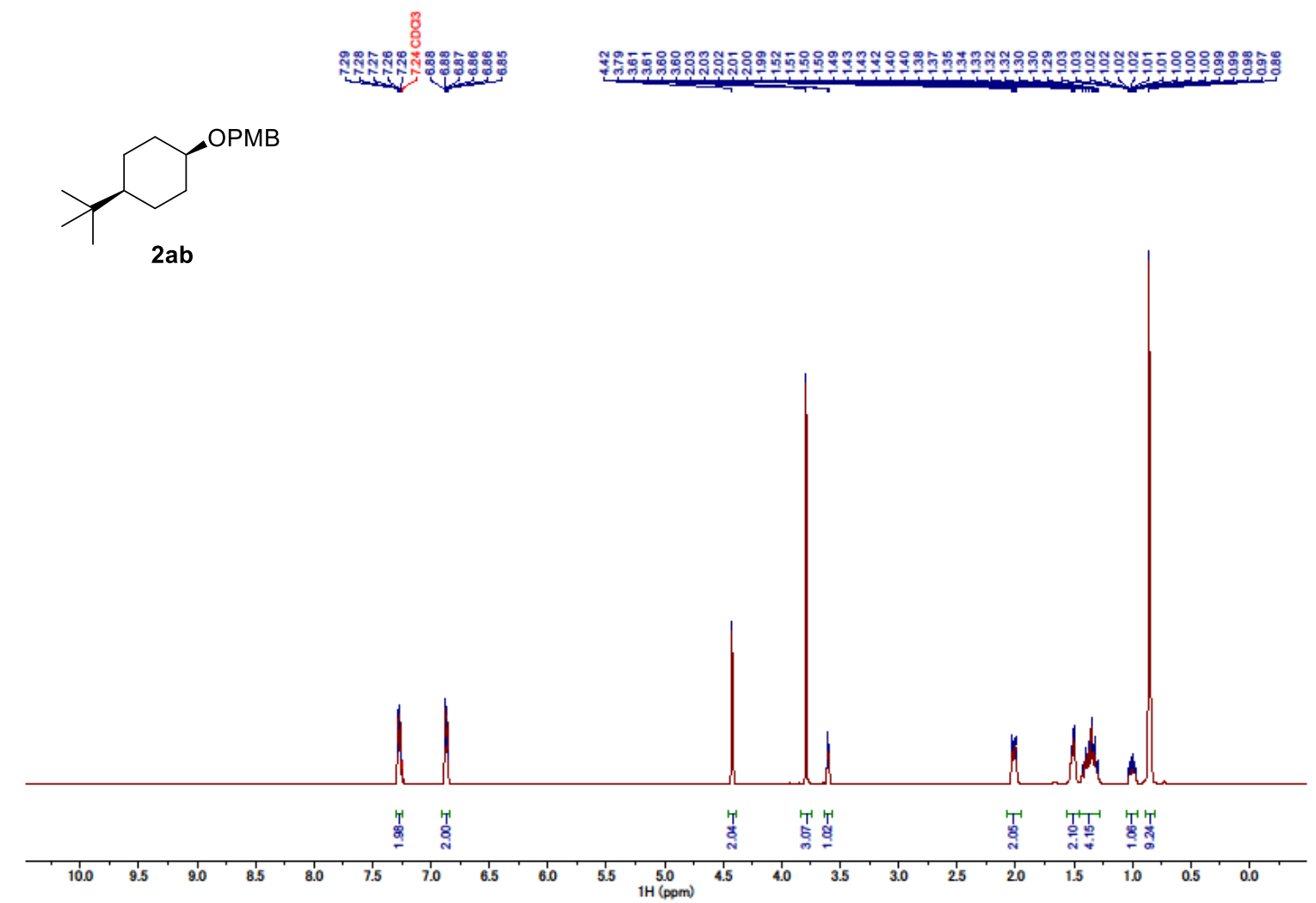

${ }^{13} \mathrm{C}$ NMR spectrum in $\mathrm{CDCl}_{3}(75 \mathrm{MHz})$

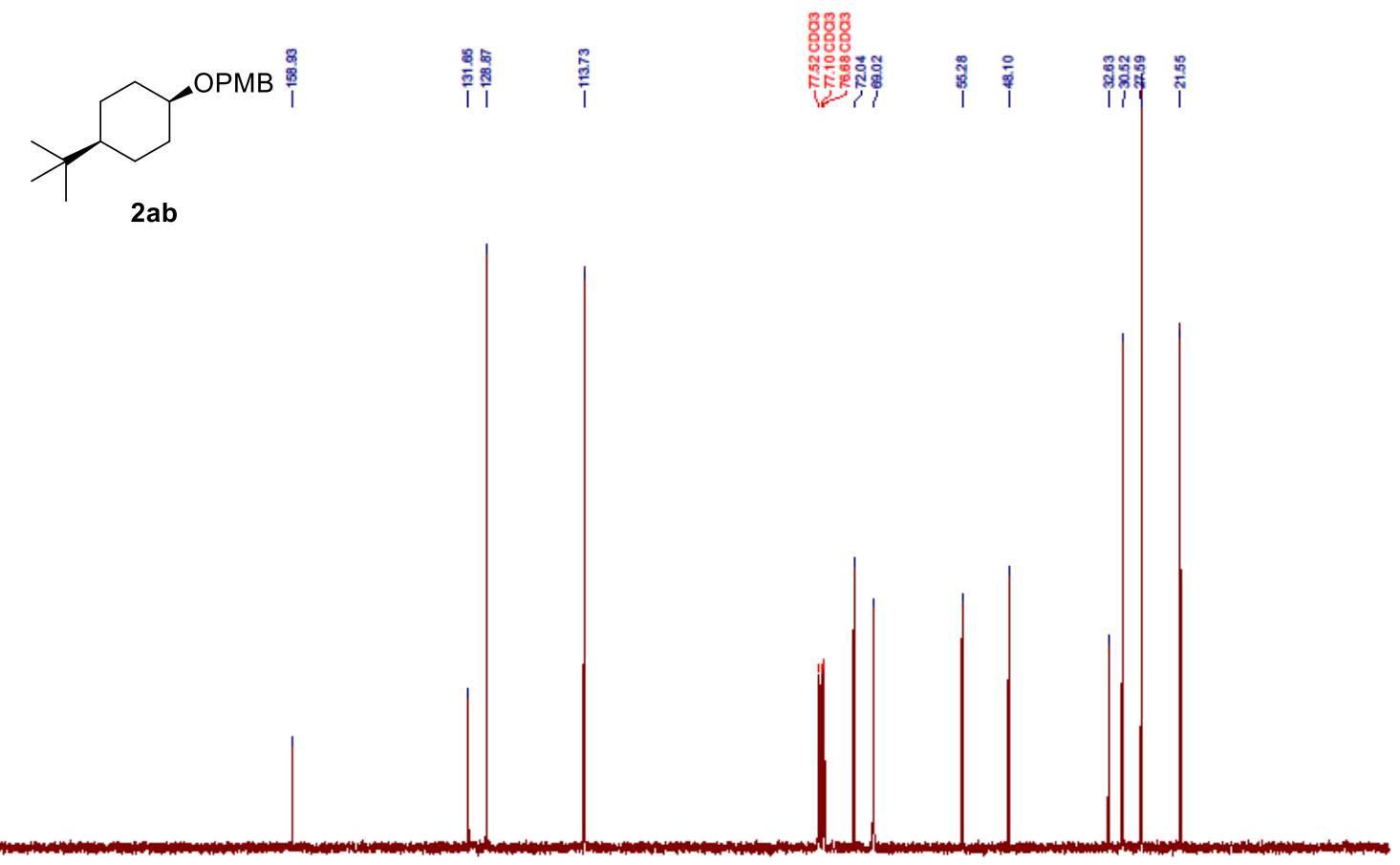

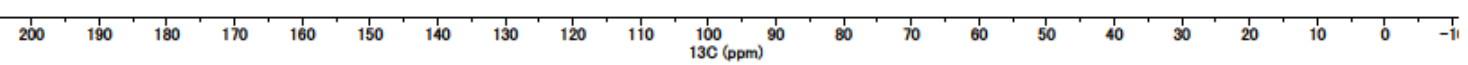


${ }^{1} \mathrm{H}$ NMR spectrum in $\mathrm{CDCl}_{3}(500 \mathrm{MHz})$

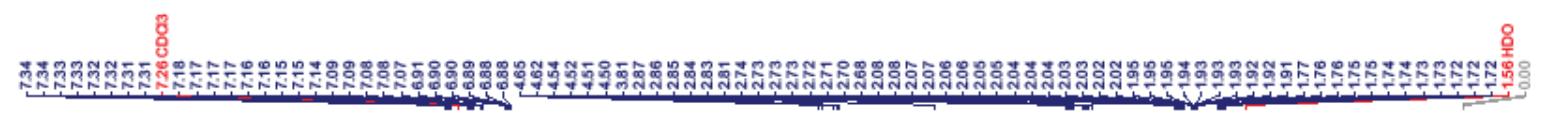<smiles>[18O]C1CCCc2ccccc21</smiles>

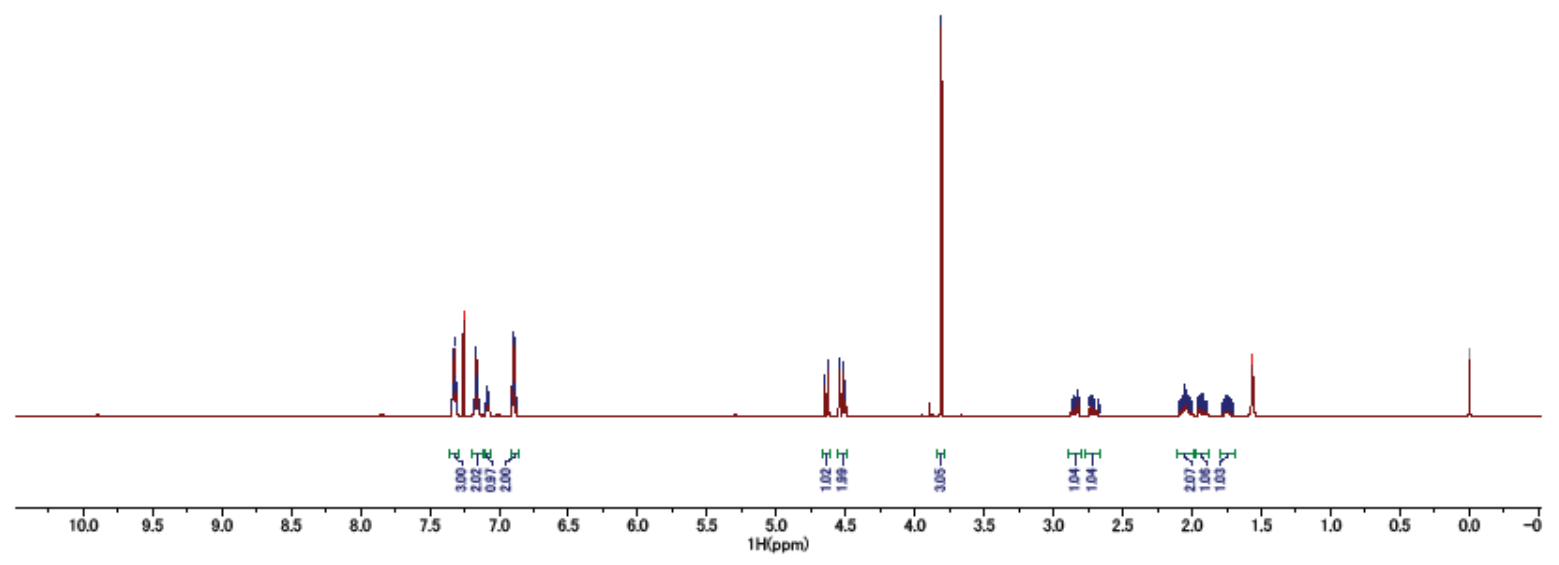

${ }^{13} \mathrm{H}$ NMR spectrum in $\mathrm{CDCl}_{3}(125 \mathrm{MHz})$
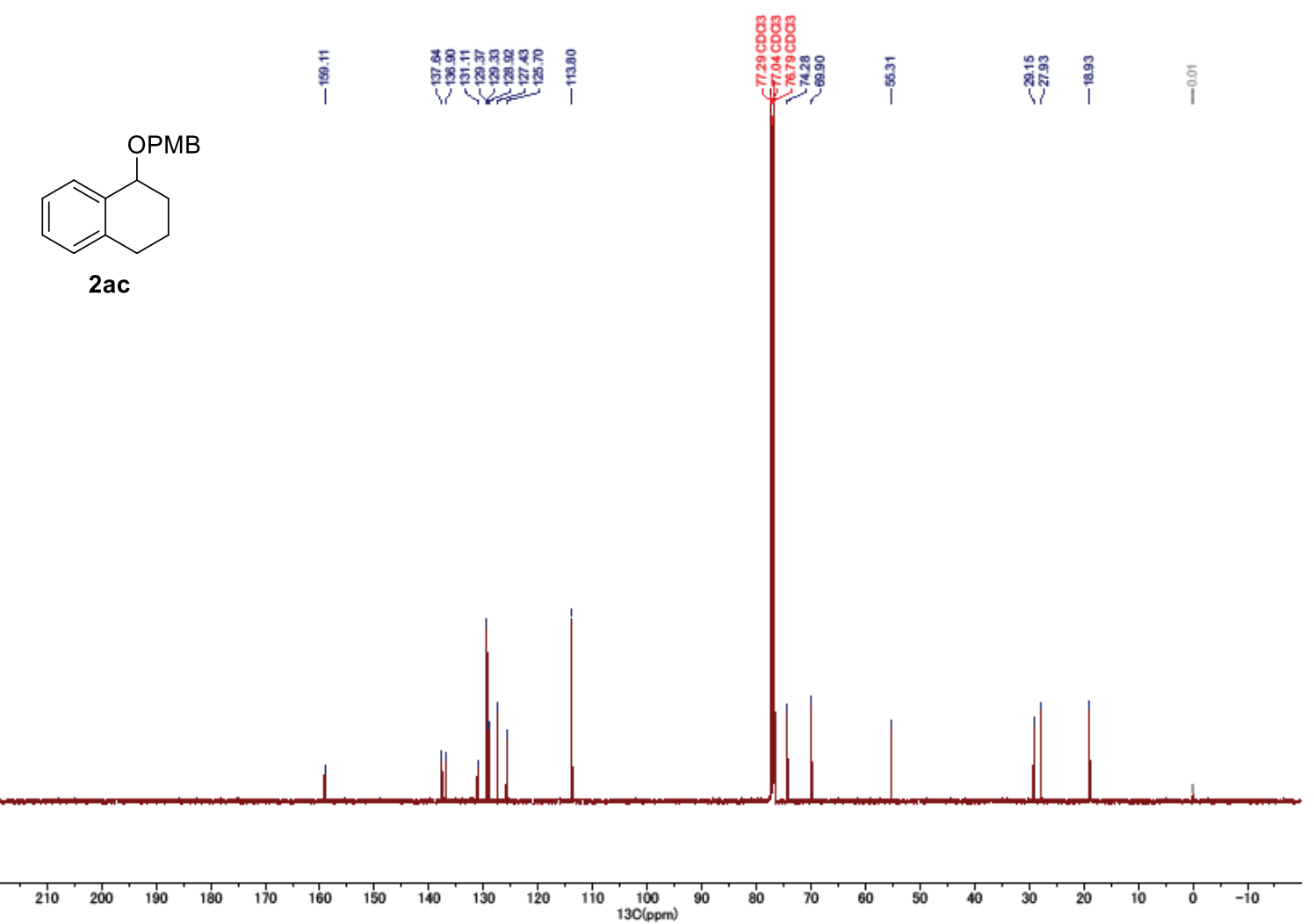
${ }^{1} \mathrm{H}$ NMR spectrum in $\mathrm{CDCl}_{3}(300 \mathrm{MHz})$

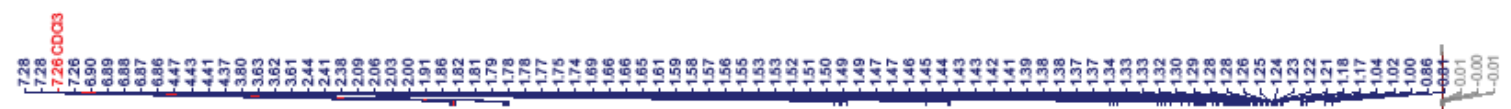

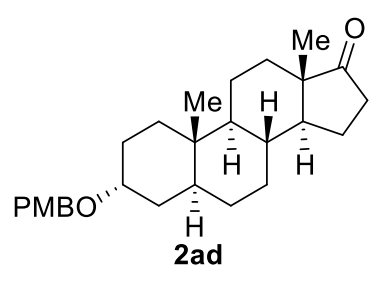

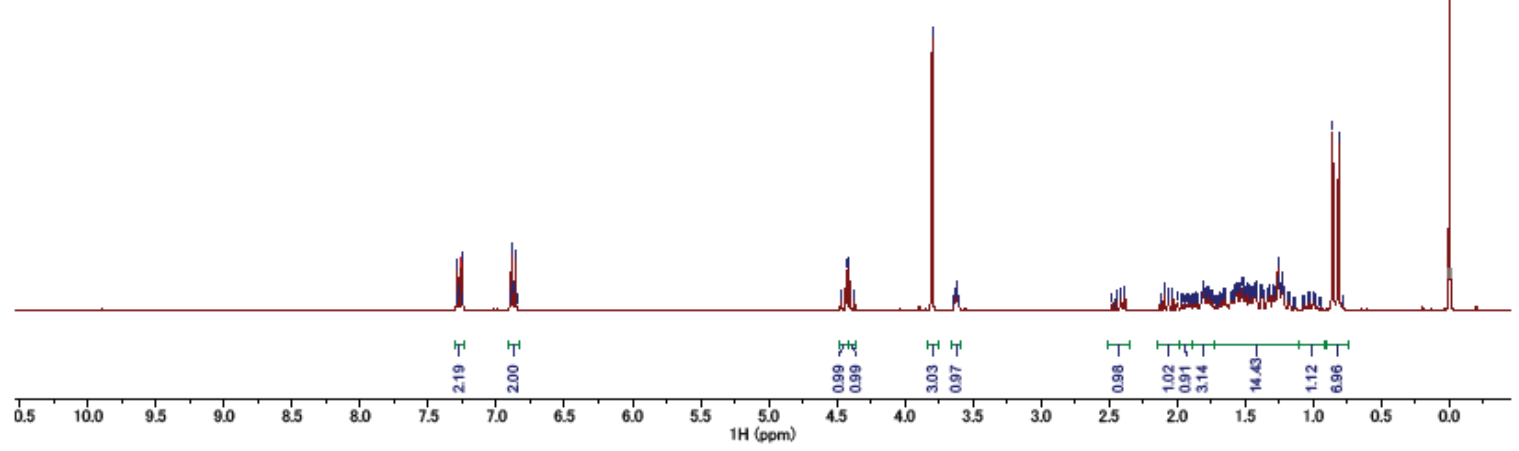

${ }^{13} \mathrm{C}$ NMR spectrum in $\mathrm{CDCl}_{3}(125 \mathrm{MHz})$
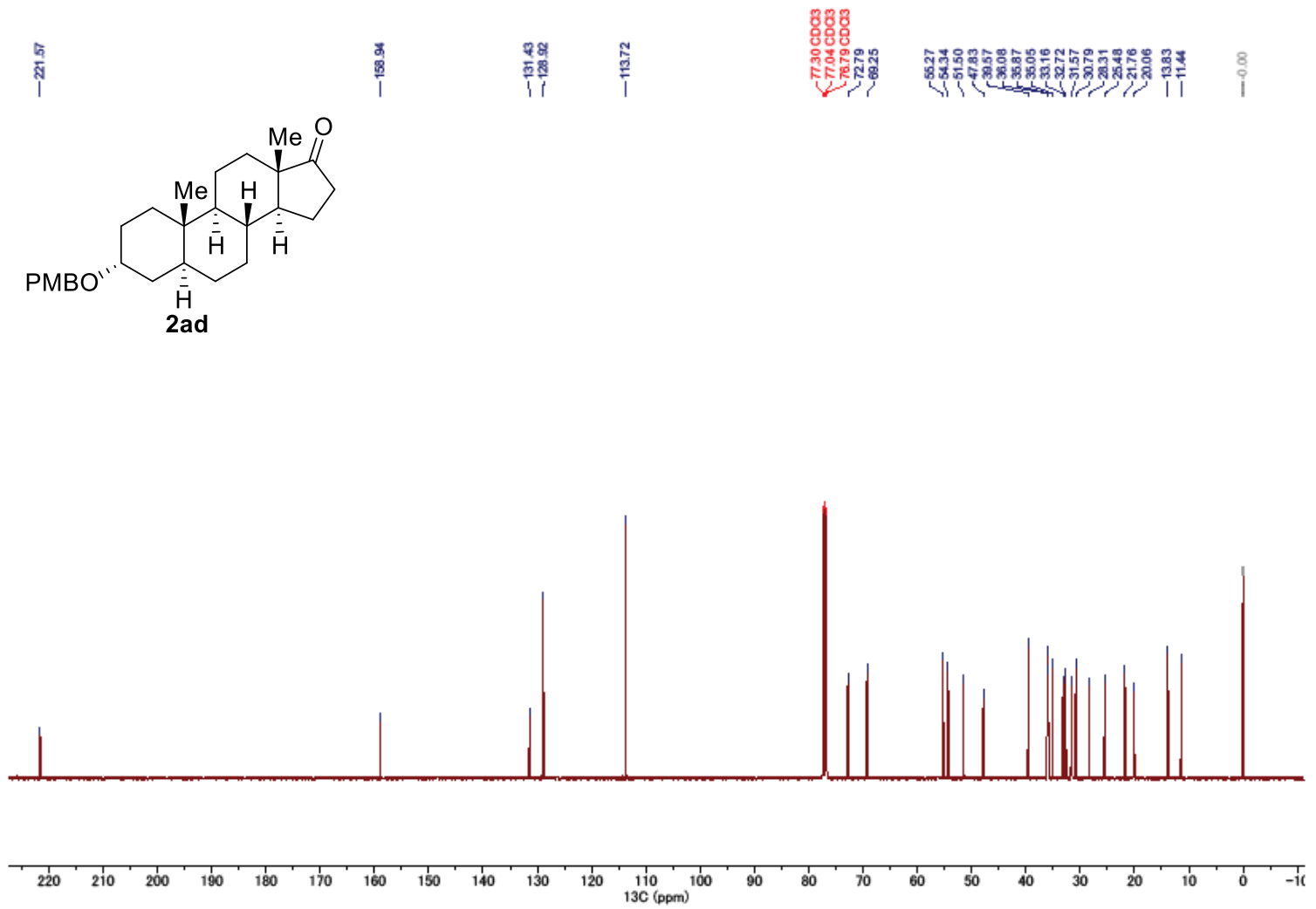
${ }^{1} \mathrm{H}$ NMR spectrum in $\mathrm{CDCl}_{3}(500 \mathrm{MHz})$
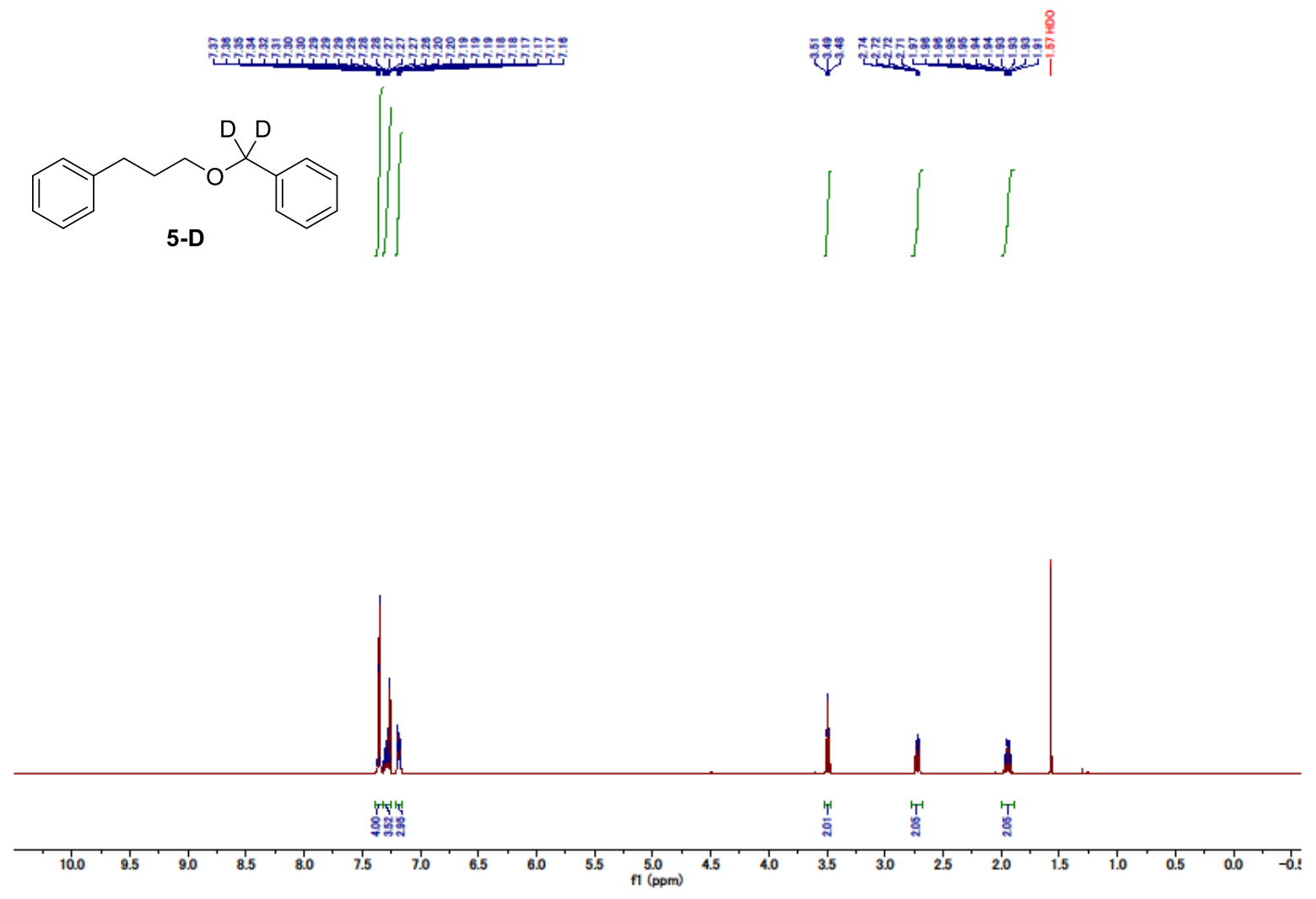

${ }^{13} \mathrm{C}$ NMR spectrum in $\mathrm{CDCl}_{3}(75 \mathrm{MHz})$

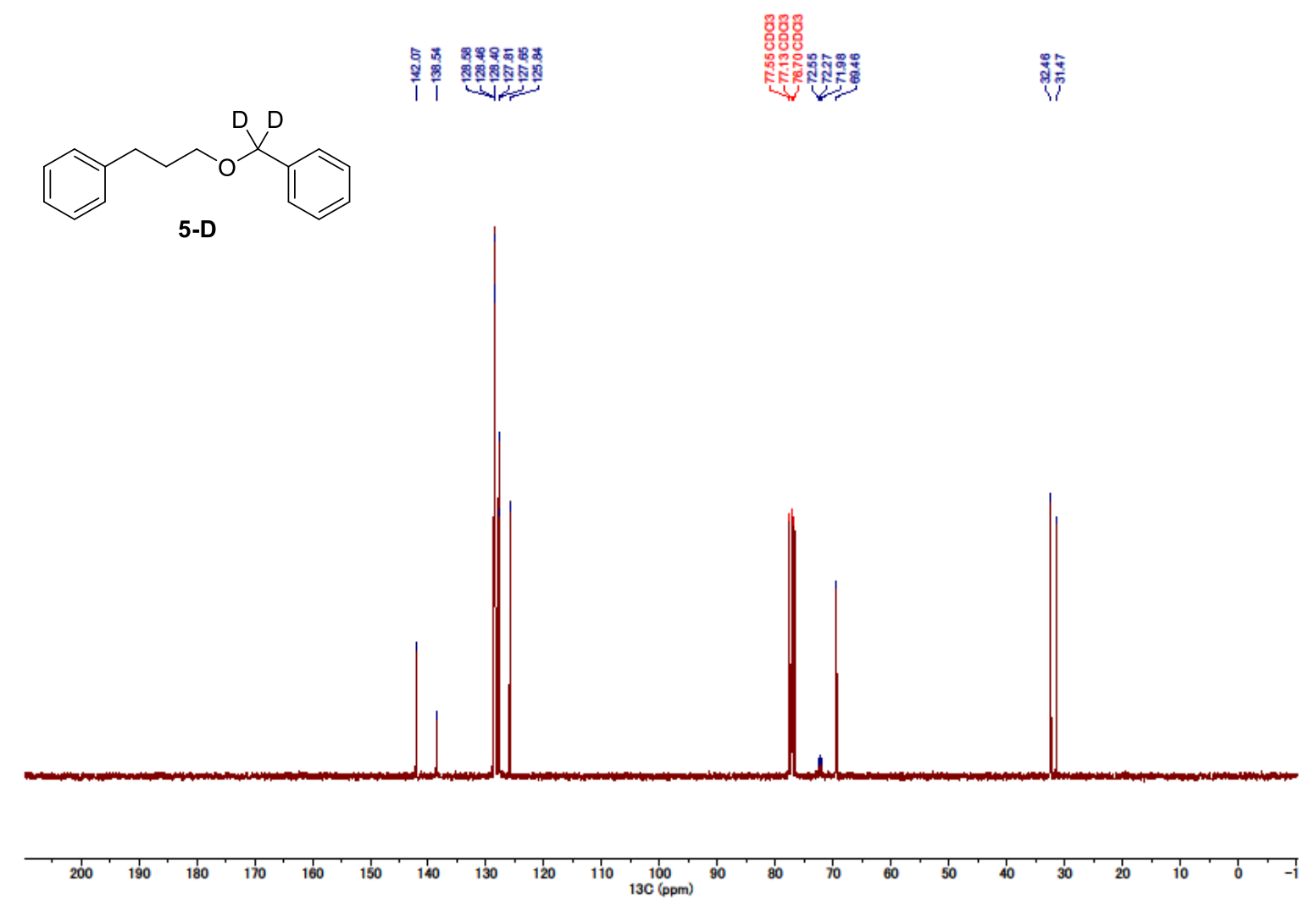


${ }^{1} \mathrm{H}$ NMR spectrum in $\mathrm{CDCl}_{3}(300 \mathrm{MHz})$

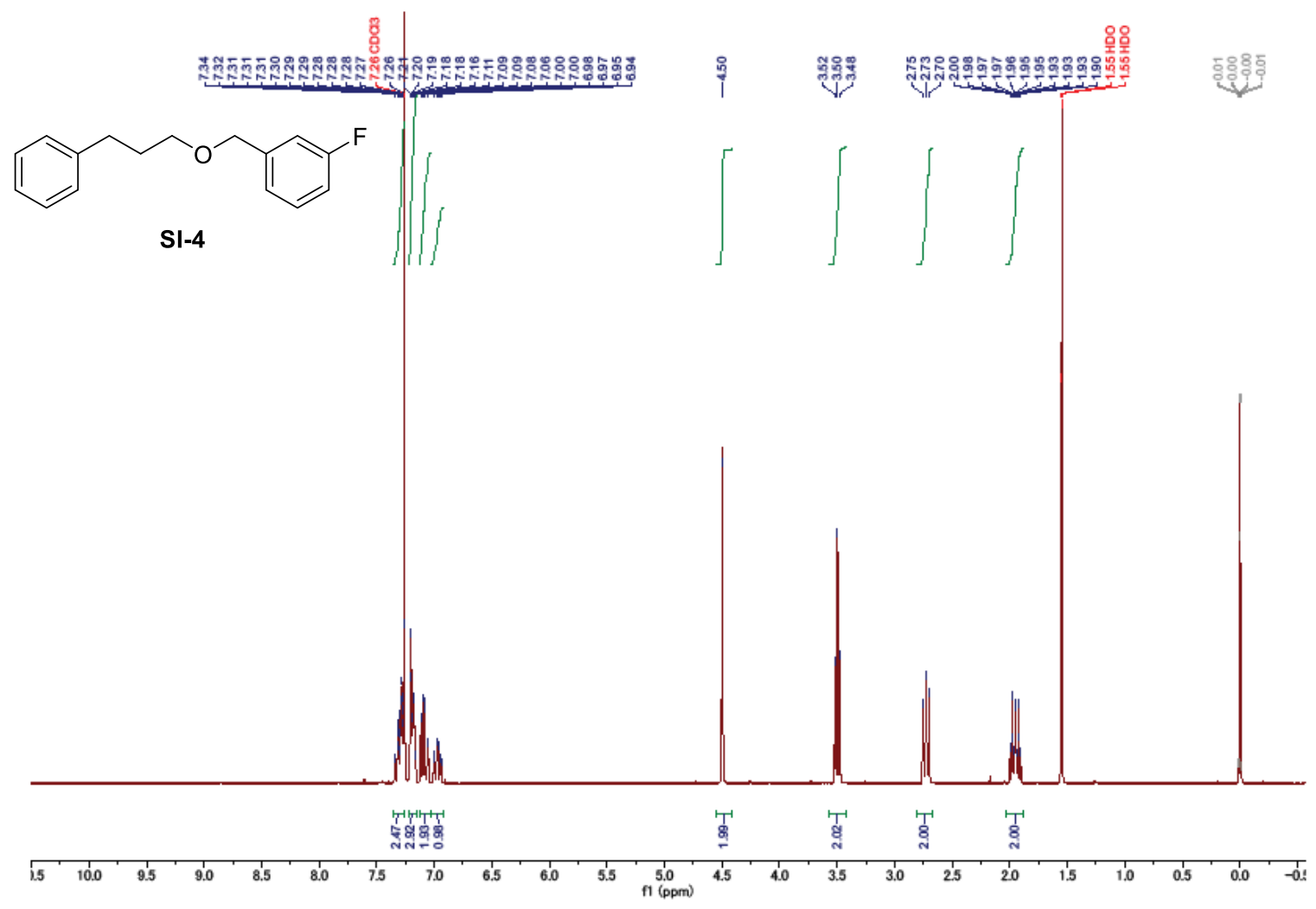

${ }^{13} \mathrm{C}$ NMR spectrum in $\mathrm{CDCl}_{3}(75 \mathrm{MHz})$
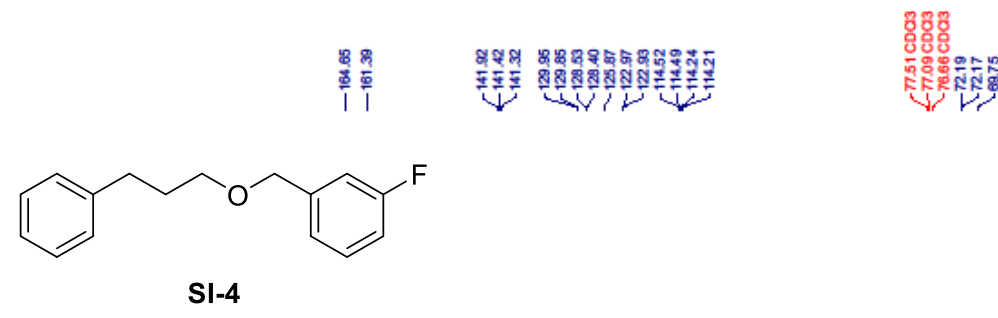

ㅇํำ

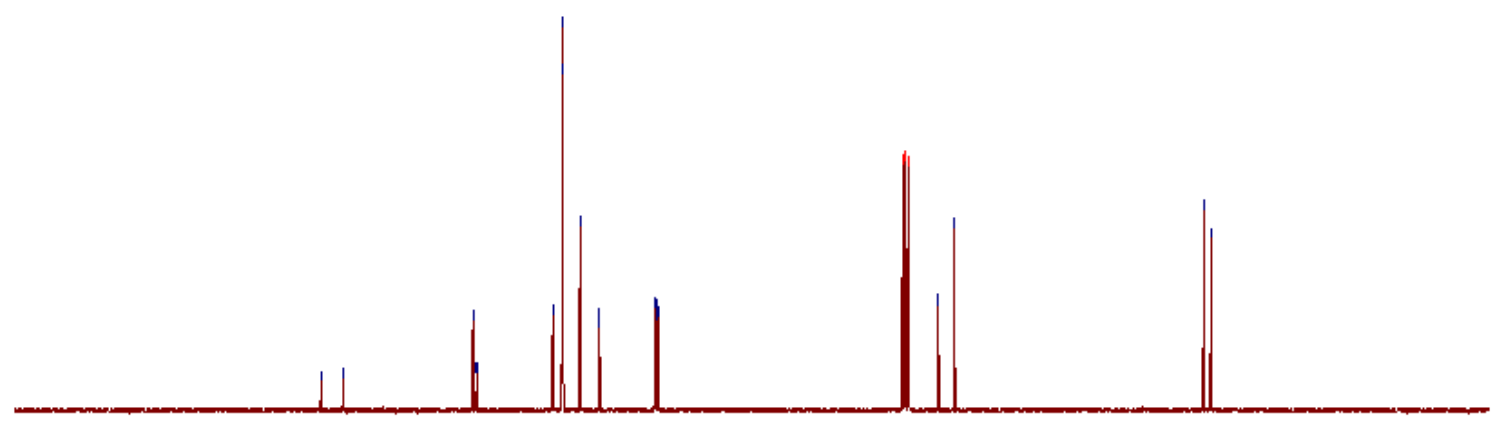

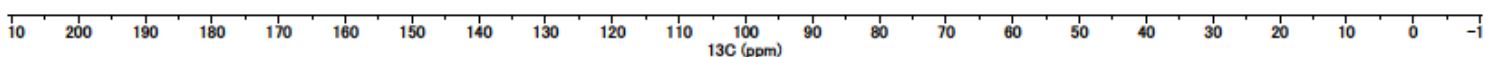

